\title{
Imagining the Age of Oil: Case Studies in British Petrocultures, 1865-1935
}

by

\author{
Ian Wereley
}

A thesis submitted to the Faculty of Graduate and Postdoctoral Affairs in partial fulfillment of the requirements for the degree of

Doctor of Philosophy

in

History

Carleton University

Ottawa, Ontario

(C) 2018, Ian Wereley 


\begin{abstract}
This dissertation investigates the cultural history of oil in Britain over a seventyyear period, between 1865 and 1935. While much has been written about the economic, political, diplomatic, geopolitical, and military aspects of oil during this timeframe, there have been few investigations into the ways that cultural factors have shaped the history of oil in Britain, a gap in the literature that this study seeks to fill. Britain was one of the first industrialized nations to make the transition to oil and in the period under consideration, everyday consumption of the commodity increased dramatically, especially in the cities, where new oil technologies for heating, illumination, and transportation became commonplace conveniences. Using understudied sources such as public lectures, cartoons, advertisements, exhibitions, and architecture, the dissertation examines the discourses of transition that were created to help Britons navigate their changing energy landscapes. It maps the complexities, opportunities, and impasses that accompanied the historical rise of oil in Britain during the late nineteenth and early twentieth centuries, and argues that the system of things that brought oil from the wellhead to the consumer was predicated on a vast constellation of ideas.
\end{abstract}




\section{Acknowledgements}

This dissertation is the product of a long and complicated journey that would not have been possible without the guidance and support of several individuals who, in one way or another, extended their valuable assistance in the preparation of this study. A dissertation has only one name on its cover, but in the following pages the reader will discover the time, energy, and ideas of many close friends and family members seeping through. It is with great pleasure that I can finally acknowledge these debts and express my gratitude to those who have been at my side from the very beginning.

I owe much to Carleton University's Department of History. It was here that I began my postsecondary career in 2006, and since then the fourth floor of Paterson Hall has been my home away from home. To my peers in the Department of History, particularly Dr. Nick Hrynyk, Dr. Nicole Marion, Jason Charbonneau, Stuart MacKay, and Meghan Lundrigan, thank you for your contributions to this research. Our shared trials and tribulations (and the many ways in which we commiserated) have forged friendships that extend well beyond the classroom. I am also indebted to my best friend and fellow Carleton alumni, David Meinen, who frequently reminded me to have fun, and to look beyond the "ends" and toward the "means" of this research project.

My supervisor and close friend, Dr. Aleksandra Bennett, has been an unflinching source of kindness, encouragement, and dedication to my research for many years. She always made time for me, day in and day out, and her tutelage has been instrumental in my development as a student, researcher, writer, and educator. She has taught me a great deal about history and what it means to be a historian. To my dear friend and dissertation committee member, Dr. Norman Hillmer, CM, a special word of thanks. I have frequently relied on you for advice and guidance on all matters academic, but it was during our regular afternoon walks that I received the most important lessons - how to select the finest pastries, and what it means to be a good Canadian. Other Carleton faculty who have fostered my interests in history include Professors Dominique Marshall, Susan Whitney, Simon Dalby, Danielle Kinsey, Chinnaiah Jangam, David Dean, and Jennifer Evans. The completion of this dissertation is also, in no small measure, thanks to the Department's beloved graduate administrator, Joan White, whose unlimited patience and knowledge were sorely needed and greatly appreciated from beginning to end.

Members of my defence committee, Dr. Ruth Sandwell, Dr. Andre Plourde, and Dr. Pamela Walker are also to be thanked for their insightful and challenging questions, and for their encouraging words for the future. Additionally, I want to express my gratitude to the numerous librarians, library staff, and archivists who have helped me locate materials crucial to the research and writing of this dissertation, particularly Frances Montgomery and Christine Taylor at Carleton's MacOdrum Library, and Joanne Burman and Peter Housego at the British Petroleum Archives.

Making this journey worthwhile has been the unconditional love and support of my wife, Camille. Her patience has been a source of inspiration while writing this dissertation, and her quiet and expertly timed words of encouragement ("you got this") have helped me to see the light at the end of what has sometimes been a very long and dark tunnel. Finally, I dedicate this dissertation to two very special people - one who has left this world, and one who has just arrived. To my mother, Janet, who has made me who I am, and to my son, Emmett, who will forever shape who I am to be. 
Table of Contents

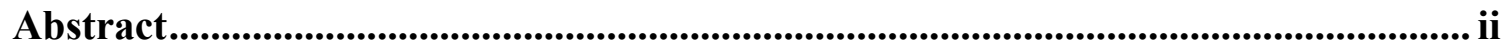

Acknowledgements ..............................................................................................

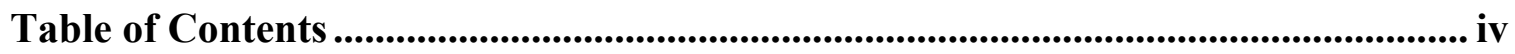

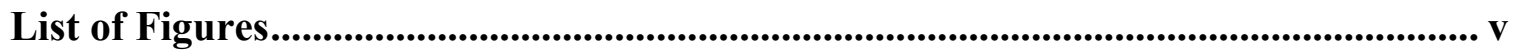

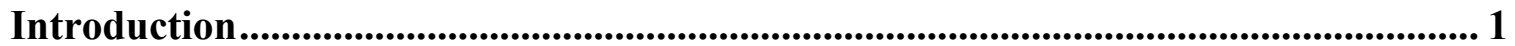

Chapter One - An Expert of the Oil Age: Sir Thomas Boverton Redwood and the Development of Oil Science in Britain, 1869-1919 ......................................................... 38

Chapter Two - Illustrating the Age of Oil: King Coal, Prince Petroleo, and the Imagination of Punch Cartoonist Leonard Raven-Hill, 1912-1933 ............................ 86

Chapter Three - Building the Age of Oil: The Anglo-Persian Oil Company and the Promotion of the Llandarcy Refinery During the Early 1920s ................................. 116 Chapter Four - Selling the Age of Oil: The British Petroleum Company and Motor

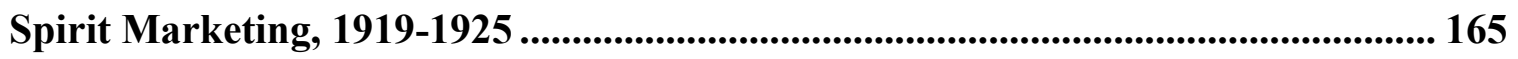

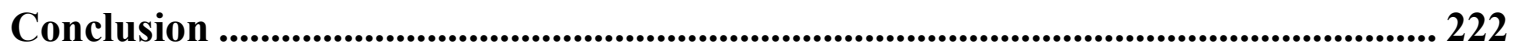

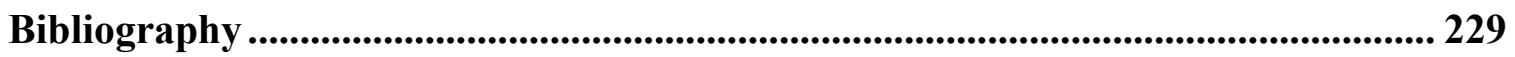




\section{List of Figures}

Figure 1: Share of primary energy consumption in the

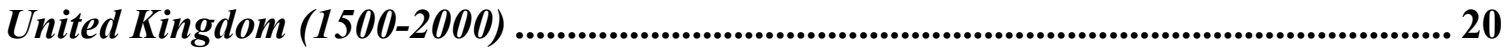

Figure 2: Sir Thomas Boverton Redwood, standing next to his namesake viscometer 73

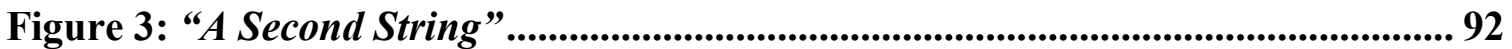

Figure 4: “Black Magic; Or, the New King Coal”....................................................... 113

Figure 5: Map of Persia showing extent of D'Arcy Concession.................................. 126

Figure 6: Illustration of Hermes and Prometheus from Llandarcy

souvenir booklet

Figure 7: “Where 'BP' Motor Spirit is Made”...................................................... 147

Figure 8: Thermos Flask fireless locomotives at the Llandarcy Refinery ................. 163

Figure 9: Residences for senior management staff, Cefn Park ................................ 163

Figure 10: A view of The Greenway, Llandarcy Village ........................................... 164

Figure 11: Illustration of Llandarcy Refinery............................................................. 164

Figure 12: BP Motor Spirit ghost sign (c. 1924), King's Cross, London ..................... 179

Figure 13: "The Sporting Spirit”'......................................................................... 187

Figure 14: “Transporting Pipe Line in Persia" ....................................................... 198

Figure 15: “150 Miles of Pipe Lines" ............................................................................. 199

Figure 16: “The Petroleum Beacon"'................................................................................. 200

Figure 17: Official Map of British Empire Exhibition, 1924, with location of BP's

Persian Khan exhibit outlined in red ................................................................... 205

Figure 18: Postcard distributed by BP staff at the Persian Khan exhibit ................... 211 



\section{Introduction}

This dissertation investigates the cultural history of oil in Britain over a seventyyear period, between 1865 and 1935. While much has been written about the economic, political, diplomatic, geopolitical, and military aspects of oil during this timeframe, there have been few investigations into the ways that cultural factors have shaped the history of oil in Britain, an absence in the literature that this study seeks to fill. Britain was one of the first industrialized nations to make the transition to oil and in the period under consideration, everyday consumption of the commodity increased dramatically, especially in the cities, where new oil technologies for heating, illumination, and transportation became commonplace conveniences. Using understudied sources such as public lectures, cartoons, advertisements, exhibitions, and architecture, the dissertation examines the discourses of transition that were created to help Britons navigate their changing energy landscapes. It maps the complexities, opportunities, and impasses that accompanied the historical rise of oil in Britain during the late nineteenth and early twentieth centuries, and argues that the system of things that brought oil from the wellhead to the consumer was predicated on a vast constellation of ideas.

The research of this dissertation is situated in the burgeoning multidisciplinary field of the Energy Humanities. ${ }^{1}$ According to Dominic Boyer and Imre Szeman, two of

\footnotetext{
${ }^{1}$ A defining feature of the Energy Humanities is its interdisciplinarity. For a sampling of the different theoretical and methodological approaches that constitute the field, see M. Paterson and S. Dalby, "Empire's Ecological Tyreprints," Environmental Politics 15 (2006): 2-3; M. Huber, Life Blood: Oil, Freedom, and the Forces of Capital (Minneapolis: University of Minnesota Press, 2013); C. Jones, Routes of Power: Energy and Modern America (Cambridge: Harvard University Press, 2014); I. Wereley, "Extracting the Past from the Present: Exotic Prizes, Empty Wilderness, and Commercial Conquest in Two Oil Company Advertisements, 1925-2012," Humanities 5, 44 (2016): 1-22. The contributions to the Energy Humanities are not limited to texts and academic research. For films, see
} 
the field's founding scholars, the primary mission of the Energy Humanities is to work to overcome the "traditional boundaries between the disciplines and between academic and applied research," and in doing so to highlight "the essential contribution that the insights and methods of the human sciences can make to areas of study and analysis that were once thought best left to the natural sciences. ${ }^{2}$ The study of petroculture is an essential component of the Energy Humanities, and recent research in this field has probed the ways in which oil conditions the images and practices that make up the fabric of everyday life. A leitmotif of the Energy Humanities is the filling in of what Frederick Buell has identified as the scholarly "gap between energy and culture."” Scholars working in the field have undertaken to demonstrate how social and cultural research on energy is crucial for understanding the nature of its impact on our lives and on our thinking. In contributing an historical lens to the Energy Humanities and its overall goal of filling the void between the hard and soft sciences, this dissertation aims to enrich scholarly understandings of the ways in which oil has been imagined in the past.

To reconstruct and explore these histories, four case studies have been developed. The first two focus on the work of individuals, namely the petroleum scientist Sir Thomas Boverton Redwood and the political cartoonist Leonard Raven-Hill. The second set of case studies centre on companies: the oil exploration and extraction firm, the Anglo-Persian Oil Company (APOC), and the motor spirit marketing firm, British Petroleum (BP). The analysis of these cases is linked by several fundamental questions:

Ursula Biemann, Black Sea Files (2005), and Josh Fox, Gasland (2010). For visual art, see Edward Burtynsky, Oil (2011), and Marina Zurkow, The Oil Show (2011).

${ }^{2}$ D. Boyer and I. Szeman, "The Rise of Energy Humanities," University Affairs, 2014. Retrieved from: www.universityaffairs.ca/opinion/in-my-opinion/the-rise-of-energy-humanities.

${ }^{3}$ F. Buell, "A Short History of Oil Cultures; or, the Marriage of Catastrophe and Exuberance," Journal of American Studies 46 (2012): 273-93. 
how was oil imagined in Britain during the late-nineteenth and early-twentieth centuries, and what major themes, stories, and ideas were involved in the shaping of these imaginaries? By engaging critically with these questions, the dissertation reveals how notions of a modern, technologically advanced, and futuristic Age of Oil fueled the development of early British petrocultures.

\section{Historiographical Considerations}

Critical engagement around questions of energy has been sparse in the humanities and social sciences. As historian Ruth Sandwell has observed, "[g]iven the enormous role that fuel, power, and energy have always played in human societies...historians' silence about energy as a discrete force or phenomenon is more than a little surprising." ${ }^{4}$ While scholars have paid some attention to hydroelectric power, nuclear power, and coal, there is a dearth of research on the history of oil, not only in Britain, but in several other oilconsuming countries as well. ${ }^{5}$ As the editors of a special 2012 volume on contemporary oil cultures in the Journal of American Studies lamented: "the humanities have not had much to say about oil." "6 Little has changed in the historiography of oil in the intervening

\footnotetext{
${ }^{4}$ R. Sandwell (ed.), Powering Up Canada: The History of Power, Fuel, and Energy from 1600 (Montreal/Kingston: McGill-Queen's University Press, 2016): 6.

${ }^{5}$ There is relatively little research on the history of oil discourses in Canada during the nineteenth and early twentieth centuries. See J. McDougall, Fuels and the National Policy (Toronto: Butterworths, 1982); P. McKenzie-Brown et al., The Great Oil Age (Calgary: Detselig, 1993); P. Sinclair, Energy in Canada (Don Mills: Oxford University Press, 2011), and R. Unger and J. Thistle, Energy Consumption in Canada in the $19^{\text {th }}$ and $20^{\text {th }}$ Centuries (Naples: Consiglio Nazionale della Ricerche, 2013); S. Penfold, "Liquid Petroleum," in R. Sandwell (ed.), Powering Up Canada (Montreal/Kingston: McGill-Queen's University Press, 2016): 274-299. There is a significant literature on early American experiences with oil. See B. Netschert and S. Shurr, Energy in the American Economy 1850-1975 (Baltimore: Johns Hopkins, 1960); A. Daum and H. Williamson, The American Petroleum Industry: the Age of Illumination 1859-99 (Westport: Greenwood, 1981); P. Sabin, Crude Politics: the California Oil Market, 1900-1940 (Berkeley: University of California Press, 2004); S. LeMenager, Living Oil: Petroleum Culture in the American Century (New York: Oxford University Press, 2014).

${ }^{6}$ R. Barrett and D. Worden, "Oil Culture: Guest Editors' Introduction,” Journal of American Studies 46, no. 2 (2012): 269.
} 
years, and the resource remains a largely hidden one. In 2017, the cultural theorist, Imre Szeman, concluded that the "characteristic mode of thinking about energy has to date been not having to think about it...especially in oil societies, the historical and social significance of energy has everywhere been hidden in plain sight."7

A major trend of recent scholarship on the subject of energy is the application of forward-looking views that attempt to predict and prepare for the social, economic, and political dimensions of future energy shifts. ${ }^{8}$ Several scholars have turned to the past in their analyses, but only to locate historical case studies that help to contextualise and prescribe remedies for present-day energy challenges. ${ }^{9}$ However, as energy historian Paul Warde has noted, a significant number of these latter discussions have focussed on the Industrial Revolution, and have "largely revolved around debates on what prompts technological change in manufacturing industry."10 This approach, when applied to the emergence of petroleum in Britain, fails to account for the many cultural reactions to oil and its associated technologies. Those scholars who have examined the history of oil have traditionally focused on its production and trade, or on the economic, industrial, and geopolitical aspects of the resource. According to Philippe Le Billon, a significant proportion of the scholarship on oil frames the subject using simplistic binaries - "as loot

\footnotetext{
${ }^{7}$ I. Szeman, "On the Energy Humanities: Contributions from the Humanities, Social Sciences, and Arts to Understanding Energy Transition and Energy Impasse," SSHRC Knowledge Synthesis Grant (KSG), Energy and Natural Resources (May 2016): 8.

${ }^{8}$ For examples, see A. Giebelhaus, et al. (eds.), Energy Transitions: Long-Term Perspectives (Boulder: Westview, 1981); B. Podobnik, "Toward a Sustainable Energy Regime: a Long-Wave Interpretation of Global Energy Shifts," Technological Forecasting and Social Change 62 (1999): 155-172; C. Cleveland (ed.), Encyclopedia of Energy (Amsterdam: Elsevier, 2004).

${ }^{9}$ J. Pratt, "The Petroleum Industry in Transition: Antitrust and the Decline of Monopoly Control in Oil," Journal of Economic History 40, no.4 (1980): 815-837; M. Melosi, Coping with Abundance: Energy and Environment in Industrial America (New York: Knopf, 1985); J. Pratt, Exxon: Transforming Energy, 19732005 (Austin: University of Texas Press, 2013).

${ }^{10}$ P. Warde, Energy Consumption in England and Wales, 1560-2000 (Rome: Consiglio Nazionale delle Ricerche, 2007): 14-15.
} 
or as military strategy." 11 A large body of scholarship in the 1950s on the rise of energy nationalisms, particularly in the Middle Eastern countries of Iraq, Kuwait, Saudi Arabia, and Iran, published in the West, employs these binaries. ${ }^{12}$ Themes of war and conflict run throughout the critical mass of research on the energy crises of the 1970s, and the shifting geopolitical landscapes that defined the decade. ${ }^{13}$

More recent studies of oil in Britain have pursued three general avenues of investigation: explaining the composition and geographical origins of oil; describing how oil is used in its many applications, and identifying the political, economic, scientific, and military repercussions that flow from its consumption. ${ }^{14}$ Several historians have explored various aspects of Britain's domestic and international oil policies, and the early relationships that were formed between the government, oil companies, and producer states at the beginning of the twentieth century. ${ }^{15}$ Marian Kent's Oil and Empire,

\footnotetext{
${ }^{11}$ P. Le Billon, "Resources," in K. Dodds et al. (eds), The Ashgate Research Companion to Critical Geopolitics (Farnham: Ashgate, 2013): 291.

${ }^{12}$ On the nationalisation of oil in the Middle East during the 1950s, see N. Kemp, Abadan (London: Allan Wingate, 1953); S. Longrigg, Oil in the Middle East (London: Oxford, 1954); H. Mielche, Lands of Aladdin (London: William Hodge, 1955); L. Elwell-Sutton, Persian Oil (London: Lawrence \& Wishart, 1955); W. Mineau, The Go Devils (London: Cassell, 1958).

${ }^{13}$ J. Laxer, Canada's Energy Crisis (Toronto: James Lorimer, 1975); P. Foster, Blue-Eyed Sheiks: The Canadian Oil Establishment (Toronto: Totem, 1977); D. Yergin \& M. Hillenbrand (eds.), Global Insecurity: a Strategy for Energy and Economic Renewal (Boston: Houghton Mifflin, 1982); E. Kapstein, The Insecure Alliance: Energy Crises and Western Politics since 1944 (New York: Oxford University Press, 1990); M. Adelman, The Genie Out of the Bottle: World Oil Since 1970 (Cambridge: MIT Press, 1995); K. Merrill, The Oil Crisis of 1973-1974 (Boston: Bedford, 2007); A. Gfeller, Building a European Identity: France, the United States, and the Oil Shock 1973-1974 (New York: Berghahn, 2012); H. Türk, "Energy Cooperation Among Western Industrialized Countries," Historical Social Research 39, no.4 (2014): 209-213; A. Price- Smith, Oil, Illiberalism, and War: An Analysis of Energy and US Foreign Policy (Cambridge: MIT Press, 2015); M. Jacobs, Panic at the Pump: The Energy Crisis and the Transformation of American Politics in the 1970s (New York: Hill \& Wang, 2016).

${ }^{14}$ For examples, see P. Tertzakian and K. Hollihan, The End of Energy Obesity: Breaking Today's Energy Addiction for a Prosperous and Secure Tomorrow (Hoboken: John Wiley, 2009); K. Deffeys, When Oil Peaked (New York: Hill \& Wang, 2010); E. Levant, Ethical Oil: the Case for Canada's Oil Sands (Toronto: McClelland and Stewart, 2011); J. Beneš et al., "The Future of Oil: Geography versus Technology," Working Paper 12/109, International Monetary Fund (May 2012).

${ }^{15}$ For examples, see H. Mejcher, Imperial Quest for Oil: Iraq 1910-1928 (London: Ithaca, 1976); B. McBeth, British Oil Policy 1919-1939 (London: Cass, 1985); P. Ellis-Jones, Oil: a Practical Guide to the Economics of World Petroleum (Cambridge: Woodhead-Faulkner, 1988).
} 
published in 1976, is an important study of the secretive relationships between British governments and oil companies in the early twentieth century. Kent's narrative, however, ends in 1920, and she does not account for the cultural components that shaped British oil policies and relationships during the interwar period. ${ }^{16}$ G. G. Jones has also made significant contributions to the political and economic history of oil in Britain, publishing several books and articles between 1977-1981. Yet, his studies do not engage with any popular discourses of oil, focussing instead on corporate, diplomatic, and official histories. ${ }^{17}$

Historians of oil have presented narratives of the resource and its development that are both teleological and millenarian in nature, configuring oil as an inherently precious substance that, once discovered by intrepid explorers, would inevitably be unlocked, extracted, piped, priced, and consumed. ${ }^{18}$ Company histories, such as R. W. Ferrier and J. H. Bamburg's two-volume set on the History of the Anglo-Persian Oil Company, and T. A. B. Corley's History of the Burmah Oil Company, are valuable for their privileged access to archival materials and their presentation of substantial data sets, but they provide little in the way of critical analysis of oil and oil cultures during the period. ${ }^{19}$ In the volume on the twentieth century in their Oxford History of the British

\footnotetext{
${ }^{16}$ M. Kent, Oil and Empire: British Policy and Mesopotamian Oil, 1900-1920 (London: Macmillan, 1976).

${ }^{17}$ G. Jones, "The British Government and the Oil Companies 1912-1924: The Search for an Oil Policy," Historical Journal 20, no.3 (September 1977): 647-672; G. Jones, "The Oil-Fuel Market in Britain 19001914: A Lost Cause Revisited," Business History 20, no.2 (July 1978): 131-152; G. Jones, The State and the Emergence of the British Oil Industry (London: Macmillan, 1981).

${ }^{18}$ For examples, see A. Crosby, Children of the Sun: a History of Humanity's Unappeasable Appetite for Energy (New York: W.W. Norton, 2006); L. Maugeri, The Age of Oil: the Mythology, History, and Future of the World's Most Controversial Resource (Guilford, CT: Lyons, 2008); J. Laxer, Oil (Toronto: Groundwood, 2008); F. al-Chalabi, Oil Policies, Oil Myths: Analysis and Memoir of an OPEC Insider (London: I.B. Tauris, 2010); M. Morton, Empires and Anarchies: History of Oil in the Middle East (London: Reaktion, 2017).

${ }^{19}$ R. Ferrier, The History of The British Petroleum Company, Vol. 1, The Developing Years, 1901-1932 (Cambridge: Cambridge University Press, 1982); J. Bamberg, The History of the British Petroleum Company, Vol. 2, The Anglo-Iranian Years, 1928-1954 (Cambridge: Cambridge University Press, 1994);
} 
Empire, W. M. R. Louis et al. dedicate only a few sentences to oil, which they treat as an exclusively commercial and military substance. ${ }^{20}$ They provide no sense of the dramatic rise in imperial oil consumption during the period, or the different ways that the resource was imagined and represented - a classic example of historians silence on energy.

The narratives that emerge from these types of political, economic, and military approaches to oil rest upon an array of assumptions: that oil would inevitably be discovered; that it would inevitably be extracted; that it would inevitably be consumed; and that contemporary societies would inevitably require more of it. Furthermore, these narratives tell tales of adventure that overlook the complexities of oil and oil cultures. This veneration of oil as a desirable, even irresistible object, which possesses almost magical qualities, is evident in much of the historical literature on the subject. It treats the resource as a powerful and dynamic liquid that moves from place to place throughout its lifecycle, causing change - and being changed - along its journey from beneath the ground, to its point of consumption, and on to its final ascent into the atmosphere. Perhaps the most notable example of such a tidy and linear story of oil can be found in Daniel Yergin's celebrated study, The Prize: The Epic Quest for Oil, Money and Power, where the author sensationalizes petroleum as the object of a dramatic "Great Game" of

T. Corley, History of the Burmah Oil Company, 1886-1924 (London: Heinemann, 1983). The author of a 1995 history of British Petroleum (BP) introduced his text by stating that the story of the company was "a political drama, rich in intrigue, with BP's fate inextricably entwined in the endless struggle between nations for control of one of the world's most valuable resources." (B. Ritchie, Portrait in Oil: an Illustrated History of BP (London: James \& James, 1995): 7). For a selection of corporate material published by British oil companies during the mid-twentieth century, see L. Lockhart, The Record of the Anglo-Iranian Oil Company, Ltd. (London: Anglo-Iranian Oil Company, 1938); Anglo-Iranian Oil Company, The Anglo-Iranian Oil Company and Iran (London: the Company, 1951); Anglo-Iranian Oil Company, Fifty Years of Oil (London: the Company, 1952); L. Lockhart and R. Greaves, The Record of the British Petroleum Limited (1918-1946): Relations with the Persian (Iranian) Government (London: British Petroleum, 1968); British Petroleum, Britannic House: a Palace Upon a Cliff (London: the Company, 1991).

${ }^{20}$ W. M. R. Louis et al. (eds.), The Oxford History of the British Empire. Vol 4: the Twentieth Century (Oxford: Oxford University Press, 1999). 
global command and control. ${ }^{21}$ The conclusions drawn by Yergin are underwritten by many of the same themes and storylines that were in use during the late nineteenth and early twentieth centuries; namely, that "in the twentieth century, oil...toppled King Coal from his throne as the power source for the industrialised world," instigating a revolutionary energy transition that made "possible where we live, how we live, how we commute to work, how we travel - even where we conduct our courtships." ${ }^{22}$ The primary narrative in this literature is that the late-nineteenth and early-twentieth century emergence of oil in Britain was a certain and uncontested phenomenon that occurred evenly across time and space.

In recent years, a new phase of multidisciplinary research has sought to situate oil in its many cultural contexts by moving away from the metrics of barrels per day, prices at the pumps, the number of motor vehicles on the road, or the cost of oil wars, and turning instead toward analyses that situate oil as a contested and socially constructed phenomenon. Scholars from a wide range of disciplines have begun to devote attention to the cultural dimensions of energy and, in turn, have explored the influence that oil has exercised upon the images and practices of everyday life. Some have examined the energy transition away from fossil fuels, and its concomitant sociopolitical consequences, particularly oil and its relationship with war and global conflict. ${ }^{23}$ The "resource curse" thesis is another popular analytical framework in the existing energy history literature,

${ }^{21}$ D. Yergin, The Prize: the Epic Quest for Oil, Money and Power (New York: Simon and Shuster, 1991): 21.

${ }^{22}$ Yergin, 1991): xvi.

${ }^{23}$ For examples, see W. Engdahl, A Century of War: Anglo-American Oil Politics and the New World Order (London: Pluto, 2004); D. Hiro, Blood of the Earth: the Battle for the World's Vanishing Oil Resources (New York: Nation, 2007); J. Colgan, Petro-Aggression: When Oil Causes War (Cambridge: Cambridge University Press, 2013); R. Partanen et al., The World After Cheap Oil (New York: Routledge, 2015); D. van de Ven and R. Fouquet, "Historical Energy Price Shocks and their Changing Effects on the Economy," Energy Economics 62 (2017): 204-216. 
which holds that oil possesses a corrosive power over the societies that live on or near petroleum deposits. ${ }^{24}$ There is also a growing body of research on the phenomenon of energy transitions writ large, both historical and contemporary, and the social, cultural, political, and economic processes that influence the trajectory of such shifts. ${ }^{25}$ Cultural histories of oil and energy are also beginning to emerge, particularly in the United States. Nancy Quam-Wickham's article on oil discourses in 1920s Los Angeles; Paul Sabin's book, Crude Politics: The California Oil Market, 1900-1940; T. L. Friedel's study of cultural representation in oil advertising; Sarah Strauss's edited collection examining Cultures of Energy; and Bob Johnson's probe of fossil fuels and American culture are important contributions. ${ }^{26} \mathrm{~A}$ small body of literature also exists on the cultural history of oil in Iran, and the colonial relationships that formed after the discovery of hydrocarbons in the early twentieth century. This scholarship has been particularly valuable to the present inquiry because Iran was the oil producing country with which Britain had a very close relationship during the period under investigation, as chapters three and four will demonstrate. Scholars working in this field include Mark

\footnotetext{
${ }^{24}$ On the resource curse thesis, see R. Auty, Sustaining Development in Mineral Economies: The Resource Curse Thesis (London: Routledge, 1993); P. Le Billon, "Resources," in K. Dodds et al. (eds.), The Ashgate Research Companion to Critical Geopolitics (Farnham: Ashgate, 2013): 291.

${ }^{25}$ For examples, see B. Podobnik, "Toward a Sustainable of Energy Regime: a Long-Wave Interpretation of Global Energy Shifts," Technological Forecasting and Social Change 62 (1999): 155-172; B. Podobnik, Global Energy Shifts: Fostering Sustainability in a Turbulent Age (Philadelphia: Temple University Press, 2006); I. Bashmakov, “Three Laws of Energy Transitions," Energy Policy 35, no.7 (2007): 3583-3594; R. Fouquet, "The Slow Search for Solutions: Lessons from Historical Energy Transitions by Sector and Service," BC3 Working Paper Series 2010-05 (Bilbao, Spain: Basque Centre for Climate Change (BC3), 2008; V. Smil, Energy Transitions: History, Requirements, Prospects (Westport: Praeger, 2010); A. Grubler, "Energy Transitions Research: Insights and Cautionary Tales," Energy Policy 50 (2012): 8-16. ${ }^{26}$ For examples, see N. Quam-Wickham, "'Cities Sacrificed on the Altar of Oil': Popular Opposition to Oil Development in 1920s Los Angeles," Environmental History 3, no.2 (April 1998): 189-200; D. Olien, Oil in Texas: the Gusher Age 1895-1945 (Austin: University of Texas Press, 2002); L. McQuaig, It's the Crude, Dude: War, Big Oil, and the Fight for the Planet (Toronto: Doubleday, 2004); P. Sabin, Crude Politics: the California Oil Market, 1900-1940 (Berkeley: University of California Press, 2005); B. Jonson, Carbon Nation: Fossil Fuels in the Making of American Culture (Lawrence: University Press of Kansas, 2014).
} 
Crinson, an expert on energy and architecture; Mona Damluji, an expert on historical oil films; and Nelida Fuccaro and Nimrod Zagagi, who have investigated the history of oil company towns in the Middle East. ${ }^{27}$ These authors rely heavily on official and corporate sources in their studies, particularly government reports and corporate records of oil companies. Very little attention is paid to sources beyond these collections and no account is taken of commercial advertising, pamphlets and booklets, newspaper and magazine reportage, or events such as private tours and official celebrations.

As already noted, one of the most active scholars working in the Energy Humanities is Imre Szeman. ${ }^{28}$ He has written widely on energy, and in particular on oil and the ways in which the resource has shaped contemporary daily life. ${ }^{29}$ Szeman has used his findings to ponder how societies might adapt to a future world without oil. ${ }^{30}$

\footnotetext{
${ }^{27}$ For examples, see M. Crinson, Empire Building: Victorian Architecture and Orientalism (London: Routledge, 1996); M. Crinson, "Abadan: Planning and Architecture Under the Anglo-Iranian Oil Company," Planning Perspectives 12, no.3 (1997): 341-359; M. Crinson, Modern Architecture and the End of Empire (Aldershot: Ashgate, 2003); M. Crinson, "Imperial Modernism," in Alex Bremner (ed.), Architecture and Urbanism in the British Empire (Oxford: Oxford University Press, 2016); M. Damluji, "Documenting the Modern Oil City: Cinematic Urbanism in Anglo-Iranian's Persian Story," Ars Orientalis 42 (October 2012); M. Damluji, "The Oil City in Focus: the Cinematic Spaces of Abadan in the AngloIranian Oil Company's Persian Story," Comparative Studies of South Asia, Africa and the Middle East 33 (2013): 75-88; N. Fuccaro, "Histories of Oil and Urban Modernity in the Middle East," Comparative Studies of South Asia, Africa and the Middle East 33 (2013): 1-6; N. Zagagi, "Urban Area and Hinterland: the Case of Abadan (1910-1946)," Journal of the Middle East and Africa 1 (2016): 61-83. ${ }^{28}$ For a sampling of other scholars currently working in the Energy Humanities, see J. Wenzel, "PetroMagic-Realism: Toward a Political Ecology of Nigerian Literature," Postcolonial Studies 9, no.4 (2006): 449-464; P. Hitchcock, "Oil in an American Imaginary," New Formations 69 (2010): np; D. Boyer, "Energopolitics and the Anthropology of Energy," Anthropology Newsletter (May 2011): np; M. Huber, "Energy, Environment and the Geopolitical Imagination," Political Geography 31, no.6 (2012); G. Takach, "Selling Nature in a Resource-Based Economy: Romantic/Extractive Gazes and Alberta's Bituminous Sands," Environmental Communication 7, no. 2 (2013): 211-230; J. Urry, Societies Beyond Oil: Oil Dregs and Social Futures (London: Zedbooks, 2013); D. Boyer, "Energopower: An Introduction," Anthropological Quarterly 8, no. 2 (2014): 309-34; S. LeMenager, Living Oil: Petroleum Culture in the American Century (New York: Oxford University Press, 2014); J. Wenzel, "How to Read for Oil," Resilience 1, no. 2 (2014); J. Diamanti and B. Bellamy, "Energy Humanities," Reviews in Cultural Theory 6, no. 3 (2016): 9; H. Graves and D. Beard (eds.), The Rhetoric of Oil in the Twenty-First Century: Government, Corporate and Activist Discourses (London: Routledge/Taylor-Francis: Forthcoming, 2018). ${ }^{29}$ I. Szeman and D. Boyer (eds.), Energy Humanities: an Anthology (Baltimore: Johns Hopkins, 2017).

${ }^{30}$ For examples, see I. Szeman, "Crude Aesthetics: the Politics of Oil Documentaries," Journal of American Studies 46 (2012): 423-439; I. Szeman, "How to Know About Oil: Energy Epistemologies and Political Futures," Journal of Canadian Studies 47 (2013): 145-68; I. Szeman and M. Whiteman, "Oil
} 
Most recently, he co-published a SSHRC Knowledge Synthesis Grant report on the state of the field of the Energy Humanities. He and his colleagues argue that energy has "played a specific, hitherto under-explored, and consequently not well-understood role in shaping the values, habits and beliefs that have generated the current human-environment relationship." They confirmed Sandwell's observations about historians' silence on energy, and concluded that, despite being "foundational to the form and character of human societies," energy is "only now beginning to be seriously investigated." 31 This dissertation is inspired in part by the insights and challenges laid down in this 2016 report.

Two recent scholarly collections have also played an instrumental role in the shaping of this dissertation. The first is a special issue of the Journal of American Studies on oil cultures, published in 2012 and co-edited by Ross Barrett and Daniel Worden. In their introduction, the editors stated that the issue represented "the first comprehensive account of 'oil culture,' the broad field of cultural representations and symbolic forms that have taken shape around the fugacious material of oil." ${ }^{32}$ In 2014, the articles were re-published as an edited collection, entitled Oil Cultures. This work has now become a foundational text in the Energy Humanities, marking the emergence of what the editors describe as a new body of literature "attentive to oil's cultural presence in the various social, economic, and political realms that constitute the global petroleum system." ${ }^{33}$ As

\footnotetext{
Imag(e)ries: Critical Realism and the Oil Sands," Imaginations 3, no. 2 (2012); I. Szeman (ed.), After Oil (Edmonton: Petrocultures Research Group, 2016).

${ }^{31}$ I. Szeman, On the Energy Humanities: Contributions from the Humanities Social Sciences, and Arts to Understanding Energy Transition and Energy Impasse. SSHRC Knowledge Synthesis Grant: Energy and Natural Resources. Final Report, May 2016, 7.

${ }^{32}$ R. Barrett and D. Worden, "Oil Culture," Journal of American Studies 46, no. 2 (2012): 269.

${ }^{33}$ R. Barrett and D. Worden (eds.), Oil Culture (Minneapolis: University of Minnesota Press, 2014): xxiii.
} 
Barrett and Worden contended, scholars studying oil from within the humanities must work to disentangle the "many dimensions of oil's cultural existence" by assessing the resource "as both an industry and a culture, a business and a set of aesthetic practices, a natural resource and a trope. ${ }^{\prime 34}$ Specifically, these scholars argue that oil can only be known through "creative accounts" and "the unceasing generation of imaginative interpretations of its value." 35 These efforts to understand and inscribe oil with new meanings have the effect, according to Barrett and Worden, of producing in the mind of the consumer an "oil spectacle." 36 Taken as a whole, research in the Energy Humanities is raising searching questions about the ontology of oil, and the different ways that people have come to understand the resource as both a physical and cultural object.

This dissertation makes a direct contribution to Barrett and Worden's larger project of the Energy Humanities by undertaking a critical investigation into the cultural constructs that shaped Britons' understandings of oil and its impact on their lives. It uses Barrett and Worden's concepts of "creative accounts" and "imaginative spectacles" as tools for analysing British petroculture during the late nineteenth and early twentieth century. In so doing, the dissertation argues that oil must be configured as an inherently unstable and unfinished artifact, and demonstrates that the resource was imagined as something that was brought to life through discourse rather than drilling, through conversation rather than chemistry. In undertaking this approach, the dissertation seeks to contribute a richer account of the multi-layered history of British experiences with and

\footnotetext{
${ }^{34}$ R. Barrett and D. Worden, 2014, xxi. In his forward to the collection, Allan Stoekl echoed similar sentiments, writing: "It's when we think about what 'oil history' could mean that we take a natural entity and recognize its cultural centrality" (xii).

${ }^{35}$ R. Barrett and D. Worden, 2014, xxiii-xxv.

${ }^{36}$ R. Barrett and D. Worden, 2014, xxiii-xxv.
} 
attitudes towards oil, leading to an innovative analysis of the cultural processes that helped Britons navigate the transition to the "Age of Oil."

\section{Historical Considerations}

In 1865 , Britain was a coal country, and had been so for over a century. ${ }^{37}$ During the 1890 s and early 1900 s, there were more than 3,200 coal companies operating in Britain, producing upwards of 200 million tonnes of coal per year. ${ }^{38}$ In addition to supplying British consumers with a cheap and local source of energy, coal was one of Britain's most valuable export commodities. In 1880, the country exported 23 million tonnes of the hard, bulky resource; by 1913, 95 million tonnes of coal were exported to ports around the world, most of it being transported in British ships. ${ }^{39}$

Oil products and their associated technologies transformed the everyday lives of Britons. The first uses of oil in Britain were for illumination, most notably kerosene lamps and paraffin candles, which had become ubiquitous by the beginning of the twentieth century. ${ }^{40}$ As a result of advancements in the chemical industry and in the field of chemical engineering, scores of new oil products and technologies came on to the British market, including agricultural fertilizers and pesticides; industrial greases and

\footnotetext{
${ }^{37}$ P. Warde, Energy Consumption in England and Wales, 1560-2000 (Rome: Consiglio Nazionale delle Ricerche, 2007): 69.

${ }^{38}$ Department of Energy and Climate Change (UK), Historical Coal Data: Coal Production, Availability and Consumption 1853-2014 (London: HMSO, 2015).

${ }^{39}$ M. Fletcher, "From Coal to Oil in British Shipping," Journal of Transport History 3, no. 1 (February 1975): 3.

${ }^{40}$ According to the oil journalist James Dodds Henry's calculations, the Anglo-American Oil Company sold in 1907 more than 100 million gallons of illuminating oil in Britain, which represented "enough to fill eight hundred million ordinary lamps...more than sufficient to go four times round the world!" J. Dodds Henry, 1907, 32. On the development of oil for illuminating purposes see W. Antrobus, Oil (London: John Heywood, 1913): 36; "The Petroleum Industry," The Times 4 March 1914, 8; Imperial Institute, Petroleum (London: John Murray, 1921): 16.
} 
lubricants; household paints and solvents; waterproofing for clothing; laundry detergent; cosmetic products; and preservatives for meat and fish. ${ }^{41}$ In the realm of industry and manufacturing, oil made possible more powerful and efficient machinery, and oil-fuelled furnaces created even and consistent heat. Oil-fuelled boilers also began to emerge during the first decade of the twentieth century. In 1903, the Great Eastern Railway, one of the busiest in Britain, converted 80 of its 1,200 engines from coal to oil. ${ }^{42}$ Similar technologies were applied to agricultural machinery, including ploughing machines, harvesters, and tractors. ${ }^{43}$

One of the most significant oil-related technological developments occurred at sea, where liquid fuel was gradually adopted as an alternative to coal for raising steam. Oil offered several advantages over coal in maritime applications: it took up less space; it could fit in any compartment on a ship, often freeing up cargo space for bulkier commodities; it raised power more quickly; it held maximum burning temperature more steadily; and it was cleaner and safer to handle than coal. Of particular value at sea was

${ }^{41}$ Redwood, 1886, 85. On the historical development of the British chemical industry, see D. Hardie, $A$ History of the Modern British Chemical Industry (Oxford: Pergamon, 1966); W. Campbell, The Chemical Industry (London: Longman, 1971); Royal Society of Chemistry, Chemistry, Society and Environment: A New History of the British Chemical Industry (Cambridge: The Society, 2000). On new consumer products and technologies made available by oil, see K. Swann, "What Do You Know About Your Gas or Oil Stove?" Woman's Health 32 (1905): 52-54; G. Melville, "Liquid Fuel for Naval and Marine Purposes," Scientific American, S61 (February 1906): 25183; J. Gairns, "Petrol Tractors," Cassier's 32 (1907): 84-92. ${ }^{42}$ G. Measom, Official Illustrated Guide to the Great Eastern Railway (London: C. Griffin, 1865); D. Haws, Merchant Fleets: Britain's Railway Steamers (Hereford: TCL, 1993). On the history of the Great Western Railway and its shift to oil fuel, see G. Sekon, A History of Great Western Railway (London: Digby, Long \& Co., 1895); W. Acworth, The Railways and the Traders (London: John Murray, 1906); B. Acworth, "Coal in Relation to Transport and Power," Great Western Railway (London) Lecture and Debating Society, no. 276 (16 November 1933): 1-13; O. Nock, Great Western Railway in the Twentieth Century (London: George Allan, 1964).

${ }^{43}$ On the history of industrial farming and agriculture in Britain, see G. Fussell, Farming Technique from Prehistoric to Modern Times (New York: Pergamon, 1965); R. Hurt, The History of Agricultural Science and Technology: An International Annotated Bibliography (New York: Garland, 1994); A. Wilt, Food for War: Agriculture and Rearmament in Britain Before the Second World War (Oxford: Oxford University Press, 2001). 
oil's fluidity, which made it easier to load and move about the ship. For merchant and naval craft alike, oil meant faster refueling times and fewer stokers. ${ }^{44}$

In 1901, the British Royal Navy, which for half a century had been the largest consumer of British steam coal in the world, began to adopt oil fuel. In that year, the Admiralty ordered the construction of five oil-powered submarines and, ten years later, Winston Churchill, then serving as First Lord of the Admiralty, began to convert Britain's primary fleet of battleships from coal to oil fuel - a rapid and controversial energy transition motivated by what the First Sea Lord, Sir John Arbuthnot Fisher, described as "Internal-combustion engines rabies!" 45 The speed of the Navy's transition from coal to oil, and the consequences of that decision on coal mining regions in South Wales were striking. The Admiralty ordered 1,200 tons of oil products in 1902, and by 1912 it was buying nearly 300,000 tons per year. ${ }^{46}$ That same year, in 1912, the Royal Navy purchased 1.65 million tons of coal from companies in South Wales; by 1929, the amount had dropped to just 150,000 tons ${ }^{47}$ Churchill later wrote that the decision to transition to oil was a "fateful plunge" into an unknown and uncertain future, but by the

\footnotetext{
${ }^{44}$ According to one estimate made in 1907, if the Lusitania had been built to burn oil, it could have reduced its required complement of engine room workers from 312 to 27. Jones, 1978, 138.

45 “Agreement between The Lords Commissioners of His Majesty's Treasury, The Commissioners for Executing the Office of Lord High Admiral of the United Kingdom of Great Britain and Ireland, and the Anglo-Persian Oil Co. Ltd., for the Purchase of Shares in the Anglo-Persian Oil Co. Ltd. by His Majesty's Government." 20 May 1914. British Petroleum Archives, ARC 106214-106215; J. Fisher, Memories (London: Hodder and Stoughton, 1919); A. Marder, Fear God and Dread Nought: The Correspondence of Admiral of the Fleet Lord Fisher of Kilverstone (London: Cape, 1953-1959); R. Massie, Dreadnought: Britain, Germany, and the Coming of the Great War (New York: Random House, 1991). In 1912, Churchill ordered the construction of several new battleships powered exclusively by oil. The first of these "Fast Division" oil-burners, the Queen Elizabeth, was laid down on 9 April 1912. The British magazine, Punch, portrayed the conversion of the navy to oil in a cartoon in which Churchill, dressed as a young schoolboy, pours oil from a small can into a miniature battleship. "Essence of Parliament," Punch, 6 August 1913, 133. ${ }^{46}$ Jones, 1978, 145.

${ }^{47}$ Back to Coal Movement, "Minutes of Proceedings of an Address given by Captain Bernard Acworth, D.S.O., R.N. on 'The Navy's Fuel,"” 1931-1932. National Library of Wales, Monmouthshire and South Wales Coal Owners Association Records, Box 1, A4/3/5; Back to Coal Movement, "Memorandum re Appeal to the Rt. Hon. Stanley Baldwin," 1932. Box 1, A4/4/26.
} 
end of the First World War nearly all major navies were, or already had begun, transitioning to oil fuel. ${ }^{48}$

The overwhelming majority of the oil products consumed in Britain were imported from foreign countries as far away as Persia, Russia, and the United States. Indeed, despite claiming political authority over nearly a quarter of the earth's landmass, the British Empire never produced more than two per cent of the world's oil during the period covered by this study. In contrast, between 1865 and 1925, the United States produced between 50 to 70 per cent of the world's oil, and in 1904 that country supplied 98 per cent of British oil imports. ${ }^{49}$ In spite of their high cost, oil products were popular in Britain. In total, imports of the resource rose by nearly five hundred per cent over the period 1899-1914, ${ }^{50}$ while per capita consumption of all petroleum products increased from around 7 gallons in 1901 to more than 15 gallons in $1914 .^{51}$

Oil, therefore, provided a powerful (albeit expensive) substitute for several other energy resources during the period of this study, including coal, wind, water, and provender. Oil products also permitted the development of entirely new technologies, especially in the realm of transportation. The two most prominent of these were the

${ }^{48}$ B. Redwood, "The Future of Oil Fuel," Journal of the Royal Society of Arts 62 (26 December 1913): 103-116. During the war, the German, Italian, Australian, Austro-Hungarian, Russian, American, Japanese, and Dutch navies converted to oil fuel. Lord Ailwyn, "Fuel for the Navy," Naval Review 25, no. 3 (August 1937): 451-467.

${ }^{49}$ The peak of 98 per cent was reached in 1904. Department for Business, Energy \& Industrial Strategy (UK), Crude Oil and Petroleum Products: Imports by Product 1920-2015 (London: HMSO, 2016); Crude Oil and Petroleum: Production, Imports and Exports 1890 to 2015 (London: HMSO, 2016). On the search for oil in the British Isles, see E. Cunningham-Craig, Oil Finding: An Introduction to the Geological Study of Petroleum (London: E. Arnold, 1920); "Fuel for the Navy," Naval Review 25, no.3 (August 1937): 452; J. Roberts, "The Search for Oil," Royal Society of Arts Journal 86, no.4455 (April 1938): 488-525.

${ }^{50}$ Department for Business, Energy \& Industrial Strategy (UK), Crude Oil and Petroleum: Production, Imports and Exports 1890 to 2015 (London: HMSO, 2016). Imports of motor spirits nearly doubled from 1905 to 1907. "The Supply of Petroleum," The Times, 29 July 1908, 4.

${ }^{51}$ The Times, 29 July 1908, 4; G. Jones, The State and the Emergence of the British Oil Industry (London: Macmillan, 1981): 43. 
airplane and the automobile. In 1903, the Wright brothers completed their famous flight above Kitty Hawk, North Carolina, and five years later, Samuel Franklin Cody became the first person in Britain to fly an airplane.$^{52}$ Both of these aircraft used highly refined petroleum spirits, and their success initiated a surge of interest in aeronautics in Britain, particularly among the country's affluent classes.$^{53}$ The use of private aircraft quickly expanded in the years that followed Cody's flight and, in 1912, a 250-acre aerodrome was constructed at Harrow to accommodate the rising number of private flying clubs in London. ${ }^{54}$ The development of military aviation occurred simultaneously during this period. In the spring of 1912, the Army and Navy held the first open competition to procure new military aircraft, and the Royal Flying Corps was established. ${ }^{55}$

The most dramatic changes brought about by the advent of refined oil products in Britain came as a result of the rapid expansion in the use of automobiles. The first oilfuelled motorcars were developed in the late 1890s, and their use in Britain accelerated in the decades that followed. ${ }^{56}$ By the turn of the twentieth century, petroleum-fuelled automobiles, buses, delivery vans, and motorcycles were commonplace in many parts of Britain. The number of licenced drivers grew from a few hundred to more than 1.5 million in $1925 .{ }^{57}$ These new motorists required a whole suite of new products and

\footnotetext{
52 "British Aeroplane and Airship," Flight, 22 May 1909; A. Gollin, The Impact of Air Power on the British People and Their Government, 1909-1914 (Basingstoke: Macmillan, 1989).

${ }^{53}$ In January 1909, the Aero Club of the United Kingdom launched a new journal, Flight, which covered the "Interests, Practice, and Progress of Aerial Locomotion and Transport." Flight, 2 January 1909, 1.

54 "The Future of Aviation in England," The Times, 3 February 1912, 6.

55 “Aeroplanes in War," The Times, 13 April 1912, 7; United Kingdom Parliamentary Papers, "Army. Military Aeroplane Competition," 1912, vol. 51, Cd. 6286; United Kingdom Parliamentary Papers, "Army. Memorandum on Naval and Military Aviation," 1912, vol. 51, Cd. 6067.

${ }^{56}$ United Kingdom Parliamentary Papers, "Royal Commission on Motor Cars, Vol. 1, Report," 1906, vol. 48, Cd. 3080, 11; C. Brunner, The Problem of Oil (London: Ernest Benn, 1930): 223.

${ }^{57}$ The Autocar, 2 April 1899, 7; "Petrol Supplies," The Times, 17 March 1926, xxix; A. Prest, Consumers' Expenditure in the United Kingdom, 1900-1919 (Cambridge: Cambridge University Press, 1954): 142. Forty per cent of these licences were for private automobiles, and thirty-four per cent for motorcycles. The remainder applied to buses and commercial vehicles.
} 
technologies, including vehicles, repair shops, tires, fuel, and fuelling stations. The speed at which automobiles were adopted in Britain was remarkable. In 1900, 700 new motor vehicles of various types were purchased in Britain, but by 1904 there were 51,000 motor vehicles in the country. In 1912 alone, Britons purchased 20,000 new motor vehicles. ${ }^{58}$

The multitude of new vehicles consumed increasing quantities of motor spirits, both during daily commuting and weekend jaunts to the countryside. In 1910, 1.6 million barrels of oil were consumed in Britain; by 1925, the figure had grown to 11.5 million barrels. ${ }^{59}$ Imports of motor spirit rose from 474,610 barrels in 1905 to 809,250 barrels in 1907, feeding the ever-increasing demand for petrol, which in 1913 was estimated at 100 million gallons per year. ${ }^{60}$ This surge in motor spirit consumption required a vast network of oil infrastructure to be built throughout the country, including oil refineries, pipelines, port facilities, storage tank farms, distribution warehouses, delivery vehicles, and service station pumps. As the consumption of oil in Britain increased, advances in the dispensing technology kept pace. ${ }^{61}$ In 1919 , the first curb-side motor spirit pumps were installed in Britain by the Anglo-American Oil Company, and two years later the company constructed one of the first petrol filling stations in London, on Harrow Road ${ }^{62}$ Several

\footnotetext{
58 "Royal Commission on Motor Cars," 1906, Cd. 3080, 11; Antrobus, 1913, 91-92; Brunner, 1930, 223; Prest, 1954, 142. In 1905, there were 29 firms producing automobiles in the city of Coventry. N. McCord and B. Purdue, British History 1815-1914 (Oxford: Oxford University Press, 2007): 493.

59 "Petrol Supplies," The Times, 17 March 1926, xxix; Lidgett, 1919, 160. One standard barrel of oil consists of thirty-five imperial gallons.

60 "The Supply of Motor Spirit," The Times, 23 July 1913, 26.

${ }^{61}$ During the nineteenth century, oil was transported from distributors to consumers in wooden barrels and crates. On the evolution of oil transport technology, see G. Montague, "The Transport Phase of the Oil Industry," Journal of Political Economy 15, no.8 (October 1907): 449-469; "History of the 42-Gallon Oil Barrel," American Oil \& Gas Historical Society, no date. Retrieved from: www.aoghs.org/transportation/history-of-the-42-gallon-oil-barrel.

${ }^{62}$ F. Gardner, "Motor Spirits, Solvents, Diesel Fuels, Etc.," in A. Dunstan (ed.), The Science of Petroleum, Vol. IV (London: Oxford University Press, 1938): 2391-2394; D. Dixon, "Petrol Distribution in the U.K., 1900-1950," Business History 6, no. 1 (1963): 7. On the historical development of the petrol filling station in Britain, see K. Morrison and J. Minnis, Carscapes: The Motor Car, Architecture and Landscape in England (New Haven: Yale University Press, 2012); "When Did England's First Filling Station Open?"
} 
other oil companies began to develop similar distribution infrastructure and, by 1926, there were more than 20,000 petrol pumps in operation across the country. ${ }^{63}$

The British populace in urban areas increasingly saw, smelled, and heard the motor vehicles that filled the streets of cities and towns, while rural residents began to encounter oil-fuelled tractors and farming equipment, and the steady stream of weekend motorists. For the most fortunate in British society, oil fuel opened up opportunities for owning and using private aircraft, racing boats, and motor yachts, a variety of different automobiles and motorcycles, and oil-fuelled heating and cooking appliances. ${ }^{64}$ By the mid-1920s, luxurious British lawns could be kept trim with oil-fuelled riding mowers. ${ }^{65}$ This portrait of a country on the cusp of a revolutionary energy transition to oil is represented in a graph presented below, which tracks the overall use of energy in Britain by source. [Figure 1]. The graph was created by energy historian Roger Fouquet, and it

Historic England, undated. Retrieved from: www.historicengland.org.uk/listing/what-isdesignation/heritage-highlights/englands-first-filling-station.

${ }^{63}$ Garage and Motor Agent, 13 November 1926, 58; Dixon, 1963, 7. In 1928, the Royal Society of Arts held a contest, with cash prizes, challenging British architects to design an attractive petrol station. The following year, the Royal Institute of British Architects, in concert with the Royal Automobile Club, organized a similar competition that received 110 designs. See Petroleum Times, February 1928, 7; Daily Express, 23 August 1929; "Beauty and the Pump," The Times, 20 August 1930, 11; R. Brown, "Cultivating a 'Green' Image: Oil Companies and Outdoor Publicity in Britain and Europe, 1920-1936,' Journal of European Economic History 22, no.2 (Fall 1993): 355.

${ }^{64}$ For examples, see F. Grover, A Practical Treatise on Modern Gas and Oil Engines (Manchester: Technical Publishing, 1897); A. Goldingham, The Design and Construction of Oil Engines (London: Spon, 1900); W. Tower and J. Robert, Petroleum: The Motive Power of the Future (London: Hodder \& Stoughton, 1912); E. Bowden-Smith, Oil Firing for Kitchen Ranges and Steam Boilers (London: Archibald Constable, 1920); J. Gander, Oil Fuel Burning At Sea and On Land (Glasgow: James Munro, 1923). For examples of contemporary American oil literature, see G. Burrell, Gasoline and How to Use It (Boston: Oil Statistical Society, 1916); S. Andros, Fuel Oil in Industry (Chicago: Shaw, 1920); T. Boyd, Gasoline: What Everyone Should Know About It (New York: Frederick A. Stokes, 1925); P. Fansler, House Heating with Oil Fuel (New York: Heating and Ventilating Magazine, 1925).

${ }^{65}$ A. Dunstan (ed.), The Petroleum Industry (London: Institute of Petroleum Technologists, 1922): 73. 
provides a two-dimensional illustration of the major energy shift that defined the period of this study - the downfall of coal and rise of oil as Britain's dominant energy regime. ${ }^{66}$

Figure 1: Share of primary energy consumption in the United Kingdom (1500-2000)

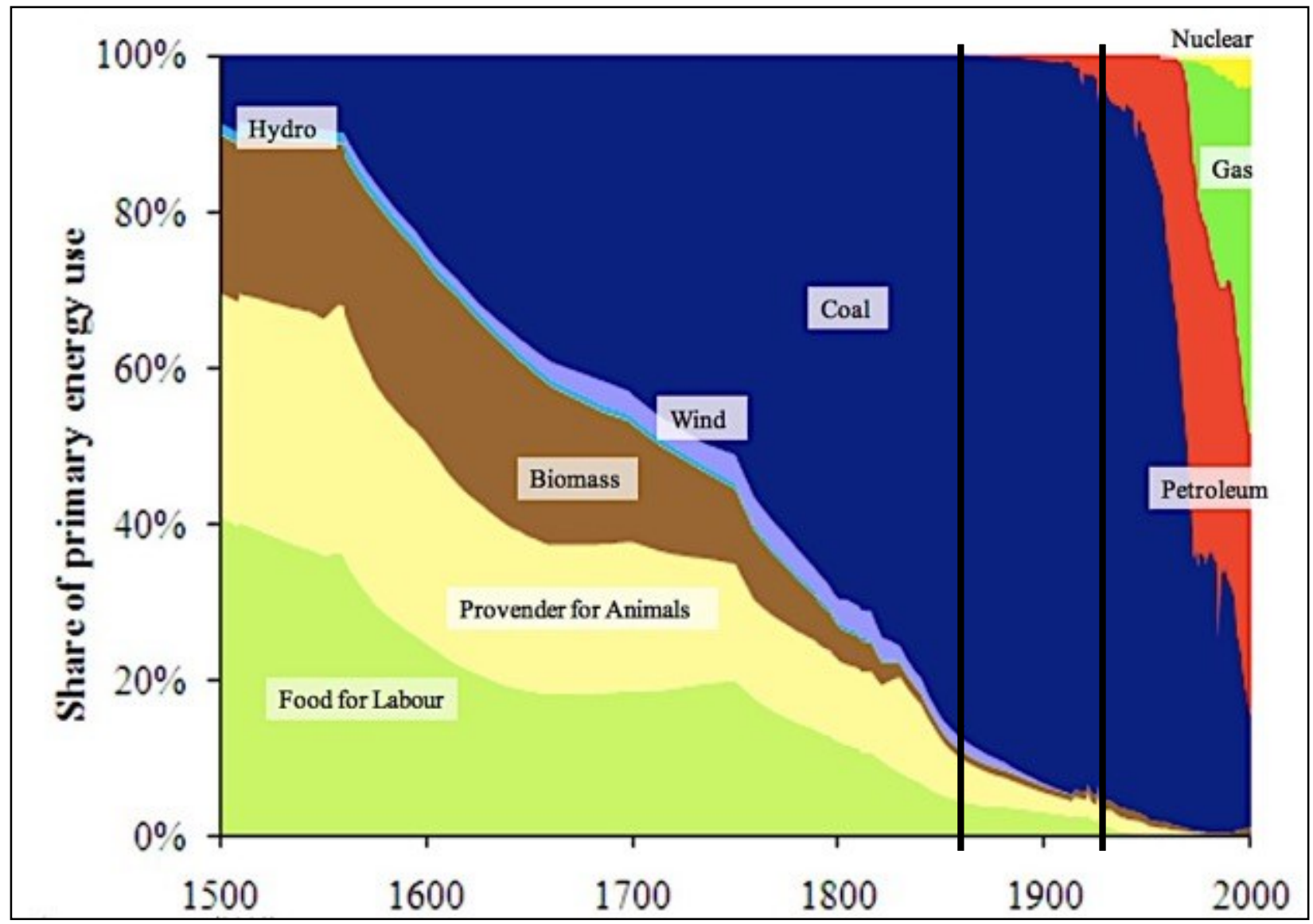

Roger Fouquet, "The Slow Search for Solutions: Lessons from Historical Energy Transitions by Sector and Service.” Bilbao: Basque Centre for Climate Change (BC3), 2008.

\footnotetext{
${ }^{66}$ The graph was compiled by energy historian Roger Fouquet, and appears in R. Fouquet, "The Slow Search for Solutions: Lessons from Historical Energy Transitions by Sector and Service,” BC3 Working Paper Series 2010-05 (Bilbao, Spain: Basque Centre for Climate Change (BC3), 2008).
} 


\section{Oil Discourse and the Making of British Petroculture}

Despite the growing presence of oil in Britain during the late nineteenth and early twentieth centuries, the resource was paradoxically a spectral substance, which was rarely seen or touched directly by the British consumer. As energy scholar Alan Stoekl has argued, oil has always been a substance shrouded in a "history of invisibility," and this is certainly true for Britain. ${ }^{67}$ Oil extraction and consumption, for instance, was radically different from coal ${ }^{68}$ While Britons were familiar with the figure of the coal miner and the dangers of the mines and the slag heaps, or the coal merchant's deliveries of heating and cooking fuel to the coal shed, there was little available to form an understanding of oil and the systems that brought it from the well head to the consumer. For Britons, oil came from faraway lands. It arrived in their country by way of pipelines, ships, and sealed tankers, only to be poured into machinery and combusted in the recesses of engines. The rare moments when consumers did see oil, such as when it was burned for the purpose of illumination, it disappeared rapidly into the air and left no visible residue or ash. The dirt, smoke, and the infamous smog of London and Britain's large cities, on the other hand, made the consequences of burning coal visible. ${ }^{69}$ From 1865 to 1935 , the time span of this dissertation, the average British consumer used oil in increasing

\footnotetext{
${ }^{67}$ A. Stoekl, "Foreword," in R. Barrett and D. Worden (eds.), Oil Culture (Minneapolis: University of Minnesota Press, 2014): xiii.

${ }^{68}$ For a discussion of the structural differences between coal and oil extraction, and the labour dynamics involved in the production of each resource, see T. Mitchell, Carbon Democracy (London: Verso, 2011). ${ }^{69}$ The Oxford English Dictionary dates the earliest use of the word smog to 1905, at the Public Health Congress, held in London on 26 July. Dr. H. A. des Vœux, the Honorary Treasurer of the Coal Smoke Abatement Society, delivered a paper on "Fog and Smoke," in which he described "smoky fog, or what was known as "smog."” Daily Graphic, 26 July 1905, 10; "smog, n." OED Online. January 2018. Oxford University Press. www.oed.com/view/Entry/182692?rskey=4eji3D\&result=1\&isAdvanced=false (accessed 21 February 2018).
} 
quantities while never really seeing the resource itself. Yet, while oil was out of sight during this period, it was not out of mind.

The very nature of oil's invisibility demanded that Britons invent novel ways of thinking, talking, and writing about the resource - actions which produced an entirely new archive of images, stories, and ideas about energy and its cultural impact. Even the most basic elements of oil needed to be explained and conceptualized, from the essential questions of what oil was, to more technical enquiries into the science and engineering of oil refining, and the ways in which refined products could be used. Amorphous and difficult to explain, the resource could exist as a liquid, as a gas, and as a solid. Each state had several different names - crude oil, rock oil, petroleum, bitumen, naphtha, propane, benzene, kerosene, gas, spirit, paraffin, pitch, and others. It was the task of British scientists, oil companies, journalists, and artists, some of whom are discussed in this dissertation, to give life to oil and the opportunities it afforded the individual consumer.

A series of core themes connected the diverse means by which oil was imagined in Britain. The novelty of oil, mixed with the difficulty in getting it out of the ground, seemed a romance of modern science and technology. ${ }^{70}$ Often, the discovery of oil took on emotional connotations, as in a person's excitement over a new love interest, while at other times, the struggle between the driller and his prize, crude oil, was portrayed as a dramatic encounter with the natural environment. According to the British oil expert J. D.

\footnotetext{
${ }^{70}$ On the theme of romance in British oil literature, see B. Redwood, "The Romance of Petroleum," in A. Dunstan (ed.), The Petroleum Industry (London: Institute of Petroleum Technologists, 1922): 7-35; "Drama in Industry," Naft 6, no. 3 (May 1930): 3-4. The theme of romance was popular in American oil literature during the period, as well. See A. Crum, The Romance of American Petroleum and Gas (New York: Marcy, 1911); A. Davis, "Romance of California Oil," Overland 61 (1913): 124-134; O. Norman, The Romance of the Gas Industry (Chicago: A.C. McClurg, 1922); I. Marcossen, The Black Golconda: The Romance of Petroleum (New York: Harper, 1924); W. Woehlke, "California's Black Gold: The Romance of the Oil Gushers," Sunset 25 (1925): 173-187; G. Anderson, Romance of Royalty (Fort Worth: TannerWilliams, 1928); L. Graham, The Romance of Texas Oil (Forth Worth: Tariff, 1935).
} 
Henry, writing in his 1905 book, Baku: An Eventful History, the Russian energy industry was "romantically rich... Oil has made it so." "71 A frequent contributor to The Times, Henry's work often included the themes of romance in and dramatic encounter with exotic lands. ${ }^{72}$ Sir Herbert Russell, writing in 1922, found the advent of oil to be "a great romance indeed, for out of it has been born the aircraft, the submarine, the road vehicles of pleasure and commerce.",73

Oil as new and modern was at the very core of British thinking. As Barrett and Worden have demonstrated, "oil encourages fetishistic representations of its value as a magical property detached from labour," and this phenomenon was present in fin-desiècle Britain and the two decades that followed. ${ }^{74}$ Oil took on an almost mythological quality during the period, and was frequently represented as a powerful and potentially limitless source of energy. Oil appeared as an abiogenesis, a spontaneous outburst of organic matter that held the power to revolutionize the world. Benjamin J. Crew asserted in 1886 that the "welcome, cheerful, steady flame of petroleum" in Britain "promoted the happiness and comfort of the multitudes," and had added to the "sum of human knowledge" as a result of the countless number of hours "snatched from darkness and sleep." 75 The novelty of oil, mixed with its transformative effect on daily life, led many Britons to imagine oil as a modern resource, one that represented a distinct break from the traditional resources of the past.

\footnotetext{
${ }^{71}$ Dodds Henry, 1905, ix, 6. Henry included a chapter entitled "Romance of Oil Field Finance," which asserted that one could uncover "a wealth of romance in the finance of oil" (51).

${ }^{72}$ For examples, see J. Dodds Henry, "Oil Fields of the Empire," The Times, 15 January 1908, 4; J. Dodds Henry, "The Manufacture of Petrol," The Times, 11 March 1908, 3; J. Dodds Henry, "Oilfields of Canada," The Times, 21 August 1908, 13; J. Dodds Henry, "Oilfields of New Zealand," The Times, 16 August 1911, 19.

${ }^{73}$ H. Russell, "The Romance of Oil," Western Morning News, 21 November 1922, 4.

${ }^{74}$ R. Barrett and D. Worden, "Introduction," in Oil Culture, 2014, xxv.

${ }^{75}$ Benjamin Crew quoted in J. Dodds Henry, Thirty-Five Years of Oil Transport, 1907, 27, 40.
} 
Oil was perceived as a more efficient, cleaner, and more powerful form of energy than coal. In 1921, the Illustrated Sporting and Dramatic News held up the old view that "One has imagined hitherto...that oil getting is a filthy, ugly process which utterly disfigures the landscape, and one wonders how anybody could pursue it without taking to drink," and then proceeded to argue that the opposite was true. On a modern oil rig, "everybody dresses neatly and seems to cultivate cleanliness, and untidiness is nowhere to be seen," and in the refineries where crude oil was processed, workers conducted their business in "vast, modern, sanitary and spacious" facilities. ${ }^{76}$ An article published in the Illustrated London News in January 1922 concluded that, in the "Age of Petrol," Britons had become "cleaner and more orderly." 77 Oil was described as a youthful, vigorous, and virile substance, and metaphorical representations often featured characters such as young princes or powerful animals. This oil mentality can be found in a speech delivered by H.B. Heath Eves, a senior employee of the Anglo-Persian Oil Company, at the christening of the BP oil tanker, British Colony: "oil is so admirably adapted by its economy and efficiency, by its tremendous concentration of power in small bulk...that it is now an essential of progress and development - almost of civilization." ${ }^{.78}$ There was a pervasive sense of optimism about oil, and consumers were encouraged to become modern through their use of oil products. Oil could make the modern world possible, many believed.

\footnotetext{
${ }^{76}$ Illustrated Sporting and Dramatic News, 13 December 1921, 32, 50.

77 "Books of the Day," Illustrated London News, 14 January 1922, 44.

78 "Launch of the British Colony," Naft 3, no. 3 (May 1927): 7. The ship displaced 7,000 tons and was launched at Walker-on-Tyne. It was sunk in May 1942 by a German U-boat off the coast of Barbados. "British Colony," U-Boat.net. Retrieved from: www.uboat.net/allies/merchants/ships/1654.html.
} 
The advent of oil in Britain, apparently overnight and affecting every facet of daily life, was envisioned as the leading edge of a sea change in energy consumption habits - a tidal wave of oil washing over Britain, changing it irrevocably. Critics of oil resisted the transformation. The British conservationist, Clough Williams-Ellis, decried the social and cultural changes brought about by oil in his 1928 publication, England the Octopus: "Everyone who reads this book, indeed, everyone who reads at all or has eyes in his head," he wrote, "knows that England has changed violently and enormously within the last few decades." 79

The rise of oil appeared as a direct challenge to the dominance of British coal, and the worldwide network of port facilities, coaling stations, and transportation vessels that had been used to create, expand, and sustain the British Empire during the previous century. In the eyes of many coal supporters, primarily in Britain's coal mining regions, the turn to oil was a catastrophic mistake that would bring economic, political, and social instability to the British Isles, and even threaten its national security. ${ }^{80}$ According to Cardiff's Western Mail, the largest local daily newspaper in Wales, the widespread use of oil had been "a grave national blunder," which had turned Britain's coal industry into a

\footnotetext{
${ }^{79}$ C. Williams-Ellis, England the Octopus (Portmeirion: Golden Gragon, 1928): 15. Williams-Ellis was an architectural critic and frequent commentator on oil infrastructure in the English countryside. See C. Williams-Ellis, The Architect (London: G. Bles, 1929); C. Williams-Ellis, Britain and the Beast (London: Dent, 1938); C. Williams-Ellis, Plan for Living: The Architect's Part (London: Faber and Faber, 1941). ${ }^{80}$ Scholars from other countries also identified a shifting energy landscape. As the French oil expert, Pierre de la Trameyre, predicted in 1921: "We are just entering upon an economic period which will turn the whole world upside-down - the Revolution in Fuel, with its far-reaching consequences." In 1925, the Danish oil scholar, Anton Mohr, observed that Britain was entering into a "world-wide fight for oil," while the American oil journalist, Louis Fischer, warned in 1926 that "the history of the next generation or two will be read in the light of the struggle for oil." P. de la Tramerye, La Lutte Mondiale pour le Pétrole [The World-Struggle for Oil] (London: George Allen \& Unwin, 1921 [1927]): 19; A. Mohr, The Oil War (London: Martin Hopkinson, 1925): 29; L. Fischer, Oil Imperialism: The International Struggle for Petroleum (London: Allen \& Unwin, 1926): 245; "Fischer, Louis, 1896-1970," Princeton University Library Finding Aids. Retrieved from: www.findingaids.princeton.edu/names/73845816.
} 
"pathetic disaster" that was engaged in a "desperate fight for life." 81 David Davies, president of the Ocean Coal Company, reflecting on the 1930 fiscal year at his annual address to company shareholders, claimed that it had been "one of the most disastrous on record," largely as the result of a decline in coal consumption. He lamented to his audience that the period would be remembered as one of "grievous disappointment." 82 The economic situation was so severe in Britain's coalmining communities during the early 1930s that the editors of the industry's national trade magazine, the Colliery Guardian, questioned whether the country could "emerge from the imbroglio intact." 83

Despite a persistent chorus of disapproval directed towards the transition to oil, the overwhelming majority of contributors to British oil discourses treated the expanding use of the resource as a positive development and, indeed, one that promised to improve the lives of everyone, everywhere. A common theme in British petrocultural discourse during this time was excitement over the energy transition to oil, and the opportunities that the resource offered for industry, transportation, social mobility, national wealth, and personal happiness. Boverton Redwood, the British chemist and oil industry consultant, provided an account of the drama of oil drilling in his 1886 Cantor Lectures, "Petroleum and Its Products," in which he described a newly drilled well "throwing up a stream of oil" at a rate of one million gallons per day. "When oil is struck," he said, the outrush was "so violent that the ponderous drilling tools are projected from the well" and blown apart

${ }^{81}$ Western Mail, 1 April 1931, 6.

${ }^{82}$ D. Davies, "Christmas Message," Ocean and National Magazine 3, no. 12 (1930): 1; D. Davies, "Our Chairman's Xmas Message," Ocean and National Magazine 4, no. 12 (1931): 383. The editors of the Colliery Guardian trade journal echoed Davies's bleak outlook on the British coal industry, and described 1930-1931 as a "cynosure," and "another of those black pages in the history of the British coal mining industry." Colliery Guardian, 2 January 1931, 45; Colliery Guardian, 1 January 1932, 24.

${ }^{83}$ Colliery Guardian, 2 January 1931, 47. 
by the enormous force of the "magnificent fountain" of petroleum ${ }^{84}$ Another British chemist and oil expert, Vivian Lewes, remarked in a lecture delivered to the Incorporated Gas Institute that "nothing had been more remarkable than the marvellous growth in our scientific knowledge... of the manufacture and burning of gas." ${ }^{" 85}$ Welcoming the changes that oil was bringing about, these and likeminded voices injected information, stories, and ideas into British energy debates.

The transition to the modern Age of Oil was the most frequent narrative construct used in the making of British petrocultures. As early as 1889, Charles Marvin, the British energy polemicist and expert on Russia and on oil, was predicting an oncoming energy transition to oil, and he warned audiences in numerous articles, pamphlets, and books that the world must prepare for an energy "revolution," a transition to a distinct period of global history in which Britain would play "its proper part" - the role of "Boss" in the "Coming Oil Age." ${ }^{\prime 86}$ Marvin was certainly ahead of his time, and was only one of a handful of people then thinking that way. Coal was, after all, still the preferred source of energy in most places. But during the early twentieth century the notion of transition to an Age of Oil came to the fore. In 1901, Boverton Redwood confided to his colleague and fellow oil enthusiast, James Dodds Henry: "It is my firm conviction that the birth of

\footnotetext{
${ }^{84}$ B. Redwood, Cantor Lectures on Petroleum and Its Products (London: Trounce, 1886): 8, 28-29.

${ }^{85}$ V. Lewes, "A Century of Work on the Development of Light from Coal Gas," The Times, 17 June 19, 3. ${ }^{86}$ C. Marvin, The Coming Oil Age: Past, Present \& Future (London: R. Anderson, 1889): 32. Charles T. Marvin was a prolific writer on matters related to Russia and, toward the end of his career, on oil. For examples, see C. Marvin, The Petroleum Question: The Coming Deluge of Russian Petroleum (London: R. Anderson, 1886); C. Marvin, The Petroleum Question: England as a Petroleum Power (London: R. Anderson, 1887); C. Marvin, The Petroleum Question: Our Unappreciated Petroleum Empire (London: R. Anderson, 1889); A. Yefimov, "Russian Oil in the Eyes of a Briton," Oil of Russia 3 (2005). Retrieved from: www.oilru.com/or/24/414; G. Boase, "Marvin, Charles Thomas (1854-1890)," Oxford Dictionary of National Biography (London: Oxford University Press, 2006).
} 
the new century synchronises with the inception of the age of petroleum as a source of power in a wider and more enlightened sense than is commonly realised." 87

In the contemporary literature, a sense of optimism and excitement about oil pervades, and one can sense the anticipation of its transformative effects. As Dodds Henry noted in his 1908 book, Oil Fuel and the Empire, there was "a decided change" in attitudes toward oil "with the advent of the century." 88 In April 1901, the Petroleum Review wrote that there was "no reason why the adoption of liquid fuel should not become very widespread within a very short space of time." 89 The Chairman of the G. M. Oil Fields Company, George Macdonald, told his shareholders in 1911 that the "age of oil was only just beginning," and that in five years' time, it would be "a rare thing to see a horse-cab in London." ${ }^{90}$ In 1912, the same magazine updated its forecast, declaring that Britain was at the threshold of an "oil fuel age." $" 91$ William Antrobus, a Manchester engineer, asserted in 1913 that "[ $\mathrm{t}]$ here is no mistaking the fact that we are on the verge of an oil age." ${ }^{92}$ According to a special article published in The Times by the AngloAmerican Oil Company, the "day of oil is at hand. We are on the threshold of the great oil era." 93

\footnotetext{
be the age of oil." J. Dodds Henry, 1908, 154, 168.

${ }^{89}$ Petroleum Review, April 1901, quoted in G. Jones, 1978, 139.

90 “The G.M. Oil Fields (Limited)," The Times, 6 May 1911, 25.

${ }^{91}$ Petroleum Review, 5 October 1912.

92 Antrobus, 1913, 7.

93 "Petroleum Fuel Products," The Times, 1 December 1913, 47.
}

${ }^{87}$ J. Dodds Henry, Thirty-Five Years of Oil Transport (London: Bradbury Agnew, 1907): 147.

${ }^{88}$ J. Dodds Henry, Oil Fuel and the Empire (London: Bradbury Agnew, 1908): 137. Henry also includes several passages quoting prominent individuals expressing optimism about oil. According to the founder and Chairman of the Shell Transport and Trading Company, Marcus Samuel, oil appeared to have an "enormous future," while the American oil scholar and Chairman of the California State Mining Bureau, Charles Tenison Deane, prophesized that if "the nineteenth century was the coal age, the present one will 
Others were convinced that the Age of Oil had already arrived. According to the British oil journalist, Frederick Talbot, oil had led a "Conquest of the World," and in his 1914 book of that title, he asserted: "While the nineteenth century will be known to history as the Coal Age, the twentieth century will go down to posterity as the Oil Era."94 By the early interwar years, representations of the Age of Oil (and its synonyms, including Age of Petrol, Oil Age, Oil Era, and Day of Oil) were nearly ubiquitous in British energy discourses. ${ }^{95}$ Albert Lidgett, for example, concluded in 1919 that "we today live in an age of oil, for the products of petroleum are inseparable from our daily life." 96

Newspapers and magazines were crucial mediums for constructing and sharing oil narratives. In articles such as "An Age of Oil," published in the Yorkshire Evening Post in September 1919, "The Age of Oil Fuel," in the Cornishman in March 1920, or "The Petrol Age," in the Hull Daily Mail in July 1924, British readers learned of the new products and technologies that were being made available because of the development of oil. ${ }^{97}$ The Times and the Illustrated London News were particularly active in sharing news

${ }^{94}$ F. Talbot, The Oil Conquest of the World (London: Heinemann, 1914): 1.

95 The narrative of transition to a modern age of oil was pervasive in the literatures of other countries during the period of study, particularly in Canada, France, and the United States. The American oil scientist, J.T. Henry, predicted in 1873 that a "new day is dawning - a day which is witnessing the birth of an idea that will give new direction to human thought and develop and industry which will forever mark an era in the progress of the world." In 1921, the French oil expert, Pierre de la Tramerye, argued that the world had arrived "at the dawn of the great "Age of Oil." J. Henry, History and Romance of the Oil Industry (Philadelphia: James B. Rogers, 1873): n.p.; P. de la Tramerye, La Lutte Mondiale pour le Pétrole [The World-Struggle for Oil] (London: George Allen \& Unwin, 1921 [1927]): 74. Several periodicals dedicated to the age of oil theme were founded in the United States during the period, including Petroleum Age (Bradford, PA, 1892); National Petroleum News (Cleveland, OH, 1909); Oil Age (Los Angeles, CA, 1910); Oil and Gas Journal (Tulsa, OK, 1910); Oildom (Bayonne, NJ, 1911).

${ }^{96}$ Lidgett, Petroleum, 1919, iii.

97 "An Age of Oil," Yorkshire Evening Post, 20 September 1919, 6; "The Age of Oil Fuel," Cornishman, 24 March 1920, 5; “The Petrol Age,” Hull Daily Mail, 10 July 1924, 3. S. For additional examples, see "The Oil Age," Gloucestershire Chronicle, 4 June 1910, 3; "Is the Oil Age at Hand?" Yorkshire Evening Post, 4 June 1912, 6; "The Oil Era and Its Portents," The Motor, 8 July 1913; "The Age of Oil," Pall Mall Gazette, 10 June 1914, 4; "The Oil Age," Northern Whig, 16 July 1917, 3; "The Oil Age," Sheffield Independent, 21 May 1921, 9; "The Oil Age," Birmingham Daily Gazette, 23 September 1925, 4; "Looking 
and stories about oil, both in Britain and around the world, often accompanied by visual aids such as photographs, illustrations, and painted artwork. ${ }^{98}$ An article on "The Problems of Coal," published in The Times in July 1919, conceded that the "present is an age of oil fuel," and that the "motor vehicle is a necessary adjunct of civilization.",99 When the White Star liner, Olympic, set sail from Southampton in June 1920, The Times celebrated the vessel as "the first of the greatest liners to burn oil instead of coal." The great ship had been launched in 1910 as a coal-burner, and converted to burn oil in 1919: "This is, as one of the engineering experts on board the ship expressed it, an Oil Age."100 A Times special correspondent wrote in 1921 that the "dawn of the oil age has been announced."101 An advertisement in the Illustrated London News for Pratt's "Perfection" Spirit informed readers that human history had unfolded in a series of ages - "the stone age, the iron age, the coal age and the greatest era of all - the Great Oil Age."102

Speaking, lecturing, and performing were also very important means of communicating ideas about the Age of Oil to British audiences. The Chairman of the Trinidad Dominion Oil Company told his shareholders in 1919 that "the present time might truly be described as the real beginning of the oil age." ${ }^{103}$ A four-act play

to the Next Oil Age," Aberdeen Press and Journal, 23 September 1925, 5; "End of Petrol Age?” Daily Herald, 17 July $1930,3$.

${ }^{98}$ For examples, see "The Age of Faith and the Age of Petrol," Illustrated London News, 23 September 1911, 500; "Signs of the Age of Petrol," Illustrated London News, 27 September 1913, 472; "Art

Exhibitions," The Times, 23 March 1914, 1; “The Empire in the Oil Age," The Times, 27 July 1920, 16; "Rural Crafts in the Age of Petrol," The Times, 24 November 1930, 18.

99 "The Problems of Coal," The Times, 14 July 1919, 17.

100 "Olympic of the Oil Age," The Times, 21 June 1920, 16; D. Gray, "Carrying Canadian Troops: The Story of RMS Olympic as a First World War Troopship," Canadian Military History 11, no.1 (2002): 5470; M. Chirnside, The Olympic-Class Ships (Stroud: Tempus, 2004): 103.

101 "The Decline in Oil," The Times, 3 February 1921, 16.

102 Pratt's Spirit, “The Great Oil Age," Illustrated London News, 10 September 1921, 344. The advertisement asserted that, "at last man has learnt to use the tremendous latent energy of petroleum - that energy which has lain for countless ages in the bowels of the earth." The message delivered at the bottom of the advertisement: "there is a great deal of true romance in Pratt's 'Perfection' Spirit."

103 "City News in Brief," The Times, 8 October 1919, 15. 
performed in London, called "The Right to Strike," included the following lines, spoken by a medical student complaining about a lingering coal miner's strike: "We've got 'em beat, my boy. This is the age of petrol." 104 The Prince of Wales delivered a speech to the Royal Automobile Club, on the occasion of its $25^{\text {th }}$ anniversary in 1922. He enthused that the event had reminded him of how "very fortunate" he was to have been living in the present time: "I mean being born at the beginning of a new age, the age of petrol and automobility...I am bold enough tonight to prophesy that in time to come the beginning of this age... will be hailed by historians as marking the start of a new era of very great importance in the march of civilization." 105 Oil scientist J. S. Brame delivered a lecture on the subject of "Petroleum in the Service of Man," at an event held at the Fulham Town Hall, in which he detailed the history of the "oil age," going back to Biblical times and the Tower of Babel, and continuing into the late nineteenth and early twentieth centuries, when "mineral oil had almost revolutionized the world." 106 In 1928, an editorial published in the Naval Review by the pseudonymous author, "Poseidon," observed that it had become "a matter of common habit...to speak of the 'Air Age,' the 'Wireless Age,' the 'Oil Age,' and, embracing all, 'the New Age."”107 Excitement about oil, critics darkly remarked, amounted to a "breaking out of a mental disease."108

Sources and Methodology

\footnotetext{
104 "The Right to Strike," Illustrated London News, 27 November 1920, 886.

105 "New Transport Era," The Times, 9 December 1922, 8.

106 "The Oil Age," The Times, 10 March 1925, 10. For additional examples, see J. Cadman, "The Oil Era and the British Empire," Naft 3, no. 2 (March 1927): 11; "Mr. Churchill on His Budget," The Times, 26 April 1928, 18.

107 "Poseidon," "In Bondage to Oil," Naval Review 16, no. 4 (November 1928): 769.

${ }^{108}$ I. Lubin and H. Everett, The British Coal Dilemma (London: Allen \& Unwin, 1927): 1.
} 
The dissertation is founded upon extensive primary sources and has employed a multi-archival research strategy targeting a variety of private, local, national, and corporate archives in Britain and in Canada. It incorporates traditional archival materials, such as newspapers, magazines, books, and official documents, as well as sources drawn from popular culture, including cartoons, artwork, maps, advertising, public lectures, exhibitions, and architecture. In the United Kingdom, materials were consulted in Birmingham, Coventry, Warwick, Aberystwyth, Swansea, Cardiff, and Portsmouth, and in Canada, archives were visited in Calgary, Toronto, and Ottawa. Collections of local, regional, and national newspapers and news clippings were consulted at the Birmingham Cadbury Research Centre and the University of Birmingham, and in the Glamorgan Archives and Cardiff Central Library, both in Cardiff. News reports and analysis were also seen at the British Petroleum Archives, housed at the University of Warwick. Online newspaper archives were particularly pertinent to this study, including The Times, the Illustrated London News, and the Manchester Guardian, as well as the many titles available through the British Newspaper Archive. Magazines and trade journals, such as Commercial Motor, Grace's Guide to Industrial History, and Punch have also been examined through online databases.

A crucial source for this study has been the substantial body of historical British monographs on the subject of oil, written by authors William Antrobus, James Dodds Henry, Vivian Byam Lewes, Albert Lidgett, Marcel Mitzakis, Sydney North, Sir Thomas Boverton Redwood, Frederick Talbot, and J. W. Williamson. The majority of these books were consulted at Birmingham University Library, the location of the first university petroleum engineering programme in Britain, and home to a specialist collection of 
historical oil monographs. Other titles were examined at the Carleton University Library, Ottawa, and at the National Library of Wales, in Aberystwyth. Online databases, including Empire Online, Google Books, Hathi Trust, and the Internet Archive proved invaluable.

Corporate archival materials are integral to this dissertation, particularly those of the Anglo-Persian Oil Company (APOC) and the British Petroleum Company (BP). Official records, photographs, advertising materials, and several other fonds were viewed at the West Glamorgan Archives, the Richard Burton Archives, the Neath Antiquarian Society, and the Swansea University Library, all in Swansea, Wales. The greater part of the corporate research for this study was undertaken at the University of Warwick, in Coventry, which houses the BP corporate archives. At a public lecture in 2001, the head archivist at BP, Michael Gasson, quoting Yergin's The Prize, mused that "[i]t is often suggested that the twentieth century...has been completely transformed by the advent of petroleum." He continued: "If that is the case, then the holdings at BP Archive constitute a major part of the record of that process, and certainly the major part that is accessible to the public." 109 BP's holdings include executive board meeting minutes, company memoranda and correspondence, staff magazines, and a large collection of artwork, photographs, and advertisements. The archives also hold a sizeable collection of film and video materials, and a specialist library with dozens of rare and unpublished titles. Other sites of interest included the South Wales Miners' Museum, in Swansea, and the Glenbow Archives, in Calgary, both of which hold historical pamphlets related to coal and oil.

${ }^{109}$ M. Gasson, “Archives for Business History: the BP Archive,” Business History News (October 2001): 7. 
The dissertation is organized into four chapters, each of which presents a detailed case study of a major figure or company active in British oil discourse during the seventy year period from 1865 to 1935 . These case studies expose four key episodes in the cultural history of oil in Britain and offer valuable entry points into the creative accounts and imaginative spectacles that were used in the making of British petroculture. The chapters are chronologically ordered and thematically structured. The first two chapters examine the histories of individuals who played a prominent role in the transition to oil in Britain. Chapter One follows the professional career and public life of analytical chemist and oil expert, Sir Thomas Boverton Redwood. Despite Redwood's pioneering role in the historical development of oil science and technology in Britain, and his massive contribution to the literature and discourse of oil during the period, virtually no scholarly attention has been paid to him or his career. This chapter works to situate Redwood's contribution to British oil discourses within the larger history of oil and energy transition in Britain during the period of study. Using a variety of primary source materials, including newspapers, magazines, books, and lectures, many of which have not yet been examined by historians, the chapter argues that Redwood played a central and hitherto unexamined role in the development of the earliest petrocultures in Britain. Over the course of his career, Redwood developed the key narratives of modern technology and the transition to the Age of Oil that came to define British oil imaginaries.

Chapter Two explores the history of oil in Britain through the lens of the political cartoon. The work of British cartoon artist Leonard Raven-Hill is employed as a vehicle for accessing these histories, specifically two case studies of cartoons published in Punch magazine: "A Second String" (1912) and "Black Magic; or the New King Coal" (1933). 
These cartoons are historical documents capturing Britain's early-twentieth century transition from a predominantly coal-fuelled way of life to one increasingly powered by oil. They represent the emergence of oil as an exciting new source of fuel, heat, and motive power and, at the same time, the frustration and anxiety that many Britons felt about the British coal industry. What stories and ideas about oil does Raven-Hill convey? What do creative documents such as this tell energy historians about the past, and how might they be used to reconstruct previous experiences and interpretations related to oil? The chapter addresses these questions using Daniel Barrett and Ross Worden's notion of an oil spectacle as a frame of analysis, and argues that the anthropomorphosis of energy into imaginary characters such as King Coal and Prince Petroleo helped Britons to make sense of the enormous complexity of Britain's changing energy landscape. Through these characters, the ideas that constituted the energy transition to an Age of Oil were given form and identity, and emplotted on a narrative framework of conflict and industrial conquest.

The second half of the dissertation turns to an analysis of materials related to two British oil companies and their roles in effecting the transition to oil in Britain. Chapter Three focusses on the formative years of the Anglo-Persian Oil Company (APOC) over the period 1909-1925. Using the company's first British oil refinery as a case study - the Llandarcy Refinery, completed in Wales in 1922 - the chapter traces the ways in which APOC communicated information about oil to targeted British audiences. Specifically, it reconstructs APOC's publicity activities relating to the Llandarcy Refinery in order to shed light on the company's vision of oil and Britain's future, and to map the different communities with whom this imaginary was shared. Using a variety of primary source 
materials consulted at the BP archives, including advertisements, photographs, pamphlets, company Board Room minutes, and newspaper and magazine reportage, the chapter demonstrates how the Llandarcy Refinery was represented not only as the means by which Britons were provided with oil products, but as a powerful edificial symbol of the transition to the modern Age of Oil. The aim of this chapter is to demonstrate the significant contributions that APOC promotional activities made to the tapestry of early British petroculture during the early twentieth century.

The fourth and final chapter investigates the motor spirit marketing activities of the British Petroleum Company during the period 1919-1925. Although BP is Britain's second-largest oil company (after Royal Dutch Shell) and one of the largest in the world, there are no studies that concentrate on the company's early advertising campaigns. The advertisements of larger oil companies like Anglo-American and Shell-Mex have been assessed by several historians, but BP remains to be studied. The chapter traces the evolution of the company's marketing activities from their modest beginnings in the immediate post-war years to the expensive, multi-dimensional publicity campaigns of the mid-1920s, which culminated in the Persian Khan exhibit presented at the British Empire Exhibition of 1924-1925. Using a wide range of primary sources consulted at local, national, and corporate archives in England and Wales, the chapter reveals the ways in which BP used imaginative marketing materials to create an "oil spectacle" in the minds of British consumers.

These disparate forms of expressing ideas about oil constituted a distinctly British petroculture during the late nineteenth and early twentieth centuries. The construction of this petroculture and its change over time is the central preoccupation of this dissertation. 


\section{Chapter One \\ An Expert of the Oil Age: Sir Thomas Boverton Redwood and the Development of Oil Science in Britain, 1869-1919}

This chapter investigates the professional career and public life of the analytical

chemist, Sir Thomas Boverton Redwood. ${ }^{110}$ Notwithstanding Redwood's significant

contribution to early oil science in Britain, there have been few scholarly investigations

of his work. This dearth of description and analysis may have arisen in the absence of any

known collection of private papers. ${ }^{111}$ Redwood wrote the first two textbooks on oil to be

published in Britain and invented a widely-used tool for measuring oil viscosity. ${ }^{112}$ Yet,

he does not appear in Findlay's 1937 classic, A Hundred Years of Chemistry, or in

Findlay and Mills' British Chemists (1947). His absence from Farber's 1,600-page tome,

Great Chemists, is similarly conspicuous. ${ }^{113}$ The lack of attention paid to Redwood in the

${ }^{110}$ T. Corley, "Redwood, Sir (Thomas) Boverton, first baronet (1846-1919)," in David Cannadine (ed.), Oxford Dictionary of National Biography (Oxford: Oxford University Press, 2004).

${ }^{111}$ In the autobiography of British oil expert Arthurs Beeby-Thompson, there is some discussion of personal materials and of conversations between the author and Boverton Redwood. A. Beeby-Thompson, Oil Pioneer (London: Sidgwick and Jackson, 1961); P. Logan, "Arthur Beeby-Thompson: Oil Pioneer," GEOExPro 14, no.3 (2017): n.p.. There is also mention of brief correspondence between Redwood and American geologist, F.E. Warren, in G. Gressley, "The French, Belgians, and Dutch Come to Salt Creek," Business History Review 44, no.4 (1970): 498-519. In Rory Miller's study of the Peruvian company, Lobitos Oil, there are also references to a brief correspondence between Redwood and the British geologist, E.R. Blunderstone. R. Miller, "Small Business in the Peruvian Oil Industry: Lobitos Oilfields Limited before 1934," Business History Review 56, no.3 (1982): 403.

${ }^{112}$ Sorkhabi identifies the first two textbooks as B. Redwood, Cantor Lectures on Petroleum and Its Products (London: Trounce, 1886), and B. Redwood, Petroleum (London: Charles Griffin, 1896). In Sorkhabi's article, Redwood is accorded recognition as one of Britain's first scientific authors, but there is no discussion of his contributions beyond these two texts. On the history of early oil science textbooks, see F. Plummer, "Progress in Petroleum Geology," AAPG Bulletin 5, no.3 (1921): 413-416; R. Sorkhabi, "Early Textbooks of Petroleum Geology," GEOExPro 8, no.6 (2012); R. Sorkhabi, "A History of Petroleum Geoscience Textbooks," Oil Industry History 16, no.1 (2015): 165-208.

${ }^{113}$ A. Findlay, A Hundred Years of Chemistry (London: Gerald Duckworth, 1937); A. Findlay and W. Mills, British Chemists (London: The Chemical Society, 1947). The absence of Redwood is also noticeable in B. Jaffe, Crucibles: The Lives and Achievements of the Great Chemists (New York: Tudor, 1930), and E. Farber, Great Chemists (London: Interscience, 1961). 
history of British science and technology is particularly surprising, since there have been several studies of American and Canadian oil experts who were his contemporaries. ${ }^{114}$ In the literature on the history of oil in Britain, Redwood is ascribed prominent roles as an oil scientist and in-demand consultant on new oil research and development projects. ${ }^{115}$ J. R. L. Anderson's history of British oil companies and their activities in the Middle East, B. S. McBeth's study of British overseas oil policy, and I. Varcoe's article on official scientific research during the First World War are three examples of research that mention Redwood's participation in the early history of oil in Britain. It is noteworthy however, that none of these studies provides any analysis of Redwood's activities beyond his corporate and political consulting work. ${ }^{116}$ In Marian Kent's history of oil during the period 1900-1920, Redwood appears once. ${ }^{117}$ Berry Ritchie's illustrated history of the British Petroleum Company, Portrait in Oil, makes several references to Redwood's leadership in the discovery of oil in Persia, and in the development of the Anglo-Persian Oil Company (later BP). But Ritchie stops short of any discussion of

\footnotetext{
${ }^{114}$ For examples, see P. Lucier, Scientists and Swindlers: Consulting on Coal and Oil in America, 18201890 (Baltimore: Johns Hopkins University Press, 2008); H. Black, "Dr. Abraham Gesner," in Canadian Scientists and Inventors (Markham: Pembroke, 1997); M. Sheppard, Oil Sands Scientist: The Letters of Karl A. Clark, 1920-1949 (Edmonton: University of Alberta Press, 1989).

${ }^{115}$ Although many histories of oil in Britain acknowledge Redwood, he does not appear in the following studies: S. Longrigg, Oil in the Middle East (London: Oxford University Press, 1968); D. Payton-Smith, Oil: A Study of War-Time Policy and Administration (London: Her Majesty's Stationary Office, 1971); M. Fletcher, "From Coal to Oil in British Shipping," Journal of Transport History 3, no.1 (February, 1975): 3; G. Jones, "The Oil-Fuel Market in Britain 1900-1914: A Lost Cause Revisited," Business History 20, no.2 (1978): 135; R. Massie, Dreadnought: Britain, Germany, and the Coming of the Great War (New York: Ballantine, 1991); R. Engdahl, "Oil and the Origins of the Great War," History Compass 5, no.6 (2007): 2041-2060; T. Winegard, The First World Oil War (Toronto: University of Toronto Press, 2016). 116 J. Anderson, East of Suez: A Study of Britain's Greatest Trading Enterprise (London: Hodder and Stoughton, 1969); B. McBeth, British Oil Policy, 1919-1939 (London: Frank Cass, 1985); I. Varcoe, "Scientists, Government and Organised Research in Great Britain 1914-16: The Early History of the DSIR," Minerva 8, no.1 (1970): 192-216.

${ }^{117}$ M. Kent, Oil and Empire: British Policy and Mesopotamian Oil, 1900-1920 (London: Macmillan, 1976). A reference to Redwood's work with the Petroleum Research Department during the First World War appears in Appendix VI. Kent does not include any references to Redwood in her bibliography.
} 
Redwood beyond his work as a scientific consultant to oil exploration and development companies. ${ }^{118}$

Another British oil scholar, Geoffrey Jones, has examined some elements of Redwood's career. In The State and the Emergence of the British Oil Industry, Jones identifies Redwood as "Britain's leading oil 'expert,", and a scientist who occupied a "position of great, if informal, influence, and in many ways" was "the eminence grise of British oil policy." 119 Yet Jones too focuses exclusively on Redwood's consulting work, first for "virtually every British oil company," and secondly for innumerable public officials and legislators. ${ }^{120}$ Jones's verdict that "Redwood's views on oil matters were relatively straightforward" appears almost dismissive, and does an injustice to the extensive endeavors undertaken by Redwood that went beyond business and politics. ${ }^{121}$ Jones's entry for Redwood in the 1985 edition of the Dictionary of Business Biography, co-authored with F. Goodall, contains some biographical facts and a detailed discussion of Redwood's service during the First World War, but little else. ${ }^{122}$ A treatment of Redwood is provided in R.W. Ferrier's The History of the British Petroleum Company. Although Ferrier does describe Redwood as Britain’s “ubiquitous petroleum plenipotentiary," and "the leading petroleum expert of the day," he provides no discussion of the scientist or of his role in the history of the company; instead, Redwood

\footnotetext{
${ }^{118}$ B. Ritchie, Portrait in Oil: An Illustrated History of BP (London: James \& James, 1995).

119 G. Jones, The State and the Emergence of the British Oil Industry (London: Macmillan, 1981): 4, 97.

${ }^{120}$ Jones, 1981, 4, 97. Jones specifically notes the close relationship between Redwood and Winston Churchill, John Arbuthnot Fisher, William Knox D’Arcy, Marcus Samuel, and John Rockefeller.

${ }^{121}$ Jones, 1981, 98. This limited view may have arisen because Jones appears to have considered only one of Redwood's works, the fourth edition of Petroleum, which was published in 1922, three years after Redwood's death. Jones includes four works authored by himself. (Jones, 1981, 124).

${ }^{122}$ G. Jones and F. Goodall, "Redwood, Sir Thomas Boverton," in D. Jeremy (ed.), Dictionary of Business Biography (London: Butterworths, 1985).
} 
makes cameo appearances at intervals throughout the book, and is otherwise absent from the rest of the narrative. ${ }^{123}$

One of the few scholars to shine a light on the breadth of Redwood's activities is Daniel Yergin. In The Prize, Yergin describes Redwood as "Britain's premier oil expert," and as an accomplished scientist with global impact: "a man who had a profound influence on the course of international oil developments in the first two decades of this century." 124 Notwithstanding the claim that Redwood was "ever-present" in British oil affairs, Yergin provides only a superficial sketch of the scientist and his role in the early history of oil. ${ }^{125}$ There are no sustained discussions of Redwood anywhere in the text, and Yergin's overall portrait of Redwood is two-dimensional. ${ }^{126}$ More recently, T. Corley has written in the Oxford Dictionary of National Biography what appears to be the only piece that is dedicated exclusively to Redwood. Corley claims that Redwood was the "first (and only) petroleum consultant of his kind," and an educator who possessed the ability to communicate with "non-expert officials and businessmen alike in the technicalities of oil." ${ }^{\prime 27}$ Strikingly, Corley does not mention a single publication of Redwood's, or any of his many professional affiliations and activities. ${ }^{128}$

\footnotetext{
${ }^{123}$ R. Ferrier, The History of The British Petroleum Company, Vol. 1, The Developing Years, 1901-1932 (Cambridge: Cambridge University Press, 1982): 32, 105, 282, 400, 694. Ferrier introduces readers to Redwood in 1901, and thereafter the focus is exclusively on his political consulting activities. Ferrier's biographical entry for Redwood describes the man in bald terms as "petroleum advisor to HM Government. Adviser to W.K. D'Arcy, BOC, and APOC. Member, Royal Commission on Oil Fuel and Engines, 19121913. Technical Advisor to HM Government." (694).

${ }^{124}$ D. Yergin, The Prize: The Epic Quest for Oil, Money and Power (New York: Simon \& Schuster, 1992): 123.

${ }^{125}$ Yergin, 1992, 141. Yergin focusses the majority of his attention on Redwood's involvement with the Burmah Oil Company, the Anglo-Persian Oil Company, the Admiralty, and the British Government.

${ }^{126}$ Only one of Redwood's publications, Petroleum (1896), appears in Yergin's bibliography.

${ }^{127}$ Corley, 2004. Corley was the official historian of the Burmah Oil Company and author of History of the Burmah Oil Company, 1886-1924 (London: Heinemann, 1983).

${ }^{128}$ Corley based his short article on anecdotes published in Jones (1981), Ferrier (1982), Corley (1983), and several obituaries published in 1919.
} 
Britain's first oil expert thus remains an elusive figure in the existing literature, portrayed as an individual who took part in significant events, but one who remained in the background. There is, to date, no account of the numerous ways in which Redwood shared his knowledge and ideas about oil beyond the realms of commerce and politics, or of the diverse audiences with whom he shared his vision of oil. Furthermore, there is little research that examines the actual content of his publications, although several of them, notably Petroleum, were widely recognized to be authorities in the field. In short, only a fraction of Redwood's contribution to the history of oil in Britain has been examined by scholars.

What was Redwood's vision of oil? How was it crafted and in what ways did it change over time? What audiences, beyond the political and commercial realms, did he engage with during his career, and what messages about oil did he deliver? And what was Redwood's role in shaping larger conversations about the modern Age of Oil? In answering these challenging questions, this chapter turns to a diverse range of primary source materials. ${ }^{129}$ These offer a composite picture of Redwood's professional and public life, which can be used to recreate his vision of the Age of Oil. The ultimate aim of the chapter is to put forward a richer account of Redwood's contribution to the development of British imaginaries about oil during the period 1869-1919.

\section{The Petroleum Association and Redwood's Training in Analytical Chemistry}

\footnotetext{
${ }^{129}$ Primary sources have been consulted using the following archives and repositories: AAPG Databases; the British Library; the British Newspaper Archive; the Canadian Petroleum History Society Bibliography; Grace's Guide to Industrial History; JStor; the National Archives (London); the National Library of Wales; various ProQuest Databases; United Kingdom Parliamentary Papers; United States Congressional Papers; Welsh Newspapers Online; WorldCat catalogue.
} 
Thomas Boverton Redwood was born in London on 26 April 1846, the eldest son of a well-established family of pharmacists and pharmaceutical manufacturers. ${ }^{130}$ As a young boy and as a teenager, Redwood experienced the transformative effects of the second industrial revolution, a period in Britain's energy history marked by a series of rapid advances in science and technology, including the harnessing of electrical energy and, most importantly for this study, the discovery of oil as a source of fuel, heat, light, and power. ${ }^{131}$ Redwood was nineteen years old when "Colonel” Edwin Drake struck oil in 1859 in Titusville, Pennsylvania, an event widely recognized as initiating the modern oil industry in North America. ${ }^{132}$ After graduating from University College School, London, in 1862, Redwood worked as an assistant in the chemical laboratory of his father, a renowned professor of pharmacy, Theophilus Redwood. ${ }^{133}$ As Corley observed, from the moment Redwood came of age, his "future in pharmacy seemed to be determined."134

The exploitation and consumption of oil increased rapidly around the world in the years following Drake's discovery, and unsurprisingly a new network of scientists,

\footnotetext{
130 "Death of Sir Boverton Redwood," The Times, 5 June 1919, 17; Jones, 1981, 124.

${ }^{131}$ N. McCord and B. Purdue, British History 1815-1914 (Oxford: Oxford University Press, 2007): 487.

${ }^{132}$ Drake referred to himself as "colonel" in order to impress local bushmen on whose property he wished to drill for oil. P. Warde, Energy Consumption in England and Wales, 1560-2000 (Rome: Consiglio Nazionale delle Ricerche, 2007): 98; R. Barrett, "Picturing a Crude Past: Primitivism, Public Art, and Corporate Oil Promotion in the United States," in R. Barrett and D. Worden (eds.), Oil Culture (Minneapolis: University of Minnesota Press, 2014): 43-64. Edwin Drake is also cited as the founder of the modern oil industry in Jones, 1981, 1.

133 Theophilus Redwood was born in Boverton, Glamorganshire, in 1806. He was a professor at the Pharmaceutical Society of Great Britain, editor of the Pharmaceutical Journal, and the first President of the Society of Public Analysts. Redwood's mother, Charlotte Elizabeth, was the daughter of Thomas Morson, founder of London's earliest and largest pharmaceutical manufacturers. D. Whiffen, The Royal Society of Chemistry: The First 150 Years (London: The Society, 1991): 197; J. Slinn, "Morson, Thomas (18251908)," in D. Cannadine (ed.), Oxford Dictionary of National Biography (Oxford: Oxford University Press, 2004).

${ }^{134}$ Corley, 2008. At some point during the late nineteenth century, Redwood attended the Royal School of Mines, a fact reported in his obituary and corroborated by his attendance at a reunion dinner of former classmates. "Royal School of Mines," The Times, 27 February 1904, 11; The Times, 5 June 1919, 17.
} 
particularly chemists, emerged to understand the resource and its many by-products. ${ }^{135} \mathrm{In}$ September 1868, Redwood's mother died suddenly. ${ }^{136}$ This event would appear to have had a dramatic effect on his career choices and sense of his future. Within a year of his mother's death, Redwood left his father's laboratory and took up a position as Secretary of the Petroleum Association of Great Britain, a private advocacy and lobbying organization. ${ }^{137}$ The decision confounded his peers. His obituary in The Times noted "At that time the petroleum industry had barely emerged from its infancy... and some of [Redwood's] friends thought he had made the mistake of putting his faith in a future with scanty prospects." 138 Redwood's willingness to risk the promise of a career in the wellestablished field of pharmaceuticals to pursue one in the new science of petroleum is an early testament to his faith in oil. He was never a skeptic, as were many of his contemporaries. He was aware of oil's challenges and confident in the opportunities it provided for professional advancement.

The Petroleum Association was an ideal venue for Redwood to acquire the specialised knowledge and skills required to become a petroleum scientist. Although he had been hired as Secretary, Redwood played many different roles during his early years at the Association. He served as the head analytical chemist, which gave him access to a

\footnotetext{
${ }^{135}$ In 1858, 6,359 barrels of petroleum were produced globally, while in 1885 , the amount equaled more than 47 million barrels. Over the period 1858-1914, a total of 7.5 billion barrels of oil were extracted around the world. G. Jones, "The Oil-Fuel Market in Britain 1900-1914: A Lost Cause Revisited." Business History 20, no.2 (1978): 131-152, 135. On the development of the international oil industry during this period, see A. Lidgett Petroleum (London: Isaac Pitman, 1919): 159; M. Mitzakis, The Oil Encyclopaedia (London: Chapman, 1922): 394; J. Henry, Baku: An Eventful History (London: Constable, 1905): vi. 136 "Funeral of Dr. Redwood, of Boverton," Barry Dock News, 25 March 1892, 6.

${ }^{137}$ B. Redwood, "Letter to the Editor," The Times, 25 July 1871, 10. The Petroleum Association was formed in London in February 1864, to advocate for the "proper conduct of the petroleum trade, and particularly to provide authoritative and binding rules for sampling, testing and analysing, as well as the settlement of all differences that may arise." "Petroleum," Liverpool Mercury, 10 February 1864, 6; "The Petroleum Association," Public Ledger and Daily Advertiser, 26 October 1866, 2.

${ }^{138}$ The Times, 5 June 1919, 17.
} 
large new laboratory designed specifically for conducting experiments on petroleum. ${ }^{139}$

Here, he learned to test oil and its technical properties, specifically its flashpoint, density, and viscosity, rapidly earning him a reputation for excellence in the science of petroleum. These experiences provided Redwood with the core competencies of an oil expert, a foundation of learning that he would use for the remainder of his career. Later, in 1886, he invented an accurate and widely-used tool for testing the viscosity of oil, a device that became known as 'Redwood's Viscometer.' ${ }^{40}$ Through the Petroleum Association, Redwood also acquired knowledge and experience outside of the laboratory. In the 1870s and 1880s, he was dispatched to investigate promising oilfields in Russia, the United States, and Canada, journeys that provided him with a global view of oil. ${ }^{141}$ On numerous occasions during the late 1870 s, he provided expert testimony in jury trials dealing with oil, usually in defence of the oil industry, while at the same time he published letters in newspapers such as The Times, the London Evening Standard, and London Daily News,

\footnotetext{
${ }^{139}$ In a letter written to the editor of the London Daily News in June 1871, Redwood signed off as "Secretary and Consulting Chemist to the Petroleum Association."

${ }^{140}$ B. Redwood, Detection and Measurement of Petroleum Vapour in the Air (London: Crosby Lockwood, 1896). Redwood's Viscometer was displayed at an exhibition held at the British Association in Nottingham in September 1893. "The British Association," The Times, 21 September 1893, 6. A photograph of Redwood's Viscometer can be viewed through the online archives of the British Science Museum, item no. 1974-413. Redwood made several patents for oil testing processes during his lifetime. His first was for "improvements in the manufacture of gas for burning," received in 1874, when he was just 28; in 1877 Redwood co-patented a similar improvement with his father, Theophilus; in the early 1890s, he invented a method for testing the gravities of heavy fuel oils used by the Royal Navy, which became known as the "Admiralty Standard" test; shortly afterwards, he invented tools for measuring petroleum gas in the air, and for locating water trapped beneath oil in ships, called the Redwood Water Finder. London Gazette, 13 October 1874, 4701; London Gazette, 22 June 1877, 3793; M. Perkins, "Sir Boverton Redwood, Bart.," Journal of the Chemical Society 117 (January 1920): 467.

${ }^{141}$ In 1877, Redwood was sent to New York to inquire into methods of testing petroleum. During 18831884, he travelled to Canada, the United States, and southern Russia and, in 1886, he returned to Ontario and New England to inspect oil storage facilities. "Memorandum," The Times, 30 October 1877, 5; "Russian Petroleum," The Times, 3 February 1885, 8; "Obituary," Journal of the Royal Society of Arts 67 (13 June 1919): 495-496; G. Gressley, "The French, Belgians, and Dutch Come to Salt Creek," Business History Review 44, no.4 (1970): 498-519.
} 
attempting to allay public fears about oil safety and the threat of spontaneous

explosions. $^{142}$

Through his different roles in the Petroleum Association, Redwood received a

thorough education in petroleum science. His work brought him into contact with figures

representing a wide array of business and industrial professionals, legal experts, and

politicians, all of whom offered him opportunities to expand his networks of influence. ${ }^{143}$

Beginning in the 1880 s, he became an active member of several of Britain's most

prominent learned societies, including the Royal Society of Arts, to which he was elected

a Fellow in 1885, and the Society of Chemical Industry, to which he was elected Vice-

President in $1886 .{ }^{144}$ Redwood was elected a member of the American Chemical Society,

the Imperial Russian Technical Society, and the Liverpool Petroleum Association.

Redwood's involvement with these societies provided him with opportunities for sharing

information and ideas about oil with powerful groups interested in the resource and its

future, including scientists, politicians, diplomats, businessmen, investors, and hobbyists.

Through such engagement, Redwood participated in the fostering of a sense of

\footnotetext{
${ }^{142}$ Redwood testified in cases involving a burning oil cargo ship ("Burning of a Petroleum Vessel," London Evening Standard, 5 January 1871, 3); a ship explosion at Erith ("Petroleum and Petroleum Spirit," London Daily News, 18 October 1871, 3); a fatal oil explosion on a Royal Navy training ship ("The Goliath," The Times, 1 January 1876, 6); spontaneous explosions in public spaces ("Gunpowder and Petroleum," Leeds Mercury, 21 October 1874, 7); faulty oil lamp wicks (Pall Mall Gazette, 23 April 1884, 5), and a "petroleum fog” explosion ("Inquests," The Times, 13 January 1887, 6).

143 "Russian Petroleum," The Times, 3 February 1885, 8; A. Beeby-Thompson, Oil Pioneer (London: Sidgwick \& Jackson, 1961): 75-80. Redwood began to serve as consulting chemist to several oil companies during the early 1870s. "The Dartmouth Peat Coal Company," Western Morning News, 13 March 1873, 1; "Estimated Value," Dartmouth \& South Hams Chronicle, 14 March 1873, 4.

${ }^{144}$ B. Redwood, "The Russian Petroleum Industry," Journal of the Society of Chemical Industry 2, no. 4 (1885): 70; B. Redwood, Cantor Lectures on Petroleum and Its Products (London: Trounce, 1886): i. The Society of Chemical Industry was founded in 1880 by Lancashire chemist John Hargreaves, and at the time of Redwood's lecture it was the primary professional association of the British chemical industry (www.soci.org/about-us/history). In 1880, Redwood joined the Finchley and Friern Barnet Conservative Committee, offering some hint of his political persuasion. The constituency was later held by Margaret Thatcher from 1979-1990. "Middlesex Election," Hendon \& Finchley Times, 3 April 1880, 4; A. Farrant, "Sir Waldron Smithers and the Long Walk to Finchley," Economic Affairs 32, no.1 (January 2012): 43-47.
} 
community in Britain's growing body of oil enthusiasts, and developed a formidable network of professional and personal friendships. ${ }^{145}$

Beginning in the mid-1880s, Redwood started to branch out from the Petroleum

Association. A key component of Redwood's professional life during this period was public speaking on topics related to oil. ${ }^{146}$ One of his first subjects was connected to his travels. ${ }^{147}$ In February 1885, at the London headquarters of the Society of Chemical Industry, Redwood delivered a lecture on "The Russian Petroleum Industry." 148 The following year, on 8 March 1886, in the Great Room of the London headquarters of the Royal Society for the Encouragement of Arts, Manufactures, and Commerce (RSA), Redwood gave the Cantor Lectures on "Petroleum and Its Products." 149 This series was an annual event established in 1860 by the RSA, and according to The Times, featured prominent speakers "concerned with the broad industrial issues and the scientific

\footnotetext{
${ }^{145}$ In January 1881, Redwood was elected the Honorary Secretary of the Finchley Tricycle Club, which was later renamed the British Tricycle Association. Redwood acquired the reputation of a "wheel celebrity," known for his patronage of "that wide arena of wheel life." "Cycling Celebrities," Wheel World 24, no.4 (April 1882): 235-236. In 1884, Redwood stepped down from the position and was made an honorary Vice-President. "Tricycle Meeting," Windsor and Eaton Express, 4 June 1881, 3; "Finchley Tricycle Club," Barnet Press, 18 November 1882, 6; Athletic News, 9 January 1884, 7. Redwood's contemporaries in the science community included B. Paul, On Liquid Fuel (London: Royal Society of Arts, 1868); C. Stewart, "The Use of Petroleum as Fuel in Steamships and Locomotives." RUSI Journal 30 (1886): 927; C. Marvin, The Petroleum Question. England as a Petroleum Power, or the Petroleum Fields of the British Empire (London: R. Anderson, 1887); W. Anderson, "The Origin of Petroleum," Journal of the Society of Arts (20 September 1889).

${ }^{146}$ In February 1884, Redwood delivered a lecture to the Pharmaceutical Society of Great Britain, in which he explored "A Sample of Sophisticated Oil of Turpentine." This was followed up in August with a talk on the "Determination of the Percentage of Oil in Paraffin Scale," to the Society of Chemical Industry. "ToMorrow," Pall Mall Gazette, 5 February 1884, 5; B. Redwood, "The Determination of the Percentage of Oil in Paraffin Scale," Journal of the Society of Chemical Industry 3, no.8 (August 1884): 430-432.

${ }^{147}$ Redwood's first foray into public oil discourse occurred when he was nineteen, at a conversazione hosted by the Geologists' Association in 1866. Redwood spoke on "Petroleum and Paraffin in Connection with the Preservation of Animal Food." "Geologists' Association," London Evening Standard, 21 January 1865, 1; "Educational Works," Illustrated London News, 21 January 1865, 28.

${ }^{148}$ B. Redwood, "The Russian Petroleum Industry," Journal of the Society of Chemical Industry 2, no. 4 (1885): 70; "The Russian Petroleum Industry," Morning Post, 3 February 1885, 3; Public Ledger and Daily Advertiser, 4 February 1885, 8; Northern Whig, 5 February 1885, 3.

149 B. Redwood, Cantor Lectures on Petroleum and Its Products (London: Trounce, 1886); "City Notes," Pall Mall Gazette, 6 March 1886, 5. "Syllabus," Journal of the Society of Arts 34 (20 November 1885): 2.
} 
principles involved in some definite matter of public importance singled out from the arts and crafts." $" 150$ The lectures were intended to have a wide appeal and were usually given over the course of several evenings. This format permitted Redwood to build a long-form narrative of petroleum in all its facets.

The Cantor Lectures showcased the depth and breadth of Redwood's scientific knowledge of petroleum, as well as his ability to convey complex research findings to the non-specialist. The lectures were divided into four parts: Lecture I: "Historical Account of Petroleum, and of the Development of the Petroleum Industry" (8 March); Lecture II: "Production, Transportation, and Storage of Crude Petroleum" (15 March); Lecture III: "Manufacture of Petroleum Products" (22 March), and Lecture IV: "The Uses of Petroleum and Its Products" (29 March). The use of historical references was a prominent feature of "Petroleum and Its Products." Redwood opened the series with a discussion of Herodotus and the "earliest descriptive mention of petroleum" that appeared in The Histories, which featured accounts of the ancient "Persian fire-worshippers" of the Caspian Sea basin. ${ }^{151} \mathrm{He}$ explained other ancient uses of oil "centuries before the

\footnotetext{
150 "Societies and Institutions," The Times, 5 February 1913, 22. The Royal Society of Arts (RSA) was established by William Shipley in London in 1754. The organization hosted public lectures, awarded medals for outstanding achievement in the arts and sciences, and published the Journal of the Society of Arts. The RSA was an early leader in energy innovation. In 1815, a gas lamp was installed in front of the Society's headquarters and, later in the nineteenth century, oil lighting was installed in the interior rooms and corridors. The Cantor Lecture Series, established in 1860, was funded by the estate of Dr. Edward Theodore Cantor, a surgeon in the Indian Medical Service. H. Wood, The Story of the Royal Society of Arts (London: Murray, 1935): 11-23, 65; D. Allan, William Shipley: Founder of the Royal Society of Arts: A Biography with Documents (London: Hutchinson, 1968); RSA website, 2018. Retrieved from www.thersa.org.

${ }^{151}$ Redwood, 1885, 71. On the relationship between Herodotus and oil, see for example G. Rawlinson, et al. (eds.), History of Herodotus (London: Murray, 1862); “Ancient Ideas About Petroleum,” Leeds Mercury, 19 April 1902, 12; T. Holland, The Histories (New York: Viking, 2014). Herodotus is a foundational character in B. McBeth, British Oil Policy 1919-1939 (London: Cass, 1985), and D. Yergin, The Prize (New York: Simon \& Schuster, 1992). The 2018 Wikipedia page on the "History of the Petroleum Industry" begins with the statement, "Four thousand years ago, according to Herodotus..." Retrieved from: www.wikipedia.org/wiki/History_of_the_petroleum_industry.
} 
Christian era," including as an ointment and pharmaceutical product in ancient Egypt, as a source of fuel for the Chinese, and as an element in the religious ceremonies of Persian fire worshippers. ${ }^{152} \mathrm{He}$ discussed oil in the Old Testament and referred to a theory recently posited by Sir Lyon Playfair that biblical references to salt, such as that which encased Lot's wife, were in fact referring to asphalt. ${ }^{153}$ After reconstructing these early histories of oil, Redwood presented the audience with a stark juxtaposition of the "primitive methods" of acquiring and using oil in "remote ages," and the modern science and technology used for the same purposes in the late nineteenth century. ${ }^{154} \mathrm{He}$ described at length the advanced drilling techniques that had been employed in "Colonel" Drake's 1859 discovery of oil in Pennsylvania, and the rapid growth of new oil finds using similar methods. ${ }^{155}$

To make these impressions still more realistic, and to bring his narrative back from remote oilfields and into the lecture theatre, Redwood displayed a variety of different artefacts and samples related to his lecture on a table in front of the audience. These items, including vials of different petroleum products, pieces of rock ejected from a well blowout, a selection of oil-burning lamps, and scale models of oil refinery components, offered audiences first-hand experiences with the latest petrochemical

\footnotetext{
${ }^{152}$ Redwood, 1886, 1-2. The fourth lecture, on 29 March, also began with a history lesson: "We know, from the accounts given by historians who wrote prior to the commencement of the Christian era...that petroleum was used as an illuminant in remote ages" (58).

153 "Petroleum and Biblical Salt," New York Times, 29 February 1884; "Notes," Radical Review 2, no. 9 (12 April 1884): 1. Lyon Playfair (1818-1898) was an English chemist who taught at the University College School, London, and who later served on numerous Royal Commissions on agriculture, public hygiene, and international exhibitions. G. Gooday, "Playfair, Lyon, First Baron Playfair," Oxford Dictionary of National Biography (Oxford: Oxford University Press, 2004); W. Doyle, "Lyon Playfair," University of Edinburgh School of Chemistry. Retrieved from: www.chem.ed.ac.uk/about-us/history/professors/lyon-playfair.

${ }^{154}$ Redwood, 1886, 19, 58.

${ }^{155}$ Redwood, 1886, 19.
} 
technologies of the day. ${ }^{156}$ Redwood did not just tell the story of the rise of the modern Age of Oil - he also showed the audience what that meant by using illustrations and photographs, and displaying several examples of "very primitive" lamps acquired during his travels in India and Russia. ${ }^{157}$ Although he discussed at length the molecular composition of oil for any specialists present, he also explained how chemists and engineers had transformed the crude natural resource into refined agricultural fertilizers and pesticides, waterproofing, laundry detergent for clothes, and a myriad of other household goods. ${ }^{158}$

The central focus of Redwood's Cantor Lectures on "Petroleum and Its Products" was the narrative of transition to a new age of oil, in which the everyday lives of Britons were transformed by the "mighty stream of petroleum which is ever flowing from the earth to supply the daily increasing demand." ${ }^{\prime 59}$ At the leading edge of this transition, Redwood argued, was a flourishing of new science and technology, which had enabled the unlocking of apparently unlimited sources of natural energy, while also providing consumers with vastly improved lighting, heating and, particularly for wealthy Britons, auto-mobility. Although refined oil products had only begun to be used in Great Britain on a large scale, they had already exercised a "civilizing influence" on British society, made the "labour of mankind more productive," and elevated the "sum of human happiness." ${ }^{160}$ Redwood predicted an oil future that made for brighter, healthier, and

\footnotetext{
156 Redwood, 1886, 26, 46, 47.

157 Redwood, 1886, 59.

158 Redwood, 1886,85 .

${ }^{159}$ Redwood, 1886, 85. On the use of fluvial metaphors to describe oil, see M. Walonen, "“The Black and Cruel Demon' and Its Transformation of Space: Toward a Comparative Study of the World Literature of Oil and Place," Interdisciplinary Literary Studies 14, no. 1 (2012): 56-78; S. LeMenager, Living Oil: Petroleum and Culture in the American Century (Oxford: Oxford University Press, 2013).

${ }^{160}$ Redwood, 1886, 86.
} 
happier lives, one in which the British consumer effortlessly moved about in complete comfort, aided by a vast assemblage of modern tools. In the sweeping, millenarian arc of human history, he predicted, it would be oil that played the leading role in producing a truly modern civilization.

Redwood's Cantor Lectures on "Petroleum and Its Products" have not been fully examined by historians or placed within the broader context of contemporary British energy discourses and oil cultures. This is a critical omission because it was during this period in Redwood's working life that one can see him develop not only his interest in petroleum science, but also his craft in communicating scientific information to diverse audiences. Redwood's lectures during the 1880s made a mark. The Globe (Toronto), for example, seized upon the fact that the first lecture had provided "a historical account of petroleum," noting that Redwood had pointed out that "the valuable properties of this substance were undoubtedly well known" to ancient societies centuries before. ${ }^{161}$ But perhaps the most telling indicator of Redwood's emerging status as a premier oil expert was the attention he received in American oil circles. The Morning Journal and Courier, of New Haven, Connecticut, described Redwood as the "recognized authority on petroleum," and the scientist's research was reproduced in several official investigations and reports completed by the United States Congress, such as D. Day's “Mineral Resources of the United States" (1894) and F. Clarke's "The Data of Geochemistry" $(1908) \cdot{ }^{162}$

\footnotetext{
161 "The Events of the Week: Art, Literature \& Science," Globe, 13 March 1886, 6.

162 "Editorial Notes," Morning Journal and Courier, 20 February 1885, 1; "Fire and Building Regulations in Foreign Countries," Consular Reports, Vol. VII. (Washington: Government Printing Office, 1892); D. Day, "Mineral Resources of the United States," $53^{\text {rd }}$ Congress, 1894; F. Clarke, "The Data of Geochemistry," $59^{\text {th }}$ Congress, 1908.
} 
Petroleum and the Establishment of an International Reputation

During the fourteen year period from 1886 to1900, the total amount of oil

products consumed in Britain increased more than three-fold, largely as a result of the rapid expansion in the use of lighting, and transportation technologies such as kerosene lamps, gas appliances, marine motors, and automobiles. ${ }^{163}$ Redwood's career in the field of oil science, therefore, coincided with a widespread surge in the use of the resource, while at the same time his international experience in the countries from which Britain imported its oil meant that Redwood possessed a degree of practical experience and scientific knowledge few could match. ${ }^{164}$ On a number of occasions, Redwood provided expert testimony for criminal trials involving oil fires. According to a report of an 1890 trial published in The Times, Redwood educated a jury on the flammability of oil by filling a large glass vessel with invisible petroleum fumes. "He then applied a light to the vessel," the reporter recalled, "and there was instantaneously a brilliant burst of flames which completely filled the vessel and rose out of it, to the considerable astonishment of

\footnotetext{
${ }^{163}$ C. Divall, "Transport, 1900-1939," in Chris Wrigley (ed.), Companion to Early Twentieth Century Britain (London: Wiley-Blackwell, 2009); Department for Business, Energy \& Industrial Strategy (UK), Crude Oil and Petroleum: Production, Imports and Exports 1890 to 2015 (London: HMSO, 2016). ${ }^{164}$ Several companies used quotes from Redwood's lectures and publications to sell their products. The advertisements of Defries' Safety Lamps featured several comments made by Redwood in the Cantor Lectures on "Petroleum and Its Products." As one ad cited, the "risks attaching to the employment of mineral oil as illuminating agents in lamps... are non-existent in the use of Defries' Safety Lamps," while another carried Redwood's guarantee that the combustion of oil in these lamps was always "complete, neither smoke nor odour being produced." Several of these advertisements included the message, printed in large font, that oil was "The Light of the Future." John Bull, 13 June 1885, 15; Manchester Courier, 24 June 1885, 3; Illustrated London News, 1 May 1886, 470; The Times, 26 December 1885, 1; London Daily News, 22 September 1886, 3. Other companies that used Redwood as an endorsement included the Petroleum Engine Company of America (The Times, 9 June 1888, 9; The Times, 11 June 1888, 16), and the Russian Water White Petroleum Oil Company. Public Ledger and Daily Advertiser, 16 May 1884, 2. Redwood's father was frequently referenced in advertisements for Pears' Soap: "I have never come across another toilet soap which so closely realizes my ideal of perfection." The Times, 13 December 1897, 12; The Times, 3 January 1898, 10; The Times, 9 January 1899, 12.
} 
all in court." 165 That same year, the Corporation of London retained Redwood as its consulting adviser responsible for the "official testing of petroleum in the City." ${ }^{166}$ By 1896, Redwood had added to his duties in London the positions of Chemical Advisor to the Oil Trade Section of the London Chamber of Commerce, and Honorary Advisor to the Admiralty on matters of oil. ${ }^{167}$

Redwood's global perspective on oil affairs was particularly valuable. During the 1880s and 1890s, he visited several emerging oilfields in places around the world, including trips to India in 1882, Germany, Austria, France, Belgium, and Holland in 1883, Ireland in 1884, and Egypt in $1890 .{ }^{168}$ Redwood became known to Tsar Nicholas II, who frequently sought his advice on the rapidly expanding Russian petroleum industry. ${ }^{169}$ Perhaps most valuable to Redwood was his extensive field work experience in the United States which, in 1886, produced more oil than the rest of the world combined. ${ }^{170}$

Redwood worked to share his knowledge of oil with many different communities in Britain. One of the ways in which he engaged with new audiences during the $1880 \mathrm{~s}$

\footnotetext{
165 "The Water Safety Lamp," The Times, 3 June 1890, 4; "Recent Fire in the City," The Times, 30 October $1890,6$.

166 "The South-Eastern Circuit," The Times, 4 December 1890, 6.

${ }^{167}$ Redwood, 1896, ii; Automobile Club Journal, 26 February 1903, 8.

${ }^{168}$ Shortly after delivering the Cantor Lectures, in 1886, Redwood travelled to North America as part of an eight-week tour on behalf of the Petroleum Association. In 1890 and 1892, Redwood was dispatched to Egypt by the Royal Society of Arts, along with fellow scientist Sir Frederick Abel, to enquire about the possibility of carrying crude oil through the Suez Canal. "The Storage of Petroleum," Pall Mall Gazette, 11 October 1883, 7; Belfast Telegraph, 11 October 1883, 4; Public Ledger and Daily Advertiser, 11 October 1883, 3; "West of England Importers of Petroleum," Exeter and Plymouth Gazette, 29 February 1884, 8; Globe, 17 September 1886, 4; Birmingham Daily Post, 18 September 1886, 5; "Interested in Petroleum," New York Times, 10 October 1886, 7; Evening Star [Washington, D.C.], 29 November 1886, 1; "Suez Canal and Petroleum Traffic," Western Mail, 5 March 1892, 5; The Engineer, 24 June 1892, 545.

169 "Mark Twain and the Pilgrims," The Times, 26 June 1907, 3; "Mark Twain and the Savage Club," The Times, 1 July 1907, 14; "Court Circular," The Times, 22 February 1909, 13; Journal of the Royal Society of Arts, 1920, 97.

${ }^{170}$ M. Mitzakis, 1922, 394.
} 
and 1890s was through professional institutes and learned societies. In 1866, at the age of just twenty-two, Redwood was elected a Fellow of the Chemical Society (FCS), and he later became a Fellow of the Institute of Chemistry (FIC), a Fellow of the Royal Society of Edinburgh (FRSE), and Fellow of the Royal Geographical Society (FRGS). He also took up less formal positions with the British Association, the Royal Society of Chemistry, the Royal Geological Society, and the Royal Botanic Society. ${ }^{171}$ At many of these societies' meetings, Redwood delivered lectures or presentations on topics such as "The Petroleum Fields of India," the subject chosen for the Society of Chemical Industry in 1890, or "The Transport of Petroleum in Bulk," the topic selected for the Institution of Civil Engineers in $1894 .{ }^{172}$

Given the leap in the consumption of oil in Britain, it was with excellent timing that in 1896 Redwood published the most important book of his career-Petroleum: $a$ Treatise on the Geographical Distribution and Geological Occurrence of Petroleum and Natural Gas. ${ }^{173}$ Petroleum functioned as an encyclopaedia of oil, offering readers a full spectrum analysis of the resource and its physical properties, from the smallest hydrocarbon molecule to the vast global networks of drilling rigs, pipelines, and the

\footnotetext{
171 "The King of Saxony," The Times, 26 March 1890, 3; "The British Association," The Times, 29 November 1893, 10; "The Petroleum Trade," The Times, 22 September 1894, 4; "Botanical Notes," Bulletin of the Torrey Botanical Club 12, no. 5 (May 1885): 54; "Meeting of the Royal Geographical Society," Geographical Journal 3, no. 1 (January 1894): 67-68. The Chemical Society was formed in London in 1841 by Robert Warington. In 1869, Redwood's father, Theophilus, was elected Vice-President of the Society, a position he held until 1872. Boverton Redwood served as a Council Member from 1891 1892, and again from 1910-1914. "Funeral of Dr. Redwood, of Boverton," Barry Dock News, 25 March 1892, 6; T. Moore and J. Philip, The Chemical Society, 1841-1941 (London: The Chemical Society, 1947): 12-13, 221, 225.

172 "The Petroleum Fields of India," The Times, 24 April 1890, 13; New York Times, 5 July 1890, 6; "Oil in India," Pittsburgh Dispatch, 20 July 1890, 15; “To-Day," The Times, 30 January 1894, 5. In late 1894, the Institution of Civil Engineers awarded Redwood its Telford Premium prize for his research on evacuating petroleum vapors from storage tanks. "Institution of Civil Engineers," Morning Post, 7 June 1894, 3; "Proceedings of the Institution of Civil Engineers," The Times, 30 November 1894, 14.

${ }^{173}$ B. Redwood, Petroleum (London: Charles Griffin, 1896). The book was dedicated to Redwood's father, Theophilus Redwood: "In whose laboratory I received my early instruction in practical chemistry."
} 
refineries that transformed the resource into usable products. ${ }^{174}$ The book was a comprehensive reference volume, on the one hand, and a detailed historical narrative of oil, on the other, readily accessible, therefore, to both specialist and non-specialist audiences. It showcased Redwood's command of the field of petroleum science, and stands as a testament to his authority as Britain's scientific expert of the oil age.

One of Redwood's central achievements in Petroleum was the conversion of oil from an invisible and seemingly dangerous substance into one that was recognizable, familiar, and comfortable. Redwood brought the lessons that he had learned in the lecture theatre and courtroom into his book. He used images to communicate complex ideas to readers and to assist them in building an imaginative framework within which to think about oil. Visual aids such as graphs, tables, illustrations, maps, and photographs can be found throughout Petroleum. The reader opens the first volume to discover a large foldout map of the world, decorated with red dots indicating known petroleum fields; several pages later, another map located the "Petroleum Deposits of the Old World," with Britain's petroleum scarcity in full view. ${ }^{175}$ Photographs were also used to introduce British readers to the places from which their oil came and the people who helped in its production and processing. Through these images, readers could actually see how new wells were being drilled, how fountains of oil gushed from the ground, and how pipelines and oil refineries were constructed. Illustrations and diagrams of oil technologies, such as

\footnotetext{
${ }^{174}$ The 900-page work was organized into two luxuriously appointed volumes, which featured numerous foldout maps, diagrams and illustrations, a statistical appendix, and a large bibliography. Charles Griffin, a well-respected publisher of scientific and statistical works, published a second edition of Petroleum in 1906, a third edition in 1913, a three-volume fourth edition, posthumously in 1922, and a fifth edition in 1926. In the final reprinting, the number of pages swelled from the original 900 to 1353, largely the result of additions to the bibliography and statistical appendix.

${ }^{175}$ Redwood, 1896, 46.
} 
kerosene lanterns and early oil engines and boilers, showed the reader the different ways in which the resource was being consumed.

Petroleum exemplifies Redwood's skill as a gifted storyteller who helped Britons make sense of oil and its complicated impact on their lives. He acknowledged that oil was a spectral substance that was difficult to define and comprehend, and that it confounded even members of the scientific community. The nomenclature by itself was complex: "petroleum, rock oil, earth balsam, earth oil, mineral oil, bitumen, maltha, asphaltum, pissasphaltum, pisselaeum, mumia, carabe, brea, oleum Médea, St. Quirinus's oil, Seneca oil, Rangoon oil, Persian naphtha, Trinidad pitch, Barbados tar \&c., and equivalent terms in other languages," made the standardization of oil terminology a pressing issue for scientists, industrialists, regulators, and consumers. ${ }^{176}$ Furthermore, Redwood noted, oil could take on several different forms, such as invisible vapour or gas, a solid brick (bitumen) or viscous liquid. ${ }^{177}$ By recognizing the difficulty that a reader might have in making sense of oil and its many facets, Redwood connected with his audience and found common ground through education - the invisibility of oil could be overcome by knowledge, it is argued in Petroleum. With respect to public fears about sudden and spontaneous oil explosions, Redwood informed his readership that they should not work inside recently-emptied petroleum storage tanks, not the least because the "breathing of air charged with a considerable quantity of petroleum vapour quickly produces insensibility." $" 178$

\footnotetext{
${ }^{176}$ Redwood, 1896, 1. In 1945, at the third Cantor Lectures on Petroleum, Sir Frank E. Smith noted that Redwood's definitions of petroleum products still endured after fifty-nine years. F. Smith, "Chemicals from Petroleum," Journal of the Society of Arts 93 (October 1945): 565.

${ }^{177}$ Redwood, 1896, 183.

${ }^{178}$ Redwood, 1896, 518. On the fear of oil suddenly exploding, see "The Submarine Disaster," Manchester Guardian, 18 February 1905, 8.
} 
As he had done in previous forums, Redwood grounded his presentation of oil in an historical context, using sketches of the past to plot the contemporary consumption of oil on a natural and predictable trajectory. Central to Redwood's historical narrative were the "ancient records" of petroleum consumption: the Asian empires of China and Japan, where petroleum was extracted from hand-dug wells; the Middle East, where Zoroastrian "Fire Worshippers" burned petroleum in their mysterious "ancient temples;" and North America, where pre-contact Indigenous peoples raised crude petroleum from "ancient pits." ${ }^{179}$ Transitioning to Europe, Redwood traversed historical landscapes more familiar to the reader: Herodotus's encounters with oil in the Levant, a mainstay of Redwood's oil story; the writings of Greek essayist Plutarch on oil; the use of oil for science and war by Alexander the Great and Julius Caesar; and the oil discoveries made by Marco Polo in places across the world. Drawing the narrative even closer to the orbit of contemporary readers, Redwood invoked the "slime pits" recorded in Genesis, which, he argued, were likely made of bitumen. ${ }^{180}$ These narratives served to acquaint the reader with oil, while simultaneously drawing clear distinctions between the oil of the past and that of the present. Redwood's frequent invocation of the past and his thumbnail sketches of the historical uses of petroleum conveyed several messages to the readership, most notably that the ancient and the modern were bound together by petroleum, a resource that transcended time and historical periodicity.

Redwood also used notions of history and time to differentiate the old from the new. While his histories placed the ancient and modern consumer in the same story, and

\footnotetext{
179 Redwood, 1896, 1-4.

${ }^{180}$ Redwood, 1896, 2. On theories related to the slime pits of Genesis, see S. Peckham, "The Genesis of Bitumens, as Related to Chemical Geology," Proceedings of the American Philosophical Society 37, no. 157 (January 1898): 108-139.
} 
along the same narrative arc, they also suggested ideas about difference, distance, and otherness. Redwood informed his reader at length about "early" and "primitive methods" used by ancient societies to acquire oil "many centuries before the Christian era," in order to produce a sharper distinction between the primitive ancients and the "modern methods" used by "civilised races" to acquire and consume oil. ${ }^{181}$ Considerable space in the book is dedicated to the range of products made available by petroleum, such as lamp and heating oils, leather cleaner, vaseline jelly, household paints and detergents, cosmetics, dry cleaning chemicals, and preservatives for eggs, meat, fruit, and flowers. ${ }^{182}$ The ancient and modern both used petroleum, Redwood argued, but the latter did so with superior science, technology, and purpose.

Redwood linked these ancient histories of oil to the time of the reader using the vehicle of modern technology. Alongside the primitive techniques used by historical societies to acquire oil, Redwood spent dozens of pages detailing the advanced science and technology that were being marshaled by the oil industry across the world. The book is rich with hopeful notions of scientific improvement and progress, and a pervasive optimism that, with time, the use of oil could transform the world. Here Redwood deployed the vast majority of the illustrations, diagrams, and photographs that are included in the book - visuals of oil fields, drill bits, oil derricks, pipelines, storage tanks, and delivery vehicles. ${ }^{183}$ Once again travel accounts were deployed by Redwood to convey the themes of excitement, drama, and romance associated with oil. The photographs, maps, and illustrations provided important context for his narratives about

\footnotetext{
${ }^{181}$ Redwood, 1896, 3, 6, 241, 291, 323, 661.

182 Redwood, 1896, 180-227, 241-309, 661-664.

${ }^{183}$ Redwood, 1896, 3, 6, 241, 323.
} 
the global energy transition to the Age of Oil, and helped to shape an imaginative portrait of the resource in the mind of the reader.

Petroleum was an immediate success in Britain and across the English-speaking world, and praise for the work was close to unanimous. The Automobile Club Journal described Redwood's study as the "standard work on petroleum," while a review published in Petroleum World claimed the book to be "undoubtedly the most comprehensive and complete treatise on petroleum... [and] the only book in existence which gives the oil man a clear and reliable outline of the growth and present-day condition of the entire petroleum world." "184 A review in the magazine Nature described Petroleum as "so perfect an example of what a book of reference should be" that it was "modern in every sense of the word." ${ }^{185}$ In 1907, a review published in the Geographical Journal pronounced the work to be "a tribute to the great industry of the author, who is associated with all the most important petroleum undertakings in England," and concluded that Redwood had completed "the most masterly work that has been published on the subject." ${ }^{186}$ In the Journal of the Chemical Society, the English oil chemist, F. Perkin, declared that Redwood's Petroleum was "the standard English work on the subject."

Recognition for Petroleum also came from the United States, where Redwood had spent time during the drafting of the manuscript, enabling him to insert dozens of

\footnotetext{
${ }^{184}$ Automobile Club Journal (April 1903), published in J. Dodds Henry, Oil Fuel and the Empire (London: Bradbury Agnew, 1908): i.

${ }^{185}$ Nature, 24 December 1896, 169.

186 "Distribution and Economics of Petroleum," Geographical Journal (May 1907): 565-566.

${ }^{187}$ M. Perkin, "Sir Boverton Redwood, Bart.," Journal of the Chemical Society 117 (January 1920): 467. In a letter to Perkin, written in 1896, Redwood referred to Petroleum as "what my irreverent friends in the oilfields call their 'Bible." The letter is published in B. Redwood, Petroleum (London: Charles Griffin, 1896 [1922]): ix.
} 
examples and anecdotes from American sources. ${ }^{188}$ A review published by Oil News boldly asserted that Redwood's book was "the most important and complete single work on Oil ever published." 189 The United States Geological Survey expert on petroleum, Joseph D. Weeks, noted in his introduction to Production of Petroleum in 1895, that "during the year Mr. Boverton Redwood's Petroleum and Its Products has been published. This is the most important work on petroleum that has yet appeared, and we desire in this place to make a general acknowledgement of the frequent use to which the volume has been put." ${ }^{\prime 90}$ By the turn of the twentieth century, Redwood's oil monograph was a canonical text in the international literature on oil science. ${ }^{191}$

Petroleum is mentioned in numerous texts on the history of oil, but nowhere is there any mention of its photographs and illustrations, its visually appealing presentation of facts, or its imaginative storytelling techniques. Gareth Jones described the work as "a standard textbook on petroleum matters until after the First World War," while Daniel Yergin claimed Redwood's book was "the standard work for the next two decades." 192 Historians have failed to probe the nuances of Petroleum and its underlying messages about oil. The significance of the book rests not only in how many people knew about it, and how highly it was praised in the contemporary literature, but also how it came to be and the ways in which its narratives were crafted. The book was the culmination of years

\footnotetext{
${ }^{188}$ Redwood included extensive information about oil fields in Pennsylvania, New York, Virginia, Kansas, and Texas. Redwood, 1896, 48, 63, 79-80.

189 Oil News (1896), reprinted in Redwood, 1896 [1922], 364. In 1915, the El Paso Herald announced that Redwood's Petroleum had been added to the city library (8 June 1915, 9).

190 J. Weeks, Petroleum (Washington: Government Printing Office, 1896): 621; “Obituaries," Iron and Steel Institute (1897): 309.

${ }^{191}$ In his annotated bibliography of historical oil publications, E. Swanson summed up Petroleum as "one of the landmark reference books." E. Swanson, A Century of Oil and Gas in Books (New York: Appleton, 1960): 180 .

192 Jones, 1981, 97; Yergin, 1922, 123.
} 
of research, writing, speaking, and thinking about oil. In it Redwood offered his imagined world constructed from insights acquired in the hard and soft sciences - a constellation of all the peoples, places, technologies, tools, processes, and products that were required to make oil. The driving message that Petroleum offered to all readers was that Redwood had seen with his own eyes the evidence that a modern Age of Oil was on the horizon, one that held the potential to revolutionize every facet of British daily life. ${ }^{193}$

\section{Fostering Networks and Building Partnerships in the World of Oil}

In the years that followed the appearance of Petroleum: a Treatise, Redwood had a part to play in practically every event or activity related to oil in Britain. He acted as a consultant for dozens of new extraction projects undertaken by British and American oil companies, sometimes appearing in the prospectuses of two different oil company advertisements on the same page of The Times. ${ }^{194}$ In April 1909, Redwood's endorsement appeared on the prospectus of the Anglo-Persian Oil Company's first offering of shares, perhaps the most important consulting project of his career. ${ }^{195}$ His greatest impact, however, can be seen in the British literature on oil, where his name appeared in scores of books written on the subject during the period under study. Redwood wrote dozens of

\footnotetext{
${ }^{193}$ Redwood was also interested in modern art. In 1911, he purchased sketches from the artist Camille Pissaro, through the intermediary James Bolivar Manson. H. Bonnett, "The Camden Town Group in Context," Tate Modern, August 2011. Retrieved from: www.tate.org.uk/art/research-publications/camdentown-group/james-bolivar-manson-letter-to-lucien-pissarro-r1104663.

${ }^{194}$ For examples, see "British Colonial Petroleum Corporation," and "Gold Coast Oil and Bitumen Corporation," The Times, 12 December 1908, 16; "New Zealand Oilfields," and "Castellon Oil Company," The Times, 8 April 1910, 23. Redwood was frequently cited in company prospectuses as an advisor or consultant. At the shareholder meeting of the Nigeria Bitumen Corporation, Redwood delivered a speech in which he argued for "the very great superiority of petroleum over coal as a source of power in steamraising, in internal combustion engines, and in other ways." "Nigeria Bitumen Corporation," Manchester Guardian, 13 December 1908, 2.

195 “Anglo-Persian Oil Company," Manchester Guardian, 12 April 1909, 2. On Redwood's involvement with the Anglo-Persian Oil Company during this period, see Chapter 3.
} 
forewords, prefaces, and introductory notes for colleagues in the field of oil science, including J. Thomson's The Petroleum Lamp (1902), the Pall Mall Gazette's "Guide to the Oil Companies" (1910), and the E. Cunningham-Craig's Oil Finding (1912). ${ }^{196}$

Redwood also co-published several technical manuals and professional handbooks with fellow scientist J. Thomson, including the widely used Handbook on Petroleum (19011906). ${ }^{197}$ But perhaps his most widely read and distributed publication during the period was his 12-page entry on "Petroleum" in the 1911 edition of the Encyclopaedia Britannica. ${ }^{198}$

Considered one of the most comprehensive collections of its kind, the Encyclopaedia included the work of 1500 subject specialists, 320 historians, and many diplomats, theologians, scientists, and government officials. ${ }^{199}$ A feature of the publication was its dense collection of information - 40,000 articles, and 44 million words. ${ }^{200}$ According to one online repository, the 1911 edition was "arguably, the last

\footnotetext{
${ }^{196}$ J. Thomson, The Petroleum Lamp (London: Charles Griffin, 1902); Pall Mall Gazette, "Pall Mall Gazette" Guide to the Oil Companies Particulars of the Principal Oil Companies (London: Pall Mall Gazette, 1910); E. Cunningham-Craig, Oil-Finding: An Introduction to the Geological Study of Petroleum (London: Arnold, 1912). Redwood also contributed content to T. Thorpe, A Dictionary of Applied Chemistry (London: Longmans, 1893); F. Clowes, The Detection and Measurement of Inflammable Gas and Vapour in the Air (London: Crosby Lockwood, 1896); J. Henry, Baku: An Eventful History (London: Constable, 1905); J. Hicks, The Laboratory Book of Mineral Testing (London: Charles Griffin, 1906); J. Mitzakis, The Russian Oil Fields and Petroleum Industry (London: Pall Mall, 1911); H. Wyatt (ed.), Motor Transport and Empire (London: St. Clements, 1913); S. Illingworth, The Co-Operation of Science and Industry (London: Charles Griffin, 1914); C. Tinkler, The Chemistry of Petroleum and Its Substitutes: A Practical Handbook (New York: D. Appleton, 1915); A. Campbell, Petroleum Refining (London: Charles Griffin, 1918); J. Arthur Green et al., A Treatise on British Mineral Oil (London: Charles Griffin, 1919).

${ }^{197}$ B. Redwood and J. Thomson, Handbook on Petroleum for Inspectors Under the Petroleum Acts (London: Charles Griffin, 1901); B. Redwood and J. Thomson, The Petroleum Lamp: Its Choice and Use (London: Charles Griffin, 1902); B. Redwood and J. Thomson, Handbook on Petroleum (London: Charles Griffin, 1906). For a selection of Redwood's editorial publications, see The Engineer, May 1901, 576; Geographical Journal, January 1907, 565; B. Redwood, "Report on a Sample of N'Hangellite from Inhambane, Portuguese East Africa," Bulletin of the Royal Botanic Gardens (1907): 151-153; "The Supply of Petroleum," The Times, 29 July 1908, 4.

${ }^{198}$ B. Redwood, "Petroleum," Encyclopedia Britannica, Vol. 21 (Cambridge: Cambridge University Press, 1911): 321-333.

199 "The New Encyclopaedia," New York Tribune, 20 February 1911, 5; Evening Star, 22 April 1912, 13.

200 “The ‘Encyclopaedia Britannica,"” British Medical Journal 1, no. 2615 (11 February 1911): 324.
} 
general encyclopedia to offer articles in such extreme depth." ${ }^{201}$ The extended length of subject essays, some of which were ten times as long as entries in other encyclopedias, led some to view the volumes as literary works, rather than as a reference collection. The British Medical Journal heralded the publication as "an event of the first importance in the history of contemporary literature," and a "fresh survey of the world in every department of knowledge." ${ }^{202}$ Several important aspects that distinguished the 1911 edition from its predecessors, the Journal conveyed to its readers, were its compact size and light weight. "A feature of the work which should particularly commend it to the average man... is that it is readable." It was the collection's accessibility and narrative style that made it unique, and as the Guardian commented in 2012, gave it an "almost mythic quality. Its pages contain all the knowledge of a world on the brink of deep and everlasting change.. ${ }^{, 203}$ Recently, Denis Boyles undertook a project to read the full set, cover to cover, which he chronicled in Everything Explained that is Explainable (2016). ${ }^{204}$ Boyles found the $11^{\text {th }}$ edition to represent "the book of the age, the obituary of the Victorian epoch and an essential snapshot, not a preview, of a very modern era." ${ }^{205}$

Redwood's article was intended to give a top-line summary of petroleum and its associated products and technologies. The piece offers a distilled view of Redwood's vision of oil and its future, including only the most pertinent and essential aspects of the resource and aiming at both the specialist and non-specialist. Familiarizing the reader

\footnotetext{
201 Online Encyclopedia, 2018. Retrieved from: www.encyclopedia.jrank.org. 202 “The 'Encyclopaedia Britannica,"” British Medical Journal 1, no. 2615 (11 February 1911): 324. See also J. Culpepper, "1911 Encyclopedia Britannica," Reference Reviews 20, no. 3 (2006): 9.

${ }^{203}$ N. Pederson, "The Magic of Encyclopedia Britannica's 11 th Edition," Guardian, 10 April 2012. Retrieved from: www.theguardian.com/books/booksblog/2012/apr/10/encyclopedia-britannica-11thedition.

${ }^{204}$ D. Boyle, Everything Explained that is Explainable: On the Creation of the Encyclopaedia Britannica's Celebrated Eleventh Edition, 1910-1911 (New York: A. Knopf, 2016).

${ }^{205}$ Boyle, 2016, xi.
} 
with the subject of oil was a top priority. The opening sentence of the entry puts forward a definition of petroleum that is free of scientific jargon: "a term which, in its widest sense, embraces the whole of the hydrocarbons, gaseous, liquid and solid, occurring in nature. ${ }^{206}$ As he had done in his lectures and in Petroleum, Redwood began the entry with a series of historical sketches, which helped to construct a starting point to the story of oil. "Petroleum was collected for use in the most remote ages of which we have any records," he revealed, before listing a sampling of famous historical figures who had written of their encounters with oil - Herodotus, Pliny, Plutarch, Marco Polo, and Sir Walter Raleigh.

Against this historical backdrop of oil consumption, Redwood foregrounded the "Modern Development and Industrial Progress" that had characterised the use of oil in the late-nineteenth and early-twentieth centuries. The reader learned about James Young and his research on paraffin in Derbyshire in 1850, as well as the 1859 discovery of oil wells in Pennsylvania by Edwin Drake. The focus of these anecdotes was on scientific advancements and technological change, and their central message was that a rapid energy transition to oil was occurring across the world. Redwood's use of statistics, for example, highlights change over time. In 1859, American production of crude oil amounted to 1000 barrels, he reported; in 1906, production was 126.5 million barrels. ${ }^{207}$ From his vantage point in 1911, Redwood could see that the "world's supplies are now being derived from a steadily increasing number of centres," and he looked to a future in which new oil fields would be "continually opened up in other parts."208

\footnotetext{
${ }^{206}$ Redwood, 1911, 316.

${ }^{207}$ Redwood, 1911, 317.

${ }^{208}$ Redwood, 1911, 317.
} 
Although Redwood's entry on "Petroleum" is filled with optimism and technological hubris, his discussion of the origins of the world's hydrocarbons reveals the profound sense of uncertainty that surrounded oil, even in 1911. Redwood carefully parsed his words. "Consideration of the evidence," he noted after weighing the merits of several organic and inorganic theories, "leads us to the conclusion that, at least in commercially viable deposits, mineral oil has generally been formed by the decomposition of marine organisms, in some cases animal, in others vegetable, in others both, under practically normal conditions of temperature and pressure."209 The world had entered the Age of Oil, but the science behind the resource was still catching up. Similar sentiments were expressed in the New York Times, which singled out Redwood's Encyclopaedia Britannica article on "Petroleum" in a review published in April $1911 .^{210}$ "Sir Boverton Redwood, the great authority on petroleum, whose official visits to the United States made him well known to American readers, explains the latest scientific views" on oil, the paper reported to its readers. Here, too, the unfinished nature of oil science, and the "difference of opinion" that existed in the scientific community on the matter of organic and abiogenic origins, were topics of discussion.

\footnotetext{
${ }^{209}$ Redwood, 1911, 318. Redwood added that even among the "overwhelming and increasing majority" of scientists who were proponents of the organic theory of origin, there remained significant "difference of opinion." Redwood quoted the American scientist, S. F. Peckham, who observed in 1884 that, "as yet, very little is known regarding the chemical geology of petroleum." Redwood held that organic processes formed oil, but he was cautious and flexible in his views. The subject was "one of speculation," he explained, which made it impossible to conclude "that any one theory has yet found universal acceptance." S. Peckham, Petroleum and Its Products (Washington: Government Printing Office, 1884). See also S. Peckham, "The Origin of Bitumens," American Journal of Science 28, no. 164 (July-December 1884): 107; S. Peckham, "On the Nature and Origin of Petroleum," Proceedings of the American Philosophical Society 36, no. 154 (January 1897): 103-112; S. Peckham, "The Genesis of Bitumens, as Related to Chemical Geology," Proceedings of the American Philosophical Society 37, no. 157 (January 1898): 108-139. 210 “Is Petroleum Really a Mineral or a Vegetable," New York Times, 23 April 1911, 7.
} 
Like the Encyclopaedia Britannica, Redwood's mission was to acquire knowledge on his subject, and to disseminate accessible information to the consuming public about the transformative era that modern science and technology was unleashing. At the bottom of the entry on "Petroleum" Redwood included a list of oil monographs for further reading, which included authors from Britain, France, and Germany, and offered a map of his scientific connections across Europe..$^{211}$

\section{Building Networks and Shaping Minds}

Central to Redwood's educational project was a network of professional and personal friendships, which he cultivated among a variety of different communities. Beginning in the early 1900s, Redwood took on a succession of protégés and apprentices with whom he worked closely. Through fostering the careers of these students, Redwood played a key role in building the networks of power that would shape the British oil industry for decades to come. Some of his earliest protégés included adventurous scientist-explorers, individuals whom Ferrier described as "Redwood's roving geologists." These were men who travelled to places around the world collecting samples and intelligence about petroleum and its allied industries. ${ }^{212}$ Others were fellow scientists and technical experts. The most preeminent was the British chemist, Vivian Byam

\footnotetext{
${ }^{211}$ Redwood, 1911, 323. Redwood's list included the following titles: B. Redwood, Petroleum, $2^{\text {nd }}$ ed. (London: Charles Griffin, 1906); A. Beeby-Thompson, Petroleum Mining and Oil-Field Development (London: Crosby Lockwood, 1910); L. Tassart, Exploitation du Pétrole (Paris: Dunod, 1908); C. Engler and H. Hofer, Das Erdol (Leipzig: Hirzel, 1909); A. Thompson, The Oil Fields of Russia (London: Crosby Lockwood, 1908); J. Henry, Oil Fields of the Empire (London: Bradbury Agnew, 1910).

${ }^{212}$ Ferrier, 1982, 282. Redwood had rovers in Persia, Russia, Mexico, Newfoundland, Canada, and the United States, including H. May, H. G. Husk, E. H. Cunningham-Craig, and S. Lister James, who became chief geologist for British Petroleum in Persia. Ferrier, 1982, 96, 400.
} 
Lewes. ${ }^{213}$ Lewes built a successful career as a respected expert in the science of oil, rising to prominence in a manner very similar to that of Redwood, through ability and coming to public attention through lectures, and by publishing materials aimed at diverse audiences. ${ }^{214}$ Redwood's influence on Lewes's work with petroleum was profound. In 1913, Lewes delivered his own Cantor Lectures to the Royal Society of Arts, on the topic of "Liquid Fuel," some twenty-seven years after Redwood's lectures on "Petroleum and Its Products." 215 Lewes observed that the abundant "petroleum era" that he envisioned in the future would be followed by ever more challenging energy regimes. One particularly prescient forecast involved a "residues era," in which "the dregs of the coal and oil supply would be utilized... while the then existing generations would curse their forefathers for their profligate waste of the natural riches that had marked the past." 216

${ }^{213}$ Vivian Byam Lewes was born in London in 1852. He was a classmate of Redwood's at University College School, where he trained in chemistry. In the late 1880s, Lewes lectured at the Royal Naval College, and in 1888 he was made Professor. During the 1890s and 1900s, Lewes and Redwood worked on several projects together. In 1892, Lewes was elected Chief Superintending Gas Examiner to the City of London, a position that brought him into the close orbit of Redwood, who served as the City's executive petroleum consultant. The two later served on the Special Committee of the Port of London Authority for investigating the storage of petroleum. In 1896, Lewes assisted Redwood in preparing the manuscript for Petroleum: a Treatise, and the two co-published several articles together. "The Storage of Petroleum," Pall Mall Gazette, 20 August 1883, 7; "Court of Common Council," The Times, 1 April 1892, 11; "Incandescent Oil Lighting System," Engineer, 31 May 1901, 576; "Port of London and Imports of Petrol," The Times, 6 November 1912, 17; "Professor V.B. Lewes," The Times, 25 October 1915, 10; “The Passing of Five Notable Men," Illustrated London News, 30 October 1915, 6; H. Gay, "Technical Assistance in the World of London Science, 1850-1900," Notes and Records of the Royal Society of London 62, no. 1 (2008): 72.

${ }^{214}$ Lewes delivered the Cantor Lectures on "Gaseous Illuminants" and "Acetylene" in 1890 and 1898 , respectively, as well as a lecture on "The Action of Heat Upon Ethylene" to the Royal Society of London, in 1894. He wrote numerous handbooks and technical manuals, including V. Lewes, Service Chemistry: Being a Short Manual of Chemistry and its Applications in the Naval and Military Services (London: Whittingham, 1889); Inorganic Chemistry, with a Short Account of its More Important Applications (London: Whittingham, 1889); Air and Water (London: Methuen, 1892); Laboratory Note Book for Chemical Students (Westminster: A. Constable, 1900); Acetylene: A Handbook for the Student and Manufacturer (Westminster: A. Constable, 1900); Liquid and Gaseous Fuels and the Part They Play in Modern Power Production (London: Archibald Constable, 1907); Oil Fuel (London: Collins, 1913). 215 "Society of Arts," The Times, 22 January 1913, 14; "Societies and Institutions," The Times, 5 February 1913, 23.

${ }^{216}$ The Times, 5 February 1913, 23. Lewes' forecast of a "residues era" is particularly prescient when read in the context of J. Urry, Societies Beyond Oil: Oil Dregs and Social Futures (London: Zedbooks, 2013), which uses an Energy Humanities approach to reflect on the age of fracking, deep water drilling, and other unconventional sources of hydrocarbons. 
Another successful Redwood protégé was Major James Dodds Henry, a British oil expert, journalist, and travel writer who published extensively during the early twentieth century. ${ }^{217} \mathrm{He}$, like Redwood, visited many of the world's up-and-coming petroleum producing regions towards the end of the nineteenth century, including multi-year tours

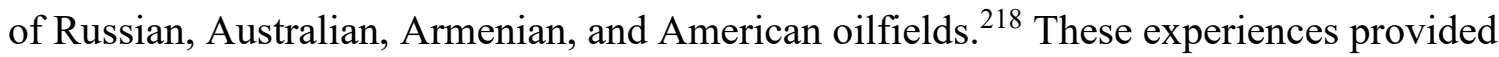
Dodds Henry with specialised knowledge and a trove of stories about petroleum and its products, making him an important voice in British oil discourses. In 1905, he published his first book, Baku: An Eventful History, which included a preface by Redwood. ${ }^{219}$ The following year, Dodds Henry founded and became editor of Petroleum World magazine, a monthly publication "devoted to the world-wide interests of the petroleum industry and its allied trades." 220

In 1912, responding to the "rapid development of the petroleum industry in various parts of the world," Redwood helped to establish Britain's first undergraduate courses on petroleum science at the University of Birmingham. ${ }^{221}$ The courses focussed in particular on petroleum mining, and were taught by Professor John Cadman, a close

${ }^{217}$ Major James Dodds Henry was born in 1864 . He trained in chemistry and became a scientific reporter on oil. In 1903, he founded the Petroleum World magazine, which later became the largest monthly oil paper in the world. Dodds Henry was an active Member of the Imperial Russian Technical Society (Baku Division), of which Redwood was an Honorary Member. J. Dodds Henry, "The Extinction of an Industry by the Tartar-Armenian Riots in the Caucuses: Great Oil-Fields and Oil-Well Fires," Illustrated London News, 16 September 1905, 2-3; J. Dodds Henry, "Oil Fuel for the British Navy," Illustrated London News, 5 March, 345.

${ }^{218}$ J. Dodds Henry, "Oil-Fields of the Empire," The Times, 15 January 1908, 4.

${ }^{219}$ In his preface, Redwood noted that Henry represented a new generation of British oil expert: "It has now fallen to another journalist, to describe the industry as it exists to-day, and to indicate the scope for far greater advancement" (vi).

${ }_{220}$ J. Dodds Henry, Oil Fuel and the Empire (London: Bradbury Agnew, 1908): i, xvii. According to an advertisement published in the front cover of the book, Petroleum World magazine was the "largest monthly oil paper in the world," and the "acknowledged representative British authority on all branches of the business" Henry, 1907, viii; Henry, 1908, xvii.

221 "The Training of Petroleum Specialists," The Times, 17 July 1912, 22; "The Oil Degree at the University of Birmingham," Gloucester Citizen, 7 January 1914, 11; "The Petroleum Industry: Training in Oil Mining," The Times, 4 March 1914, 8, 50; "University Intelligence," Manchester Guardian, 24 January 1913, 12; Science, 30 January 1914, 168; "Leading Oil Experts," Gloucester Citizen, 7 January 1914, 9. 
friend of Redwood's and a future Chairman of the British Petroleum company. With Redwood's assistance, Cadman installed different types of drilling apparatus on the campus grounds, "in order that practical demonstration of boring operations may be given, and that an opportunity may thus be afforded to students for familiarizing themselves with the appliances and methods of procedure."222

Public lecturing remained one of Redwood's favourite means of communicating ideas about oil among diverse audiences, both in Britain and internationally. During the first two decades of the twentieth century, he used his affiliations with learned societies and social clubs as conduits for sharing his vision of the global energy transition to oil. ${ }^{223}$ Redwood spoke on the new age of science at the inaugural Presidential Address delivered to the Pharmaceutical Society of Great Britain (1905), at which he was awarded the Society's Hanbury Gold Medal for "original research in the natural history and chemistry of drugs." ${ }^{224}$ At a lecture delivered to the Society of Chemical Industry in 1908, Redwood discussed the advantages of "Liquid Fuel" over solid forms like coal, and at presentations given to the British Science Guild (1910), the London Institute (1910), the Junior Institution of Engineers (1913), and the Royal Society of Arts (1913), Redwood

\footnotetext{
${ }^{222}$ After the Great War, the courses were expanded to create the country's first B.Sc. in Petroleum Mining. H. Torrens, "Cadman, John, first Baron Cadman (1877-1941)," in David Cannadine (ed.), Oxford Dictionary of National Biography (Oxford: Oxford University Press, 2004). Redwood also sponsored prizes for amateur scientists, such as producing a substitute fuel for motor spirits. "Government and the Motor Industry," Manchester Guardian, 23 March 1913, 14; "Fuel for Medical Men's Motor Cars," British Medical Journal 1 (3 January 1914): 40-42.

${ }^{223}$ For a sample of Redwood's lectures and addresses during this period, see "Inspectors of Weights and Measures," The Times, 28 April 1902, 5; "Court Circular," The Times, 17 March 1906, 10; "Motor Boats," The Times, 23 March 1906, 14; "General Notes," Journal of the Royal Society of Arts 57 (20 November 1908): 598; "The Motor Museum," The Times, 4 June 1912, 13; "Motor Transport and the Empire," The Times, 10 June 1913, 5.

224 “Correspondence," British Medical Journal 2 (16 September 1905): 677; “To-Day's Arrangements," The Times, 2 October 1905, 7.
} 
deliberated on topics such as the "Supply of Petroleum" and the "Future of Oil Fuel."225 Redwood was also an avid attendee at public lectures and was known to take part in the discussions that followed. Here, too, his vision of oil as a modern, transformative resource was displayed at a 1906 lecture delivered by Claude Johnson at the Royal Society of Arts, on the subject of "The Horseless Carriage," Redwood reminded the audience of the "marvellous rapidity" with which motor vehicles had been developed in Britain, and confided his belief that "in the present days of upheaval when people's idols were being overthrown and some of their cherished fundamental beliefs seriously shaken if not utterly uprooted, that they were privileged to observe and take advantage of the wonderful epoch-making change in locomotion."226

Public speaking events provided Redwood with important access to a wide range of listeners, including his peers in science and technology, but also those in politics, business, industry, and high society. These forums offered him a tool with which to build an expansive network of colleagues and friends in the world of oil, and a powerful pulpit for disseminating narratives about the global energy transition to oil. It is surprising, therefore, that the historical literature does not account for this component of Redwood's career, particularly when one considers how central these forums were in shaping the social and cultural landscape of oil in Britain during the period. As the archive of

\footnotetext{
${ }^{225}$ B. Redwood, "Liquid Fuel," Manchester Guardian, 23 July 1908, 8; "Supply of Petroleum," The Times, 29 July 1908, 4; Science (28 May 1909): 849-850; “Congress of Applied Chemistry," The Times, 2 June 1909, 8; Manchester Guardian, 2 June 1909, 5; British Science Guild, Natural Sources of Energy (London: the Guild, 1910); "City and Guilds of London Institute," The Times, 28 January 1910, 9; "Science and Invention," Lincoln County Leader, 25 March 1910, 7; "Oil Fuel: Sir Boverton Redwood on Its Future," The Times, 10 December 1913, 26; "Oil Fuel," Mechanical Engineer, 12 December 1913; "Address of Sir Boverton Redwood," Engineer, 19 December 1913, 663; "The Future of Oil Fuel," Journal of the Royal Society of Arts 62 (26 December 1913): 103-116; "Future of Oil Fuel," Scientific American Supplement 77 (11 April 1914). On the Hanbury Gold Medal, see Pharmaceutical Journal, 6 August 1881, 124.

${ }^{226}$ C. Johnson, “The Horseless Carriage," Journal of the Society of Arts 54 (17 November 1905): 359-376.
} 
historical British press reporting makes clear, Redwood's prognostications about oil left a deep and lasting stamp on his audiences. The Royal Society of Arts, for example, was sufficiently impressed by his lecture delivered in 1906 on the "history of motors and motor-boats from early time up to the present day" that Redwood was awarded its Silver Medal. ${ }^{227}$ The Vice-President of the American Association for the Advancement of Science, at the Association's annual meeting in Chicago 1907, stated that his address followed in the "custom" of Sir Boverton Redwood's famous oil lectures. ${ }^{228}$ Redwood's keynote lecture on "Fuel," delivered at the Seventh International Congress of Applied Chemistry in London in 1909, was "rich in matter, suggestive, splendidly illustrated and excellently presented," according to a story published in Science, while The Times reported to its readers that Redwood's talk had "dominated the proceedings of the day," in large measure because "[n]o subject of greater actual importance has come before the congress." 229

In 1908, Redwood's public speaking was memorialised in a caricature produced by the British cartoon artist, Leslie Ward, who drew under the pen name, "Spy." [Figure 2]. Ward was known for his honest and often humorous portrayal of contemporary

\footnotetext{
${ }^{227}$ The lecture was chaired by Sir John Thornycroft, a reputable shipbuilder who designed one of Britain's first steam boats, the Nautilus, and the world's first torpedo boat. He served with Redwood on the Royal Commission on Fuel and Engines in 1912. Thornycroft's son, Isaac Thomas, was close friends and racing partners with Redwood's son, Bernard. "Court Circular," The Times, 17 March 1906, 10; "Motor Boats," The Times, 23 March 1906, 14; "Society of Arts," The Times, 20 June 1906, 5; E. Carlyle, "Thornycroft, Sir John Isaac (1843-1928)," in D. Cannadine (ed.), Oxford Dictionary of National Biography (Oxford: Oxford University Press, 2004).

228 "A Plea for the Broader Education of the Chemical Engineer," Science, 17 January 1908, 81.

229 “A Fuel Famine," Evening Express, 2 June 1909, 2; “The Congress of Applied Chemistry," The Times, 2 June 1909, 8; “The Seventh International Congress of Applied Chemistry," Science 30 (17 September 1909): 377-378. The Congress was comprised of delegates representing chemical associations from around the world, many of which Redwood was directly involved with, including: the Royal Society; the Society of Chemical Industry; the Institute of Chemistry; the Chemical Society; the Pharmaceutical Society; the Society of Public Analysts; the Royal Society of Edinburgh; the Royal Society of Arts, and the London Chamber of Commerce. W. Macnab and W. Ramsay (eds.), Seventh International Congress of Applied Chemistry (London: Partridge \& Cooper, 1910).
} 
"celebrities and notorieties," and the gentleness of his critique gained him privileged access to Britain's upper classes. ${ }^{230}$ As Ward himself stated in his book, Forty Years of Spy (1915), "I have met in the course of my long professional career as a cartoonist and portrait painter...practically every person of note in the London world of the last forty years." ${ }^{231}$ Redwood's caricature was entitled "Petroleum," and was part of Ward's "Men of the Day" series. ${ }^{232}$ The caricature took the form of a tall, slender man, dressed in a white-collared shirt and tie, and wearing a frock coat and polished black shoes and spats. Redwood's signature orchid was affixed to his lapel. The scientist stood next to a large wooden table similar to the kind used in his public lectures. A Redwood Viscometer sat on the table beside to a small cup filled with a sample of oil. ${ }^{233}$ Ward's Redwood was a sophisticated and quietly authoritative figure, with an air of respectability and sympathetic intelligence. He was established, confident, fully in control of himself and his subject.

\footnotetext{
230 "Sir Leslie Ward ('Spy')," Manchester Guardian, 16 May 1922, 10; P. Kennedy, “A Very Victorian Caricature: Leslie Ward \& Vanity Fair," Illustration Chronicles, 2016. Retrieved from: www.illustrationchronicles.com/A-Very-Victorian-Caricature-Leslie-Ward-Vanity-Fair. Born in London in 1851, Leslie Ward worked under the pseudonym "Spy" for Vanity Fair magazine from 1873-1911, during which time he created 1,325 cartoons. He was knighted in 1918 and died on 15 May 1922. "A Peep at 'Spy': Mr Leslie Ward at Home," Sketch, 10 January 1894, 17; “Obituary,” Hull Daily Mail, 1 July 1922, 5; P. Mellini, "Ward, Sir Leslie (pseud. Spy), 1851-1922," in D. Cannadine (ed.), Oxford Dictionary of National Biography (Oxford: Oxford University Press, 2004).

${ }^{231}$ L. Ward, Forty Years of Spy (New York: Brentano, 1915): i. Ward imagined himself as part cartoonist, part chronicler: "I venture to prophesy that, when the history of the Victorian Era comes to be written in true perspective, the most faithful mirror and record of representative men and the spirit of their times will be sought and found in Vanity Fair." (331).

${ }^{232}$ Sir Leslie Ward, "Sir (Thomas) Boverton Redwood, $1^{\text {st }}$ Bt.," 1908. National Portrait Gallery, NPG D45425.

${ }^{233}$ According to Redwood, the viscometer was used in the "testing of the viscosity of lubricating oils...By means of this instrument the time occupied in the flow of a measured quantity of the oil through a small orifice at a given temperature is measured." B. Redwood, 1911, 322.
} 
Figure 2: Sir Thomas Boverton Redwood, standing next to his namesake viscometer

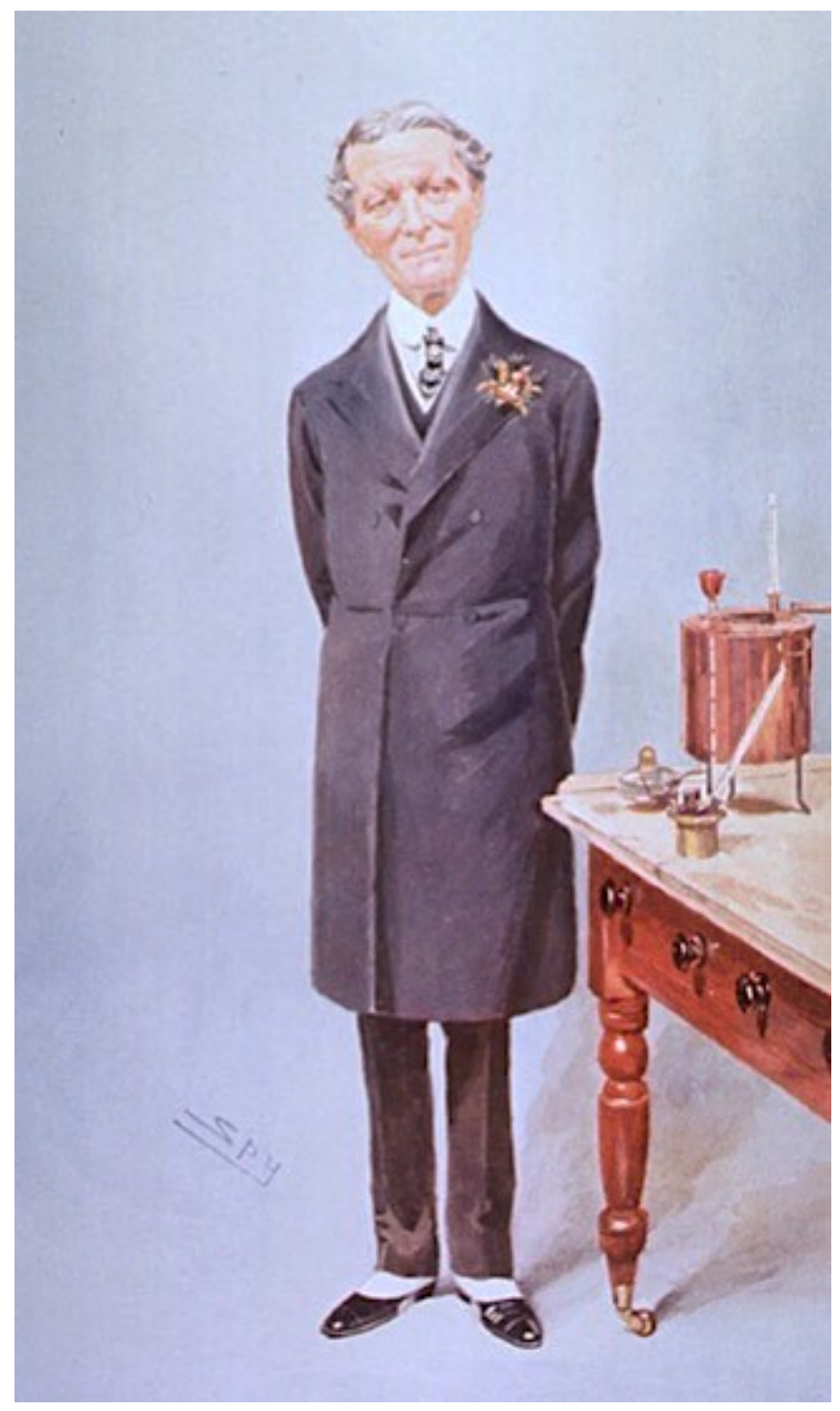

“Spy” [Leslie Ward], Vanity Fair, 24 March 1908.

Redwood's most enduring contribution to the development of early British oil science and petroculture was the founding in March 1914 of the Institution of Petroleum Technologists. The establishment of the Institution was an important milestone in the 
history of oil in Britain, demonstrating the maturation of the field of oil science and its

professionalization. The Institution was designed to advance the interests of oil

professionals in Britain and to "promote the better education of persons desirous of

becoming professional consulting petroleum technologists." ${ }^{234}$ The founding of the

Institution offers a clear indication of Redwood's leadership role within the communities

of British petroleum experts and enthusiasts. More specifically, the organization

showcased the power of Redwood's networks of friends and colleagues in the industry.

Much of the funding for the project was generated by them: Sir John T. Cargill, the

Chairman of the Burmah Oil Company; Viscount Cowdray, the politician and Mexican

oil magnate; Edward Hubert Cunningham-Craig, a discoverer of oil in Persia and the

Senior Petroleum Geologist to the Admiralty; Sir Charles Greenway, the Chairman of the

Anglo-Persian Oil Company; Professor John Cadman, future Chairman of BP, and

Vivian Lewes. ${ }^{235}$

234 “"The Empire's Oil," Manchester Courier, 21 January 1914, 10; “The Petroleum Industry,” The Times, 4 March 1914, 8; "Oil Share Market," Gloucester Citizen, 15 July 1914, 5; "Birth of Petroleum Industry," Belper News, 13 December 1935, 15.

235 "Petroleum Technologists," The Times, 12 November 1913, 23. J. T. Cargill was the son of the founder of the Burmah Oil Company, in which Redwood had served as Chairman. Lord Cowdray was a British building contractor credited with the discovery of oil in Mexico. E.H. Cunningham-Craig was one of Redwood's most successful roving geologists, and an integral part of G. B. Reynolds's 1909 discovery oil in Persia. Charles Greenway was Chairman of the Anglo-Persian Oil Company from 1917-1923. John Cadman was a petrology professor who served with Redwood on the Royal Commission on Fuel and Engines (1912). In 1923, Cadman became Chairman of the Anglo-Persian Oil Company, a position he held until his death in 1941. "Oil for the Navy," Manchester Guardian, 6 January 1918, 10; T. Corley, "Cargill, Sir John Traill, first baronet (1867-1954)," in D. Cannadine (ed.), Oxford Dictionary of National Biography (Oxford: Oxford University Press, 2004); G. Jones, "Pearson, Weetman Dickinson, first Viscount Cowdray (1856-1927)," in D. Cannadine (ed.), Oxford Dictionary of National Biography (Oxford: Oxford University Press, 2004); H. Torrens, "Craig, Edward Hubert Cunningham- (1874-1946)," in D. Cannadine (ed.), Oxford Dictionary of National Biography (Oxford: Oxford University Press, 2004); T. Corley, "Greenway, Charles, first Baron Greenway (1857-1934)," in D. Cannadine (ed.), Oxford Dictionary of National Biography (Oxford: Oxford University Press, 2004); H. Torrens, "Cadman, John, first Baron Cadman (1877-1941)," in D. Cannadine (ed.), Oxford Dictionary of National Biography (Oxford: Oxford University Press, 2004). 
The inaugural meeting of the Institute was held on 3 March 1914, in the Great Room of the London headquarters of the Royal Society of Arts. ${ }^{236}$ Redwood acted as Chair of the meeting, which took place in the same room where he had delivered the Cantor Lectures on "Petroleum and Its Products" twenty-eight years earlier. Lewes spoke of the tremendous growth of oil consumption in Britain, leading him to conclude that "at the present time no other profession offered the fascination and the prizes which were open to petroleum technologists." ${ }^{237} \mathrm{He}$ then proposed a motion to elect Redwood the Institute's first President. The motion passed and Redwood stepped forward to deliver his inaugural address. ${ }^{238}$ He spoke of the "great development of the petroleum industry," not only in Britain but around the world, and asserted the need for scientists to "accumulate trustworthy information regarding the production or winning of petroleum," and, perhaps even more importantly, to fostering "the better education of persons desirous of becoming professional consulting petroleum technologists." 239 The mission of the Institution was an extension of Redwood's campaign to promote awareness about oil through accurate and trustworthy information, and to persuade Britons to become oilminded through education.

When the First World War began in the summer of 1914, Redwood's knowledge of oil science was called upon by a range of parties. Oil was a crucial war material and the procurement and management of oil resources were essential to the British war

\footnotetext{
${ }^{236}$ Journal of the Royal Society of Arts, 3 March 1914, 495-496. It was reported at the meeting that the Institute had already received more than 70 applications for membership. "Financial Gossip," Pall Mall Gazette, 2 March 1914, 11.

237 “Training in Oil Mining," The Times, 4 March 1914, 8.

238 Presidents of the Institution of Petroleum Technologists included Sir Boverton Redwood (1914-1916); Sir John Cadman (1916-1917); Sir Charles Greenway (1917-1919); Sir Frederick Black (1919-1921). For a full membership list, see "List of the Officers," in A. Dunstan (ed.), The Petroleum Industry (London: Institute of Petroleum Technologists, 1922): iv-v.

239 “The Petroleum Industry,” The Times 4 March 1914, 50; The Engineer, 4 January 1921.
} 
effort. ${ }^{240}$ Redwood maintained his role as President of the Institute of Petroleum Technologists until 1916, after which he took up consulting positions for several government departments, including the Admiralty, the Home Office, the India Office, the Colonial Office, the Ministry of Munitions, and the Controller of Trench Warfare Research. ${ }^{241}$ Redwood was also appointed to multiple wartime committees, including with Vivian Lewes to the Alcohol Motor Fuel Committee, which was tasked with concocting chemical substitutes for petroleum. ${ }^{242}$ Toward the war's end, Redwood's health began to deteriorate, but he continued to serve his country in many capacities. Taking the year 1917 as an example, in the spring, he was appointed Director of both the Munitions Petroleum Supplies Branch and the Munitions Petroleum Research Branch; later that year, in October, he was promoted to Director of Technical Investigations for the Petroleum Executive Branch, and in December, he took up the Chairmanship of the Gas Traction Committee. ${ }^{243}$

On the evening of 7 June 1918, Redwood delivered what proved to be his last public lecture: an address entitled "The Romance of Petroleum," presented to the Royal

\footnotetext{
240 "U.S. Oil in the War," The Times, 29 May 1919, 7; Imperial Institute, Petroleum (London: John Murray, 1921): 16; E. Slade, “Oil Supplies in War,” RUSI Journal 71, no.481 (1926): 119-142; D. Peyton-Smith, Oil: A Study of War-time Policy and Administration (London: HMSO, 1971); Department for Business, Energy \& Industrial Strategy (UK), Crude Oil and Petroleum Products: Imports by Product 1920-2015 (London: HMSO, 2016). British consumption of oil totalled 2.8 million tons during 1914, while total consumption over the four years of war amounted to nearly 19 million tons.

${ }^{241}$ M. Perkins, "Sir Boverton Redwood," Journal of the Chemical Society 117 (January 1920): 467. On the uses of experts during the First World War, see J. Burk (ed.), War and the State: the Transformation of British Government, 1914-1919 (London: Allen \& Unwin, 1982).

242 “Alcohol Motor Fuel," The Times, 21 May 1914, 16.

${ }^{243}$ Flight, 15 February 1917, 164; "Petroleum for Munitions," The Times, 9 February 1917, 4; "Sir Boverton Redwood," 22 October 1917, 9; "Petroleum Production and Research," Manchester Guardian, 22 October 1917, 6; "Gas for Motor Traction," Manchester Guardian, 1 December 1917, 4; Corley, 2008. Despite these considerable commitments of time and energy, Redwood continued to publish new material, including the popular Petroleum Technologist's Pocket-Book (London: Charles Griffin, 1915), and the introductory note to C. Tinkler, The Chemistry of Petroleum and Its Substitutes: A Practical Handbook (London: Crosby Lockwood, 1915).
} 
Institution in London. ${ }^{244}$ Always the chemist, Redwood discussed at length the scientific and technical aspects of oil, including its origins, chemical composition, and methods of refinement, as well as the transportation, trade, and consumption of the resource. $\mathrm{He}$ made oil visible by employing several types of visual aids, including photographs and illustrations, and scale models of oil derricks and refineries. ${ }^{245}$ Redwood was also characteristically a storyteller that evening, working to narrate oil and its impact on the everyday lives of British consumers. He highlighted the rapid growth in the use of oil technologies, and reconstructed an ancient world "superseded by the introduction of modern methods. ${ }^{246}$ In one particularly creative interaction with the audience, Redwood attempted to represent the size and scale of the global oil industry. He invited listeners to imagine a massive cylindrical oil storage tank, in which they would pour the contents of the total amount of oil made around the world in 1917. This tank would be thirty feet high and two miles in diameter, Redwood affirmed, covering an area equivalent to "three times that of Hyde Park and Kensington Gardens together." ${ }^{247}$ Continuing with his mental map, Redwood explained that, if the contents of this "super tank" were to be discharged into standard-sized rail cars, the train made would be 28,000 miles in length, "considerably more than sufficient to encircle the earth at the equator." 248

\footnotetext{
244 "Court Circular," The Times, 7 June 1918, 9; "The Romance of Petroleum," Nature 101 (29 August 1918): 516-519. Founded in London in 1799, the Royal Institution of Great Britain was a society for "diffusing the knowledge, and facilitating the general introduction, of useful mechanical inventions and improvements; and for teaching, by courses of philosophical lectures and experiments, the application of science to the common purposes of life." F. James, Guides to the Royal Institution of Great Britain: History (London: The Institution, 2000); Royal Institution, 2018. Retrieved from: www.rigb.org/our-history.

${ }^{245}$ A. Dunstan (ed.), The Petroleum Industry (London: Institute of Petroleum Technologists, 1922): 26, 33.

${ }^{246}$ Dunstan, 1922, 23.

${ }^{247}$ Dunstan, 1922, 16.

${ }^{248}$ Dunstan, 1922, 16.
} 
On 4 June 1919, at the age of 73 , Redwood died of sudden heart failure. ${ }^{249}$ His passing marked the end of an extraordinary career in the science of oil. Expressions of grief came from many different quarters, which collectively represented the tapestry of individuals touched by Redwood's life and work. John Cargill reflected in an address to his Burmah Oil Company shareholders that Redwood's death represented a "great loss not only to our own company, but the whole petroleum world." He had occupied "a unique position in the oil world and was universally recognized as the greatest authority on all matters pertaining to petroleum." ${ }^{250}$ Greenway told his Anglo-Persian Oil Company shareholders that the company owed "its existence very largely" to Redwood, and that "in losing him we have lost a most valued and trusted friend and advisor."251

Dozens of obituaries were published in newspapers and magazines across Britain. $^{252}$ The Glamorgan Gazette, in Redwood's ancestral home in Wales, proclaimed him to be "one of the greatest men the Vale of Glamorgan can lay claim to." 253 The foreign press also published obituaries on the British oil scientist, including The Times of India and Toronto's Globe, which described Redwood as "the world's greatest authority on petroleum and petroleum products." ${ }^{254}$ The Times published one of the most lengthy

\footnotetext{
249 "Sir Boverton Redwood," Manchester Guardian, 5 June 1919, 9; "Death of Sir Boverton Redwood," The Times, 5 June 1919, 17. Redwood was buried at Hampstead Cemetery, and left an estate of $£ 163,013$ to his family, which in 2018 was equal to nearly $£ 9$ million. London Gazette, 3 June 1919, 7065; "Deaths," The Times, 7 June 1919, 1; "Deaths," The Times, 20 August 1919, 13.

250 "The Burmah Oil Company," The Times, 27 June 1919, 23; T. Corley, A History of the Burmah Oil Company, 1886-1924 (London: Heinemann, 1983).

251 “Anglo-Persian Oil Company," The Times, 9 December 1919, 23; “Anglo-Persian Oil Company," Cambria Daily Leader, 9 December 1919, 2.

${ }^{252}$ See "Sir Boverton Redwood," Manchester Guardian, 5 June 1919, 9; Commercial Motor, 10 June 1919, 334.

253 "Vale Notes," Glamorgan Gazette, 13 June 1919, 3. Obituaries in Welsh newspapers were numerous. For examples, see Llangollen Advertiser, 6 June 1919, 8; "Famous Analyst Dead," Abergavenny Chronicle, 13 June 1919, 3.

254 "Petroleum Expert Dies in London," Globe, 5 June 1919, 4; "Deaths," The Times of India, 9 June 1919, 9.
} 
and detailed obituaries. Entitled "A Great Oil Expert," the piece reviewed the major events of Redwood's career, including his involvement in court trials, his testimony to Royal Commissions and legislative bodies, the invention of the Redwood Viscometer, and his extensive tours of foreign oil fields "in almost every country." 255 Particular attention was paid to the importance of Redwood's published work, specifically Petroleum: a Treatise. The obituary also noted Redwood's persistent efforts to educate and mentor Britain's community of junior oil experts and enthusiasts, citing his work in establishing facilities for the study of oil at Birmingham University and the Institute of Petroleum Technologists - achievements that "further contributed to the spread of knowledge of mineral oil.",256

Several obituaries were published in specialist oil periodicals and the official journals of learned societies to which Redwood belonged, such as Nature; the Proceedings of the American Philosophical Society; the Journal of the Franklin Institute; the Quarterly Journal of the Geological Society; the Journal of the Royal Society of Arts; the Journal of the Institute of Petroleum Technology. ${ }^{257}$ The thread running throughout nearly every obituary was of Redwood as a public scientist and educator. The Engineer lamented that "the world has lost one of its greatest authorities - if not indeed its greatest authority - on petroleum oil." ${ }^{258}$ Another obituary published in the Journal of the Institute of Metals described Redwood as "a clear expositor of any problem, however

\footnotetext{
255 The Times, 5 June 1919, 17.

256 The Times, 5 June 1919, 17.

257 “Obituary," Journal of the Royal Society of Arts (13 July 1919): 495-496; Journal of the Institute of Petroleum Technology (July 1919); Nature (1919): 287-8; Quarterly Journal of the Geological Society 55 (1919); "Minutes," Proceedings of the American Philosophical Society 58, no.7 (1919): xiii. 258 The Times, 5 June 1919, 1; The Engineer, 6 June 1919, 566; H. Leffmann, "Review: Petroleum," Journal of the Franklin Institute 193, no. 3 (1922): 428-430.
} 
complex," and someone who had "unquestioned authority" on all matters oil. ${ }^{259}$ Perhaps Redwood's most lasting legacy, the Journal continued, was his influence on the next generation of oil scientists and scholars: "Personally he was most kindly, and took a great interest in many of the younger men who became associated with him, always lending his influence to further their interests and advancement. ${ }^{260} \mathrm{~F}$. Mollwo Perkin echoed these educational themes in an obituary published in the Journal of the Chemical Society. Redwood was someone "of great activity and extreme conscientiousness," Perkin reminisced, and a mentor who was "always willing to help the younger generation...[in] commencing their career."261

One very clear demonstration of the impact that Redwood had on the development of oil science occurred after his death, in the summer of 1920 at the Crystal Palace exhibition hall in London. The Institution of Petroleum Technologists, which Redwood had founded in 1914, held its first national congress. ${ }^{262}$ Between June and August 1920, Britain's leading petroleum experts gathered to deliver papers and to advance the field of oil science in new directions. Many of the lectures were conducted in classic Redwoodian style, their goal being to provide a "bird's-eye view of the immense territory that comes within the purview of the petroleum technologist," and to afford "to the general public a popular description of the principal facts...scientific and technical matters relating to the

\footnotetext{
259 Journal of the Institute of Metals (June 1919): 426.

${ }^{260}$ Journal of the Institute of Metals (June 1919): 426.

${ }^{261}$ M. Perkin, "Sir Boverton Redwood, Bart.," Journal of the Chemical Society 117 (January 1920): 467. Frederick Mollwo Perkin was an oil chemist and author of F. Perkin, "The Oil Resources of the Empire," Journal of the Society of Arts 62 (1914): 471-488; F. Perkin, "Oils, Their Production and Manufacture," Journal of the Royal Society of Arts 63 (1915): 837-848; J. Arthur Green, et al., A Treatise on British Mineral Oil (London: Charles Griffin, 1919).

262 The gathering took place in June and August 1920, and included notable speakers E. H. CunninghamCraig, J. S. S. Brame, and Arthur Eastlake - all junior colleagues of Redwood. In 1925, the Institute created a medal and prize in honour of Redwood, awarded to outstanding petroleum technologists. "Medal Awarded to French Scientist," Manchester Guardian, 18 March 1925, 11.
} 
production, refining, transport and uses of petroleum oil." ${ }^{263}$ The lectures were a tribute to Redwood's career as a public oil scientist: the history of oil in ancient times; the origins of oil and its formation; the extraction, refining, and transportation of oil; and the consumption of oil in a myriad of products and technologies.

The lectures were published in 1922 by A.E. Dunstan, another rising authority in the petroleum science field and part of Redwood's orbit, in a collection entitled The Petroleum Industry. The book was dedicated to Redwood's legacy, and the impact he had made on practically everyone in Britain's growing community of oil scientists and professionals. The volume opened with a dedication page containing the signatures of all the speakers who had delivered papers at the Petroleum Institute Congress of 1920. It was accompanied by the following inscription: "Many of us enjoyed the honour of his friendship; all of us respected, revered, and loved him, and we wish that this, the fruit of our collaboration, should stand as a memorial to him." Dunstan included a version of Redwood's final lecture, "The Romance of Petroleum," delivered to the Royal Institution in 1918, as the first chapter of the book, because "it was felt that the book would be incomplete unless it included the lecture. ${ }^{" 264}$ Containing the scholarship of many of his closest protégés and colleagues, the volume represented the second generation of Redwoodian oil science and was intended as a vehicle for raising public awareness about oil and for training future generations of petroleum technologists.

That same year, in 1922, the fourth edition of Redwood's Petroleum was published. The monograph, which had grown to three volumes in size, included two

\footnotetext{
${ }^{263}$ Dunstan, 1922, i.

${ }^{264}$ Dunstan, 1922, i.
} 
touching obituaries, written by Arthur Eastlake and Sir Frederick Black. ${ }^{265}$ In his preface, Eastlake mentioned Redwood's Herculean effort to complete the manuscript during the twilight of the First World War, and the assistance provided by his friends and colleagues in the industry to complete the text. ${ }^{266}$ In the final paragraph, Redwood's dedication to the Age of Oil shines through: "Sir Boverton," Eastlake stated, "was the pioneer of Petroleum Technology and had always the greatest faith that the use of petroleum would extend immensely, a faith with which he lived to see realised to a greater degree than even in his most optimistic moods he ever anticipated." 267 In the Foreword, Black reflected on the ways in which Redwood had been "in touch with every source of information on petroleum," and how Petroleum, therefore, would "always remain a monument to his very extensive expert knowledge." ${ }^{268}$ Redwood had always believed in transformative power of oil, and he had built a career around educating Britons about this fact. It was, therefore, to the satisfaction of Black and "all his many friends that after his great pioneer work [Redwood] lived into the real 'oil age."”269

Conclusion: Scientist, Storyteller, and Explainer-in-Chief

\footnotetext{
${ }^{265}$ B. Redwood, Petroleum, $4^{\text {th }}$ ed. (London: Charles Griffin, 1922). Sir Frederick Black (1869-1930) was a junior colleague of Redwood's at the Institution of Petroleum Technologists, and later served as its President (1919-1921). During the First World War, Black served as Director General of Munitions Supply. Black's daughter was the second wife of British philosopher Bertrand Russell. F. Black, "Introductory Lecture," in A. Dunstan (ed.), The Petroleum Industry (London: Institute of Petroleum Technologists, 1922); Imperial War Museum, Official History of the Ministry of Munitions, Vol. 1, Industrial Mobilizations, 1914-1915 (Luton: Andrews, 2012): 32.

${ }^{266}$ Arthur William Eastlake was a research scientist who contributed to B. Redwood, The Petroleum Technologist's Pocket-book (London: Charles Griffin, 1915), and G. Andrew, Fuel (London: Ernest Benn, 1924). The second edition of the Pocket-book, published in 1923, was retitled Redwood and Eastlake's Technologist's Pocket-book.

${ }^{267}$ A. Eastlake, "Preface," in Redwood, Petroleum: a Treatise (London: Charles Griffin, 1922): xvii.

${ }^{268}$ F. Black, "Foreword," in Redwood, Petroleum: a Treatise (London: Charles Griffin, 1922): v.

${ }^{269}$ Redwood, 1922, vi-vii.
} 
This chapter has explored the emergence of oil in Britain during the period 18851914, using Boverton Redwood as a case study, and in doing so, has sought to supply historical insight into the earliest development of scientific discourses of oil in Britain, their dissemination, and their contribution to broader petrocultures. During his long and diverse career, which began in 1869 at the Petroleum Association and ended with his death in 1919, Redwood played the role of Britain's explainer-in-chief, sharing his knowledge of oil with a multitude of different audiences. He rose to pre-eminence during the formative years of the global oil industry, a period when oil products and technologies were starting to flood into Britain. The depth of Redwood's knowledge on the subject made him an invaluable asset to politicians, oil companies, and professionals, who turned to him as a trusted source of information about oil and its future. As oil products and technologies rapidly entered British daily life during the late nineteenth and early twentieth centuries, Redwood became one of Britain's - and indeed the world's leading scientific voices on all matters concerning oil.

It is challenging to examine Redwood's life and work in the absence of his private papers. However, because of the numerous contributions that he made to the literature on oil in Britain and in other countries, and his involvement in the wider world of oil, there is still appreciable primary source material available to the scholar. As this chapter has demonstrated, Redwood left an indelible mark on British ideas about oil during his lifetime. He was a prolific writer, publishing many important canonical works, as well as contributing to the work of his colleagues in the field of petroleum science. Redwood was a public scientist and an intellectual philanthropist who expended enormous energy in pursuing the goal of improving public knowledge and awareness about oil. He belonged 
to numerous learned societies and took an active part in their direction throughout his career. Even some among the British coal industry recognized Redwood's authority on oil. ${ }^{270}$ Over his forty-year career, Redwood fostered a large and powerful network of colleagues, acquaintances, and friends. Through these imbricated networks of power, Redwood shared his vision of the global energy transition to oil.

Only a handful of scholars have taken note of Redwood, and those who have done so have primarily framed him as a scientist and political advisor, a two-dimensional figure who played important, but narrow, roles in the development of oil in Britain. This chapter has sought to enrich the portrait of Redwood that appears in the existing literature by exploring his personal and professional contributions to the development of British petrocultures. By collecting the fragments of primary source materials, the chapter worked to construct a composite image of Redwood's vision of oil, and the ways in which it changed over time. The goal has been to show not only to whom Redwood communicated his ideas, but also the manner in which he communicated them, and the information that he conveyed. In doing so, it has framed Redwood as much more than a scientist and consultant, but also a skilled communicator and storyteller, and a man who dedicated his life's work to building knowledge about oil and popularising its consumption.

Over the course of his long career, Redwood developed an imagined world of oil, one that he shared throughout Britain and the oil-consuming world. Redwood played an essential role in helping Britons from a variety of different backgrounds understand oil

\footnotetext{
${ }^{270}$ William Brace, Vice-President of the South Wales Miners' Federation, wrote in 1906 that Redwood was "the greatest known expert on this subject [of oil] in the world, and this nation can, therefore, accept the doctor's carefully-thought-out answers as reliable and conclusive." "Expert's Opinion on Oil Fuel," Weekly Mail, 5 October 1907, 4.
} 
and what it meant to their everyday lives, operating as the architect of some of the earliest British petrocultures. Redwood showed that oil, and its associated products and technologies, had become permanent fixtures across Britain and the world. While his first lectures in the 1870 s and 1880 s had looked ahead to a future potentially defined by oil, in his final days Redwood was unequivocal in asserting that that future had arrived. As Henry noted in his 1908 book, Oil Fuel and the Empire, Redwood spearheaded a shift in British discourses about oil. He enriched the public's understanding of the resource, its products, and their uses, while raising the bar on the quality and accessibility of oil scholarship. Gone were the "pre-Redwoodian days of petroleum literature."271

${ }^{271}$ J. Dodds Henry, Oil Fuel and the Empire (London: Bradbury Agnew, 1908): 30. 


\section{Chapter Two \\ Illustrating the Age of Oil: King Coal, Prince Petroleo, and the Imagination of Punch Cartoonist Leonard Raven-Hill, 1912-1933}

On 10 April 1912, the conservative, highbrow, satirical weekly British magazine, Punch, published a full-page cartoon entitled "A Second String." 272 [Figure 3]. The image was created by Leonard Raven-Hill, the deputy political cartoonist for Punch, and is a superb illustration of his creative and imaginative mind. ${ }^{273}$ The pen and ink drawing depicted three characters in a ballroom with highly polished floors, decorated walls, and fluted columns. At the centre of the image was the figure of Britannia, attired as the Greek goddess, Athena. ${ }^{274}$ Dressed in an ornately decorated, floor-length robe, with strapped sandals on her feet, and wearing a Corinthian war helmet adorned by a lion, Britannia sat on a curule, a judgement seat used by Consuls in the ancient Roman Senate from which they administered the Empire. ${ }^{275}$ On her right, in the place of honour, stands the youthful clean-cut figure of Prince Petroleo, who appears in Roman dress, wearing a

${ }^{272}$ L. Raven-Hill, “A Second String,” Punch, 10 April 1912, 363. Founded in London in 1841, Punch: or the London Charivari, was read by a middle and upper middle-class audience. The magazine satirized royalty, the clergy, and politicians, while sympathising with the working poor. As historian Frank Palmeri has written, "Punch was read in every vicarage and officers' mess, in country houses and gentlemen's clubs, in palaces and in universities." Charles Graves, has made similar observations, noting that "Punchites prided themselves on the fact that their paper was run by gentlemen who sat their horses well, who belonged to clubs and hunted foxes and would not have been out of place in any drawing room in England." C. Graves, Mr. Punch's History of Modern England, Vol. 4, 1892-1914 (London: Cassell, 1922): 35; R. Price, A History of Punch (London: Collins, 1957): 1; A. Prager, The Mahogany Tree: An Informal History of Punch (New York: Hawthorn, 1979): vii, 33. F. Palmeri, "The Cartoon: the image as critique," in S. Barber and C. Peniston-Bird (eds.), History Beyond the Text (London: Routledge, 2009): 40.

${ }^{273}$ Leonard Raven-Hill was a prolific British illustrator and cartoonist. During the late nineteenth century, he was an illustrator for popular publications such as Idler, Sketch, and the Pall Mall Magazine. From 1910-1935, he was Punch's Deputy Political Cartoonist. E. Knox, "Hill, Leonard Raven- (1867-1942)," in D. Cannadine (ed.), Oxford Dictionary of National Biography (Oxford: Oxford University Press, 2004). ${ }^{274}$ On the relationship between Britannia and Athena, see R. Matthews, "Britannia and John Bull: From Birth to Maturity," Historian 62, no. 4 (2000): 799-820; M. Warner, Monuments \& Maidens: The Allegory of the Female Form (London: Weidenfeld and Nicolson, 1985).

${ }^{275}$ Two curule benches were placed in the Senate House, one for each Consul, and they connoted legal authority, political power, and military supremacy. L. Taylor, and R. Scott, "Seating Space in the Roman Senate and the Senatores Pedarii," Transactions and Proceedings of the American Philological Association 100 (1969): 529-582. 
bright white, knee-length tunic, strapped sandals, and a diadem around his head, marked with the word 'OIL.' ${ }^{276}$ On Britannia's left stands the middle-aged, taller, bearded figure of King Coal, dressed as an Anglo-Saxon warrior in the style of Alfred the Great. ${ }^{277}$ In stark contrast to his bright and clean counterpart, the King is generously layered in coal dust. Draped across the King's strong chest and shoulders is a heavy cloak, which is fastened at his left shoulder with a brooch. Beneath this blackened outer layer, the King wears a tunic, loose trousers cross-gartered up to the knee, and heavy boots. Around his neck hangs a necklace fashioned from black lumps of coal. Attached to the King's waist, barely visible through the many layers of clothing, are the outlines of a large, circular shield and the tip of a broadsword. A black crown, billowing clouds of smoke, sits atop the King's head.

King Coal is a powerful figure, in the prime of life, proud and self-assured. “[J]auntily," he informs Britannia, "Afraid I've cut one or two of our dances.",278 Seated on her chair of judgement, Britannia appears almost unfazed by the grievous social slight. Her unsmiling face and the coolness of her reply ("Oh, don't apologise! It has given me the opportunity of making the better acquaintance of Prince Petroleo - Very nice and gushing”), exposes a moment that passes un-noticed by the overconfident King Coal.

\footnotetext{
${ }^{276}$ On diadems and their function in Roman costume, see E. Fantham, "Covering the Head at Rome: Ritual and Gender," in J. Edmondson and A. Keith (eds.), Roman Dress and the Fabrics of Roman Culture (Toronto: University of Toronto Press, 2008).

${ }^{277}$ King Coal's attire closely resembles contemporary depictions of King Alfred, particularly the beard, cross-gartered trousers, large cloak tied at the shoulder, circular shield, and broadsword. In 1899, a large bronze statue of Alfred was erected in Winchester to commemorate the millennial anniversary of his death. Alfred's clothing is nearly identical to that of Raven-Hill's King Coal character. "Statue of King Alfred," Art Journal 3 (1877): 356; F. Powell, "The Alfred Millenary of 1901," North American Review 173, no. 539 (1901): 518-532.

${ }^{278}$ The text accompanying a cartoon is known as the letterpress, which establishes the context and dialogue of the image, and provides information about the allegories and metaphors present in the cartoon.

Letterpresses are often descriptive and explanatory, but they can also contain their own subtle and implicit messages. F. Palmeri, "The Cartoon: the Image as Critique," in S. Barber and C. Peniston-Bird (eds.), History Beyond the Text (London: Routledge, 2009): 47.
} 
And, in a gesture that also appears to escape the King's notice, Britannia casually holds a small posy of flowers, which she uses nonchalantly to point towards Prince Petroleo, as if to underscore the younger man's more agreeable company. As conceited as he is selfassured, King Coal twirls his moustache, apparently deaf to the warning words uttered by Britannia: "You mustn't think you'll always be indispensable." In Prince Petroleo, Britannia had discovered a possible second string to her bow, a dancing partner who was younger, cleaner, more biddable, and refined.

"A Second String" is a historical document produced at the dawning of Britain's early-twentieth century transition from a predominantly coal-fuelled way of life to one increasingly powered by oil. The cartoon represents, in a single image, the emergence of oil as an exciting new source of fuel, heat, and power and, at the same time, the frustration and anxiety that many Britons felt about the British coal industry. The figures of Britannia, King Coal, and Prince Petroleo are inscribed with multiple layers of meaning, serving as motifs that channel the complexity of Britain's changing energy landscape into characters and narratives that were familiar to contemporary readers. "A Second String" offers an allegory of the ebb and flow of fossil fuels in Britain during this period, and the ways in which foreign oil was rapidly emerging as a rival to British coal. In this concentrated frame, Raven-Hill conveys his perception of an energy transition waiting in the wings. Britannia, representing the British energy consumer and appearing as the fulcrum of power in the cartoon, is situated between the end of an old regime and the beginning of a new - metaphorically sitting at the intersection of the Age of Coal and the Age of Oil. 
What stories and ideas about oil does "A Second String" convey? How does this cartoon fit into larger British discourses of oil and energy in transition during the early twentieth century? What do creative documents such as this tell energy historians about the past, and how they might be used to reconstruct previous experiences and interpretations related to oil? This chapter engages with such questions by critically investigating a sample of Raven-Hill's cartoons on oil during the first three decades of the twentieth century. Using his 1912 Punch cartoon as a point of departure, it explores the anthropomorphosis of energy into imaginary characters such as King Coal and Prince Petroleo, focussing on the ways in which these figures were used as rhetorical tools for interpreting the transition from coal to oil. Cartoons, in particular, are rich and densely packed sources. They offer an artist's point of view of an event or moment while, at the same time, they act as a cultural mirror, both reflecting and influencing the society in which they are produced. As communicative devices that both create and disseminate information for public consumption, cartoons can provide important clues about how certain people thought about oil, and how a wider range of people were taught or conditioned to think about the resource. ${ }^{279}$ "A Second String" therefore affords a valuable window on to the discourse on oil and energy transition in early twentieth century Britain. ${ }^{280}$ By the time "A Second String” was published in 1912, oil was already being

\footnotetext{
${ }^{279}$ C. Williams, “'Our War History in Cartoons is Unique': J. M. Staniforth, British Public Opinion, and the South African War, 1899-1902," War in History 20, no. 4 (2013): 491-525.

${ }^{280}$ The origins of the cartoon date to the earliest volumes of Punch. Prior to the $1840 \mathrm{~s}$, the word caricature was used to describe all humorous or satirical drawings. In the 1840 s, the term cartoon became associated with full-page illustrations that satirized relevant political topics or figures of the day. In the United States and Canada during the nineteenth and early twentieth centuries, these types of drawings were referred to as "satirics" or "political caricatures." M. Bryant and S. Heneage (eds.), Dictionary of British Cartoonists and Caricaturists 1730-1980 (Aldershot: Scolar, 1994): viii.
} 
used in Britain in ever growing quantities and applications. ${ }^{281}$ Britons such as Sir Thomas Boverton Redwood, Vivian Byam Lewes, and James Dodds Henry believed that they were "on the verge of an oil age" - sitting, like Britannia, on the precipice of a revolutionary shift in energy regimes. ${ }^{282}$

Oil scholars working in the field of Energy Humanities have noted, however, that oil is paradoxical, everywhere in the life of its consumers and yet far away from them. ${ }^{283}$ In the early twentieth century, oil was also an elusive substance, rarely seen and even less sensorily encountered. In Ross Barrett and Daniel Worden's edited collection, Oil Cultures, Ruth Salvaggio argued that oil has always been "curiously concealed" in our daily lives, trapped beneath the ground or hidden inside pipelines, storage containers, rolling stock, and car engines. ${ }^{284}$ Oil, she notes, has always been a "spectral substance," difficult to see and impossible to fully grasp. ${ }^{285}$ In order to overcome the spectrality of oil, these scholars argue that consumers must compensate through their imaginations. Thus, Barrett and Worden have demonstrated how oil is made comprehensible through “imaginative representations" and "creative accounts," which convert the inert black substance into something familiar, relatable, and often magical. ${ }^{286}$ This collective project of interpreting and representing oil through a constellation of invented stories, images, and symbols produces what Barrett and Worden conceive of as an "oil spectacle" - an imaginative petro-drama that plays out in the minds of everyday consumers when they

\footnotetext{
${ }^{281}$ P. Warde, Energy Consumption in England and Wales, 1560-2000 (Rome: Consiglio Nazionale delle Ricerche, 2007): 14.

${ }^{282}$ W. Antrobus, Oil (London: John Heywood, 1913): 7.

${ }^{283}$ E. Logar, Invisible Oil (Berlin: Springer-Verlag, 2011); I. Szeman and M. Whiteman, "Oil Imag(e)inaries: Critical Realism and the Oil Sands," Imaginations 3, no. 2 (2012): 46-67.

${ }^{284}$ R. Salvaggio, "Imagining Angels on the Gulf," in R. Barrett and D. Worden (eds.), Oil Culture (Minneapolis: University of Minnesota Press, 2014): 386.

${ }^{285}$ R. Salvaggio, 2014, 386.

${ }^{286}$ R. Barrett and D. Worden, 2014, xxiii.
} 
think and talk about oil. ${ }^{287}$ What is currently missing from this literature is research that explores the imaginative constructions of oil in Britain during the late nineteenth and early twentieth centuries.

"A Second String" is a vivid historical example of Barrett and Worden's "oil spectacle." Raven-Hill's anthropomorphised energy characters helped to envisage the opening scene of an epic and impossibly complex petro-drama which was to pitch Prince Petroleo against Britain's traditional energy monarch, King Coal. In demonstrating the messages conveyed by Raven-Hill's imaginary energy characters, this chapter works to elucidate one of the ways in which Britons made sense of their changing energy worlds. The goal of the chapter is to situate a selection of Raven-Hill's cartoons into the larger context of the development of British oil discourse and petroculture during the early rise of the Age of Oil.

${ }^{287}$ R. Barrett and D. Worden, 2014, xxv. 
Figure 3: "A Second String”

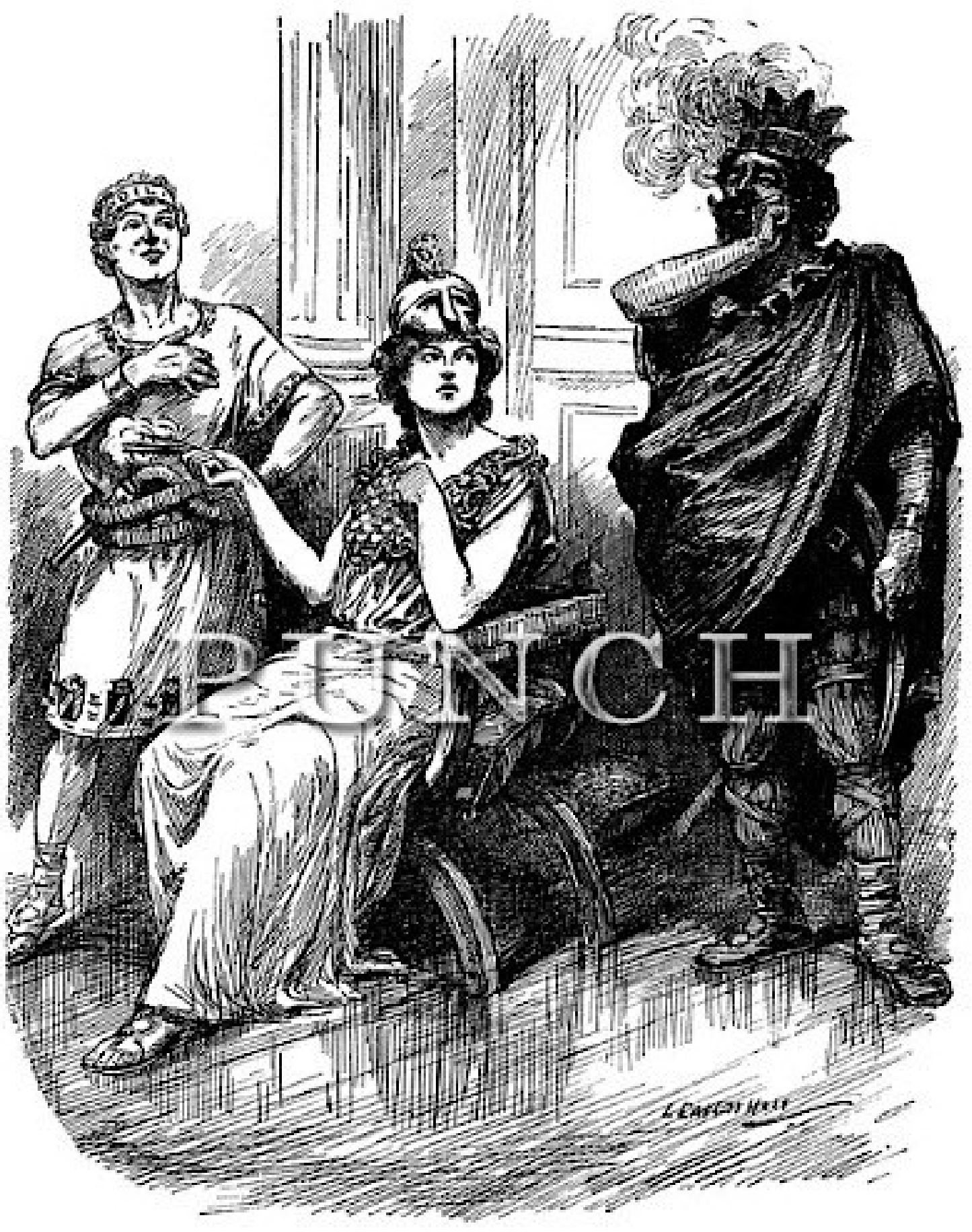

Leonard Raven-Hill, Punch, 10 April 1912. 
King Coal's Kingdom: Imagining Britain's Changing Energy Landscape

Leonard Raven-Hill was born in 1867 in Bath, and educated at the Bristol

Grammar School, the Lambeth School of Art, and the Académie Julian in Paris. ${ }^{288}$ Upon

returning to Britain in 1890, he took up a career as an illustrator, contributing to

publications such as Black \& White, Daily Chronicle, Idler, Sketch, Strand, and Pall Mall

Gazette. ${ }^{289}$ In 1895, he published his first cartoon in Punch and, in 1901, the magazine

hired him as a full-time cartoonist and caricaturist. ${ }^{290}$ According to one of his

biographers, Leonard Raven-Hill was “a short, rotund, fierce-tempered Welshman,” a

hard working and "irascible" man, who was notoriously difficult to work with. ${ }^{291}$

Cartoon historian Frank Palmeri has commented that "[p]olitical cartoons, like

satire and caricature generally, work by means of exaggeration." ${ }^{292}$ Raven-Hill’s

cartoons, however, were notable exceptions. His illustrations were superbly drawn, and

showcased his attention to detail and appreciation of subtlety and nuance. As Price has

observed, "[e]very part of a Raven Hill cartoon was there for the purpose of some effect.

As feeling rose, he rose with it. ${ }^{293} \mathrm{He}$ was an expert at portraying complex emotions and

288 "A Famous Bath Cartoonist," Bath Chronicle, 10 August 1935, 13; "Raven Hill Dead," Liverpool Echo, 31 March 1942, 5; "Death of Famous Cartoonist," Gloucestershire Echo, 31 March 1942, 4; "Obituaries," Aberdeen Press and Journal, 1 April 1942, 3.

${ }^{289}$ In 1890, Raven-Hill became Art Editor of Pick-Me-Up magazine, and in 1893, he was appointed Joint Editor of the Butterfly. In 1895, he founded the illustrated magazine The Unicorn. In 1899, he illustrated Stalky \& Co., a novel written by his close friend, Rudyard Kipling. S. Houfe, The Dictionary of British Book Illustrators and Caricaturists 1800-1914 (Suffolk: Baron, 1978): 427; Graves, 1922, 202; Bryant and Heneage, 1994, 110. Raven-Hill published a cartoon portrait of Kipling in 1935. L. Raven-Hill, "The Singer of Empire," Punch, 19 June 1935, 736.

${ }^{290}$ Houfe, 1978, 427; Graves, 1922, 202.

${ }^{291}$ Graves writes that Raven-Hill was perhaps the "hardest Punchite to get along with." He was married to another tempestuous co-worker at Punch, who was known as the "dragon of the advertising department."

Graves, 1922, 202.

${ }^{292}$ F. Palmeri, 2009, 32.

${ }^{293}$ R. Price, A History of Punch (London: Collins, 1957): 217. Raven Hill's precise style worked well with the magazine's meticulous editor, Sir Owen Seaman, who demanded that cartoons "had to meet the standards of logic." Graves, 1922, 169. 
attitudes convincingly, often in simple, uncluttered scenes featuring one or two central characters, which were realistic, relatable, and inscribed with layers of meaning. ${ }^{294}$ An intelligent critic of British daily life, Raven-Hill's “dour, biting political cartoons,” as Charles Graves has described them, earned him the post of Deputy Political Cartoonist for Punch in 1910 (a position he held for 25 years), and a seat at the magazine's brainstorming space, the Mahogany Table. ${ }^{295}$ Raven-Hill was "one of the most celebrated black-and-white artists of the period."296

Raven-Hill was fascinated by energy. ${ }^{297}$ Many of his illustrations in Punch during the 1910s featured scenes of motor-vehicle crashes, dangerously crowded city streets, and the acute differences between those who could afford oil and those who could not. ${ }^{298}$

\footnotetext{
${ }^{294}$ S. Houfe writes that Raven-Hill was "one of the most versatile of the Edwardian Punch artists," known for his precision and "delicate pencil line" (Houfe, 1978, 427). Bryant and Heneage write that Raven Hill "was a fine draughtsman, good at portraying character and making the most of a wide range of jokes." Bryant and Heneage, 1994, 111. According to Knox, Raven-Hill "excelled in vitality and energy of line, and was never so pleased as when called upon to represent a scene of violent action at the shortest possible notice." Knox, 2004.

${ }^{295}$ C. Graves, Mr. Punch's History of Modern England, Vol. 4, 1892-1914 (London: Cassell, 1922): 202. Punch magazine was produced by a small editorial board known as the "Punch Club." Editorial meetings were held in strict privacy and took place around a large mahogany table. Prior to the Second World War, only one non-member was ever allowed access to the editorial meetings - Mark Twain. The table was famously inscribed with the initials and insignia of leading members of the club, including Raven Hill. See www.ronaldsearle.blogspot.ca/2013/08/the-punch-table.html. Many members of the Punch Club, RavenHill included, were also members of the exclusive Savage Club, London's "leading bohemian gentleman's club." Sir Thomas Boverton Redwood was an active member of the Savage Club during the period. Price, 1957, 31; Savage Club website, 2018. Retrieved from: www.savageclub.com. Raven-Hill moved into the position of Deputy Political Cartoonist after the illustrator, Bernard Partridge, was promoted to Principal Cartoonist. Partridge was also known for his depictions of oil and energy transitions in Punch cartoons. B. Partridge, "Beaten but Unabashed," Punch, 11 December 1918, 389; B. Partridge, "Old King Coal," Punch, 22 July 1925, 71; B. Partridge, "The New Austerity," Punch, 20 May 1942, 419.

${ }^{296}$ M. Bryant and S. Heneage, 1994, 111.

${ }^{297}$ Raven-Hill was also interested in botany. The cartoonist was a Member of the Royal Botanical Society, along with Redwood, during the 1910s. "Botanical Notes," Bulletin of the Torrey Botanical Club 12, no. 5 (May 1885): 54; "Royal Botanic Society of London," The Times, 29 February 1912, 4.

${ }^{298}$ For examples, see L. Raven-Hill, "Brothers in Adversity," Punch, 12 June 1901, 438; L. Raven-Hill, "Too Good for Belief," Punch, 3 December 1919, 463; L. Raven-Hill, "The British Worker," Punch, 16 June 1926, 635; L. Raven-Hill, "The Guy-Hards," Punch, 3 November 1926, 479; L. Raven-Hill, "Not O.K.," Punch, 14 December 1932, 647; L. Raven-Hill, "Black Magic; or the New King Coal," Punch, 26 July $1933,87$.
} 
Several particularly striking themes used by Raven-Hill during this period addressed ideas of change, transition, and revolution in Britons' use of energy.

One of the most chaotic and uncertain moments in British industrial history, characterised by a surge in labour unrest and strike actions, occurred the year that RavenHill became deputy political cartoonist at Punch ${ }^{299}$ In 1910 , tensions boiled over in the coalfields of South Wales, where strikes and violent riots spread quickly, posing a threat to the stability of the national economy. Though ultimately unsuccessful, the Welsh miners' actions marked the start of two years of labour turbulence that, at its peak, involved nearly one million British workers. ${ }^{300}$

The decade 1910-1920 has been described as "The Great Unrest," a period in Britain's history defined by immense social, cultural, economic, political, and industrial transformation, particularly in the country's large and historic coalmining industry. ${ }^{301}$

After years of unprecedented and limitless success and high profits, the coal industry had become not only outmoded, but moribund: British miners were roughly half as

\footnotetext{
${ }^{299}$ During the period 1900-1912, there were a total of 40,890 major labour disputes in the United Kingdom, and from 1900-1914 there was a fivefold increase in strike actions. The coalmining industry was at the forefront of the Great Unrest. A. McIvor, "Industrial Relations in Britain, 1900-1939," in C. Wrigley (ed.), Companion to Early Twentieth Century Britain (London: Wiley-Blackwell, 2009): 326, 328; N. McCord and B. Purdue, British History 1815-1914 (Oxford: Oxford University Press, 2007): 487-536.

300 The most infamous South Wales revolt was known as the Tonypandy Riots. The Home Secretary, Winston Churchill, reluctantly quelled the Riots with the use of the police and British Army troops, a highly controversial move that was never forgotten in the tight-knit mining communities of South Wales. The crisis was one of many labour disputes that erupted in 1910-1912, in manufacturing, iron and steel, textiles, transportation and dock workers, railway operators, weavers, shipping, and railways. On 1 March 1912, in Alfreton, miners walked off the job, initiating the first national coal strike in British history. D. Smith, "Tonypandy 1910: Definitions of Community," Past \& Present 87 (May 1980): 158-184; L. Handy, Wages Policy in the British Coalmining Industry (Cambridge: Cambridge University Press, 1981); J. Edwards, "A New History of Wales," Wales Online (2010). Retrieved from: www.walesonline.co.uk/news/wales-news/new-history-wales-dr-louise-1889456.

${ }^{301}$ McCord and Purdue, 2007, 487. Norman McCord and Bill Purdue write that the period 1880-1914 was characterized by mass urban migration, increasing secularization, the growth of commercialism and consumerism, the rapid expansion of mass popular culture, and a widening income gap. N. McCord and B. Purdue, 2007, 487; www.visual.ons.gov.uk/the-history-of-strikes-in-britain.
} 
productive as their American and German counterparts, yet they worked more hours and for less pay. ${ }^{302}$

Many in Britain, particularly those who were geographically and socially removed from the plight of coalmining communities, imagined themselves caught in the middle of a revolution. In January 1912, The Times newspaper anxiously warned its readers that "if no improvement takes place in the mining situation, the public must be prepared for a conflict between Labour and Capital, or between employers and employed, upon a scale as has never occurred before." ${ }^{303}$ Later, in February, a Times editorial imagined that the coal strike represented "the greatest catastrophe that has threatened the country since the Spanish Armada." 304 After 37 days, and the loss of over 40 million working days, the Government (also fearing civil unrest) finally intervened and passed emergency legislation to resolve the crisis. ${ }^{305}$ Dissatisfied with the terms of the bill, the miners rejected its adoption, but their leaders, in no small part fearing for the unity of the Miners Federation, prevailed upon the membership to return to work. The strike officially ended on 6 April 1912. Four days later, Raven-Hill's “A Second String” appeared in the pages of Punch magazine. ${ }^{306}$

\footnotetext{
${ }^{302}$ R. Walters, "Capital Formation in the South Wales Coal Industry, 1840-1914," Welsh History Review 10 (1980/1981): 68-92; N. McCord and B. Purdue, 2007, 493.

303 "The Industrial Situation," The Times, 6 January 1912, 7.

304 "The Coal Strike and the Public," The Times, 26 February 1912, 9. Other Londoners were fearful of the strike and its implications. A Conservative MP reportedly argued for the institution of siege rations and martial law to defeat "socialist trade unionism," while other individuals contemplated stockpiling revolvers to fend off a potential working-class revolt. M. Kelly, "Nostalgia: $100^{\text {th }}$ Anniversary of the National Miners' Strike," Journal, 26 March 2012. Retrieved from: www.thejournal.co.uk/news/north-eastnews/nostalgia-100th-anniversary-national-miners-4413682.

${ }^{305}$ House of Commons Debate, "Coal Mines (Minimum Wage) Bill," 19 March 1912, vol. 35, cc. 1723-93; House of Commons Debate, "Coal Mines (Minimum Wage) Bill," 29 March 1912, vol. 36, c. 758; House of Lords Debate, "Coal Mines (Minimum Wage) Bill," 28 March 1912, vol. 11, cc. 729-81.

306 "A Second String" was published on 10 April 1912, five days before the Titanic sank in the North Atlantic. The coal strike had fascinating implications for the vessel, and forced the White Star Line to reduce the speed of its vessels from 23 to 20 knots to save fuel. The strike ended just days before the
} 
Placed in this historical context, the cartoon can be viewed as an artist's interpretation of the events occurring in Britain's coalmining industry during the early 1910s, and a window into the changing perceptions and attitudes regarding energy issues that precipitated the strike. The cartoon is a signature Raven-Hill creation. He captures, in the facial expressions and demeanour of the three characters, the multi-facetted ills besetting the coal industry and the problems facing the Government, while at the same time expressing Britons' growing fascination with oil. Beyond the drawing itself, RavenHill uses several other clever techniques to convey the story of the emerging rivalry of King Coal and Prince Petroleo. The phrase, "a second string to one's bow," has connotations of success and failure, transition and change: "to have two (many, etc.) strings to one's bow: to have two (etc.) alternative resources." Most vitally, it carries the meaning that "a second resource [is] available if the first should fail." ${ }^{307}$ In more subliminal ways, the title also has a romantic connotation, suggesting a replacement "beau" for Britannia. Raven-Hill's audience would have appreciated the cleverness in the homonymic play on words.

The cartoon is set in a grand Edwardian ballroom, and is premised on King Coal's grave social faux pas of cutting dances, and his failure to honour all of his entries on Britannia's dance card - an allegory for the coal strike that practically shut down the country in the spring of $1912 .{ }^{308}$ The King acknowledges the slight, but his half-hearted

\footnotetext{
Titanic's maiden voyage. Free from the restraints of fuel rations, Titanic's speed was enthusiastically, and fatally, raised back to 23 knots. L. Marshall, The Sinking of the Titanic (Philadelphia: John Winston, 1912). 307 "string, n." OED Online. January 2018. Oxford University Press. www.oed.com/view/Entry/191649?redirectedFrom=second-string (accessed 22 February 2018).

${ }^{308}$ Raven-Hill alluded to the practice of using dance cards to organize the coupling of partners at large formal balls. A dance card was typically used by women and contained the names of a pre-organized sequence of dance partners. The cards were popular among early twentieth-century British socialites. For an example, see "Dance card for the annual tea party and soiree," 16 March 1906," National Archives
} 
apology is unequal to the insult, while his body language gives off an air of arrogant selfentitlement and indispensability. Britannia appears coolly polite toward King Coal, and her languid posture conveys her assessment of his unpredictable behaviour. She acknowledges his apology, but her words to him reveal an important truth. The King's absence had afforded her the opportunity of looking elsewhere for a partner, and RavenHill captures Britannia's growing awareness of oil as a potential alternative to coal. The young, clean, and handsome Prince Petroleo strikes a proud and confident pose: chin up, chest pushed outwards, one hand on his hip, and the other at his heart. Here was Britannia's second string - newly minted and prepared to replace his rival on the dance floor. ${ }^{309}$

At first glance, it is obvious that Raven-Hill wanted his viewers to imagine Prince Petroleo in fundamentally opposite ways to King Coal. The use of shading clearly divides the image into two uneven parts: on the left are the characters of Petroleo and Britannia, bathed in light, while King Coal - unaware that he is set apart from the group - is distinguished by the artist's use of dark, heavy shading. The composition and placement of the figures underscores the notion of difference between coal and oil, while at the same time reinforcing the narrative that Britannia and Petroleo are allied. The characters are also distinguished by their different heights, physical sizes and, perhaps most noticeably, by their age. Petroleo's youth suggests that he is not a boy, but not quite a man; untested but possessed of great potential and promise. Petroleo is shorter and slighter than the King, but he also stands much closer to Britannia than his rival, nearly touching her and

(UK), 768/21; E. Holland, “Tango Teas and Tangocitis,” Edwardian Promenade, 2014. Retrieved from: www.edwardianpromenade.com/dance/tango-teas-and-tangocitis.

${ }^{309}$ According to Graves, the "strike introduced a new figure into Punch's portrait gallery; 'Prince Petroleo'... 'a 'second string' and rival of the hitherto indispensable King Coal.” Graves, 1922, 134. 
very comfortable in her presence. These elements of the cartoon convey to the viewer the message that oil was discrete from coal: something different and new, a "younger," "cleaner," "leaner," and more reliable source of energy. Thus, while Petroleo projects the qualities of attentiveness, brightness, freshness, and longevity, and seems to belong in the ballroom with Britannia, King Coal is shown to be sooty, smoky, swarthy, self-absorbed, and fickle.

A closer inspection of the characters reveals even more subtle clues about how Raven-Hill imagined coal and oil as diametrically different energy sources. Around the King's waist, concealed beneath his thick cloak, are a shield and a broadsword: weapons of war that have no place in a ballroom. Around Prince Petroleo's waist, tied like a belt, is a ribbed motor spirit hose with a pointed spout at the end. At the bottom of the Prince's tunic, barely noticeable to the viewer, is a motif of a 2-gallon portable motor spirit can, which produces a creative variation on the classical Roman meander pattern. Where King Coal is clothed in the garb and accessories of war, Prince Petroleo is identified with symbols of modern technology, domestic comfort, and vitality. ${ }^{310}$ As Raven-Hill uses King Coal to represent the deeply troubled British coal industry during the early twentieth century, he employs Prince Petroleo to represent the contemporaneous emergence of oil as an alternative energy source in Britain during the same period. Just as Petroleo offered Britannia an alternative dancing partner in "A Second String," in real life oil provided both the Government and the British consumer with a new source of energy that could be used instead of coal, such as in cooking and heating applications. Beyond

\footnotetext{
${ }^{310}$ In the 1910s and 1920s, motor spirit pumps and portable metal petroleum cans were symbolic of the rapid emergence of oil and its growing ubiquity in daily life. By 1925, BP alone operated 6,000 pumps, and circulated over two million petrol cans in Britain. British Petroleum, "Distribution of Motor Spirits," $161^{\text {st }}$ Meeting of the Board, 22 July 1925; "Advertising," $166^{\text {th }}$ Meeting of the Board, 21 January 1926.
} 
replacing the use of coal, oil also promoted entirely novel technologies and uses, such as aircraft and automobiles, some 20,000 of the latter were purchased in 1912 alone. ${ }^{311}$

\section{Prince Petroleo on the Horizon}

In the early 1910 s, even in places where the use of coal was formally considered sacrosanct, oil was beginning to acquire a foothold. In 1911, one of the largest and most reliable consumers of British coal, the Royal Navy, began to investigate transitioning from coal fuel towards oil as its primary means of motive power.$^{312}$ Less than a year later, on 9 April 1912, construction commenced on the Navy's first exclusively oilpowered battleship - just three days after the conclusion of the "Great Unrest," and the day before "A Second String” was published. ${ }^{313}$ In September, the fiery and ambitious

First Sea Lord, Sir John Fisher, wrote to First Lord of the Admiralty, Winston Churchill: “I've got enthusiastic colleagues in the oil business! They're all bitten! Internalcombustion engine rabies!"314 Thus 1912 was a crucial year for oil in Britain, and marked the starting point of what many believed would be a new and exciting "Age of Oil." As

\footnotetext{
311 A. Prest, Consumers' Expenditure in the United Kingdom, 1900-1919 (Cambridge: Cambridge University Press, 1954): 142; C. Divall, "Transport, 1900-1939," in C. Wrigley (ed.), Companion to Early Twentieth Century Britain (London: Wiley-Blackwell, 2009). The development of aviation occurred in lock step during this period, as well. In 1912, the Army and Navy held the first open competition to procure new military aircraft, and a 250-acre aerodrome was scheduled for construction near Harrow to accommodate the rapid growth of personal aircraft in Britain. United Kingdom Parliamentary Papers, United Kingdom Parliamentary Papers, "Army. Military Aeroplane Competition," 1912, vol. 51, Cd. 6286; "The Future of Aviation in England," The Times, 3 February 1912, 6.

${ }^{312}$ V. Lewes, "Liquid Fuel," Journal of the Royal Society of Arts 61 (1913): 666-673.

${ }^{313}$ Oil promised the Navy faster speeds, increased power, and greater range. Oil was also a cleaner and easier fuel to use. In 1912, the newly appointed First Lord of the Admiralty, Winston Churchill, ordered the construction of several new oil-fuelled battleships. The first of these, the Queen Elizabeth, was laid down on 9 April 1912. House of Commons Debate, "Navy Estimates, 1912-1913," 18 March 1912, vol. 35, cc. 1549-1618. W. Churchill, The World Crisis (New York: Scribner, 1923): 136; G. Jones, "The Oil-Fuel Market in Britain 1900-1914: A Lost Cause Revisited," Business History 20, no. 2 (1978): 131-152.

${ }^{314}$ Back to Coal Movement, "Minutes of Proceedings of an Address given by Captain Bernard Acworth, D.S.O., R.N. on 'The Navy's Fuel,"” 1931-1932. National Library of Wales, Monmouthshire and South Wales Coal Owners Association Records, Box 1, A4/3/5.
} 
one historian of the period has written, it was during 1912 and 1913 that "the Age of Coal first encountered head-on the Age of Oil." ${ }^{315}$ It is precisely this notion of collision and potential revolution that Raven-Hill sought to express in "A Second String."

Although Raven-Hill was one of the first to represent and make accessible the emerging rivalry between coal and oil, he was only one of many Britons during the early twentieth century whose imagination was ignited by the prospects of a new Age of Oil. During the period of study, there were a variety of efforts being undertaken to interpret oil, and to construct ways of thinking about the resource and its rapid adoption into British daily life. Like Raven-Hill, many British commentators leveraged the technique of anthropomorphosis to tell the story of oil. One of the most salient themes in the discourses and petrocultures of oil in Britain during the period was the human body. Often, oil was conceived of as "feed" or "juice" for motor vehicles and, in more abstract ways, as a powerful source of "food" for both individual consumers and British society writ large. ${ }^{316}$ At the International Congress of Applied Chemistry, held in London in June 1909, Sir Boverton Redwood warned his lecture audience that they must do whatever they could to "postpone as long as possible the fuel famine which in the absence of some other source of energy must occur in every country in course of time." ${ }^{317}$ Sir John

\footnotetext{
${ }^{315}$ M. Fletcher, "From Coal to Oil in British Shipping," Journal of Transport History 3, no. 1 (1975): 5. ${ }^{316}$ Antrobus, 1913, 7, 36, 39; L. Lockhart, "B.P. by O.K.," Naft 2, no. 6 (1926): 36. Winston Churchill once wrote that British warships "were fed by oil and could only be fed by oil." Yergin, 1992, 140. Frederick Talbot wrote in his 1914 book, The Oil Conquest of the World, that oil provided "sustenance," and a "staple article of food for mankind," raising the question of whether "the community to-day eats, drinks, and sleeps - in fact, exists - upon petroleum." Talbot elucidates the growing use of oil in foodstuffs in a lively and detailed chapter entitled "The Oil Invasion of the Table." F. Talbot, The Oil Conquest of the World (London: William Heinemann, 1914): 143, 208, 274.

317 "A Fuel Famine," Evening Express, 2 June 1909, 2; "The Congress of Applied Chemistry," The Times, 2 June 1909, 8; "The Seventh International Congress of Applied Chemistry," Science 30 (17 September 1909): 377-378. The notion of an "oil famine" was also invoked by American journalist Louis Fischer. L. Fischer, Oil Imperialism: The International Struggle for Petroleum (London: Allen \& Unwin, 1926): 12.
} 
Cadman, Chairman of the British Petroleum Company, took the metaphor of food even

further in a 1927 lecture delivered to the Royal Colonial Institute in London, in which he asked his audience to "call oil the "milk' of industry." 318 The nutritional comparison was apt, Cadman asserted, because "milk is quite a perfect human food and, like oil, is a highly organised, well balanced storage of heat and power." ${ }^{319}$

The metaphor of oil as blood was also frequently used in British debates about petroleum during the early twentieth century and, in ways similar to food, this form of creative representation often framed the liquid fuel as a life-sustaining source of caloric power, nourishment, and vitality. ${ }^{320}$ On 21 November 1918, for example, French Oil Commissioner Henri Bérenger stated at a banquet held in London for the Inter-Allied Petroleum Conference that oil represented "the blood of the earth," and that "[a]s oil had been the blood of war, so it would be the blood of the peace." ${ }^{321}$ In 1925, a series of

\footnotetext{
318 J. Cadman, "The Oil Era and the British Empire," Naft 3, no. 2 (1927): 14.

319 Cadman, 1927, 14. The metaphor of food was also common in American oil literature during the period. Writing on global oil supplies in 1926, Louis Fischer claimed that it was "quite as hazardous to estimate the underground oil reserves of a given patch of oleous territory as it is to guess the quantity of gin a child in swaddling clothes will swallow by the time it is grey and rheumatic." L. Fisher, Oil Imperialism: The International Struggle for Petroleum (London: Allen \& Unwin, 1926): 10.

${ }^{320}$ The linkage between coal and blood had a well-established tradition in British energy discourses dating to the mid-nineteenth century: in 1865, Stanley Jevons conceived of coal as "the very lifeblood of the country." S. Jevons, The Coal Question (London: Macmillan, 1865): xi; in 1913, William Antrobus wrote that coal was "the life blood of a nation." Antrobus, 1913, 83; in 1931, Bernard Acworth wrote that coal was "the life-blood of English Sea Power." B. Acworth, "Oil," Naval Review (1931): 142. The linkage between oil and blood was common in American energy discourses during this period. A 1920 article published in Cosmopolitan described oil that "gets in your blood," and that turned people "stark mad - oil mad." J. Hunt, "Millionaires Made While You Wait," Cosmopolitan 68, no. 2 (1920): 139-140. An advertisement for the Columbia Motor Company, published in the same issue of the magazine, asserted that "any vigorous, red-blooded man will delight in the Columbia Six. It is built for him because it is built like him." Columbia Motors Company, "Columbia Six," Cosmopolitan 68, no.3 (1920): 115. Upton Sinclair's 1927 novel, Oil!, characterised oil as a "black and cruel demon... an evil Power which roams the earth, crippling the bodies of men and women, and luring the nations to destruction by visions of unearthed wealth and the opportunity to enslave and exploit labor.” U. Sinclair, Oil! (London: T. Werner Laurie, 1927): 527.

${ }^{321}$ D. Peyton-Smith, Oil: A Study of War-Time Policy and Administration (London: HMSO, 1971). The banquet was hosted by Lord Curzon at Lancaster House, London. Other Allied leaders also expressed ideas about oil using the metaphor of blood during this period. In 1917, Georges Clemenceau confided to Woodrow Wilson that "Oil is as necessary as blood in the battles of tomorrow." "The Day," The Times, 22 November 1918, 6 .
} 
illustrated newspaper advertisements for British Petroleum described the company's network of Persian oil pipelines as a "vein of steel" that carried "rich crude" over vast distances to British consumers, while a British travel author, writing in 1927, imagined the Persian pipeline to be "the main artery through which flows the liquid stream on which the very life of the Company depends. ${ }^{״ 22}$ In the early 1930s, British commentators on the transition to oil continued to draw upon the bodily narratives and metaphors that were much in vogue in the 1920s. Oil was frequently conceived as an essential, life-sustaining substance that had permeated the British body politic and become an integral part of the everyday. Often, the imaginary rivalry between coal and oil was employed as a narrative framework for explaining the continued "rise" of oil and the perceived "downfall" of coal. As Cadman remarked in 1931, on the competition between the two sources of energy in Britain, "coal kept on at a jog-trot pace, whilst petroleum was running." ${ } 323$

Perhaps the most compelling stories used to explain the rise of oil were those which were based upon duelling monarchs and their quest for global domination archetypes with which Britons were closely familiar. The transformation of different energy sources into anthropomorphic characters took on many forms, but the underlying story was nearly always the same: the downfall of a traditional source of power, King Coal, and the rise of an aggressive and capable new challenger, oil. While King Coal's character was generally represented as a human figure, the rendering of oil in character

\footnotetext{
${ }^{322}$ British Petroleum, "The Persian Series," Illustrated London News, 25 April-15 August 1925; J. Williamson, In a Persian Oil Field: A Study in Scientific and Industrial Development (London: Ernest Benn, 1927): 89. The correlation between oil pipelines and the arteries of human hearts was common in oil discourses of other countries. See Interprovincial Pipe Line Company, "Artery for Oil," 16mm film, 25:00 minutes. 1951.

${ }^{323}$ J. Cadman, "Problems of Coal and Oil," Naft 7, no. 1 (1931): 11-13.
} 
form varied from place to place. The British oil journalist, Frederick Talbot, described the early twentieth century as a new "oildom," in which "wealth was imperative." ${ }^{24}$ The French oil critic, Francis Delaisi, wrote in 1920 that the world had been taken over by an "aristocracy of producers," who had worked towards "dethroning coal" and instituting a new "Oil Empire." 325 The American oil journalist, Louis Fischer, feared in 1926 that the world had been taken over by an international cabal of "petrol barons," "gas monarchs," and "Oil Kings," who each possessed the ability to "exercise tremendous political power" and to put "irresistible pressure on governments." ${ }^{\text {"26 }}$ As Fischer boldly asserted in his book, Oil Imperialism, "King Coal has been dethroned...Now oil is having its day. We are living in the Oil Age, and Oil Imperialism is in the saddle." ${ }^{327}$ The American oil baron and founder of Standard Oil, John D. Rockefeller, was often referred to as "King John D.”; Sir Henri Deterding, founder of Shell Transport and Trading Company, acquired the nicknames the "British Napoleon," the "Oil World's Napoleon," and the "Most Powerful Man in the World," all titles which are suggestive of conquests, empires, and emperors. ${ }^{328}$

\footnotetext{
${ }^{324}$ F. Talbot, The Oil Conquest of the World (London: Heineman, 1914): 300.

${ }^{325}$ F. Delaisi, Le Pétrole [Oil: Its Influence on Politics] (London: The Labour Publishing Company, 1920 [1922]): 19. Delaisi also described oil companies as an "oligarchy of profiteers" (31).

${ }^{326}$ L. Fischer, Oil Imperialism: The International Struggle for Petroleum (London: Allen \& Unwin, 1926): 13-14, 245. Anthropomorphic energy characters were common in American oil literature during the period. In Oklahoma in 1913, an oil refinery operator was known as the "Prince of Petroleum. B. Wells, "Prince of Petroleum Opens Tulsa Refinery," Oilpro.com, January 2016. In 1921, an article published in Popular Mechanics Magazine featured a photograph of an American agricultural farm under the headline: "King Cotton abdicates and is succeeded by Prince Petroleum." Popular Mechanics Magazine 1, no. 35 (January 1921): 28. For additional examples of anthropomorphosis, see H. McKay, Oil: The Monarch of Motion (New York: Markets Publishing, 1919); "King Petrol,” New Statesman, 21 January 1922, 11; O. Reinholt, Oildom, Its Treasures and Tragedies (Philadelphia: David McKay, 1924).

${ }^{327}$ Fisher, 1926, 245.

${ }^{328}$ D. Ludwell, We Fight for Oil (London: Alfred Knopf, 1928); P. Tramerye, La Lutte Mondiale pour le Pétrole [The World-Struggle for Oil] (London: George Allen \& Unwin, 1921 [1927]): 67; G. Roberts, The Most Powerful Man in the World: The Life of Sir Henri Deterding (New York: Covici \& Friede, 1938).
} 
In British coal mining regions, the overthrowing of King Coal's regime was interpreted with markedly less enthusiasm. As historian Michael Thomas has written with respect to the Welsh coal mining industry, "[o]nce there was a whole region epitomized by a single word - coal. Virtually the entire population worked, either directly or in a support function, to produce and feed this raw material into the gaping maw of urban development and the burgeoning industries upon which modern society was built." ${ }^{329}$ The consumption of oil in Britain rose steadily during the first several years of the decade, often at the expense of coal. ${ }^{330}$ Millions of tons of oil products and billions of gallons of motor spirit were consumed annually, over ninety per cent of which was imported from abroad. ${ }^{331}$

This flood of oil into Britain was in stark contrast to the fortunes of the acutely troubled coal industry, which experienced during the same period some of the most difficult years in its history. ${ }^{332}$ One of the most challenging was 1926, the year of the General Strike. Raven-Hill captured some of the sense of desperation of the coal industry in a Punch cartoon published in April 1926, entitled "Waiting for a Reprieve." ${ }^{333}$ The

\footnotetext{
${ }^{329}$ M. Thomas, The Death of an Industry: South Wales Mining and its Decline - The Local Story in a Global Context (Singapore: Colben Systems, 2004): iii.

${ }^{330}$ Between 1929 and 1933, consumption of coal in Britain decreased by 15 per cent. From 1930 to 1935, the number of coal mines fell from 2,091 to 1,779, while the number of men employed decreased from 910,000 to 753,000. Department of Energy and Climate Change (UK), Historical Coal Data: Coal Production, Availability and Consumption 1853-2014 (London: Her Majesty's Stationary Office, 2015). ${ }^{331}$ R. Ferrier, The History of the British Petroleum Company, Vol. 1 (Cambridge: Cambridge University Press, 1982): 683. British imports of oil rose by more than 500 per cent between 1913 and 1931. Total oil imports for the period 1930-1933 amounted to $£ 123$ million. From 1930-1935, more than twenty-one million tonnes of motor spirits were imported into Britain. I. Thomas, Coal in the New Era (London: Putnam, 1934): 136; Department for Business, Energy \& Industrial Strategy (UK), Crude Oil and Petroleum Products: Imports by Product 1920-2015 (London: Her Majesty's Stationary Office, 2016); Department for Business, Energy \& Industrial Strategy (UK), Crude Oil and Petroleum: Production, Imports and Exports 1890 to 2015 (London: Her Majesty's Stationary Office, 2016).

${ }^{332}$ B. Supple, The History of the British Coal Industry, Vol. 4, 1913-1946: The Political Economy of Decline (Oxford: Clarendon, 1988).

${ }^{333}$ L. Raven-Hill, "Waiting for a Reprieve," Punch, 28 April 1926, 451.
} 
scene took place in a jail cell, in which a dejected King Coal sat cross-legged on a stool, staring apathetically at the wall in front of him, dressed in a royal cloak, a crown emblazoned with his name upon his head, and wearing a necklace made from lumps of coal. An hour glass labelled "subsidy" neared its end, and a gallows and noose could be seen through the cell window. According to the largest local daily in Wales, Cardiff's Western Mail newspaper, the widespread use of oil had been "a grave national blunder," which had turned Britain's coal industry into a "pathetic disaster" engaged in a "desperate fight for life." 334 The economic situation was so severe in Britain's coalmining communities during the early 1930 s that the editors of the industry's national trade magazine, the Colliery Guardian, questioned whether the country could ever "emerge from the imbroglio intact." ${ }^{335}$ Confronted by an existential crisis of unprecedented magnitude, the British coal mining industry began to explore ways to promote the use of coal and to bring the resource back to life. ${ }^{336}$

One of the most promising means of resuscitating the coal industry during the early 1930s involved, paradoxically, the use of chemical treatments to convert coal into

\footnotetext{
334 Western Mail, 1 April 1931, 6. David Davies, president of the Ocean Coal Company, asserted that 1930 was "one of the most disastrous on record," while the following year, he believed, would be remembered as a "grievous disappointment." D. Davies, "Christmas Message," Ocean and National Magazine 3, no. 12 (1930): 1; D. Davies, "Our Chairman's Xmas Message," Ocean and National Magazine 4, no. 12 (1931): 383. The editors of the Colliery Guardian journal concluded that 1930 was a "cynosure," and that 1931 was "another of those black pages in the history of the British coal mining industry." "The Coal Trade in 1930," Colliery Guardian, 2 January 1931, 45; "The Coal Trade in 1931," Colliery Guardian, 1 January 1932, 24.

${ }^{335}$ Colliery Guardian, 2 January 1931, 47. An editorial published in the Naval Review in November 1932 remarked that "Old King Coal may once have been a merry old soul; one hopes that he will be again; but at present he is a crashing old bore." "Here and There," The Naval Review 20, no. 4 (November 1932): 669. In 1934, the British coal expert, Harold Watkins, asked rhetorically: "The old monarch [King Coal] may again 'call for his pipe and call for his bowl,' but will he ever again feel cheerful enough to 'call for his fiddlers three'?" H. Watkins, Coal and Men: an Economic Social Study of the British and American Coalfields (London: Allen \& Unwin, 1934): 65.

336 This included publicity and advertising campaigns, public demonstrations, festivals, and trade show exhibitions, which highlighted new coal burning technologies, as well as new fuel variants such as pulverized coal, colloidal fuel, and coal gas. Coal Utilisation Council, Aims and Policies (London: The Council, 1933).
} 
oil. ${ }^{337}$ Since the mid-1920s, British scientists had been experimenting with ways to produce oil from coal, but it was not until the early 1930s that the British Government and the coalmining industry began to take seriously the large-scale production of hydrogenated - or liquefied - coal. ${ }^{338}$ The process was highly inefficient and even more expensive than oil refining, but Britain had a surplus of both untapped coal resources and unemployed miners. And, in the eyes of many proponents of coal, money expended on imported oil would be better spent at home. The Scottish shipping magnate, Sir John Latta, argued that the production of oil from coal would alleviate "British Bondage to Alien Oil," while another author pointed to the fact that hydrogenated coal could offer "a means of recovering our freedom from foreign control and of killing unemployment." 339 The Manchester Guardian was cautiously optimistic that hydrogenated oil from British coal would resolve many of the industry's problems, while alleviating the frictions that had existed with the consumer for decades: "We cannot look to see Old King Coal again seated in lonely grandeur on a tyrant's throne. But if he is prepared to govern through his ministers he is likely to enjoy a long and prosperous reign as a constitutional monarch.”340

\footnotetext{
${ }^{337}$ Experiments in finding new ways to produce home oil had been around for some time but had produced few practical results. In the mid-1920s, the Government-funded Fuel Research Board spent millions of pounds of taxpayer money investigating the possibility "of using potatoes, mangolds, or Jerusalem artichokes for the production of motor spirit." Other chemical processes involved high- and lowtemperature carbonization of coal, as well as pulverization. Fuel Research Board, Fuel for Motor Transport: Third Memorandum (London: Department of Industrial and Scientific Research, 1925): iii. ${ }^{338}$ E. Slade, "Oil Supplies in War," RUSI Journal 71, no. 481 (1926): 119-142; House of Commons Debate, "Economic Situation," 26 July 1933, vol. 280, cc. 2621-2718.

339 J. Latta, "British Bondage to Alien Oil," Morning Post, 25 October 1933; B. Acworth, "The Navy's Fuel," Naval Review 21, no. 3 (1933): 508.

340 "Old King Coal," Manchester Guardian, 13 June 1932, 8. In other communities in Britain, especially in the coalmining regions, support for King Coal remained strong for some time in Manchester in 1933, a King Coal Day was held "for the propagation of the various methods of coal utilisation, with a view to increasing the sales of coal." Miners' Federation of Great Britain, "Proposed 'King Coal' Day, in 1933," Annual Volume of Proceedings for the Year 1933 (London: Co-operative Printing Society, 1934): 4.
} 
In ways similar to the discourse surrounding the emergence of oil in the early 1910s, the dream of supplying Britons' appetite for oil from locally produced coal sparked a wellspring of creative activity in the early 1930s. Like traditional crude oil extracted from deep below the ground, this new type of hybridized, synthetic fuel was difficult to comprehend: it was not quite coal, not quite oil, and it was rarely seen or sensorily encountered by consumers. British commentators debated vigorously about the nature and characteristics of synthetic oil and questioned what its use meant to Britain and the British coal industry. ${ }^{341}$ Many proponents of coal viewed its conversion into oil as a waste of public money and natural resources, and as a betrayal of the traditional ways that Britons lived and worked for generations. Thus, the Western Mail frequently framed its coverage of oil during this period with headlines such as "Coal v. Oil Fight" and "Oil's March on Coal." ${ }^{342}$ In one particularly evocative editorial entitled "Coal's Battle Against Oil Fuel," the author delivered a "call to arms" for the South Wales coal mining community, claiming it "was time to fight" for coal - "Protect your homes and your families from this insidious oil aggression, which...portends the eventual downfall of Great Britain." 343

Many of the same techniques used to interpret and disseminate ideas about oil in the 1910s and 1920s were employed in British discourses of oil from coal during the early 1930s. Anthropomorphosis and metaphors related to the body remained favourite tools for thinking and talking about fossil fuels, as did stories of rivalry and jealousy, usurpation and dethronement between imaginary energy characters. A notable difference

\footnotetext{
${ }^{341}$ J. Jones, "The Present Position of the British Coal Trade," Journal of the Royal Statistical Society 93, no. 1 (1930): 1-63; K. Gordon, "Coal Products and National Defence," RUSI Journal 77 (1932): 547-558.

342 Western Mail, 3 July 1931, 11; Western Mail, 16 March 1932, 12.

${ }^{343}$ Western Mail, 23 March 1932, 12.
} 
was that, by the 1930s, in Britain's struggling coalmining regions, foreign oil was as a marauding invader that threatened to usurp King Coal and destroy his kingdom. Captain Bernard Acworth, R.N., a vocal critic of British oil policy during the interwar years, imagined in 1930 that his country was under attack from an "oily octopus," whose “tentacles” were methodically dismantling Britain's traditional industries and ways of

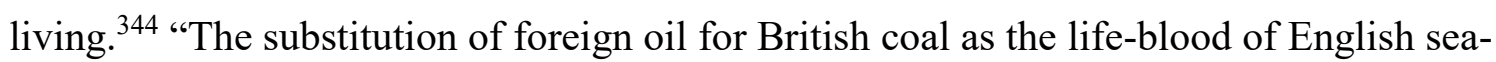
power, and progressively of industrial enterprise," Acworth wrote, "had disfigured British society at home and sapped its power abroad." 345 At a Trafalgar Day Dinner in October 1933, the Bishop of Llandaff described oil as the "hated rival" to coal, "smoothtongued, suave, gushing, alien and oily.",346

Yet, in places and interests closer to London, where petroleum products could be found everywhere and in everything, and which were far removed from coalmining communities, there were entirely different attitudes toward oil. ${ }^{347}$ Oil was here imagined as a powerful, magical, almost supernatural resource that had replaced coal as Britain's new energy lifeblood. ${ }^{348}$ To many such observers, synthetic oil derived from coal seemed

\footnotetext{
${ }^{344}$ B. Acworth, The Navies of Today and Tomorrow (London: Eyre and Spottiswoode, 1930): 127. On Acworth and other anti-oil voices, see I. Wereley, "Discourse of Dissent: Bernard Acworth, the British Anti-Oil Movement, and the Royal Navy's Use of Fuels, 1927-1937." MA Thesis. Carleton University, 2012.

${ }^{345}$ Acworth, 1930, 123.

346 Western Mail, 28 October 1933, 2.

${ }^{347}$ In 1929, a theatrical production called "Old King Coal" was put on at the Academy Theatre in London. According to one reviewer, the play offered Londoners a "faithful representation of life remote from their own." Another reviewer in the Manchester Guardian felt that the play had given actors "a chance to drive at reality with the pick and shovel," and to illuminate "a dark corner of industry with the glimmer of the safety lamp and not with a dazzle of limelight." "The Theatres," The Times, 15 May 1930, 14; "Old King Coal," Manchester Guardian, 21 May 1930, 6; "This Week’s Theatres," Observer, 25 May 1930, 15; "Old King Coal," 1930. Cadbury Research Library, MS38/4391. Another theatrical production with a similar plot, entitled "The Face of Coal," was put on in London in 1933. "Old King Coal," 1933. Cadbury Research Library, MS38/3540.

${ }^{348}$ J. Brame, "Power Fuel for the Services," RUSI Journal 76, no. 501 (1931): 64-81; J. Cadman, "The British Fuel Problem - Oil," Naft 8, no. 1 (1932): 11-14.
} 
to offer some consolation to the country's ailing coal industry. At the same time, however, the development of the technology signalled a critical - and revealing moment in the transition to oil. Oil and coal were no longer competing. Instead, coal itself had become a means to fuel the rise of oil, with each converted tonne signalling another step closer to the end of the Age of Coal. In the summer of 1933, twenty-one years after publishing “A Second String," Leonard Raven-Hill once again turned to his pen and the pages of Punch magazine to give his interpretation of a crucial moment in the British transition from coal to oil.

\section{Synthetic Fuels and the Corruption of King Coal's Body}

"Black Magic; or the New King Coal" appeared in Punch magazine on 26 July 1933. ${ }^{349}$ [Figure 4]. The cartoon offers a "second act" to the imaginative petro-drama that Raven-Hill had envisioned two decades earlier in "A Second String." The cartoon centres on the by now familiar King Coal, who is drawn with heavy, black shading. The King sits on a throne that seemed made of laboratory parts, perhaps those from a coal hydrogenation plant. On top of the King's head is a crown labelled "COAL," which has a peak like a traditional working man's cloth cap and spews black smoke. The character's face is dark and mysterious, and without the thick beard and moustache seen in "A Second String." The King's overall expression is resolute and confident, but his eyes appear almost strangely unfocussed and a faintly maniacal grin lingers at the upturned corners of his mouth.

${ }^{349}$ L. Raven-Hill, “Black Magic; or the New King Coal,” Punch, 26 July 1933, 87. 
King Coal's body is configured in interesting ways. Unlike "A Second String," the character's dress is simple, revealing few clues or messages. A jet-black tunic or robe conceals his shoulders, torso, and lower body, leaving only his left leg exposed and resting on a petrol drum. Around his waist, tied like a belt and reminiscent of Prince Petroleo's hose belt, are three strips of lightly shaded fabric labelled "CHEMICAL INDUSTRIES PLAN." His arms are fashioned as oil pipes, which include a flanged pipe connection as shoulders, ball and tap joints as elbows, and pointed pouring nozzles as hands, which echo the nozzle appearing on Prince Petroleo's belt. Coming out of the nozzles are streams of liquid that emerge like blood from King Coal's body, filling a collection of lightly shaded containers labelled "PETROL" and "OIL," which take up the foreground of the cartoon. Of note are two examples of the familiar rectangular, 2-gallon motor spirit cans that appeared on Prince Petroleo's tunic. In the bottom right hand corner, resting upside down, as if to be discarded, is a coal scuttle.

"Black Magic" takes up the energy narratives that Raven-Hill had introduced in his Second String cartoon, notably the struggle between King Coal and his rival, Oil. The cartoon includes several visual cues that link the document to others in Raven-Hill's corpus, including the use of anthropomorphic characters, simple compositions, and highly dramatic line work. ${ }^{350}$ More specifically, King Coal's smoke-billowing crown, and the motor spirit hoses, pouring nozzles, and 2-gallon oilcans in the foreground create a direct link to "A Second String." These familiar indicators immediately establish the cartoon as a sequel to the "King Coal versus Prince Petroleo" drama that Raven-Hill had

\footnotetext{
${ }^{350}$ For examples, see R. Raven-Hill, “The Joys of Motoring,” Punch, 27 February 1901, 168; R. RavenHill, "Excelsior!" Punch, 13 July 1910, 21; L. Raven-Hill, "The German Menace," Punch, 2 August 1922, 99; L. Raven-Hill, “Afghanistan Repudiates Western Ideals," Punch, 23 January 1929, 87.
} 
begun over two decades earlier, updated to reflect the changing scientific and political advancements that were occurring in the production of oil from coal in Britain. Yet, by subtitling his cartoon "the New King Coal," Raven-Hill asserts that this version of the character is radically different from the King in "A Second String." He has remade himself through hydrogenation and lives to fight another day. But he has also been conquered by Oil; his body and blood are corrupted.

In "Black Magic," Raven-Hill invoked several stories and images from his previous work, including the familiar themes of rivalry, confrontation, and controversy that saturated "A Second String." But he also conveyed new messages about oil in ways that reflected the discursive context of the early 1930s. The cartoon is a reflection of the culture in which it was produced. In particular, the document alluded to the bodily metaphors and rhetorical techniques that were common features in British energy discourses of the 1920s and 1930s. Like other commentators of the period, Raven-Hill portrayed oil as an essential, life-sustaining corporeal fluid that closely resembled blood, and which seems to "course" through King Coal's body and "gush" out of his arms. The cartoon suggested that oil had become as necessary to King Coal's survival and existence as many believed it was for the individual consumer and British society at large.

Synthetic oil from coal was presented here as a magical elixir that held the power to grant King Coal fresh life and vitality, albeit with an entirely different demeanour and spirit. ${ }^{351}$

\footnotetext{
351 The elixir refers to the trial tests conducted by Cunard of a new fuel mixture composed of oil and pulverized coal dust. This narrative of synthetic oil from coal leading to a regeneration or revitalization can be seen in other cartoons published during the period. In the summer of 1932, a cartoon entitled "A Remedy?" was published in the South Wales Echo. The cartoon depicted a very old man sitting in a bath chair labelled King Coal. The character wore a simple, loose-fitting suit-jacket, and his legs and feet were covered in thick blankets; he wore a basic crown. Looking over the aged and feeble King's shoulder was a female character named Dame Wales, dressed in traditional Welsh costume, who delivered into the King's hand a small bottle labeled "Cunard Oil + Coal Fuel." South Wales Echo, 12 June 1932, 8.
} 
Figure 4: "Black Magic; Or, the New King Coal"

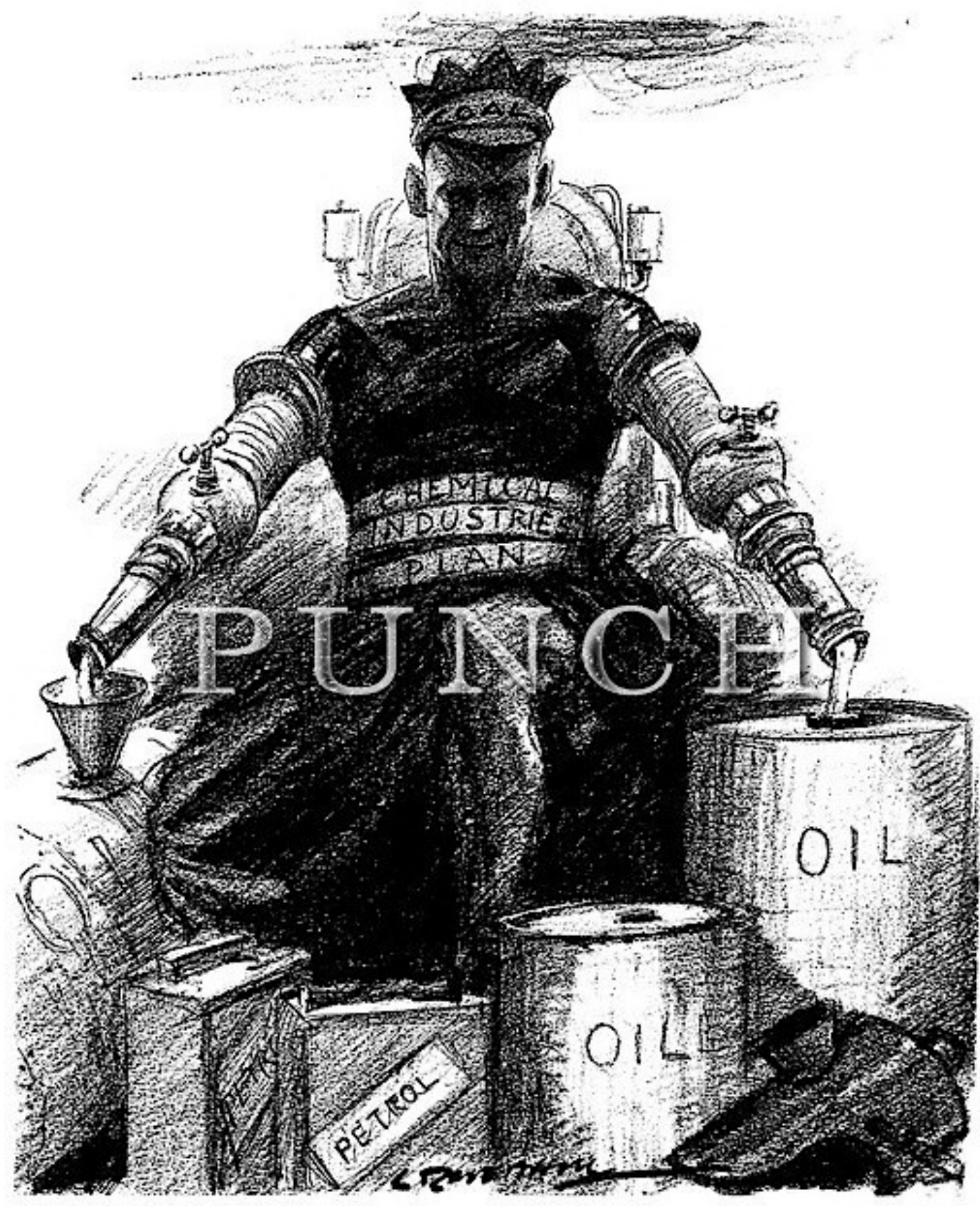

Leonard Raven-Hill, Punch, 26 July 1933. 


\section{Conclusion: King Coal's Kingdom Relinquished}

The excitement about the possibilities afforded by oil, on the one hand, and the frustration and anxiety that many Britons felt about the British coal industry, on the other, have been the focus of this chapter. The work of British cartoon artist Leonard RavenHill has been used as a vehicle for reconstructing the imaginative debates about Britain's energy future that characterised the period 1912-1933. Two political cartoons published in Punch magazine were analysed as case studies: “A Second String” (1912) and "Black Magic; or the New King Coal" (1933). Using these cartoons as a points of departure, the chapter explored the anthropomorphosis of energy into the imaginary characters of King Coal and Prince Petroleo, and sought to reveal the ways in which these figures were used as rhetorical tools for interpreting the transition from coal to oil. Employing Barrett and Worden's concept of an "oil spectacle" as a frame of analysis, this chapter highlighted the ways in which Raven-Hill inscribed King Coal and Prince Petroleo with multiple layers of meaning, and how he employed them as motifs that channelled the cultural dimensions of oil. As imaginative oil spectacles, the cartoons functioned as signposts in the making of British petroculture during the early twentieth century.

From 1912 to 1933, the consumption of coal in Britain fell by nearly twenty per cent, while over the same period, the consumption of oil products rose by more than four hundred per cent. ${ }^{352}$ Raven-Hill represented this shift as a spectacular petro-drama between the forces of Coal and of Oil. The central message that "Black Magic" delivered to its audience was that the shift from coal to oil in Britain was complete, and that the

\footnotetext{
352 Department for Business, Energy \& Industrial Strategy (UK), Crude Oil and Petroleum: Production, Imports and Exports 1890 to 2015 (London: HMSO, 2016); Department of Energy and Climate Change (UK), Historical Coal Data: Coal Production, Availability and Consumption 1853-2014 (London: HMSO, 2015).
} 
overthrow of King Coal that Raven-Hill portended in "A Second String" had come to pass. While in 1912 he characterised Prince Petroleo as a youthful and inexperienced challenger on the horizon, by 1933 the character of oil had evolved into something far more powerful, something that had changed the body and mind of King Coal forever. The advent of synthetic fuels only delayed the inevitable transition to oil that Raven-Hill imagined himself living through. For better or for worse, Britain was fully committed to the Age of Oil. Britannia and Petroleo had become intimate dancing partners. 


\section{Chapter Three \\ Building the Age of Oil: The Anglo-Persian Oil Company and the Promotion of the Llandarcy Refinery During the Early 1920s}

This chapter examines the early history of one of Britain's largest oil companies, the Anglo-Persian Oil Company (APOC), during the period $1909-1925 .{ }^{353}$ Using the company's first British oil refinery as a case study - the Llandarcy Refinery, completed in Wales in 1921 - the chapter traces the ways in which APOC communicated information about oil and oil architecture to targeted British audiences. Specifically, it reconstructs APOC's publicity activities related to the Llandarcy Refinery in order to map the different communities with whom this imaginary was shared, and to shed light on the company's vision of oil and Britain's future. As film historian Mona Damluji has noted, oil infrastructure such as derricks, refineries, and pipelines have complicated and varied meanings, representing simultaneously "a set of discourses, choices, images, and practices."354 Taking Damluji's conceptualization of oil architecture as a point of departure, the chapter demonstrates how APOC's promotional activities related to the Llandarcy Refinery portrayed the facility as an edificial symbol of the modern age of oil. Completed in the spring of 1921, the Llandarcy Refinery was defined by superlatives. It was the first facility of its kind in Britain, and it remained the largest in

\footnotetext{
${ }^{353}$ The Anglo-Persian Oil Company (APOC) was formed in 1909 to exploit the oilfields that were discovered in south-western Persia by the British financier, William Knox D'Arcy. During the period of this study, APOC distributed oil in several countries, including Great Britain (British Petroleum/BP); Scotland (Scottish Oils); France (Société Générale des Huiles de Pétrole); Belgium (Société Anonyme L'Alliance); Denmark (Det. Forenede Olie Kompagnie), and Norway (Norsk Braendselolje). For analyses of APOC's commercial activities in European markets outside of Britain see, for example: E. LeighBennett, An Adventure in Oil (London: Shell-Mex \& BP, 1931); Anglo-Iranian Oil Company, The AngloIranian Oil Company and Iran (London: The Company, 1951).

${ }^{354}$ M. Damluji, "The Oil City in Focus: the Cinematic Spaces of Abadan in the Anglo-Iranian Oil Company's Persian Story," Comparative Studies of South Asia, Africa and the Middle East 33, no.1 (2013): 87.
} 
the country for the following three decades. ${ }^{355}$ From this outpost in rural Wales, APOC transformed Persian crude oil into a myriad of products for British consumers, including the fuels, benzene, butane, diesel, kerosene, and propane; agricultural products such as distilled feedstocks and petrochemicals; the industrial chemicals, ammonia, bauxite, and sulphur; and household products, such as paints, dyes, greases, and waxes. ${ }^{356}$ But the refinery specialised in one product in particular, motor spirits, and during the period under study in this chapter the facility supplied up to one third of the total British market with motor spirits. ${ }^{357}$ The completion of the Llandarcy Refinery represented a watershed moment in the history of oil in Britain, providing for one of the first times a supply of refined oil products that were produced domestically. Fully aware that the facility represented more than the sum of its parts, APOC went to great lengths to draw attention to the project. Using a variety of different promotional activities, including special events, private tours, and the publication of newspaper advertisements and souvenir booklets, the company disseminated information about Llandarcy, oil architecture, and the modern science and technology that was required in the making of refined oil products. These promotional activities produced an archive of images, stories, and ideas about oil, which contributed to the development of British petroculture.

\footnotetext{
${ }^{355}$ R. Ferrier, History of The British Petroleum Company, Vol. 1, The Developing Years, 1901-1932 (Cambridge: Cambridge University Press, 1982): 88; D. Yergin, The Prize: The Epic Quest for Oil, Money, and Power (New York: Simon, 1992): 130-131. In addition to the Abadan and Llandarcy refineries, APOC operated two Scottish shale oil refineries at Grangemouth and Uphall, and an experimental petrochemical research station at Sunbury, England. Outside of the United Kingdom, APOC and its subsidiary companies operated refineries in Courchelettes and Lavéra (France), Alwand (Iraq), Melbourne (Australia), and Buenos Aires (Argentina). "Notes," Naft 9, no. 4 (July 1933): 1; British Petroleum, Our Industry: an Introduction to the Petroleum Industry for the Use of Members of the Staff (London: the Company, 1947): 407.

${ }^{356}$ British Petroleum, BP Oil: Llandarcy Refinery (London: the Company, 1993): 2.

${ }^{357}$ Anglo-Iranian Oil Company, Llandarcy Refinery South Wales (London: the Company, 1935): 6.
} 
The literature on the history of oil in Britain pays little attention to the Llandarcy Refinery. Several business histories have been written about APOC and its development over the twentieth century, including studies by J. R. L. Anderson, D. J. Payton-Smith, R. W. Ferrier, and J. A. Bamberg, yet these scholars spend little time assessing the Llandarcy Refinery and draw no attention to APOC's promotional activities during the period. In Anderson's East of Suez (1969), just two paragraphs are dedicated to Llandarcy, in which the author outlines the process by which South Wales was chosen as a building site, and how the company settled on naming the facility in the late 1910s. ${ }^{358}$ Anderson noted the facility coming online in 1922 (despite the fact that refined products were being produced in 1921), before picking up his narrative in 1939, entirely passing over Llandarcy's early history. ${ }^{359}$ In Payton-Smith's official history of oil and the Second World War, the Llandarcy Refinery is situated at the centre of British efforts to develop new oil products during the conflict, and applauded for its role in providing safe harbour to dozens of British oil scientists from across the country. ${ }^{360}$ There is not, however, any discussion of the refinery during the period of this study.

In the official History of the British Petroleum Company, Ferrier states that Llandarcy was an "essential part of [APOC's] strategy in the United Kingdom."361 Despite the weight of this claim, there are just eight references to the Llandarcy Refinery in the book. ${ }^{362}$ The author notes that the facility was "called, imaginatively, Llandarcy,"

\footnotetext{
358 J. Anderson, East of Suez: a Study of Britain's Greatest Trading Enterprises (London: Hodder and Stoughton, 1969): 262.

359 Anderson, 1969, 262.

${ }^{360}$ D. Payton-Smith, Oil: a Study of War-Time Policy and Administration (London: Her Majesty's Stationary Office, 1971):

${ }^{361}$ Ferrier, 1982, 483.

${ }^{362}$ Ferrier, 1982, 330. Ferrier provided details of the building costs associated with Llandarcy and their impact on APOC's annual budget.
} 
yet he provides no further analysis of the name or its meaning. ${ }^{363}$ Several sentences are dedicated to the refinery's contribution to new oil research during the early 1920 s, and there is a smattering of data related to the import and export of oil products from the port of Swansea. Nowhere in the text is there a reference to the refinery's model village. Ferrier uses very little primary source material in his discussion of the Llandarcy Refinery, citing just one BP document concerning early contractual negotiations for the facility. ${ }^{364}$ Bamburg's History of the British Petroleum Company provides some detail concerning the refinery and model village, but only with respect to its use as a bunker for petroleum scientists during the Second World War. ${ }^{365}$ There are no other significant discussions of Llandarcy in Bamburg's text.

A handful of authors have provided short synopses of Llandarcy's early history, including John Bailey and Emyr Gough's sketch in Skewen \& District: A History, and Ian Barney's book on the closure of the refinery in 1998. There are also a few short articles about the refinery in Welsh-language journals, with titles such as "Famous Industrial Institutions." ${ }^{366}$ But the most substantial body of work on the refinery comes from amateur historians and former residents of Llandarcy's model village, whose rich accounts of daily life at the facility afford historians valuable, if anecdotal, evidence. V.

\footnotetext{
${ }^{363}$ Ferrier, 1982, 453.

${ }^{364}$ Ferrier, 1982, 750. Ferrier cites ARC 79/91/9, and a series of articles on the contemporary development of bauxite and hypochlorite treatments, including A. O’Brien, "National Oil Refineries Ltd., Skewen, South Wales, during 1923," Journal of the Institute of Petroleum Technologists, 1924, vol. 10, and F. Remfry, "Bauxite as a Refining Agent for Petroleum Distillates," Journal of the Society of Chemical Industry 43, no. 24 (13 June 1924).

365 J. Bamberg, The History of the British Petroleum Company, Vol. 2, The Anglo-Iranian Years, 19281954 (Cambridge: Cambridge University Press, 1994): 195, 202, 211.

366 J. Bailey and E. Gough, Skewen \& District: A History (Neath: The Authors, 1998); I. Barney, "The Economic and Social Consequences of the Closure of BP Llandarcy," Contemporary Wales 13 (2000); I. Barney, An Economic and Social Assessment of the Closure of BP Llandarcy (Swansea: University of Swansea Press, 2000). For Welsh articles on the history of the Llandarcy Refinery, see "Sefydliadau Diwydiannol Enwog [Famous Industrial Institutions]," Y Gwyddonydd 1, no. 2 (1963): 95, and "Llandarcy," Y Gwyddonydd 14, nos. 3/4 (September 1976): 137.
} 
L. Barnes's detailed memoir, A History of Llandarcy, 1921-1971; Sheila Jones's selfpublished autobiography, Spanning the Years, and Vivian J. Griffiths's impressive history of the facility, Llandarcy Remembered, are valuable examples of the living memory of the facility. ${ }^{367}$ T. E. Stradling, a former employee, has written two selfpublished books, The National Oil Refineries, Ltd., Llandarcy, and BP Memories, both of which contain personal reflections, as well as numerous photographs of Llandarcy refinery and workers' model villages from the period $1940-1990{ }^{368}$ While these works make an important contribution to the overall history of the Llandarcy Refinery, they contain few stories pre-dating the Second World War. ${ }^{369}$

In stark contrast to the paucity of research on the Llandarcy Refinery, there is a critical mass of scholarship on the history of APOC's first and largest oil refinery, the Abadan Refinery, located in southwest Persia and completed in $1912 .{ }^{370}$ Several oil historians have featured APOC's Abadan Refinery in their research, but curiously neglect to comment on the Llandarcy Refinery. Marian Kent's Oil and Empire, Geoffrey Jones's

\footnotetext{
${ }^{367}$ V. Barnes, A History of Llandarcy, 1921-1971 (London: British Petroleum, 1972); S. Jones, Spanning the Years (Self-published memoir and photographic collection, c. 2004). BP Archives, ARC 144124/West Glamorgan Archives, D/D Z 338/43; V. Griffiths, Llandarcy Remembered (Neath: Bryngold, 2007). Griffiths worked at Llandarcy from 1954-1973. In August 2015, he produced a DVD of photographs depicting life at Llandarcy. V. Griffiths, Llandarcy to Coed Darcy: a Look Back and a Glimpse of the Future. DVD, 56:00 minutes, August 2015. ARC 252004.

${ }^{668}$ T. Stradling, The National Oil Refineries, Ltd. Llandarcy (Swansea: The Author, 2005); T. Stradling, BP Memories (Swansea: the Author, 2008). Stradling's began working at the Llandarcy Refinery in 1943.

${ }^{369}$ To the best knowledge of the author, the titles by Stradling, Griffiths, and Barnes exist only at the British Petroleum Archives, the Neath Antiquarian Society Archives, and the West Glamorgan Archives. ${ }^{370}$ See N. Kemp, Abadan (London: Allan Wingate, 1953); S. Hemlsey Longrigg, Oil in the Middle East (London: Oxford, 1954); L. Elwell-Sutton, Persian Oil (London: Lawrence \& Wishart, 1955); H. Mielche, Lands of Aladdin (London: William Hodge, 1955); W. Mineau, The Go Devils (London: Cassell, 1958), and J. Anderson, East of Suez (London: Hodder and Stoughton, 1969). For studies of the Abadan Refinery in languages other than English, see M. Fateh, Panjah Sal Naft-e Iran (Tehran: Sherkat-e Sahami-e Chehr, 1956); Institut d'études et de recherches sociales, "Abadan: Morphologie et function du tissu urbain," Revue Géographique de lèEst 4, no.4 (1964): 337-385; F. Rohani, Tarikh-e Melli Shodan-e San'at-e Naft-e Iran (Tehran: Jibi, 1973); F. Sa'adat, Pajouheshi dar Masa'el-e Nafti-e Iran (An Investigation into Iran's Petroleum Issues) (Tehran: Amir Kabir, 1976), and I. Zoghi, Masael-e Siasi-Eqtesadi-e Naft-e Iran (Tehran: Pazhang, 1991).
} 
The State and the Emergence of the British Oil Industry, Daniel Yergin's The Prize, and Timothy Winegard's The First Oil War are noteworthy examples of studies that mention Abadan, but which have no references to Britain's first and, for some time largest, oil refinery. ${ }^{371}$ In a similar vein, APOC's successor company, British Petroleum (BP), has supported the publication of illustrated books, such as Barry Ritchie's Portrait in Oil, which gives life to the history of the Abadan Refinery through photographs, paintings, illustrations, and historical sketches. ${ }^{372}$ In contrast, there are no images of the Llandarcy Refinery in the book, and there is only one reference to the facility (the fact that it was completed in 1921) that pre-dates the Second World War. ${ }^{373}$

Several urban historians have investigated the nexus of geography, architecture, and race at the Abadan Refinery, and the ways in which APOC used the built environment to create and sustain unequal power dynamics between British and Persian workforces. ${ }^{374}$ Kaveh Ehsani's work shows APOC's “obsession to use urban space as an

${ }^{371}$ M. Kent, Oil and Empire: British Policy and Mesopotamian Oil 1900-1920 (London: Macmillan, 1976); G. Jones, The State and the Emergence of the British Oil Industry (London: Macmillan, 1981); D. Yergin, The Prize: the Epic Quest for Oil, Money, and Power (New York: Simon, 1992): 132-133, 444, 689; T. Winegard, The First World Oil War (Toronto: University of Toronto Press, 2016): 53, 63, 149.

${ }^{372}$ B. Ritchie, Portrait in Oil: an Illustrated History of BP (London: James \& James, 1995).

${ }^{373}$ Ritchie, 1995, 40. More recently, BP has published accounts of its early history on CD-ROMs, DVDs, and in online repositories. See H. James, B.P. Oil - Llandarcy, 1921-2000. DVD, 2008. ARC 221864; British Petroleum, Oil For the $20^{\text {th }}$ Century. DVD and VHS. No date. West Glamorgan Archives, D/D SIH 1/3; British Petroleum, History of Llandarcy Refinery. DVD. No date. ARC 221865.

${ }^{374}$ For examples, see I. Seccombe and R. Lawless, Work Camps and Company Towns: Settlement Patters and the Gulf Oil Industry (Durham: Centre for Middle Eastern and Islamic Studies, 1987); F. KashaniSabet, Frontier Fictions: Shaping the Iranian Nation, 1804-1946 (Princeton: Princeton University Press, 1999); P. Tabrizian, "From City-Hills to Metropolis: the Origins and Dilemmas of Landscape Urbanism in Iran," N-Aerus XI (2014). A number of recent Ph.D. dissertations have been completed on the historical interaction between APOC and the Iranian, including K. Shafiee, "Cracking Petroleum with Politics: Anglo-Persian Oil and the Socio-Technical Transformation of Iran, 1901-1954.” Ph.D. Dissertation. New York University, 2010; M. Edward Dobe, "A Long Slow Tutelage in Western Ways of Work: Industrial Education and the Containment of Nationalism in Anglo-Iranian and ARAMCO, 1923-1963." Ph.D. Dissertation. Rutgers University, 2008; B. Cooke, "Oil Men: The Twinned Lives of Arnold Wilson and Morris Young." Ph.D. Dissertation. University of East Anglia, 2012; W. Gibson, "British Strategy and Oil, 1914-1923." Ph.D. Dissertation. University of Glasgow, 2012, and R. Alissa, "Building for Oil: Corporate Colonialism, Nationalism and Urban Modernity in Ahmadi, 1946-1992." Ph.D. Dissertation. University of California Berkeley, 2012. 
instrument of controlling the population," while Rasmus Elling's probe into company

housing policies at Abadan reveals that they were designed to transform the region from "an overlooked outpost" into a "symbol of modernity and a hub of development.","375

Rania Ghosn has produced critical research on the politics of urban development by APOC in Persia during the formative years of the company, paying particular attention to the intrusion of pipelines into the mountainous tribal regions in which oil had been found ${ }^{376}$ Nimrod Zagagi has argued that the Abadan Refinery was much more than a place for people to live and work, but rather a powerful tool of segregation and control. "In an area dominated by Arab tribes, a foreign power founded a settlement," he writes, Abadan's townships were "essential venues for the re-education or 'adjustment"” of indigenous workers. ${ }^{377}$ None of these scholars touch upon the Llandarcy Refinery. In his article, “Abadan: Planning and Architecture Under the Anglo-Iranian Oil Company," Mark Crinson explores the daily life in the different workers' villages that surrounded APOC's Persian refinery, concluding that life in Abadan was not unlike the experience in other colonial towns and cities across the British Empire: "a combination of welfare state and British Raj." ${ }^{378}$ While Crinson accounts for APOC's branding of the

\footnotetext{
${ }^{375}$ K. Ehsani, "Making Abadan an Oil Town: 1911-1921," Abadan, Civilization \& Modernity, 28 April 2016. Retrieved from: www.abadancm.com/2016/04/28; R. Elling, "Abadan: Oil City Dreams and the Nostalgia for Past Futures in Iran," Ajam Media Collective, 16-26 February 2015. Ehsani's Ph.D. thesis examined the social history of oil in Abadan through the lens of architecture, and he has since written several blogs about Abadan during the 1910s and 1920s. K. Ehsani, "Boom \& Bust: Social Engineering and the Contradictions of Modernization in Khuzestan's Oil Company Towns, Abadan and Masjed-iSoleyman," Iranian.com, 15 February 2005; K. Ehsani, "The Social History of Labor in the Iranian Oil Industry: the Built Environment and the Making of the Industrial Working Class, 1908-1941." Ph.D. Dissertation. Leiden University, 2014.

${ }^{376}$ R. Ghosn, "The Geographical Footprint of Urbanism: the Trans-Arabian Pipeline and its Hydrocarbon Territory," in B. De Meulder, et al. (eds.), Urbanism and Urbanization: Transcending the Discipline (Leuven: K.U. Leuven, 2009): 153.

${ }^{377}$ N. Zagagi, "Urban Area and Hinterland: the Case of Abadan (1910-1946)," Journal of the Middle East and Africa 7, no. 1 (2016): 64, 73.

${ }^{378}$ M. Crinson, "Abadan: Planning and Architecture Under the Anglo-Iranian Oil Company," Planning Perspectives 12, no. 3 (1997): 341-359. See also M. Crinson, Empire Building: Victorian Architecture and
} 
different villages through promotional activities, particularly efforts to make European neighbourhoods feel "British," he provides no sense of how APOC used the same facility to frame its refined oil products as "Persian." While these scholars do assess the deeper symbolic meanings attached to APOC's Abadan Refinery, and put forward telling critiques of how APOC facilities were used as tools for social control, they offer no sense of how the same facilities were marshalled to influence British oil imaginaries.

One scholar who has investigated APOC's use of architecture as a vehicle for constructing oil narratives and discourses is the film historian Mona Damluji. ${ }^{379}$ Damluji's research analyses the representations of daily life in Abadan through APOC promotional films. In "The Oil City in Focus," she reveals how the company used footage of oil architecture to tell a story of colonial domination of both the Persian landscape and its peoples, while at the same time exalting "oil as the fuel of modern life." ${ }^{380}$ She offers a critical examination of the role that cinema played in shaping APOC corporate narratives about oil, especially with respect to Abadan, but her analysis is centred primarily on one film, the Persian Story (1951), and includes limited references to other contemporary APOC films of the late 1920s and 1930s. Damluji's study, however, provides a useful framework for analysing APOC's promotional activities related to the Llandarcy Refinery, including its construction of images, narratives, and ideas about oil.

Orientalism (London: Routledge, 1996); M. Crinson, Modern Architecture and the End of Empire (Aldershot: Ashgate, 2003); M. Crinson, "Architecture and 'National Projection' Between the Wars," in D. Arnold (ed.), Cultural Identities and the Aesthetics of Britishness (Manchester: Manchester University Press, 2004); M. Crinson, "Imperial Modernism," in A. Bremner (ed.), Architecture and Urbanism in the British Empire (Oxford: Oxford University Press, 2016).

${ }^{379}$ M. Damluji, "Documenting the Modern Oil City: Cinematic Urbanism in Anglo-Iranian's Persian Story," Ars Orientalis 42 (October 2012). See also M. Damluji, "The Oil City in Focus: the Cinematic Spaces of Abadan in the Anglo-Iranian Oil Company's Persian Story," Comparative Studies of South Asia, Africa and the Middle East 33, no. 1 (2013): 75-88.

${ }^{380}$ Damluji, 2013, 79-80. 
Llandarcy was once the most important oil facility in Britain, and yet it has become invisible in the secondary literature. There appears to be no scholarly book or article-length study on the refinery, and those scholars who have assessed the facility have done so in passing, ignoring the role that it played in shaping British oil imaginaries. Energy historians, in particular, have not assessed APOC's promotion of the Llandarcy Refinery as a crucial component of larger British debates about energy and the global transition to oil.

This chapter seeks to offer a richer account of the history of the Anglo-Persian Oil Company during the period 1909-1925. Using oil architecture as an analytical framework and APOC promotional activities as a central body of primary source evidence, the aim of this research is to demonstrate the significant contributions that APOC made to the tapestry of early British petroculture during the Company's formative years. It is framed around these central questions: how did APOC imagine the Llandarcy Refinery, and by what means did the company communicate these ideas to British audiences? What images, stories, and ideas about oil were conveyed in APOC's promotional activities, and how were they informed by larger British conversations about oil? In answering these questions, the chapter argues that APOC must be understood not simply as an oil company that sold goods, but as a conduit for the transmission of knowledge about oil, and an important player and stakeholder in the making of British petroculture during the early 1920s. The refinery and its attendant infrastructure came to represent a leitmotif of the modern age of oil in Britain.

William Knox D'Arcy and the Discovery of Oil at Maidan-i-Naftun, Persia 
On 28 May 1902, the wealthy British financier and gold mining entrepreneur, William Knox D’Arcy, purchased from Mozaffar al-Din, Shah of Persia, the exclusive right to "search for, obtain, exploit, develop, render suitable for trade, carry away and sell" the oil resources of that country. ${ }^{381}$ As the map below makes clear, the D'Arcy Concession was astoundingly large, extending over three quarters of Persia and totalling 1.2 million square kilometres. ${ }^{382}$ [Figure 5]. The deal was to be effective for a period of sixty years, and involved much speculation and financial risk, because it was not known if there were sufficient Persian oil resources to justify an exploratory venture on the scale that D'Arcy envisioned. The financier's tolerance for risk was, however, encouraged by his chief petroleum advisor and friend, Boverton Redwood who, having visited Persia on his tour of emerging oilfields during the 1890s, was certain there were vast stores of petroleum buried beneath the Zagros Mountains. ${ }^{383}$ Drawing upon Redwood's expert geological, commercial, and political advice at every stage of the contractual

\footnotetext{
381 “The Persian Oil Industry," Naft 4, no. 3 (May 1928): 3. William Knox D'Arcy was born in Devon in 1849, and in 1866 he emigrated with his family to Rockhampton, Australia, where he became a successful gold mining financier. In 1889 he returned to Britain, where he lived until his death in May 1917. D. Carment, “D’Arcy, William Knox, 1849-1917," Australian Dictionary of Biography, Vol. 8 (Melbourne: Melbourne University Press, 1981); M. Carnegie, William Knox D'Arcy: Australian Gold and Persian Oil (Melbourne: Kildrummie Press, 1992); R. Brown, "D’Arcy, William Knox," in D. Cannadine (ed.), Oxford Dictionary of National Biography (Oxford: Oxford University Press, 2004). Mozaffar al-Din-Shah, the fifth Persian king of the Qajar Dynasty, ruled from 1896 until his death in 1907. According to an Iranian historian, he was "a weak, pleasure-loving, simple-minded, and considerate king." E. Yarshater, "The Qajar Dynasty [1779-1924]," Encyclopaedia Iranica (15 December 2004).

${ }^{382}$ D'Arcy initially invested $£ 40,000$ of his own money in the Persian Concession. Notable exclusions from the contractual agreement were five northern provinces, near the Caspian Sea, which were left out owing to their proximity to Russia, another expansionist empire seeking to exploit oil at Baku. "Map of Abadan and South West Persia. 1924-1935," Richard Burton Archives, MPKK 1/17/1; R. Ferrier, 1982, 30, 640; M. Brown, "The Royal Navy's Fuel Supplies, 1898-1939; the Transition from Coal to Oil." Ph.D. Dissertation. King's College, University of London, 2006.

${ }^{383}$ In the History of the British Petroleum Company, Ferrier included a full-page photograph of Redwood as the frontispiece for the chapter entitled, "The Funding and Finding of Oil 1901-1908." Ferrier stressed D'Arcy's dependence upon "Dr Redwood for technical advice, as the most distinguished oil technologist of his time." $(1982,48-49)$.
} 
negotiations, D'Arcy acquired the rights to the first foreign oil concession in Persia. ${ }^{384}$

With a stroke of a pen in his London office, the venture capitalist effectively acquired the oil resources of Persia, opening a new chapter in the history of oil in Britain and the Middle East at large. The financier had not set foot in Persia; he never did.

Figure 5: Map of Persia showing extent of D'Arcy Concession

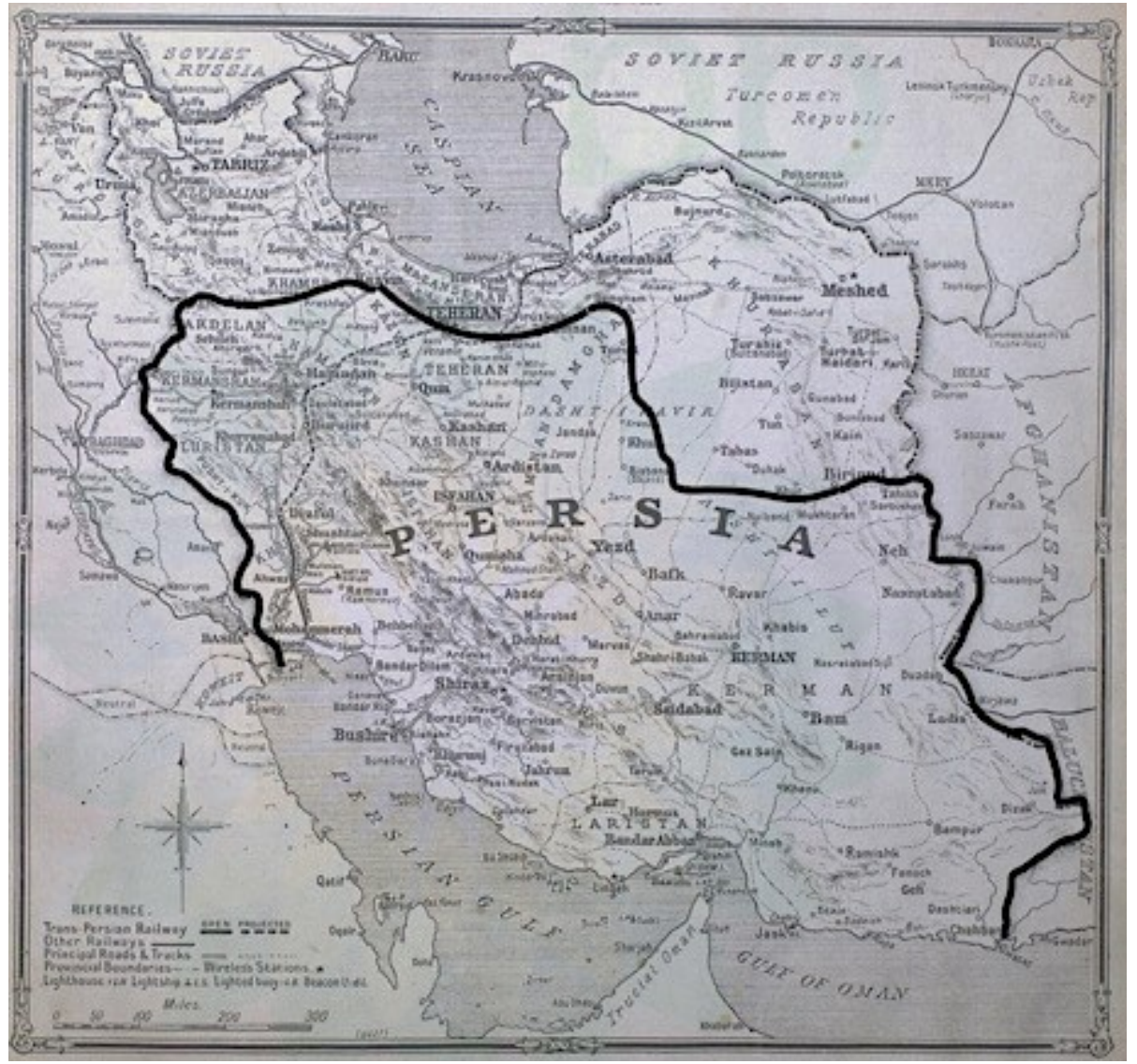

\footnotetext{
${ }^{384}$ The concession contract included several explicit conditions. Upon the first strike of oil, the Shah would receive $£ 20,000$ sterling. If and when a larger company was formed to work any Persian oilfields, the Shah would receive $£ 20,000$ of its shares, and sixteen per cent of all future revenues. For a detailed discussion of the cut and thrust of contract negotiations over the Persian concession, see G. Brew, "In Search of 'Equitability': Sir John Cadman, Reza Shah and the Cancellation of the D'Arcy Concession, 1928-1933," Iranian Studies 50, no. 1 (2017): 125-148; Ferrier, 1994 30-39.
} 
Anglo-Persian Oil Company Photographic Collection, $1926 .{ }^{385}$

D'Arcy's considerable experience in finance and gold mining was not matched by his knowledge of oil. From the outset, he seemed to have been caught off guard by the challenges presented by the natural environment and by the sheer size of the territory he had acquired. ${ }^{386}$ As APOC's official historian has written, the project involved "wildcatting on a colossal scale in a distant and unsettled land. There was nothing comparable to the extent or uncertainty of D'Arcy's Concession." 387 The financier's team of geologists on the ground in the Zagros Mountains struggled for years without finding any oil, in "one of the most underdeveloped and isolated" regions in Persia - a sparsely populated tribal area known as Khuzistan or Arabistan. ${ }^{388}$ As the months passed, the prospects for a quick return on D'Arcy's investment grew dimmer. By 1905, D’Arcy had spent $£ 250,000$ in the search for oil in Persia and had nothing to show for it. ${ }^{389}$ Confronted with bankruptcy, he began to solicit funding from outside sources, both in Britain and in Europe.

Once again, D’Arcy turned to Redwood for guidance. Redwood was convinced that the Persian concession contained oil, and he was equally certain that these resources,

\footnotetext{
${ }^{385}$ Anglo-Persian Oil Company, A Selection of Photographs Depicting the Operations of the Anglo-Persian Oil Company in Persia and South Wales, 1920-1926 (London: The Company, 1926). ARC 36529.

${ }^{386}$ Ferrier observed that "D'Arcy was unaware of the magnitude of the undertaking to which he had committed himself," an assessment based on the fact that he "was not an entrepreneur, he had no engineering experience and little knowledge of Persia. He was an investor who, after consulting his acquaintances and advisers, expected to make a profitable return on his capital." Ferrier, 1982, 43-48. ${ }^{387}$ Ferrier, 1982, 43.

${ }^{388}$ In the early twentieth century, 25 per cent of Iran's population was living in tribal formations, and 80 per cent in rural communities. C. Paine and E. Shoenberger, "Iranian Nationalism and the Great Powers," MERIP Reports 37 (May 1975): 3-28; Zagagi, 2016, 61-64.

${ }^{389}$ For original footage of D'Arcy's team of geologists searching for oil in Persia, see British and Persian Labourers Prospect for Oil, 4:05 minutes, 1900. WPA Film Library, no. 38654.
} 
when discovered, must remain under the control of a British company. Leveraging his professional friendships on the executive board of one of the largest oil companies in Britain, the Burmah Oil Company (BOC), Redwood orchestrated a friendly takeover of D’Arcy's apparently ailing venture in Persia. ${ }^{390}$ Although the BOC buyout provided a much-needed infusion of capital that allowed exploratory work to continue in Persia, no oil was discovered for another three years. For a time, it seemed as though Redwood had missed the mark in Persia. Then, on 26 May 1908, as the company was poised to cut its losses, a team of geologists and drillers led by George Bernard Reynolds discovered a gigantic underground reservoir of oil, 1180 feet beneath the Zagros Mountains, at a place called Maidan-i-Naftun - the Valley of Oil. ${ }^{391}$ The play was one of the largest discoveries in the world to that time, and its size demanded that the BOC create a separate corporate entity that could orchestrate the immense time, energy, and material required to develop a new oilfield from scratch. ${ }^{392}$ In London on 14 April 1909, a group of wealthy and powerful businessmen, as well as numerous public investors, formed the Anglo-Persian

\footnotetext{
${ }^{390}$ Other advisors to D'Arcy included H. T. Burls, W. Dalton, and E. H. Cunningham-Craig. The latter was one of Redwood's "roving geologists" and the discoverer of some of the first oil fields in the Middle East. The financial assistance from Burmah Oil Company came at a heavy cost for D'Arcy, who relinquished his ownership of the Concession in exchange for 170,000 ordinary shares in BOC and recompense for his initial investments in Persia. E. Cunningham-Craig, Oil-Finding: An Introduction to the Geological Study of Petroleum (London: Arnold, 1912): 13; Gloucester Citizen, 7 January 1914, 23; "The Persian Oil Industry," Naft 4, no. 3 (May 1928): 3-6.

${ }^{391}$ Maidan-i-Naftun was also referred to as Masjid-i-Suleiman (Temple of Solomon). The oilfield was located in the valley of the Karun River, the only navigable river in southern Persia, two hundred kilometres northeast of the Euphrates Delta. The strike was made by George Bernard Reynolds, who served as D'Arcy and BOC's Fields Manager from 1901 to 1911. According to one of his biographers, Reynolds was a "man whose initiative, technical skills, and doggedness had opened up the oil riches of the Middle East." T. Corley, "Reynolds, George Bernard (1852/3-1925)," Oxford Dictionary of National Biography, 2004); R. Sorkhabi, "George Bernard Reynolds: a Forgotten Pioneer of Oil Discoveries in Persia and Venezuela," Oil Industry History 11, no. 1 (2010).

392 According to historian Stephanie Cronin, the Persian discovery proved to be "of central and defining importance" in the history of oil in the Middle East. S. Cronin, "Popular Politics, the New State and the Birth of the Iranian Working Class: the 1929 Abadan Oil Refinery Strike," Middle Eastern Studies 46, no. 5 (September 2010): 702-706.
} 
Oil Company with the aim of extracting, refining, transporting, and selling Persian oil products across the world. ${ }^{393}$

In October 1909, less than a year after the initial discovery of oil at Maidan-iNaftun, APOC began construction of a large oil refinery at Abadan, a small island community located on a sandbank in the Shatt al-Arab River delta. ${ }^{394}$ The main complex included several distillation stacks, fracturing benches, machine shops, and testing laboratories and, at locations further downriver, APOC built loading and unloading jetties, pumping stations, and a safe storage site for volatile oil products such as aviation spirits and benzene. ${ }^{395}$ In May 1912 work was completed on the first oil refinery in the Middle East and, shortly thereafter, the ship with the first bulk shipment of Persian crude oil set sail from the Abadan Refinery for Britain. ${ }^{396}$ Importantly for British industrialists and commercial operators, the refinery produced a full spectrum of heavy oil products, including boiler fuels, diesel, kerosene, paraffin, grease, and explosives. ${ }^{397}$ Further expansion of the Abadan Refinery was put on hold during the First World War, when the

\footnotetext{
${ }^{393}$ Anglo-Persian Oil Company, "Report and Abstract of the Receipts and Payments of the Company," 12 July 1909. BP Archives, ARC 128739; N. Fatemi, Oil Diplomacy: Powderkeg in Iran (New York: Whittaker, 1954): 11-17; R. Brown, "D'Arcy, William Knox," in D. Cannadine (ed.), Oxford Dictionary of National Biography (Oxford: Oxford University Press, 2004).

${ }^{394}$ W. Floor, "The Early Beginnings of Modern Abadan," Abadan: Retold, 2017. Retrieved from: www.abadan.wiki/en. The island of Abadan was known locally as Khezr Island, or Jazirat al-Khizr. The sandbar was only a few feet above sea level, and during heavy flooding it became nearly entirely submerged. According to Mark Crinson, Abadan was a "salty infertile island." Crinson, 1997, 342. 395 "Company Meetings," The Times, 22 December 1921, 18. Much of what was known about oil fires and safe storage practices was developed by Boverton Redwood during his tenure as Chief Inspector of the Thames Conservancy. "Sir Boverton Redwood," Glamorgan Gazette, 21 December 1906, 8.

${ }^{396}$ House of Commons Sessional Papers, "Diplomatic and Consular Reports. Persia. Report for the Year Ending March 20, 1911 on the Trade and Commerce of the Province of Arabistan," 1912-1913, vol. 98, Cd. 6005, 6-10.

397 The process of refining crude oil involves multiple stages of distillation. The first round of chemical treatment separates the hydrocarbons into heavy and light fractions: the former are used to create fuel oils, heavy gasses, lubricating oils, paraffin wax, and tar pitch; the latter are used to create benzene and kerosene. To produce motor and aviation spirits, hypochlorite and caustic soda is applied to benzene to wash away the sulphur. Due to the high sulphur content of Persian oil, the Abadan refinery produced mostly heavy oils used for industrial applications and large marine engines. S. Young, Distillation and Principles and Processes (London: Macmillan, 1922).
} 
refinery became the target of several successful attacks by Ottoman gunboats and local Persian militias. ${ }^{398}$ Construction work resumed in 1918, and by the early 1920s Abadan was one of the largest facilities of its kind in the world: it covered an area of five square kilometres, and produced more than 1.3 million tons of oil per year, representative of three per cent of the world's total. ${ }^{399}$

\section{Constructing the Llandarcy Refinery}

There was a singular problem with which both D'Arcy and APOC had grappled since 1901: the producing wells in Persia were located some 10,500 kilometres away from Britain, the primary market for the company's refined oil products. In 1915, APOC formed the British Tanker Company (BTC), which took over the responsibility of shipping Persian oil to Britain. ${ }^{400}$ The long voyage made Persian oil products more expensive, especially when compared to American and Russian products imported from

\footnotetext{
${ }^{398}$ In the spring of 1914, British and Indian troops were dispatched to protect Abadan from Ottoman attacks. In February 1915, Ottoman troops incited a local Bakhtiari uprising, in which "jihadists" sabotaged Anglo-Persia's pipelines. The company repaired the line and stationed troops, but the attackers struck again, two weeks later, at another location. House of Commons Debate, "Persia," 21 July 1914, vol. 65, cc. 232-236; P. Sykes, "South Persia and the Great War," Geographical Journal 58, no. 2 (August 1921): 101116; Anglo-Iranian Oil Co., The Record of the Anglo-Iranian Oil Co., Ltd., Vol. 1, 1901-1918 (London: The Company, 1938): 269, 274.

399 "Company Meetings," The Times, 22 December 1921, 18; Imperial Institute, Petroleum (London: John Murray, 1921): 63. Persian crude oil production totalled 84,000 metric tons in 1913, and 1,369,000 tons in 1920. By comparison, in 1920 the production of oil in the United States totalled 59 million tons; in Mexico 23 million tons; in Russia 3.5 million tons, and in Canada 29,000 tons. A. Dunstan (ed.), The Petroleum Industry (London: Institute of Petroleum Technologists, 1922): 323, 330; M. Mitzakis, The Oil Encyclopaedia (London: Chapman, 1922): 394.

${ }^{400}$ Prior to the formation of the BTC, APOC transported its oil products using several British and European shipping companies. In 1919, the BTC had twenty-five oil-carrying vessels, which represented five per cent of the world's tankers by number and twenty-eight per cent by displacement/weight. From 1916-1929, a total of eighty-five oil tankers were built by the company. "Tanker Building Programme Complete," Naft 5, no. 2 (March 1929): 11-13. On the history of the BTC, see C. Bonn, The Oil Tanker (London: Association of Engineering and Shipbuilding Draughtsmen, 1922); W. Harvey and R. Solly, BP Tankers: a Group Fleet History (London: Chatham, 2006); BP Shipping, Riding the Waves: BP Shipping, 1915-1925 (London: the Company, 2015).
} 
much closer oil fields. ${ }^{401}$ Yet the most serious challenge posed by the geographical separation between the sites of production and consumption was climatic. While Persian crude oil could be transported in tankers to ports around the world, the "light fractions" of highly refined petroleum products made at Abadan, such as kerosene, benzene, aviation fuel, and motor spirits, broke down as a result of the significant changes in temperature that occurred during the journey from the $30^{\text {th }}$ parallel to the $51^{\text {st }} .{ }^{402}$ As the appetite for refined oil in Britain grew steadily over the 1910s, particularly with respect to motor spirits, the need to supply British consumers with products of a consistent quality became apparent. During the First World War, what was formerly a commercial inconvenience became a national security concern as the German campaign of unrestricted submarine warfare effectively neutralized APOC's ability to ship Persian crude oil to Britain. ${ }^{403}$ In 1915, APOC began work on its second major oil refinery, and the first to be built in Britain. A subsidiary company, National Oil Refineries, Ltd., was created to manage the project, and in the spring of 1917 ground was broken on a swampy, fallow plot of land on the outskirts of the small Welsh town of Skewen. ${ }^{404}$ The following year, a

401 J. Henry, Baku: an Eventful History (London: Constable, 1905).

${ }^{402}$ For a discussion of the historical development of oil-carrying watercraft, see J. Dodds Henry, ThirtyFive Years of Oil Transport: The Evolution of the Tank Steamer (London: Bradbury Agnew, 1907), and C. Zulver, "The Modern Tanker," in A. Dunstan (ed.), The Science of Petroleum (Oxford: Oxford University Press, 1938): 795-802.

${ }^{403}$ According to some historians, the German submarine campaign was intended primarily to diminish the supply of oil to Britain and France. J. Devanney, The Tank Ship Tromedy: The Impending Disasters in Tankers (Tavernier, FL: CTX Press, 2006): 18-19. During the war, hundreds of Allied oil tankers were sunk as they travelled from Persia to Britain. APOC's tanker losses during the First World War were light compared to other oil companies, with just eighteen seafarers and two ships lost. In contrast, the company lost more than half of its fleet during the Second World War. C. Jones, "Oil on the Caribbean and Elsewhere," North American Review 202, no. 719 (October 1915): 536-543; F. McKee, 'Sink All the Shipping There': The Loss of Canada's Wartime Merchant Ships and Fishing Schooners (St. Catherine's: Vanwell, 2004).

${ }^{404}$ The plot covered 650 acres, and was purchased by APOC from a local farmer, John Williams, for $£ 450$. "Agreement between APOC and Neath Rural District Council," 31 December 1917. BP Archives, ARC 179436-74; "Llandarcy Oil Refinery, Journal," 1919-1921. Richard Burton Archives, LAC/66/A1; E. Smith, "The Locality of Llandarcy," Transactions of the Neath Antiquarian Society 7 (1937): 30-32. 
spur line of the Great Western Railway was completed, which permitted an accelerated building schedule and access to a larger workforce. ${ }^{405}$ In July 1920, after three years of construction, the primary components of the refinery were brought online for testing. In March 1921, a BTC tanker named British Princess delivered the first shipment of Persian crude oil to the APOC facilities at the Queen's Docks, in Swansea. ${ }^{406}$ The shipment was a momentous episode in APOC's corporate history, completing the link that connected Abadan and Llandarcy, Persia and Britain. More broadly, the delivery marked the beginning of a new period in the history of the British oil industry, since it was among the first cargos of foreign crude oil to be refined in Britain. ${ }^{407}$ The total cost of the refinery was $£ 3$ million, which in 2017 would be the equivalent of approximately $£ 142$ million. ${ }^{408}$ Unlike the company's Persian refinery, which had been named after the island on which it was located, APOC created an entirely new name for its second refinery Llandarcy. The name was a hybrid of the English and Welsh languages. The prefix "Llan" was drawn from the Welsh language, which signifies a village or lawn, and

\footnotetext{
${ }^{405}$ In total, APOC employed 3,000 people at the Llandarcy Refinery.

${ }^{406}$ It took approximately 12 hours to discharge an oil tanker of 10,000 tons displacement. During the early 1920s, APOC's Swansea docks could accommodate three of such tankers simultaneously. "Oil from Persia," Dundee Evening Telegraph, 30 March 1921, 4; "Oil Refining in Great Britain," Modern Transport, 1 July 1922, 3; "A New Industry Opened," The Times, 30 June 1922, 19; C. Bonn, The Oil Tanker (London: Association of Engineering and Shipbuilding Draughtsmen, 1922).

${ }^{407}$ Workers who lived outside of the Skewen area commuted to Llandarcy on a company-operated railway service, which included stops at Glamorgan, Swansea Docks, and Lonlas Signal Box. "Agreement between APOC and GWR," 10 August 1918. BP Archives, ARC 179436-37; "Agreement with the British Steel Corporation to Sell Land at Llandarcy," 1919. West Glamorgan Archives, D/D BF/E 785; "Llandarcy: Record of Workforce Wage Rates," 1919-1922. Neath Antiquarian Society Archives, NAS Z 16/31.

${ }^{408}$ The cost of the refinery, some of which was paid for by the taxpayer, aroused considerable debate at the time, with businessmen levelling accusations that the project was secretly over-budget by millions of pounds. "Llandarcy Oil Plant," The Engineer, 1 April 1921, 345; "Hopeful Prospects," Sunday Times, 27 August 1922, 2; "The Llandarcy Refinery of the Anglo-Persian Oil Company," Chemistry and Industry, 18 May 1923, 483; House of Commons Debate, "Anglo-Persian Oil Company," 14 March 1922, vol. 151, cc. 2129-2142. A report published in The Engineer noted that "[g]reat reticence is still being observed" about the financial details of the refinery. "A Seven-Day Journal," The Engineer, 1 April 1921, 345. The rumours forced APOC Chairman Sir Charles Greenway to write a rebuttal in "Oil Power," The Times, 9 November 1921,8 .
} 
"darcy" paid homage to APOC's patriarch, William Knox D'Arcy. ${ }^{409}$ The name had been crafted by APOC's Chairman, Sir Charles Greenway, with the help of Ernestine Nutting, the second wife and widow of D'Arcy, who had died in May $1917 .{ }^{410}$

The Llandarcy Refinery was approximately half the size and output of Abadan. In many ways it was an experimental facility that produced a range of highly refined, boutique oil products. The site included a special laboratory in which petrochemical experiments were carried out using miniature, scale-model prototypes, and was protected from fire by a system of innovative steam-powered "fireless locomotives," colloquially referred to as Thermos Flasks. ${ }^{411}$ [Figure 8]. The facility was comprised of several distillation stacks and fracturing benches, as well as workshops, water towers, holding tanks, and laboratories. ${ }^{412}$ On the north-west corner of the property was a large storage tank farm containing thirty-three cylinders, which could hold up to ninety million gallons of oil. ${ }^{413}$ Adjacent to the tank farm was an 11-acre drainage bed, named Crumlyn Bog, which was kept undeveloped in case of an oil spillage. ${ }^{414}$ The refinery was connected to

\footnotetext{
409 “A Seven-Day Journal," The Engineer, 1 April 1921, 345. Innumerable communities in Wales feature the prefix "Llan" in their names, including Llanelli; Llanddeiniol; Llanybydder, and the village of Llan. On naming and nicknaming in the British context, see What's in a Name? BBC 2 Wales, 18 September 2007; R. Wilson, “Tommifying' the Western Front, 1914-1918," Journal of Historical Geography 37, no. 3 (July 2011): 338-347.

${ }^{410}$ In his correspondence with Nutting, Greenway noted that there was "no hurry in naming" the other components of the Llandarcy Refinery. Naming the central avenue of the workers' village The Greenway, however, was "quite all right." "D. Garrow to Col. A. Leslie, 24 February 1921," General Company Letter Book, No. 9. BP Archives, ARC 54506.

411 "The Llandarcy Refinery of the Anglo-Persian Oil Company," Chemistry and Industry, 18 May 1923, 485-486. Photographs of the Thermos Flask can be found in British Petroleum, The Llandarcy Refinery, 1922. ARC 209171; Anglo-Persian Oil Company, A Selection of Photographs Depicting the Operations of the Anglo-Persian Oil Company in Persia and South Wales, 1920-1926. ARC36529; Anglo-Persian Oil Company, Collection of Back and White Negatives, 1924. ARC 209175.

412 "Plan of Swansea Harbour, Queen's Docks, and Llandarcy Refinery: Industrial Development by APOC," 1915-1919. ARC 195848.

${ }^{413}$ The tank farm was comprised of tanks of varying sizes: twenty-five containers of 10,000 tons, for storing crude oil; four containers of 5,000 tons, for storing kerosene, and four containers of 5,000 tons, for storing motor spirit. H. Morton, In Search of Wales (London: Methuen, 1932).

${ }^{414}$ National Oil Refineries, "General Ledger," 1922-1932. BP Archives, ARC 93632/ARC 195847.
} 
the Port of Swansea via a series of pipelines, which delivered Persian crude oil from the unloading facilities located at the Queen's Docks, several kilometres to the southwest. ${ }^{415}$ The infrastructure projects undertaken by APOC at Llandarcy transformed the region into the largest oil hub in Britain and one of the busiest in the world.

Other critical components of the Llandarcy Refinery were the two model villages built for essential process staff and upper management. ${ }^{416}$ As the Aberdeen Press and Journal reported in 1921, the construction of the refinery had also given rise to the "new oil town" of the future, in which residents could live in the comfort and convenience provided by oil. ${ }^{417}$ The worker's villages were divided into separate neighbourhoods located at opposite ends of the refinery grounds. Twenty homes were constructed at Cefn Park, two kilometres to the northeast, where senior management staff lived in spacious, two-storey dwellings that combined the architectural styles of English Art Deco, the Arts and Crafts Movement, Georgian Revivalism, and 'Tudorbethanism.' 418 [Figure 9]. Each house was decorated in red brick or white stucco and had a large garden that fronted on to a broad central avenue. The entire community was surrounded by a woodlot maintained

\footnotetext{
${ }^{415}$ At the Port of Swansea, three new jetties were added to the existing docks, as well as a lighthouse and a tank farm with a capacity of twenty-one million gallons. "New Industry Opened," The Times, 30 June 1922, 19; National Oil Refineries, "Journal No. 9," 1921-1922. Richard Burton Archives, LAC/66/A/12; Anglo-Iranian Oil Company, Llandarcy Refinery, South Wales (London: the Company, 1935): 2. 416 Anglo-Persian Oil Company, Llandarcy: England's New Industry (London: the Company, 1922); British Petroleum, Llandarcy Refinery, South Wales (London: the Company, 1935). For a discussion of model villages in Britain during the period, see "Town Planning," British Medical Journal 1 (February 1914): 391; G. Cherry, "The Town Planning Movement and the Late Victorian City," Transactions of the Institute of British Geographers 4, no. 2 (1979): 306-319; C. Buckley, "Modernity, Tradition and the Design of the 'Industrial Village' of Dormanstown, 1917-1923," Journal of Design History 23, no. 1 (2010): 21-41.

417 "Persian Oil for Britain," Aberdeen Press and Journal, 30 March 1921, 5.

${ }^{418}$ For a discussion of English architecture during this period, see N. Whiteley, "Modern Architecture, Heritage and Englishness," Architectural History 38 (1995): 220-237; "Design of the Period House, 19201929,” Bricks \& Brass, 2014. Retrieved from: www.bricksandbrass.co.uk.
} 
by the company. ${ }^{419}$ One of the finest examples of APOC's residential architectural style could be found in Cefn Lodge, the residence of the Llandarcy Refinery General Manager, which exhibited a symmetrical design vaguely suggestive of the prestige and power of British country estates.

Middle-management, essential process workers, and members of the fire and police service were housed in a model village situated one kilometre to the southwest of the refinery. Named Llandarcy Village, this community was significantly larger than Cefn Park, and was composed of 100 private residences of detached and semi-detached designs. ${ }^{420}[$ Figure 10]. The houses were arranged in the style of a garden city, spaced evenly along broad, winding streets named after influential figures in APOC's corporate history - "The Greenway" and "Pretyman Drive" being two notable examples. ${ }^{421}$ The residences at Llandarcy Village used a half-timbered style that combined red stone and brick, bright white stucco, and exposed wooden beams. The design of these homes was executed as a hybrid of traditional and modern architectural styles, seeking both to fit in

\footnotetext{
${ }^{419}$ National Oil Refineries, "Llandarcy Village: Elevations," [c.1918]. West Glamorgan Archives, WGCC/EH 16/6; "Llandarcy Village Street Plans," 1921-1923. Neath Antiquarian Society Archives, NAS Z 21/23; Anglo-Iranian Oil Company, Llandarcy: A Survey (London: the Company, 1937): 1.

${ }^{420}$ The model village cost a total of $£ 273,424$ to construct, equivalent in 2018 to $£ 12.5$ million. "The New Oil Village: Anglo-Persian Company’s Great Scheme," Manchester Guardian, 12 June 1922, 10; "Llandarcy Refinery," Cambria Daily Header, 29 June 1922; National Oil Refineries, "Estate Rentals," [c.1922]. Richard Burton Archives, LAC/66/C/1.

${ }^{421}$ Sir Charles Greenway (1857-1934) was a senior employee in the Burmah Oil Company during the 1890s. In 1910 he was appointed Director of APOC, and in 1914 he became the company's Chairman. He was made a Baron in 1919 for his service in providing oil during the war and bestowed with the Order of the Lion and Sun by the Shah of Persia. "Oil-Refining in Great Britain," Modern Transport, 1 July 1922; T. Corley, "Greenway, Charles, first Baron Greenway (1857-1934)," in D. Cannadine (ed.), Oxford Dictionary of National Biography (Oxford: Oxford University Press, 2004). Ernest G. Pretyman was Civil Lord of the Admiralty (1900-1903, 1916-1919) and largely responsible for arranging Burmah Oil's financing of the D'Arcy Concession in 1905. Pretyman was a close personal friend of Boverton Redwood, with whom he served on the Inter-Departmental Committee on Petroleum Products from 1917-1918. "Llandarcy Refinery and Village," Photographic Collection, [c.1922]. West Glamorgan Archives, D/DZ 201/23-25; Ferrier, 1982, 60, 68, 106, 122.
} 
with the green backdrop of the surrounding fields and copses, while at the same time standing out as symbols of cleanliness, orderliness, and modernity. ${ }^{422}$

The lifestyle enjoyed by residents of Llandarcy Village was revealed in similar terms. Leisure activities and the time needed to indulge in them abounded, a fact that is evident in many of the memoirs and autobiographies of former employees. ${ }^{423}$ APOC operated a social club, called the Llandarcy Institute, which staged children's parties, theatrical performances, dances, and other community events. ${ }^{424}$ A well-funded sports club was also popular among residents, who could enjoy games of tennis, badminton, and cricket. Lawn bowling could be played on a green "acclaimed as one of the best in the country. ${ }^{425}$ In concert with these modern activities, Llandarcy Village also offered residents the chance to engage in more traditional pursuits, such as yeoman farming on the company's plot of seventy acres, or the growing of fresh produce for the Gardening Society's market stand. ${ }^{426}$ The adventurous resident could go for a hike through the old grounds of the Cwrt-y-Bettws Colliery, which had been bought by APOC and left vacant but intact. $^{427}$

\footnotetext{
${ }^{422}$ The Llandarcy Refinery was the target of frequent bombing raids during the Second World War. To improve workers' safety, the houses at Llandarcy Village and Cefn Park were painted green, and the streets were coated in green and black stone chips; the roofs of the storage tanks, some 25 acres in total, were covered with steel wool, asbestos, and coloured stone chips, and shrubs were planted across 100 acres of ground. There were no casualties at the refinery during the war. "Queen's Visit to Villagers," Western Mail, 16 November 1945, 1; "Royal Visit to Wales," The Times, 16 November 1945, 2; T. Stradling, The National Oil Refineries, Llandarcy (Swansea: the Author, 2005): 6.

${ }^{423}$ Shiela Jones's memoir recounted a schedule of daily activities provided for village residents, as well as special events held on weekends and holidays. Similar accounts were made in Vivian Griffiths' memoir. S. Jones, Spanning the Years (Self-published, c.2004); V. Griffiths, Llandarcy Remembered (Neath: Bryngold, 2007).

424 "Presentation of a Persian Play at Llandarcy," Naft 2, no. 3 (May 1926): 28; BBC News, "Llandarcy: Down to the Last Drop," 2 December 2009. Retrieved from: www.news.bbc.co.uk/local/southwestwales/hi/people_and_places/history/newsid_8389000/8389503.stm. ${ }^{425}$ Anglo-Iranian Oil Company, Llandarcy: A Survey (London: the Company, 1937): 5. 426 "The Llandarcy Refinery of the Anglo-Persian Oil Company," Chemistry and Industry, 1922, 486. 427 "Skewen Pit Manager's New Appointment," Western Mail, 1 January 1915, 5; “Wales by Day," Western Mail, 18 May 1917, 4; Stradling, 2005, 13.
} 
Life in Cefn Park and Llandarcy Village was comfortable, convenient, and leisurely. These villages were critical to the functioning of the refinery, and they symbolized the oil-fuelled way of life that was beginning to take hold in certain parts of Britain. Yet, despite their historical importance, the model villages at Llandarcy have been practically written out of the secondary literature. The villages are not even acknowledged in Ferrier's History of the British Petroleum Company, in which dozens of pages and numerous photographs are dedicated to the early history of the Abadan Refinery. ${ }^{428}$ The invisibility of the model villages in the existing literature is indicative of the larger historiographical neglect suffered by Britain's first petrochemical refinery. In the history of oil in Britain, there is no other facility that carries as much importance.

\section{Oil Architecture and the Promotion of the Llandarcy Refinery}

In the weeks and months that followed the completion of the Llandarcy Refinery, APOC initiated a multi-phase promotional campaign to draw attention to the groundbreaking facility and the new consumer products it was making. Through a variety of means, the refinery was leveraged as tool for communicating ideas about oil and its future in Britain. These promotional activities were intended not only to build awareness of the APOC brand and the products that the company sold, but also to highlight the modern science and technology that brought them to life. In more abstract ways, the Company's promotional activities provided information that helped audiences to make sense of oil. In creating this archive of oil images, stories, and ideas, APOC made important contributions to the development of British petroculture during the early 1920s.

\footnotetext{
${ }^{428}$ Ferrier, 1982, 776.
} 
One of the first promotional activities undertaken by APOC for the Llandarcy Refinery was the hosting of a grand opening ceremony. Held on 29 June 1922, the event brought together some of the most influential personalities in the British world of oil, including Sir John T. Cargill, Chairman of the Burmah Oil Company; ${ }^{429}$ Viscount Cowdray, the Mexican oil magnate, ${ }^{430}$ Sir Frederick Black, former President of the Institution of Petroleum Technologists; Viscount Churchill of Wychwood, the Chairman of the Great Western Railway; Sir John Cadman, wartime Director of His Majesty's Petroleum Executive and future APOC Chairman, ${ }^{431}$ and Stanley Baldwin, the President of the Board of Trade (and soon-to-be Prime Minister). ${ }^{432}$ King George V was extended an invitation, which he declined, but His Excellency Prince Farid-es-Saltaneh attended on behalf of the Persian royal family. ${ }^{433}$ Also on the guest list was Captain Lionel K. D’Arcy, R.N., the only surviving son of William Knox D'Arcy.

The ceremony was in every way an oil spectacle. With its full day schedule of activities, the event was a carefully orchestrated performance designed to showcase APOC's mastery over the science and technology of oil refining, while at the same time providing a means of transmitting the Company's narratives about the future of oil to a targeted, hand-picked audience. In the morning, a special direct train service from

${ }^{429}$ T. Corley, "Cargill, Sir John Traill, first baronet (1867-1954)," in D. Cannadine (ed.), Oxford Dictionary of National Biography (Oxford: Oxford University Press, 2004).

${ }^{430}$ G. Jones, "Pearson, Weetman Dickinson, first Viscount Cowdray (1856-1927)," in D. Cannadine (ed.), Oxford Dictionary of National Biography (Oxford: Oxford University Press, 2004).

${ }^{431}$ H. Torrens, "Cadman, John, first Baron Cadman (1877-1941)," in D. Cannadine (ed.), Oxford Dictionary of National Biography (Oxford: Oxford University Press, 2004).

${ }^{432}$ S. Ball, "Baldwin, Stanley, first Earl Baldwin of Bewdley (1867-1947)," in D. Cannadine (ed.), Oxford Dictionary of National Biography (Oxford: Oxford University Press, 2004).

433 “New National Industry. Swansea’s Future," Western Mail, 30 June 1922. In May 1922, Greenway invited the Secretary of State for the Colonies, Winston Spencer Churchill, to the grand opening ceremony of the Llandarcy Refinery. Churchill declined, but sent the President of the Board of Trade, Stanley Baldwin, as the Government's representative. "Letter from Churchill to Greenway," 9 May 1922. ARC 94098; "Letter from Stanley Baldwin to Greenway," 24 May 1922. ARC 94098. 
London arrived at Llandarcy carrying a group of British journalists. They disembarked and started a guided walking tour of the refinery grounds, directed by the facility's Works Manager, A. M. O’Brien. ${ }^{434}$ As the group of reporters made their way through the various components of the refinery - twelve stops, in all, including the distillation stacks, testing laboratories, storage warehouses, tank farm, and model village - a second party of guests travelling from London arrived at the Llandarcy terminal. This party, which included distinguished guests and government representatives, was greeted by APOC's Chairman, Sir Charles Greenway. ${ }^{435}$ At noon, the two groups of visitors congregated in the wax storage room for a luncheon presided over by Greenway and Stanley Baldwin. ${ }^{436}$ Just over three hundred guests were seated, and according to the Western Mail, the room contained "probably the most influential group of financiers and industrial magnates who have ever come together in South Wales." ${ }^{437}$

After their meal, the guests listened to speeches from the APOC Chairman and the President of the Board of Trade, each of whom delivered messages redolent of Sir Boverton Redwood's oil lectures. ${ }^{438}$ Greenway stressed the dangers faced by D'Arcy's geologists in Persia, and he praised the perseverance that had fuelled one of the most

\footnotetext{
${ }^{434}$ South Wales Evening Post, 29 June 1922. The tour was partially led by the Director of the British Petroleum Company's Publicity Department, Peter Donovan, who also led tours at the company's Persian Khan exhibit, held at the British Empire Exhibition in 1924 and 1925. See Chapter 4.

${ }^{435}$ Guests on the second train included Viscount Cowdray; Sir Alfred Moritz Mond; Admiral Sir Edmund Slade; Sir George Barstow; Sir Louis Kershaw; Sir Edward H. Packe; Brig.-Gen. H. Bagnall-Wild; Sir George Barnes; Field Marshal Sir Arthur Barrett; Sir T.J. Bennett; Sir Frederick Black; Lord Blythswood; Professor J.S. Brame; Sir Arthur Whitten Brown; Cecil Campbell; Sir Travers Clarke; Sir Alexander Cobb; Sir Arthur Corey-Wright; Sir Joseph Davies; Lord Deynevor; Sir Sam Fay; Sir Thomas Holderness; Sir Thomas Holland, and Sir Percy Sykes.

${ }^{436}$ The wax storage room was used to store tubs of paraffin during the conversion process from a liquid to a solid. The room was "tastefully decorated" by Messrs. David Evans, of Swansea. South Wales Evening Post, 29 June 1922; Anglo-Persian Oil Company, A British Oil Industry: Stereoscopic Views of the Oil Refinery in South Wales (Llandarcy) and Distribution Centre in London (London: the Company, 1924). 437 "New National Industry. Swansea's Future," Western Mail, 30 June 1922.

${ }^{438}$ Anglo-Iranian Oil Company, Llandarcy Refinery, South Wales (London: the Company, 1935): 2.
} 
important discoveries of oil ever made, fulfilling a "great national purpose." ${ }^{439}$ A thread running throughout Greenway's address was APOC's development of modern science and technology, and its global empire of oil architecture, which connected peoples and cultures across vast distances. Baldwin rose next to speak, expressing his appreciation of APOC's refinery and its creation of jobs "not only for the hands of the country, but for the brains of the country." ${ }^{440}$ Baldwin noted that the oil industry in general "was an industry which depended very largely upon trained brains," and the Llandarcy Refinery was proof there were "no brains in the world to beat the brains in these islands for technical purposes." APOC had created at Llandarcy a modern refinery that held the potential to revolutionize the British oil industry, Baldwin concluded, and that would surely mark "an epoch in the history of the oil trade of the world." 441

The entertainment continued in earnest after the speeches. According to local news reports, two Welsh employees unexpectedly took to the stage, one "with his tin food-box under his arm," to sing the Welsh national anthem, "Hen Wlad Fy Nhadau [The Land of my Fathers]." 442 In its report of the event, the Cambria Daily Header wrote that the "distinguished company thus witnessed a characteristic of Welsh life." ${ }^{443}$ Next, the guests moved outside to witness Baldwin lay a ceremonial foundation stone at the base of the refinery's central offices, and a panoramic group photograph was taken. ${ }^{444}$ The delegation of distinguished guests that had arrived on the second train was given a guided

\footnotetext{
439 "New Industry Opened," The Times, 30 June 1922, 19; Westminster Gazette, 30 June 1922; "The Oil Refineries at Llandarcy," Manchester Guardian, 30 June 1922, 11.

440 "New British Industry," Yorkshire Post, 30 June 1922; The Times, 30 June 1922, 19; “Great Oil

Refinery at Swansea," Scotsman, 30 June 1922, 5.

441 “The Anglo-Persian Company’s New Refinery," Petroleum Times, 1 July 1922.

${ }^{442}$ For a rendition of "Hen Wlad Fy Nhadau," see www.youtube.com/watch?v=3kUnCwV3AYE.

443 “Skewen Singer," Cambria Daily Header, 30 June 1922.

${ }^{444}$ After the foundation stone was laid, Greenway revealed a special inauguration stamp commissioned for the occasion. Anglo-Persian Oil Company, "Llandarcy Refinery Inauguration Stamp," 1922. ARC 32103.
} 
walking tour of the refinery, conducted by Greenway, Baldwin, and the Works Manager. To assist attendees in making sense of what they were seeing and hearing, APOC distributed samples of oil products held in glass vials, as well as a small pamphlet with a hand-drawn map of the refinery, storage tank farm, and model villages. ${ }^{445}$ Pictures were taken throughout the tour, with the photographer capturing images of Viscount Churchill, Viscount Cowdray, and Cecil Campbell sniffing oil, and of Greenway riding a Thermos Flask fireless locomotive engine. ${ }^{446}$ At the conclusion of their walking tour, the guests embarked on a train for London, having just explored the first oil refinery in Britain.

For the journey home, tea and a dinner were laid on by the company, and an illustrated souvenir booklet, entitled "Llandarcy: England's New Industry," was distributed to each traveller. ${ }^{447}$ Inside, readers could find a record of the information they had been given that day, as well as a number of maps, diagrams, and drawings of the major sites they had visited. ${ }^{448}$ The presentation of the booklet was particularly attractive. The front cover featured an artist's interpretation of the Llandarcy Refinery executed in a three-tone colour scheme, which displayed a Thermos Flask engine, cylindrical storage tank, and series of pipelines in the foreground, and warehouses, rail cars, and the refinery behind. The booklet contained a strategic combination of information and artwork, education and entertainment. It told the story of APOC's triumphant rise to commercial prominence, and boasted of the company's leadership role in manufacturing a reliable

\footnotetext{
445 "Programme of the Opening Ceremony at the New Refinery of the National Oil Refineries Ltd. at Llandarcy by the Right Hon Stanley Baldwin President of the Board of Trade,” 29 June 1922. ARC 094102.

446 "Photograph: the Llandarcy refinery," 30 June 1922. ARC 209171-ARC 209170.

447 “Llandarcy Refinery," Petroleum Times, 1 July 1922.

${ }^{448}$ Anglo-Persian Oil Company, Llandarcy: England's New Industry (London: the Company, 1922). Very few copies of the pamphlet appear to exist. See British Petroleum Archives, ARC 066856; National Archives (UK), RAIL 258/233; West Glamorgan Archives, D/D Z 212/2.
} 
supply of oil products for the British consumer. At Llandarcy, the booklet asserted, APOC had built a "plant which embodies all the latest improvements, and which in layout, efficiency, and economy of operation takes second place to no plant of its kind in the world." ${ }^{449}$ The refinery filled "a great gap in [Britain's] national industrial equipment," and initiated "an entirely new industry in this country." 450

The motif of modern oil architecture was at the heart of the souvenir booklet. Several black and white photographs and hand drawn illustrations depicted the various components of the facility, and the centrefold pages were filled with a large painting that showed a bird-eye view of the Llandarcy Refinery, Cefn Park, Llandarcy Village, and Queen's Docks. [Figure 11]. In the text, readers learned of the "huge steam turbogenerators" used to power the facilities, and of the "object lesson in the efficiency and convenience of this modern method of steam raising." ${ }^{451}$ The booklet described the refinery's two model villages as having the "characteristics of a pleasant garden suburb...picturesquely placed on rising ground," and it claimed that residents lived in "commodious and comfortable houses," enjoyed active social lives, and participated in traditional pursuits at the "home farm of seventy acres." ${ }^{\text {" } 52}$ Llandarcy was "a complete modern refinery," which produced the "finest and most uniformly dependable spirit to be obtained. Every resource of refining science has been called in to ensure the perfect uniformity of this spirit." ${ }^{\prime 453}$

${ }^{449}$ Llandarcy: England's New Industry, 1922, 7, 13.

${ }^{450}$ Llandarcy: England's New Industry, 1922, 17.

${ }^{451}$ Llandarcy: England's New Industry, 1922, 15-16.

${ }^{452}$ Llandarcy: England's New Industry, 1922, 17.

${ }^{453}$ Llandarcy: England's New Industry, 1922, 5, 19. 
The most creative means by which APOC communicated with readers of the booklet was delivered in a black and white drawing that appeared on the inside covers. [Figure 6]. Taking up the left-hand side of the drawing is the figure of the Greek god Hermes, dressed in a loin cloth, winged sandals, and a winged helmet. He carries a caduceus in his left hand, a staff topped with wings and serpents entwined around its shaft. ${ }^{454}$ In classical mythology, Hermes functions as a messenger of Zeus, his father, and is known for his swiftness and efficiency. ${ }^{455}$ In other iterations of Hermetic mythology, the winged god is associated with transportation, technical expertise, borderlands, and moments of transition and change. ${ }^{456}$ Opposite to Hermes, on the inside back cover of the booklet, was a characterisation of Prometheus, who took the form of a bare chested, muscled man. In classical mythology, Prometheus was a Titan who stole fire from the gods and gave it to humans. ${ }^{457}$ As punishment, Zeus chained Prometheus to a boulder, and later he sent Hermes to deliver an eagle that would continually gnaw at Prometheus' liver. The Titan exemplifies steadfastness and determination in the face of adversity, and has come to symbolize the themes of progress and development in science and technology. ${ }^{458}$ These narratives resounded in APOC's promotional booklet. In the cover illustration, Prometheus is bound at the wrists and fastened to the mountains beneath him, yet he appears to be in a state of resistance, poised to break free of the ropes that hold him

\footnotetext{
${ }^{454}$ S. Yona, "What About Hermes? A Reconsideration of the Myth of Prometheus in Plato's Protagoras," Classical World 108, no. 3 (Spring 2015): 366-368. The caduceus is the traditional symbol of physicians.

${ }^{455}$ R. Harris, "Hermes Iconography in Communications and Commerce: Semiotics of Cultural Networks," The Ephemerist 159 (December 2012): 6-12.

${ }^{456}$ N. Brown, Hermes the Thief (Madison: University of Wisconsin Press, 1947); E. Hirsch, et al. (eds.), "Hermes," The New Dictionary of Cultural Literacy (Boston: Houghton Mifflin, 2002).

${ }^{457}$ E. Hirsch, et al. (eds.), "Prometheus," The New Dictionary of Cultural Literacy (Boston: Houghton Mifflin, 2002).

${ }^{458}$ A. Mitzman, Prometheus Revisited (Boston: University of Massachusetts Press, 2003); C. Dougherty, Prometheus (London: Routledge, 2006): 119.
} 
down. At the base of the mountain are three oil derricks, and an oil tanker making its way towards the refinery on the left-hand side of the illustration. The dramatic image narrated the unchaining of Prometheus, and the release of the immense power trapped beneath the mountain he rested upon. ${ }^{459}$ The unlocking of Persian oil was presented as a monumental, god-like achievement, one that promised completely to transform everyday human life on the ground.

Figure 6: Illustration of Hermes and Prometheus from Llandarcy souvenir booklet
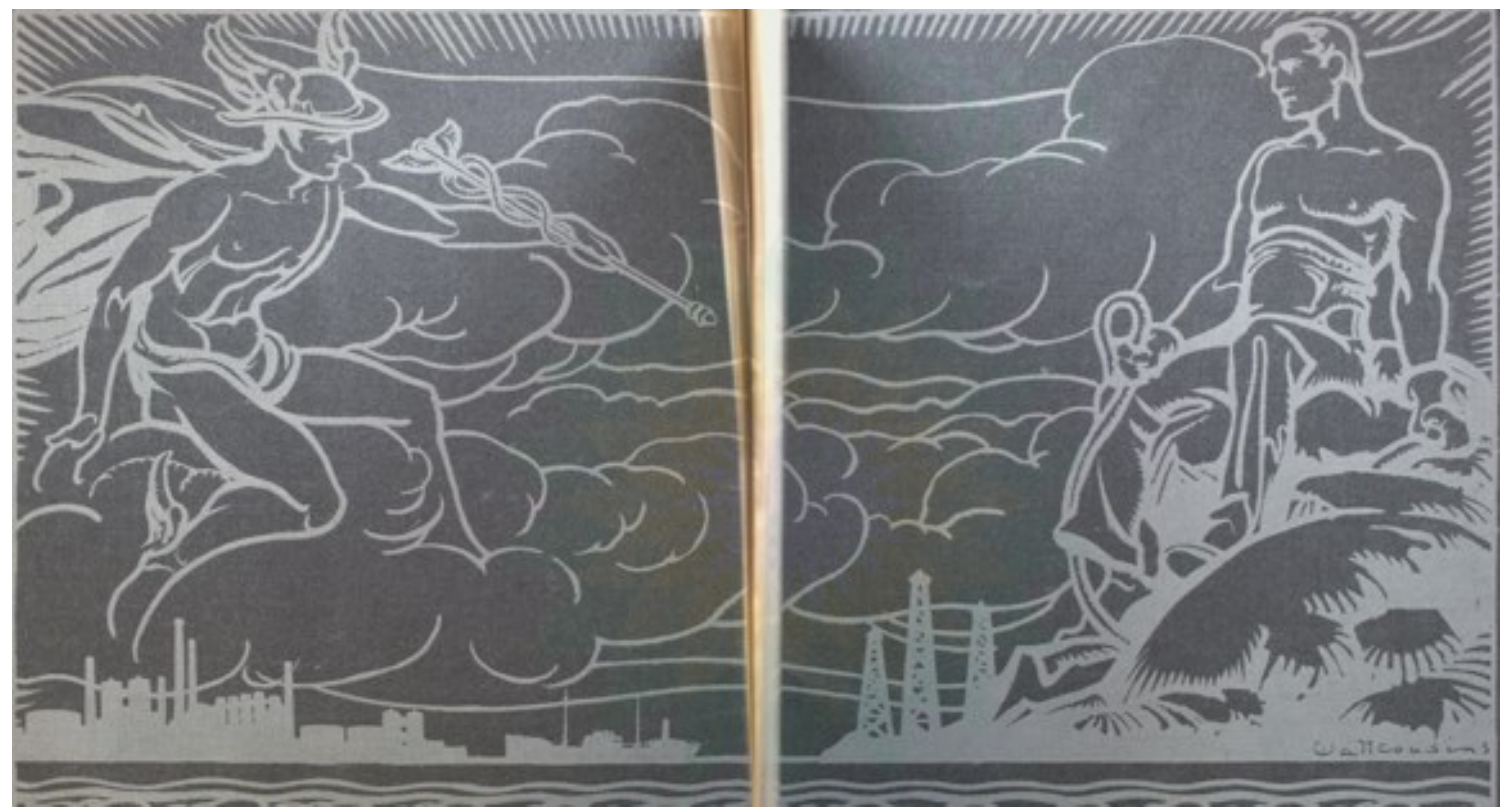

${ }^{459}$ The trope of an "unchained Prometheus" was commonly used during the twentieth century. In 1923, Robert Bruere wrote in "Our Chained Prometheus" that Britons were in the preliminary stages of a "technical revolution" that would "transform the technical structure of our contemporary civilization, and radically alter our habits and modes of life." (R. Bruere, "Our Chained Prometheus: The Coal Problem and its Solution," Harper's Monthly Magazine 147, no. 881 (October 1923): 609). Similar references to oil and Prometheus were exhibited in Paul Manship's sculpture, Prometheus, placed in front of the Rockefeller Centre in New York City in 1934. See also P. Shelley, Prometheus Unbound (London: C. Ollier, 1820); E. Greenwood, Prometheus, U.S.A. (New York: Harper, 1929), and D. Landes, The Unbound Prometheus: Technological Change and Industrial Development in Western Europe from 1750 to Present (Cambridge: Cambridge University Press, 1969). 
Anglo-Persian Oil Company, Llandarcy: England's New Industry, 1922.

In the weeks and months that followed the grand opening ceremony, APOC engaged in a second major campaign to promote the Llandarcy Refinery: the publishing of press advertisements in British newspapers and magazines. ${ }^{460}$ Beginning in the summer of 1922, APOC began to run advertisements in periodicals such as Graphic, the Illustrated London News, the Manchester Guardian, Sketch, Sphere, and The Times featured images and illustrations of the architectural components of the Llandarcy Refinery. An early example of such advertisements was published in Modern Transport magazine in July 1922, a few weeks after the grand opening ceremony. [Figure 7]. Entitled "Where 'BP' Motor Spirit is Made," the full-page advertisement showcased the Llandarcy Refinery as a marvel of modern science and technology. ${ }^{461}$ The background was filled by a detailed drawing of the facility and its associated oil infrastructures, which presented a complex scene of fracturing benches, smoke stacks, workshops, storage tanks, pipelines, and rail lines. Notable inclusions in the illustration were several rail distribution cars and a Thermos Flask fireless engine. The foreground of the advertisement was taken up by a photograph of a man, positioned in front of the refinery illustration. He wore coveralls and a broad smile, and held a 2-gallon can of BP motor spirit out to the viewer in a gesture of offering. ${ }^{462}$ A kind, helpful, and familiar figure, he

\footnotetext{
${ }^{460}$ APOC's advertisements for the Llandarcy Refinery were carried out through its subsidiary company, British Petroleum, which had been marketing and distributing APOC's refined oil products in Britain since 1915. For a discussion of BP advertising during this period, see Chapter Four.

461 "Where 'BP' Motor Spirit is Made," Modern Transport, 19 July 1922; Sketch, 19 July 1922; Illustrated London News, 26 August 1922, 339; Illustrated London News, 9 September 1922, 409.

${ }^{462}$ The same attendant appears in several BP print advertisements published during 1922-1924, in which the figure is represented in a variety of garage scenes. For analysis of these and other advertisements, see Chapter 4.
} 
performed the role of the "BP Man" (akin to the Michelin Man or the Maytag Repair Man). The text of the advertisement informed readers that APOC's "great new refinery" marked the "highest development of modern refining practice," and produced for the British motorist the "finest and most uniform spirit." 
Figure 7: "Where 'BP' Motor Spirit is Made"

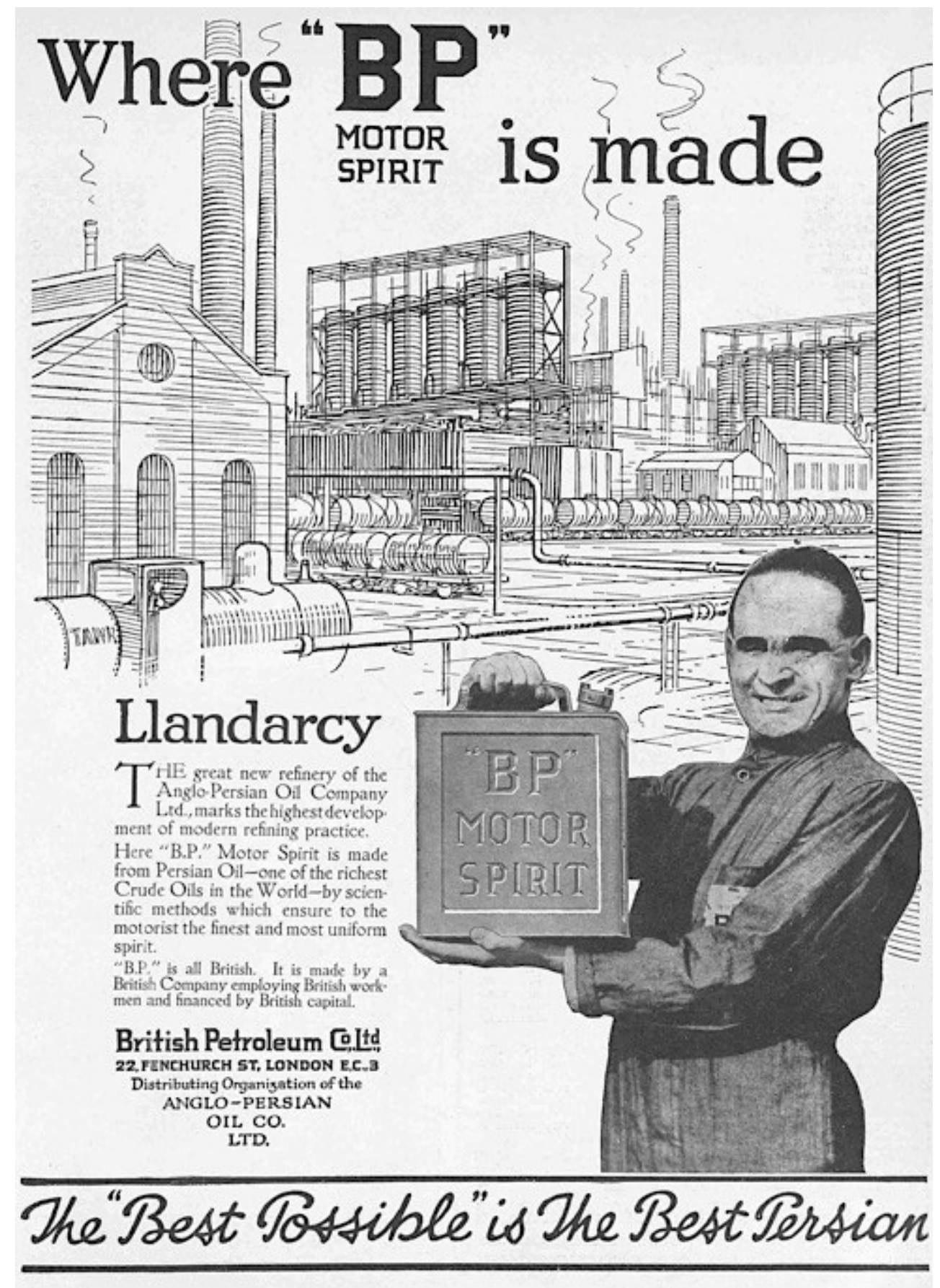

Modern Transport, 19 July 1922. 
APOC published several other advertisements for the Llandarcy Refinery during the summer driving season of 1923. The largest press campaign featured a series of eight advertisements, each of which focussed on a different component of the refinery complex. ${ }^{463}$ Here again, images and stories about oil architecture were pervasive. "Three Years of Work-Three Millions of Money," for example, included an illustration of the Llandarcy Refinery from a distant vantage point, but with the water tower, tank farm, and Crumlyn Bog clearly visible. ${ }^{464}$ "No expense has been spared," the text boasted, and "no resource of chemical and industrial science has been neglected to make this refinery the most efficient in existence. It represents the newest and highest development of refining practice." A drawing of the smiling BP Man holding a 2-gallon BP motor spirit can occupied the bottom-left corner of the advertisement. "A Refinery at Your Door" offered readers a close-up view of the facility's fracturing benches and distillation stacks, as well as a Thermos Flask engine pulling a line of rail cars. A tall, circular storage tank occupied far right of the image, next to which a man was shown turning a valve connected to a series of oil pipelines. The text of this advertisement boldly proclaimed that the Llandarcy Refinery provided the "sort of motor spirit you want, as you want it, and when you want it, manufactured in Britain in one of the world's newest and best refineries." 465

\footnotetext{
${ }^{463}$ The series included four advertisements: "Three Years of Work - Three Millions of Money;" "A Refinery at Your Door;" "75,000,000 Gallons;" "The Floating Pipe-Line;" "1,000 Tests A Day;" "En Route to You;" "The 'BP' Tank Wagon," and "On To You." The advertisements were published in the Belfast News-Letter; Bystander; Graphic; Hartlepool Northern Daily Mail; Hull Daily Mail; Illustrated Sporting and Dramatic News; Lincolnshire Echo; Leeds Mercury; Northern Whig; Portsmouth Evening News; Sheffield Independent; Sketch; Sphere; Sunday Times; Sunderland Daily Echo; Tatler; Western Daily Press; Western Morning News; Yorkshire Evening Post; Yorkshire Post and Leeds Intelligencer.

464 “Three Years of Work - Three Millions of Money," Pall Mall Gazette, 18 January 1923, 7; Sheffield Daily Telegraph, 8 June 1923, 3; Leeds Mercury, 11 July 1923, 10.

465 “A Refinery at Your Door,” Tatler, 15 November 1922, 53; Bystander, 22 November 1922, 91; Birmingham Daily Gazette, 29 November 1922, 10; Illustrated London News, 16 December 1922, 1018.
} 
Other advertisements in this series used oil architecture to tell stories about the complicated process by which oil was delivered from Persia to the consumer. "The Floating Pipe-Line is an apt description of the great fleet of tankers...[that] carry the crude oil from the famous Persian wells to Llandarcy," claimed one advertisement, accompanied by an illustration depicting a vessel unloading its cargo at the Queen's Docks. ${ }^{466}$ The ships used by APOC and the BTC were of the "highest development in the maritime transportation of oil," readers learned, ensuring them a supply of spirit that was "as pure as it flows from the stills." Once at Llandarcy, Persian crude oil underwent “1,000 Tests a Day," it was reported in an advertisement published in October 1922, ensuring quality at "every stage in the progress of the oil through the refinery."467 APOC's petroleum scientists and technologists working at Llandarcy were imagined as "sentinels protecting the interests of the British motorist." The illustration accompanying "En Route to You" pictures a first-person view of the rail yards in which refined oil products were loaded into tank cars for distribution to "every part of the Kingdom." The rolling stock (branded with the letters BP) represented the "first stage of the journey of the finished 'BP' Motor Spirit to your car," the ad explained, and the starting point of the "immense organization" that was required to deliver a product that was "clean, uniform and of the finest quality." 468

The most compelling stories communicated in APOC's print advertising campaign of the early 1920s were those that framed the Llandarcy Refinery as a symbol

466 "The Floating Pipe-Line," Tatler, 7 February 1923, 56; Illustrated London News, 3 March 1923, 358; Illustrated Sporting and Dramatic News, 3 March 1923, 30; Leeds Mercury, 7 March 1923, 11. 467 “1,000 Tests a Day,” Leeds Mercury, 18 October 1922, 10; Tatler, 25 October 1922, 50; Hartlepool Northern Daily Mail, 18 May 1923, 7; Illustrated Sporting and Dramatic News, 24 March 1923, 55. 468 "En Route to You," Tatler, 28 February 1923, 48; Sphere, 3 March 1923, 40; The Times, 2 March 1923, 6; Pall Mall Gazette, 8 March 1923, 10; Graphic, 10 March 1923, 11. 
of the modern age of oil. According to an advertisement entitled, "Where 'BP' Motor Spirit is Made," APOC's new facility marked "the highest development of modern refining practice," while the text of "Britain's New Industry" asserted that Llandarcy was, simply, "the best possible refinery." ${ }^{469}$ The Llandarcy Refinery ranked among "the largest and most modern in the world," bragged an advertisement published in The Times in July 1926, which featured a single word printed in large, bold letters - "Modern."

\section{APOC Oil Architecture and the Construction of British Petroculture}

An effective metric by which to assess the impact that the Llandarcy Refinery had on British oil discourses can be found in contemporary newspapers and magazines. The construction of the refinery generated significant attention in the local Welsh press during the late 1910 s, and in the early 1920s, but Llandarcy and the oil products it manufactured were also the focus of sustained interest across the United Kingdom. In news briefs, short articles, and feature length stories, journalists shared information about the Llandarcy Refinery and the British oil industry with different audiences, often with the aid of illustrations and photographs. It was in this reportage that the fruits of APOC's early promotional activities related to the plant come into full view. Much of the contemporary reporting on the Llandarcy Refinery was couched in the "company language," and the facility was represented using images and stories that were strikingly similar to those present in APOC's press advertisements and souvenir booklet. British newspapers and magazines acted as loudspeakers for the transmission of ideas about the refinery, and thus

\footnotetext{
469 "Where 'BP' Motor Spirit is Made," The Times, 1 December 1922, 6; The Times, 5 January 1923, 6; “Britain's New Industry,” Illustrated Sporting and Dramatic News, 21 October 1922, 208.

470 “B.P.," The Times, 29 July 1925, 5; “Modern," The Times, 16 July 1926, 17.
} 
they were essential components of APOC's larger promotional campaign of the early 1920s. The Llandarcy Refinery was reported to be scientifically and technologically advanced, transformative in its impact on local and national life, and, first and foremost, an architectural symbol of the modern age of oil.

The earliest reporting on the Llandarcy Refinery occurred in 1913, when the facility was in the early phases of conception, and there was scattered coverage of the construction work undertaken at the end of the First World War in papers such as the Gloucester Citizen and the Sunday Times. ${ }^{471}$ During the post-war years, the accelerated pace of construction on the refinery encouraged more frequent reporting. The Illustrated Sporting and Dramatic News, the Saturday Review of Politics, Literature, Science and Art, and The Times covered all the major phases of the build, and the Sunday Times featured updates in its "City Chatter" column. ${ }^{472}$ In the spring of 1921 , The Engineer published several articles on the refinery, eagerly speculating about its cost and schedule for completion. ${ }^{473}$

The grand opening ceremony of the Llandarcy Refinery in 1922 garnered significant attention in dozens of local, regional, and national newspapers in Britain. The event was particularly well covered in the local South Wales press. ${ }^{474}$ Stories were published in practically every newspaper and news journal in the region, including the

\footnotetext{
${ }^{471}$ Gloucester Citizen, 15 January 1913, 5; “Anglo-Persian Oil Co.,” Sunday Times, 14 January 1917, 2. 472 "The City," Saturday Review of Politics, Literature, Science and Art 131 (2 April 1921): 290-291; R. Barrett, "City Chatter," Sunday Times, 13 November 1921, 2; "Refining Motor Spirit in Scotland," Illustrated Sporting and Dramatic News, 13 December 1921, 732; "Oil Power," The Times, 9 November $1921,8$.

473 "Llandarcy Oil Plant," The Engineer, 1 April 1921, 345; “A Seven-Day Journal,” The Engineer, 1 April $1921,345$.

${ }^{474}$ Although celebrated in Swansea, the Llandarcy Refinery was resented by many in South Wales's ailing coalmining industry. According to a Communist Party pamphlet published in 1921, the "52 oil tanks at Skewen" represented "a blow between the eyes to the South Wales miner." J. Newbold, The Doom of a Coalfield: 'Big Business' in South Wales (London: Communist Party of Great Britain, 1921): 7.
} 
South Wales Daily Post; the South Wales Echo; the South Wales Evening Express; the South Wales Journal; the South Wales Journal of Commerce; and the South Wales News. ${ }^{475}$ The Western Mail, the region's largest daily newspaper, covered the ceremony in lengthy articles published in late June. The paper prophesized that the "unprecedented scale" of the event would "stand in the history of industrial development in this country as marking a distinct departure" from the ways of the past. ${ }^{476}$ In an article published on 30 June, a journalist who had participated in the guided tour of the Llandarcy Refinery noted that the event had been particularly helpful in making sense of the complicated journey taken by crude oil as it moved through the "most elaborate and extensive oil distillation plant in Great Britain." ${ }^{477}$ It was reported that the party of journalists had left feeling "of one mind," fully appreciative of the "revolution...taking place in oil manufacture." ${ }^{478}$ The paper delighted in the "souvenir brochure" that was provided for the ride home and suggested that it be used as a guide for future reference, noting that it explained "in graphic detail the magnitude of the undertaking" at Llandarcy. ${ }^{479}$

The themes of transition, transformation, and modernity dominated the narratives used to describe the refinery. The South Wales Evening Express wrote optimistically about the facility's impact on the "Future of Swansea," and the Cardiff Weekly Mail ran a large, bold headline declaring "Great Works Opened at Llandarcy." ${ }^{80}$ On 29 June, the

\footnotetext{
475 "Great Oil Works," South Wales Daily Post, 29 June 1922; South Wales Echo, 29 June 1922; "Future of Swansea," South Wales Evening Express, 29 June 1922; “A Great Enterprise," South Wales Journal, 29 June 1922; "The Great West Wales Undertaking," South Wales Journal of Commerce, 30 June 1922; "The Llandarcy Oil Refinery," South Wales News, 30 June 1922.

476 "Oil Works in Wales," Western Mail, 29 June 1922.

477 “New National Industry. Swansea's Future," Western Mail, 30 June 1922, 3.

478 Western Mail, 30 June 1922, 3.

479 Western Mail, 30 June 1922, 3.

480 "Future of Swansea," South Wales Evening Express, 29 June 1922; "Great Works Opened at Llandarcy," Cardiff Weekly Mail, 1 July 1922.
} 
South Wales Daily Post declared that "the advent of the oil trade to this district is fraught with immense possibilities to the port of Swansea," and in an article published the following day, the paper argued that the new refinery was "one of the finest coups yet accomplished for the furtherance of the idea of "A Greater Swansea." "481 According to the South Wales Journal, APOC had created a "gigantic organization" at Llandarcy, which promised to transform the quaint seaside town of Swansea into one of the "chief oil bunkering centres of the world." ${ }^{\prime 42}$ The Western Mail painted a particularly dramatic image of transition, suggesting that Llandarcy was symbolic of the "forward march of progress" in the realm of British energy consumption: "Oil, the great rival of coal, is now indefinitely installed as one of the principal industries of South Wales." ${ }^{483}$

In the days and weeks that followed the grand opening of the Llandarcy Refinery, reports of the new facility and the oil products that it manufactured began to spread to communities across the United Kingdom. A variety of specialist magazines and journals covered the event, including the Colliery Guardian; the Commercial Motor; the Grocer; Oil News; Petroleum Times; Modern Transport; the Oil \& Colour Trades Journal, and Oil Engineering and Finance. ${ }^{484}$ In London, papers such as the Daily Chronicle, the Daily Mail, the Morning Post, and The Times covered the opening of the refinery, with

\footnotetext{
481 "Great Oil Works," South Wales Daily Post, 29 June 1922; "Brains of the Britisher," South Wales Daily Post, 30 June 1922.

482 “A Great Enterprise,” South Wales Journal, 29 June 1922.

${ }^{483}$ Western Mail, 29 June 1922, 4.

484 "Fuel Oil," Colliery Guardian, 30 June 1922, 1129; "Oil Industry Growth," Commercial Motor, 22 May 1923, 4; "New Oil Refinery in South Wales," Grocer, 1 July 1922; "Formal Opening of the Anglo-Persian Refinery," Oil News, 1 July 1922; "The Anglo-Persian Company's New Refinery," Petroleum Times, 1 July 1922; "Oil-Refining in Great Britain," Modern Transport, 1 July 1922, 3, 5; "Oil Refining in S. Wales," Oil \& Colour Trades Journal, 1 July 1922; “The Anglo-Persian Oil Co. Limited,” Oil Engineering and Finance, 1 July 1922, 817-820.
} 
headlines declaring “A Great Enterprise” and a "New British Industry." 485 Significant attention was drawn to Llandarcy in the newspapers of the heavily industrialised (and coal-producing) Midlands. The Birmingham Post envisioned a "New Oil Industry for the Country," while the Manchester Guardian heralded "A New Departure” in Britain's energy future. ${ }^{486}$ Equally enthusiastic reports about Llandarcy were published in the Sheffield Daily Telegraph, the Yorkshire Observer, and the Yorkshire Post. ${ }^{487}$ In Edinburgh, a city at the heart of the shale oil industry, readers of the Scotsman learned of the "Great Oil Refinery at Swansea," and its potential to revolutionize the oil industry in other parts of the United Kingdom. ${ }^{488}$

Local newspapers covered the completion of the Llandarcy Refinery, usually in short news briefs consisting of a few sentences. The Bath Chronicle and the Daily Sketch, for example, cited the large gathering of distinguished guests who had visited the refinery during the grand opening ceremony, and the Daily News reported that APOC's "Up-toDate Plant" was ready to scale up its manufacturing operations. ${ }^{489}$ News briefs related to Llandarcy were also published in the Aberdeen Press and Journal, the Buckingham Advertiser, the Hartlepool Northern Daily Mail, the Wells Journal, and the Western Daily Press. $^{490}$

485 "Model Village and Works on Bristol Channel," Daily Chronicle, 30 June 1922; "New British Industry," Daily Mail, 30 June 1922; “A Great Enterprise," Morning Post, 30 June 1922; "Oil Refining at Swansea," The Times, 30 June 1922.

486 "New Oil Industry for the Country," Birmingham Post, 30 June 1922; Liverpool Journal of Commerce, 29 June 1922; “A New Departure," Manchester Guardian, 30 June 1922.

${ }^{487}$ Sheffield Daily Telegraph, 30 June 1922, 8; “A New Industry,” Yorkshire Observer, 30 June 1922;

Yorkshire Post, 13 June 1922, 5; "New British Industry," Yorkshire Post, 30 June 1922.

488 "Great Oil Refinery at Swansea," Scotsman, 30 June 1922, 5.

489 "Model Village and Works on Bristol Channel," Bath Chronicle, 30 June 1922; "Up-To-Date Plant," Daily News, 30 June 1922; “25,000,000 Gallon Oil Store,” Daily Sketch, 30 June 1922.

${ }^{490}$ Aberdeen Press and Journal, 12 June 1922, 3; “A New British Industry," Buckingham Advertiser and Free Press, 8 July 1922, 6; Hartlepool Northern Daily Mail, 12 June 1922, 5; Wells Journal, 11 August 1922, 2; "British Petroleum," Western Daily Press, 10 November 1922, 3. 
As they had in APOC's promotional activities during the period, visual aids such as drawings, maps, and photographs were central to the press reportage connected to the Llandarcy Refinery. In expensive newspapers such as Lloyd's List, the Illustrated London News, Tatler, Graphic, and Sphere, but also in smaller newspapers such as the Hull Daily Mail and the South Wales Daily Post, readers learned about APOC's new refining facility through rich, image-laden articles. ${ }^{491}$ The principal subject of these images was Llandarcy's modern oil architecture. On 1 July 1922, the Petroleum Times published a special "Full Report" on the refinery, accompanied by eight "exclusive photographs" and an illustrated map. ${ }^{492}$ According the author of the article, Llandarcy had been constructed using "all the latest improvements" in science and technology, which meant that the facility operated "without the slightest hitch." As a result of the company's "mammoth energy," it was reported, APOC had erected a refinery that "in layout, efficiency, and economy of operation takes second place to no plant of its kind in the world."

Several other illustrated feature articles were published in British newspapers and magazines on 1 July 1922. Modern Transport published a full-page story entitled "Oil Refining in Great Britain," which included a panoramic illustrated map of the refinery grounds, as well as a collection of black and white photographs of different oil buildings and infrastructures - a tanker unloading its cargo at the Queen's Dock; oil pipelines delivering crude to the refinery; rail tank cars being filled with product; and Llandarcy's

\footnotetext{
491 "Persian Oil for the British Navy," Illustrated London News, 27 June 1914, 11; "British Petroleum," Illustrated London News, 3 November 1923, 29; "A Great New Enterprise," Lloyd's List, 30 June 1922; "B.P. Spirit," Tatler, 7 November 1923, 92; "Llandarcy," Graphic, 16 September 1922, 37; "Oil for the Navy," Sphere, 25 July 1914, 16; "B.P. Petrol," Hull Daily Mail, 27 November 1923, 4; Anglo-Persian Oil Works Opening on Thursday," South Wales Daily Post, 28 June 1922. 6.

492 “The Anglo-Persian Company's New Refinery,” Petroleum Times, 1 July 1922.

493 “The Anglo-Persian Company’s New Refinery," Petroleum Times, 1 July 1922.
} 
fire brigade assembled in front of the central water tower. ${ }^{494}$ Oil Engineering and Finance printed a different series of photographs in its special feature on the "AngloPersian Oil Co.," including Llandarcy's power generating stations, electrical pump houses, laboratories, and storage facilities, as well as a series of oil pipelines. ${ }^{495}$ These illustrated articles helped readers to imagine the Llandarcy Refinery and the products it made, while at the same time provided a compendium of images with which to think about oil and its broader implications for Britain. A scan of the collection of historical photographic materials held at the BP Archives reveals that the vast majority of images presented in the contemporary British newspaper and magazine coverage of the Llandarcy Refinery were produced by APOC. ${ }^{496}$

While the company may have provided some of the images that appeared in the British press coverage of the Llandarcy Refinery, it likely had little control over the narratives that were crafted to describe the facility. Thus, it is in the stories told about Llandarcy in British newspapers and magazines that the energy historian can glean valuable insight into the impact of APOC's promotional activities on the construction of British petroculture during the early 1920s. With this in mind, it is instructive that one of the most commonly used words to describe the Llandarcy Refinery during the period was "great" - a "Great New Enterprise" (Lloyd's List); and "The Great Oil Works" (South

\footnotetext{
494 "Oil-Refining in Great Britain," Modern Transport, 1 July 1922, 3, 5. The article also included a photographic portrait of APOC Chairman, Sir Charles Greenway.

495 “The Anglo-Persian Oil Co. Limited," Oil Engineering and Finance, 1 July 1922, 817-820. The article also includes a list of APOC oil tankers and their respective tonnages.

${ }^{496}$ See Anglo-Persian Oil Company, A Selection of Photographs Depicting the Operations of the AngloPersian Oil Company in Persia and South Wales, 1920-1926. BP Archives, ARC36529; Collection of Back and White Negatives, [c. 1922]. ARC 209175; A British Oil Industry: Processes in the Oil Industry from the Crude Oil to be Finished Motor Spirit, Stereoscopic Views of the Oil Refinery in South Wales (Llandarcy) and Distribution Centre in London, 1924. ARC 29341; Llandarcy Refinery, 1948. ARC 127642.
} 
Wales Daily Post); "The Great West Wales Undertaking” (South Wales Journal of

Commerce). ${ }^{497}$ According to the Exeter and Plymouth Gazette, Llandarcy represented

"Britain's Triumph" in the international oil industry, a phrase that invoked the

nationalism reminiscent of sporting events or wars. ${ }^{498}$

Llandarcy was framed as a symbol of the modern science and technology of oil.

In its report on APOC's new Welsh refinery, the Statist magazine commended the widespread use of "modern sanitary science," while Chemistry and Industry informed its readers that the refinery was "equipped with the most modern plant." ${ }^{\text {"499 }}$ The Financier reported on 3 July 1922 that APOC had built "a complete modern refinery" at Llandarcy, finally bringing together "all stages of [oil's] progress from the production of crude at the wells to delivery of the refined products to the consumer." ${ }^{500}$ The Western Mail concluded in its assessment of Llandarcy that "[i]n perfection of lay-out, in efficiency and economy of operation, the refinery is the last word in scientific construction." 501

Connected to these teleological and millenarian stories of industrial progress at Llandarcy were narratives of transition and transformation. According to the author of an article published in Modern Transport, APOC had converted "a waste of rabbit warren and low-lying bogland" into one of the most advanced oil refineries in the world, while an article published in the Petroleum Times marvelled at the thought of Britain's first oil

\footnotetext{
497 “A Great New Enterprise," Lloyd's List, 30 June 1922; "Great Oil Works," South Wales Daily Post, 29 June 1922; "The Great West Wales Undertaking," South Wales Journal of Commerce, 30 June 1922. For additional examples, see "A Great Enterprise," South Wales Journal, 29 June 1922; "Great Oil Refinery at Swansea," Scotsman, 30 June 1922, 5; “A Great Enterprise," Morning Post, 30 June 1922; "Great Works Opened at Llandarcy," Cardiff Weekly Mail, 1 July 1922.

498 "Britain's Triumph," Exeter and Plymouth Gazette, 1 September 1922, 11; "Britain's Oil Triumph," Northern Whig, 1 September 1922, 9.

499 "New Anglo-Persian Refinery," Statist, 1 July 1922; "The Llandarcy Refinery of the Anglo-Persian Oil Company," Chemistry and Industry, 18 May 1923, 482-483.

500 "Oil Topics," Financier, 3 July 1922.

${ }^{501}$ Western Mail, 29 June 1922, 4.
} 
refinery being built in a swamp. ${ }^{502}$ Lloyd's List declared the grand opening of the Llandarcy Refinery "Swansea's Red-Letter Day,” and suggested to its readers that the event portended "a new and vastly important stage in its career...Swansea's prospects for the future should be very bright." ${ }^{.503}$ Other newspapers conjured up imaginative and thought-provoking scenes of energy in transition to describe Llandarcy. The Yorkshire Post highlighted the clash of architectural styles present at the refinery and encouraged its readers to consider the juxtaposition of the "wild Welsh hills" and the "closely organised series of structures linked together by pipes, visible and invisible." ${ }^{504}$ The creativity of the Manchester Guardian was also stirred by the contradictions between the traditional and the modern at Llandarcy. In an article published by a journalist who had participated in the grand opening tour of the refinery, the author recalled standing at the centre of the complex, surrounded by a cacophony of pipes, tanks, towers, and laboratories. "One small cottage stands at a little distance," the journalist explained, "abashed it seems, and almost overpowered by this wealth of energy poured by strange Persia into the engines of the civilised machine. ${ }^{.505}$

For several British newspapers, the transformations brought about by APOC's Llandarcy Refinery portended a new energy regime, that would be increasingly defined

502 "Oil Refining in Great Britain,” Modern Transport, 1 July 1922, 3; “The Anglo-Persian Company's New Refinery," Petroleum Times, 1 July 1922, 7. Similar language was used to describe APOC's Abadan Refinery in Persia. An article published in the Illustrated London News in 1951 reported on the transformation of "desolate and mountainous" Persian landscapes into "the world's greatest refinery." Illustrated London News, 31 March 1951, 490-491. 503 "Swansea's Red-Letter Day," Lloyd's List, 29 June 1922.

504 "New British Industry," Yorkshire Post, 30 June 1922.

505 “A New Departure," Manchester Guardian, 30 June 1922. APOC invoked a similar feeling in a 1937 pamphlet about Llandarcy, which argued that "anyone visiting the locality today who was familiar with the landscape before the Refinery was projected would have the greatest difficulty in associating [it] with the green fields and copses of the past." Anglo-Iranian Oil Company, Llandarcy: A Survey (London: The Company, 1937): 1. 
by the consumption of refined oil products. References to oil bringing about an historical new energy age, era, or epoch could be found in publications as different as the South Wales Daily Post, the Yorkshire Observer, and the Financial Times. ${ }^{506}$ According to Dublin's largest daily newspaper, the Northern Whig, the completion of the refinery marked "an innovation of the highest moment" in the British oil industry, while the Dundee Courier imagined APOC's facility as "a milestone in the progress of the oil industry" writ large. ${ }^{507}$ The Sheffield Daily Telegraph went one step further, and proclaimed that the Llandarcy Refinery represented not only a sea change in the British oil industry, but also the opening of a new "epoch in the industrial history of the country. ${ }^{" 508}$ The Liverpool Journal of Commerce captured this transitional moment in a prescient observation on the shifting tides of energy in South Wales, Britain, and beyond. "There is a touch of irony in the fact that the seat of the enterprise lies on the fringe of the world's greatest coalfield," the paper mused in an article published on the day of the grand opening ceremony of the Llandarcy Refinery, "and it serves as a reminder that oil and not coal is probably destined to be the common fuel in future years." ${ }^{\prime 509}$

The Llandarcy Refinery was continually expanded upon during the remainder of the interwar period. It reached peak capacity in 1967, producing eight million tonnes per year, and it remained the largest facility of its kind in Britain until the mid-1970s. ${ }^{510}$ In 1985 , components of the refinery were converted to produce lubricating oils and waxes

\footnotetext{
506“"Great Oil Works," South Wales Daily Post, 29 June 1922; “A New Industry,” Yorkshire Observer, 30 June 1922; "The Newest British Industry," Financial Times, 4 July 1922.

507“New Oil Refinery to be Opened. Innovation at Swansea," Northern Whig, 12 June 1922, 6; "Milestones in British Oil Industry," Dundee Courier, 13 June 1922, 2.

${ }^{508}$ Sheffield Daily Telegraph, 30 June 1922, 8.

${ }^{509}$ Liverpool Journal of Commerce, 29 June 1922.

510 "BP Plays a Big Part in British Progress," Sunday Times, 22 October 1950, 1; Welsh Economic Plan, Wales: The Way Ahead (Cardiff: HMSO, 1967); T. Stradling, The National Oil Refineries, Ltd. Llandarcy (Swansea: The Author, 2005): 2; "BP Signals Exit from UK Refining," Oil Daily, 27 June 2006, 1.
} 
for heavy machinery, bitumen for road construction, and charcoal briquettes destined for British barbeques. ${ }^{511}$ After several rounds of layoffs during the late 1980s and early 1990s, the facility shut its doors in the spring of $1998 .{ }^{512}$ Recently, Llandarcy has undergone a new phase of modern transformation. In a multi-phase project spearheaded by the Prince's Foundation, the heavily-polluted grounds of the former refinery are being converted into a massive planned village of 4,000 residences. ${ }^{513}$ The community is named Coed Darcy in honour of the British oil patriarch, William Knox D'Arcy, and has been described as being built on "boggy woodland and waste ground." 514 According to former APOC employee, and long-time resident of Llandarcy, Vivian Griffiths, "the Coed Darcy regeneration scheme is once again breathing life into the area" ninety years after APOC's refinery was completed. "It's exciting to see Llandarcy become a significant development once again in South Wales." ${ }^{515}$

Conclusion: Imagining Llandarcy and the Age of Oil

${ }^{511}$ British Petroleum, BP Oil, Llandarcy Refinery Limited (London: the Company, 1993 ): 2.

512 File of Press Cuttings and Journal Articles Associated with BP Operations at Llandarcy Refinery, 19801985. BP Archives, ARC 144116; "Oil Jobs hit by a Slump," Sunday Times, 13 April 1985, 57; I. Barney, "The Economic and Social Consequences of the Closure of BP Llandarcy," Contemporary Wales 13 (2000): 138-158.

513 British Petroleum, LLandarcy Urban Village: Masterplan Launch, VHS, 7:22 minutes, 2003. ARC 194824. On the pollution left by the Llandarcy Refinery, see Royal Commission on Environmental Pollution. Eighth Report: Oil Pollution of the Sea, 1981. Cmd. 8358. BP presented its own narrative of the pollution left at Llandarcy in a series of illustrated pamphlets, entitled BP Oil Llandarcy Refinery Limited (London: The Company, 1994); Llandarcy, Products, Customers and Product Uses (London: The Company, 1994); Good Neighbours: 75 Years of Refining, 1921 to 1996 (London: The Company, 1996); Environmental Issues (London: The Company, 1996).

514 The budget for the project is $£ 1.2$ billion. See Prince’s Foundation: Coed Darcy Village Restoration, 2018. Retrieved from: www.princes-foundation.org/building-places-architecture-uk/141-coed-darcyarchitecture; "The Village Green Preservations Society," Wales Online, 15 November 2004. Retrieved from: www.walesonline.co.uk/news/wales-news/village-green-preservation-society-2415474.

${ }^{515}$ R. Turner, "Looking Ahead to a New Village Skyline, As Last of the Llandarcy Refinery Comes Down," Wales Online, 2 October 2009. See also V. Griffiths, "A Look Back and a Glimpse of the Future," DVD, 56:00 minutes, 2015. 
This chapter has examined the early history of oil in Britain using the Llandarcy Refinery and its representation in APOC promotional activities as a case study. Completed in 1921, the refinery was Britain's first and, for some time, largest oil refinery. It utilised the most advanced science and technology, provided employment for thousands of workers, and supplied one third of the domestic motor spirit market. The creation of the facility was a defining moment in the story of oil in Britain, which marked the beginning of a new direction in the country's energy trajectory. Most importantly for this study, the refinery was an integral component of British oil imaginaries during the early 1920 s and a symbol of the modern age of oil.

Despite this historical significance, Llandarcy has been overlooked in the historiographical literature. There are very few serious investigations into the refinery's past, and no study has yet taken into account the role that APOC promotional activities played in the distribution of images, stories, and ideas about the facility among British audiences. Energy historians, in particular, have neglected to assess APOC's publicity connected to the Llandarcy Refinery as a crucial component of the promotion of Britain's transition to oil.

This chapter has worked to fill the silence in scholarly understandings of the early history of the Llandarcy Refinery. Using oil architecture as an analytical framework and APOC promotional activities as a central body of primary source evidence, the chapter has shown the significant contributions that APOC made to the tapestry of early British petroculture during the company's formative years. In tracing the ways in which APOC communicated information about the facility to targeted British audiences, including the hosting of private guided tours and the publication of press advertisements and souvenir 
booklets, this research has sought to shed light on the company's vision of oil as a modern resource produced in scientifically and technologically advanced refineries like Llandarcy. What images, stories, and ideas about oil were conveyed in APOC's promotional activities, and how were they informed by larger British conversations about oil? In answering this question, it has been revealed that APOC must be understood not only as an oil company that sold goods, but as a conduit for the transmission of knowledge about oil, and an important player and stakeholder in the making of British petroculture during the early 1920s. As APOC's promotional activities made clear, and as the press reportage connected to the facility later confirmed, the Llandarcy Refinery was much more than a plant where oil was manufactured - it was an edificial symbol of the science and technology that was fuelling the modern age of oil. 
Figure 8: Thermos Flask fireless locomotives at the Llandarcy Refinery

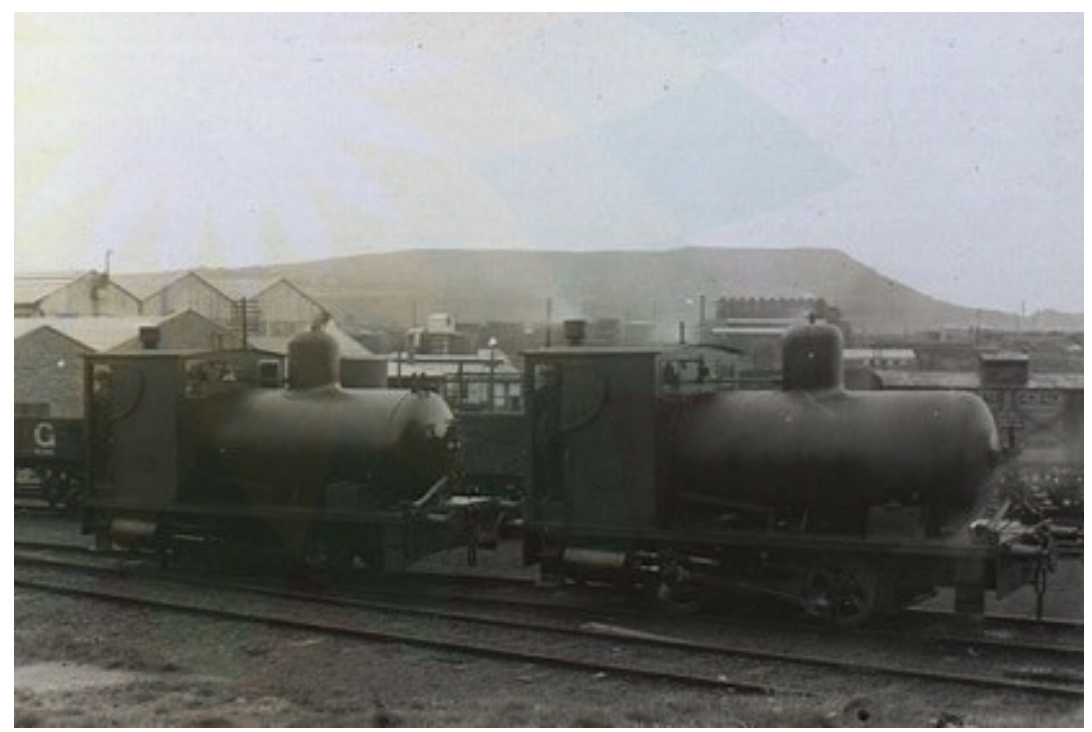

Anglo-Persian Oil Company Photographic Collection, 1926.

Figure 9: Residences for senior management staff, Cefn Park

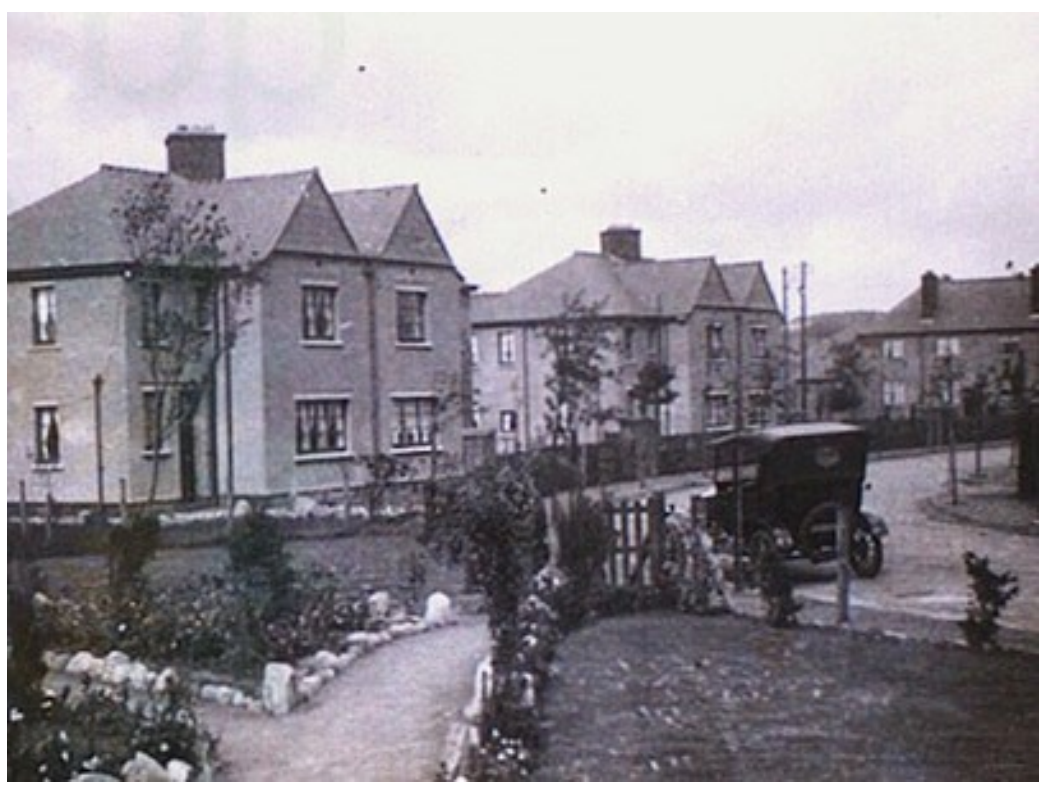

Anglo-Persian Oil Company, A British Oil Industry, $1924 .{ }^{516}$

\footnotetext{
${ }^{516}$ Anglo-Persian Oil Company, A British Oil Industry: Processes in the Oil Industry from the Crude Oil to be Finished Motor Spirit, Stereoscopic Views of the Oil Refinery in South Wales (Llandarcy) and Distribution Centre in London (London: the Company, 1924).
} 
Figure 10: A view of The Greenway, Llandarcy Village

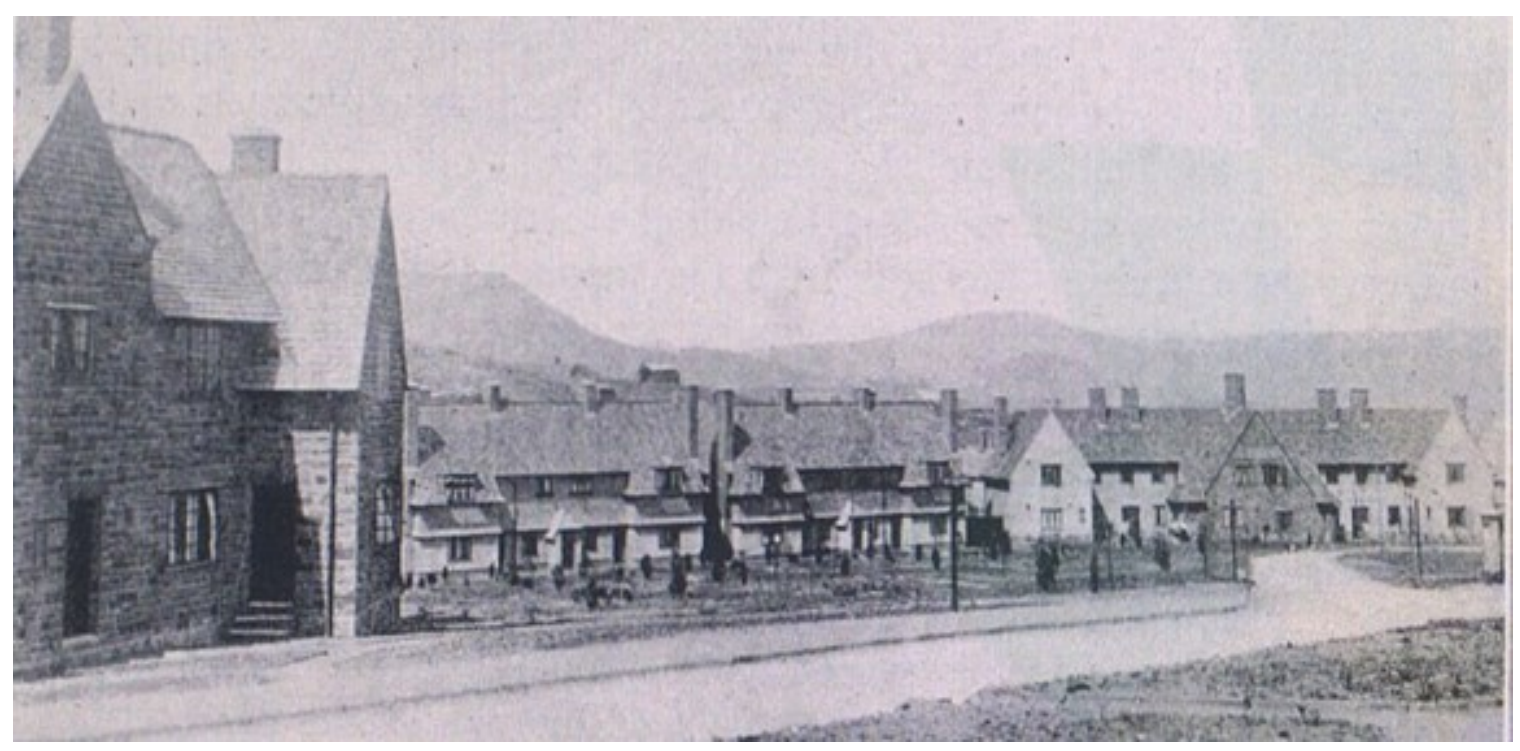

Anglo-Persian Oil Company, Llandarcy: England's New Industry, 1922.

Figure 11: Illustration of Llandarcy Refinery

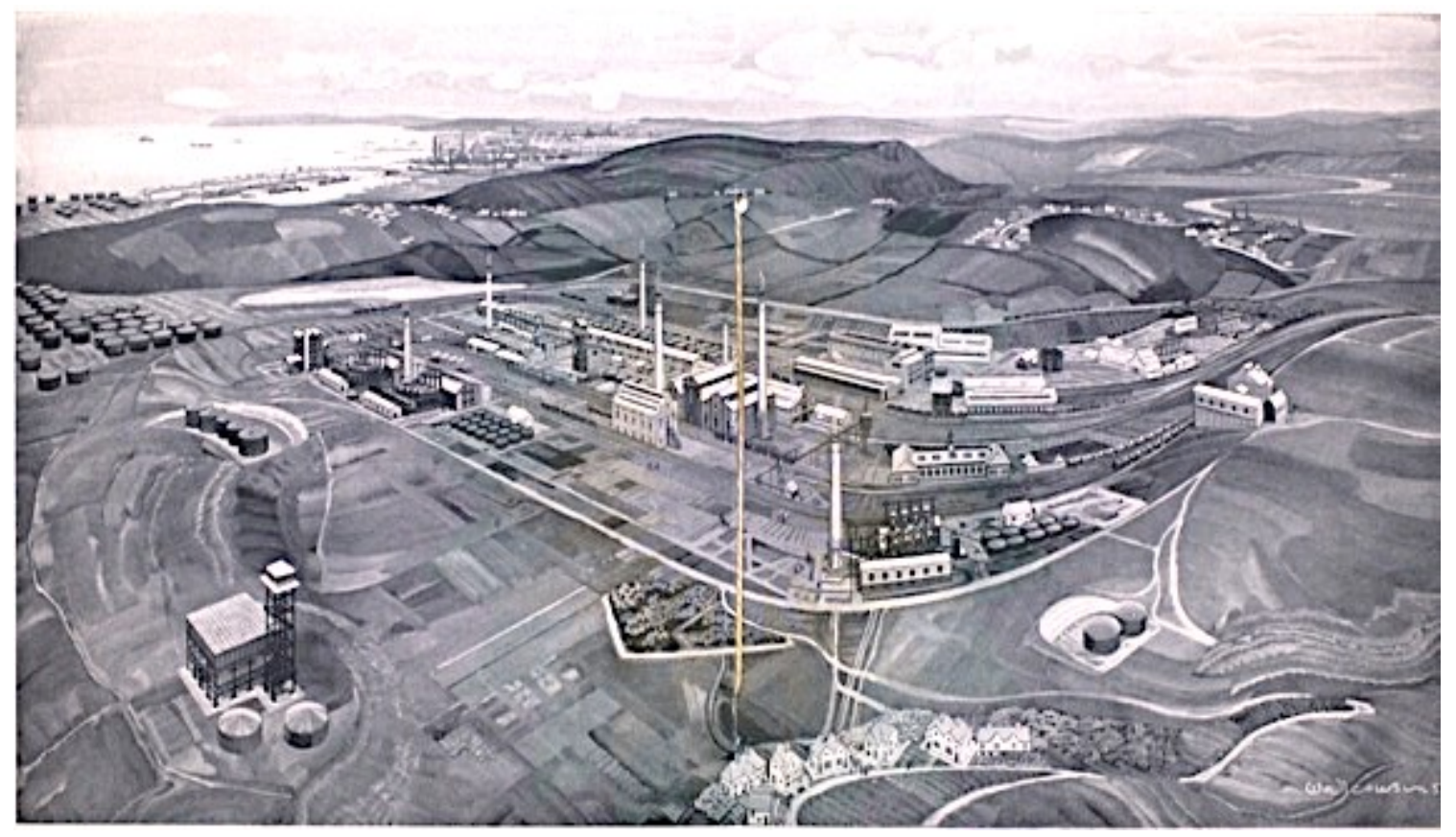

Anglo-Persian Oil Company, Llandarcy: England's New Industry, 1922. 


\section{Chapter Four \\ Selling the Age of Oil: The British Petroleum Company and Motor Spirit Marketing, 1919-1925}

This chapter examines the motor spirit marketing activities of the British Petroleum Company (BP) during the period 1919-1925. ${ }^{517}$ In those years, BP became the marketing and distribution subsidiary of the Anglo-Persian Oil Company (APOC), and expanded to become the third-largest corporate entity of its kind in Britain. ${ }^{518}$ In order to increase its share of the ever-increasing British motor spirit market, BP invested in a variety of advertising campaigns designed to attract the attention of potential customers. Through these promotional efforts the company produced a series of creative images and stories about oil, which encouraged and directed its public audiences to think about the resource, and to imagine it in new ways. This chapter analyzes BP's motor spirit marketing in order to reconstruct the company's vision of oil, and to explore its contribution to the development of British petroculture. Specifically, the chapter traces the evolution of BP's marketing activities from their modest beginnings in the immediate post-war years, when the company had nothing but a few ledger books to show its customers, to the expensive, multi-dimensional publicity campaigns of the mid-1920s, which culminated in the Persian Khan exhibit mounted at the British Empire Exhibition of 1924-1925. By these means, it is argued BP used motor spirit marketing as a powerful

\footnotetext{
${ }^{517}$ BP was formed in June 1906 by a German oil company, and in 1917 it was acquired by the AngloPersian Oil Company (APOC) to serve as a marketing and distribution company responsible for publicizing, advertising, and selling the parent company's Persian oil products in Britain. For a discussion of BP's formation, see R. Ferrier, The History of The British Petroleum Company, Vol. 1, The Developing Years, 1901-1932 (Cambridge: Cambridge University Press, 1982).

${ }^{518}$ BP's chief competitors were the Anglo-American Oil Company (1) and the Shell-Mex Oil Company (2).
} 
instrument for communicating ideas about technology, modernity, and the future of oil in Britain, and a foundational tool in the building of British petroculture.

For the energy historian, BP's early marketing activities contain a densely packed store of data and materials regarding the company's interpretation of oil and, importantly for this chapter, the manners in which the company wanted British consumers to imagine the resource. Activities like erecting outdoor signage, publishing newspaper and magazine advertisements, and participating in public exhibitions offer a clear reflection of the evolution of BP's corporate petroculture, while at the same time affording insights into how the company situated itself within larger British conversations about oil.

Despite their rich value as primary sources, the marketing campaigns of British oil companies have been relatively overlooked by historians. There is a significant body of work on the company's early history and its expanding presence in Britain and around the world, but scant attention paid to BP's marketing activities during its formative years. Histories such as Marian Kent's Oil and Empire (1976) and Geoffrey Jones's The State and the Emergence of the British Oil Industry (1981) feature extensive analysis of the development of BP's management structure and contractual relationships during the 1910s and 1920s, but they contain no references to marketing or advertising. ${ }^{519}$ There is a brief discussion of Shell-Mex marketing activities in Jones's 1978 article, “The Oil Fuel Market in Britain 1900-1914," including the publication of illustrated souvenir booklets, but Jones offers no analysis of the content of these materials. ${ }^{520}$ Daniel Yergin's The Prize (1992) dedicates only a few paragraphs to oil company marketing in the first half of

\footnotetext{
${ }^{519}$ M. Kent, Oil and Empire: British Policy and Mesopotamian Oil, 1900-1920 (London: Macmillan, 1976); G. Jones, The State and the Emergence of the British Oil Industry (London: Macmillan, 1981). ${ }^{520}$ G. Jones, "The Oil-Fuel Market in Britain 1900-1914: A Lost Cause Revisited," Business History 20, no. 2 (1978): 131-152.
} 
the twentieth century, concentrating on American advertising guru, Bruce Barton, and his promotion of the "Magic of Gasoline" in the late-1920s. ${ }^{521}$ In short, historians have focused their attention on BP's acquisition of market share, money, and political power in its early period, paying scarce attention to ways in which the company advertised and sold its oil products.

A handful of scholars have investigated individual aspects of British oil company marketing during the 1910s and 1920s. Donald Dixon has researched the distribution of motor spirits in the United Kingdom during the twentieth century, including the marketing of Shell, Mexican Eagle, and Anglo-American oil companies. ${ }^{522}$ Dixon acknowledges the peculiarities of the British market, in which the private garage "developed as a unique type of marketing agency," but his analysis is confined to the evolution of motor spirit pump design, and entirely overlooks the contributions made by BP. ${ }^{523}$ In his article on the history of British attitudes toward filling up, David Jeremiah explores the evolution of the design of motor spirit pumps and selling stations during the 1920 s. $^{524}$ Jeremiah concludes that these activities offer "visible evidence of the speculative beginnings of a new culture" in Britain, one that was intimately connected to larger conversations about modernity and the future. ${ }^{525}$ However, like Dixon, Jeremiah focusses exclusively on Shell and Anglo-American marketing of the late 1920s and 1930s, with BP's activities noticeably absent.

\footnotetext{
${ }^{521}$ D. Yergin, The Prize: The Epic Quest for Oil, Money and Power (New York: Simon, 1992): 193-194. For an example of Barton's work, see B. Barton, The Man Nobody Knows (Indianapolis: Gosset, 1925).

${ }^{522}$ D. Dixon, "Petrol Distribution in the U.K., 1900-1950," Business History 6, no. 1 (1963): 3.

${ }^{523}$ Dixon, 1963, 7.

${ }^{524}$ D. Jeremiah, "Filling up: The British Experience, 1896-1940," Journal of Design History 8, no. 2 (April 1995): 97-116.

${ }^{525}$ Jeremiah, 1995, 114.
} 
Robert Brown has conducted research on the outdoor advertising campaigns of British oil companies during the interwar period, paying particular attention to the proliferation of roadside signs, billboards, and motor spirit pumps ${ }^{526}$ While Brown does include a brief discussion of BP outdoor marketing in his study, the bulk of his analysis is focussed squarely on Shell-Mex and Anglo-American examples from the early 1930s, as well as examples of outdoor advertising from other European markets. Tim Nicholson's detailed analysis of the form and function of historical British road maps is another notable example of research that targets an individual aspect of British oil company marketing. ${ }^{527}$ While many of these scholars take BP's motor spirit marketing activities into account in their studies, there is a distinct lack of research that incorporates multiple advertising campaigns into a single frame of analysis, like those of BP examined in this chapter.

The marketing activities of foreign oil companies operating in Britain have been the subject of considerable research. Julian Bowden's article on the marketing of Russian Oil Products (ROP) examines the design of the company's motor spirit pumps and its efforts to compete with larger sellers but, unfortunately, he provides no discussion of other promotional activities undertaken by the company. ${ }^{528}$ Advertisements produced by the Shell Transport and Trading Company (and its distribution subsidiary, Shell-Mex), have generated significant scholarly attention. T. Sheppard and J. Hoole have critically examined the artwork featured in Shell's interwar posters and billboards, while John

\footnotetext{
${ }^{526}$ R. Brown, "Cultivating a 'Green' Image: Oil Companies and Outdoor Publicity in Britain and Europe, 1920-1936," Journal of European Economic History 22, no. 2 (Fall 1993): 350.

${ }^{527}$ T. Nicholson, "Road Maps and Advertising in Britain, 1860-1940," Cartographic Journal 45, no. 1 (February 2008): 43-61.

${ }^{528}$ J. Bowden, "That's The Spirit!: ROP and the British Oil Market, 1924-39," Journal of European Economic History 17, no. 3 (Winter 1988): 641-665.
} 
Hewitt's deconstruction of Shell print advertisements of the 1930s has revealed the close connections between the British modern art movement and the company's marketing strategy. ${ }^{529}$ The period of the 1930s is also covered in Karen Lynch's study of Shell advertising posters, as well in M. Evans' book on Big Oil and the Arts. ${ }^{530}$ Both analyze Shell's corporate patronage of the arts during the interwar years.

R. W. Ferrier is one of the few scholars to examine BP's motor spirit marketing activities during the interwar years. In the first volume of the official History of the British Petroleum Company (1982), Ferrier outlines the company's development of "an imaginative advertising campaign" during the 1920s, making several references to BP's early print advertisements and the Persian Khan exhibit, presented at the British Empire Exhibition of 1924-1925, as noteworthy examples of successful motor spirit marketing. ${ }^{531}$ Despite acknowledging the significance of these and other marketing activities to BP's overall sales strategy, Ferrier provides no analysis of their contents, the messages they delivered, or the audiences they reached. Thus, while Ferrier argues that BP had to "rely on quality and publicity to secure and keep [its] market," he provides no sense of what publicity measures were employed. ${ }^{532}$

\footnotetext{
${ }^{529}$ T. Sheppard and J. Hoole (eds.), That's Shell, That Is (London: Barbican Art Gallery, 1983); J. Hewitt, "The 'Nature' and 'Art' of Shell Advertising in the Early 1930s," Journal of Design History 5 (1992): 126. ${ }^{530}$ See K. Lynch, "Visit Britain's Landmarks: Follies on Shell Advertising Posters in the 1930s," The Follies Journal 5 (Winter 2005), and M. Evans, Artwash: Big Oil and the Arts (London: Pluto, 2015). There are several recent Ph.D. dissertations dedicated to this topic. See D. Wardleworth, "Building the Modern Corporation: Corporate Art Patronage in Interwar Britain." Ph.D. Dissertation. Southampton Solent University, 2002; M. Speakman, "Shell's England: Corporate Patronage and English Art in the Shell Posters of the 1930s." Ph.D. Dissertation. University of Manchester, 2014, and P. Vang, "Good Guys: A Cultural Semiotic Study of the Print Advertising of the Oil Industry (1900-2000)." Ph.D. Dissertation. Linköping University, 2014.

${ }^{531}$ R. Ferrier, The History of The British Petroleum Company, Vol. 1, The Developing Years, 1901-1932 (Cambridge: Cambridge University Press, 1982): 500.

${ }^{532}$ Ferrier, 1982, 500 .
} 
In his 1986 article, "Petrol Advertising in the Twenties and Thirties: the Case of the British Petroleum Company," Ferrier examines several motor spirit marketing activities undertaken by BP during the interwar period, including the outdoor sign campaign of the early 1920s, and the print advertising campaigns of the later 1920s. ${ }^{533}$ Ferrier links the development of BP's advertising strategy during this period to a dynamic and ever-increasing British motor spirit market, in which oil companies acquired an edge over their competitors by keeping their "name before the public." ${ }^{" 534}$ But the title of Ferrier's article is misleading. The bulk of his attention is dedicated to BP advertising of the 1930s, and there is only a brief summary of the company's marketing activities during earlier periods. Furthermore, while the article includes nearly a dozen reproductions of BP advertisements, none are dated earlier than 1923. Moreover, Ferrier's only comments on the ads are provided in a list of themes and motifs that he saw represented in their designs. His analysis of BP advertisements of 1923 to 1925, for example, is confined to the following list: "(a) Desirable qualities; (b) Advice and hints for motorists; (c) Best Possible; (d) British Pioneers; (e) Scientific appreciation." ${ }^{535}$ Added to this, Ferrier does not provide any citations in the article, and the only footnoted source material is his own History of the British Petroleum Company (1982). Neither publication contains critical analyses of BP motor spirit marketing activities during the early 1920s, while Ferrier's treatment of BP marketing during the 1930s leaves the impression that such activities performed the strictly utilitarian function of encouraging

\footnotetext{
${ }^{533}$ R. Ferrier, "Petrol Advertising in the Twenties and Thirties: The Case of the British Petroleum Company," European Journal of Marketing 20, no. 5 (1986): 29-51.

${ }^{534}$ Ferrier, "1986, 29-51.

${ }^{535}$ Ferrer, 1986, 37-38.
} 
more sales. The preponderance of charts and graphs containing sales data is evidence of Ferrier's business history approach.

The ideas about oil that were communicated in BP motor spirit marketing, and their contribution to the development of contemporary British petroculture, have not yet been taken into account. How did BP market its motor spirit products to British consumers during the period 1919-1925, and in what ways did those methods change over time? What images and stories were crafted by BP to attract the attention of potential consumers, and what were the key messages that the company sought to convey? In reconstructing these complicated histories of oil, this research argues that BP's early motor spirit marketing demonstrates how oil was interpreted and imagined in Britain during the early twentieth century.

\section{The Free Dealer Garage System and Competition in the British Motor Spirit Market}

From the outset, Britons were eager enthusiasts for oil-powered transportation technologies. During the late nineteenth and early twentieth centuries, vehicles such as motorcycles, motorcars, commercial vans and trucks, public taxis and buses, charabancs, and for the wealthiest of Britons, aeroplanes, became commonplace in many parts of Britain. ${ }^{536}$ In 1912, Britons purchased more than 20,000 new motor vehicles, and by 1929 the total number of such vehicles in the country had risen to 2.1 million. ${ }^{537}$ In London, the visible changes brought about by automotive technologies were dramatic. In a 1913 study, more than 5,000 motor vehicles were recorded to have passed through the city's

\footnotetext{
${ }^{536}$ A charabanc was a type of oil powered tour bus with an open-air cabin. "Visitors to Llandarcy," Naft 1, no. 2 (October 1924): 35-36. Leonard Raven-Hill commented on the use of such vehicles in the cartoon, "What Our Charabancs Have to Put Up With," Punch, 13 July 1927, 31.

${ }^{537}$ Royal Commission on Motor Cars, Vol. 1, Report, 1906, vol. 8, Cd. 3080, 11; Brunner, 1930, 223.
} 
Hyde Park intersection over a period of just six hours. ${ }^{538}$ The upward trend in oil-fuelled mobility continued during the 1920s. The number of motor vehicles in the country rose by nearly 650 per cent from 1919 to 1929 , and by the end of the decade seven per cent of the nearly thirty-two million motor vehicles in the world were driven on British roads. ${ }^{539}$ The use of oil for transportation purposes rose steadily and so too did the sale of motor spirits by British oil companies. Prior to the advent of the motor vehicle and aeroplane, petroleum spirits, or petrol, was practically a non-existent commodity in British markets, and constituted only a small fraction of overall oil imports. ${ }^{540}$ Overnight, it seemed, British motorists then transformed petrol into one of the most common and sought-after oil products in the country. In 1910, the Petroleum Review's annual list of oil products and their corresponding market values did not include motor spirits; in 1913, petrol represented one quarter of all the oil products sold in the United Kingdom. ${ }^{541}$ As one British oil expert observed in 1930, motor spirits became the "backbone of the oil trade of Great Britain., ${ }^{, 52}$

The rivalry for the allegiance of the new motorist was fierce among Britain's three largest oil companies, Anglo-American, Shell-Mex, and BP. As each company tried to outdo its competitors, the public found itself awash in motor spirit marketing. In response to this burgeoning of promotional activity, a body of literature emerged on the art and

\footnotetext{
${ }^{538}$ W. Antrobus, Oil (London: John Heywood, 1913): 91-92.

${ }^{539}$ Brunner, 1930, 95-96, 213-223. On automobiles and motoring in Britain, see S. O'Connell, The Car in British Society: Class, Gender and Motoring 1896-1939 (Manchester: Manchester University Press, 1998); J. Minnis, "A Lost Elysium? The motor car and England in the inter-war years," Local Historian 44, no. 4 (2014): 266-276.

540 The first records for the inland distribution of motor spirits in Britain date to 1903. Department for Business, Energy \& Industrial Strategy (UK), Crude Oil and Petroleum: Production, Imports and Exports 1890 to 2015 (London: HMSO, 2016).

${ }^{541}$ Petroleum Review, 4 January 1913, 17.

${ }^{542}$ Brunner, 1930, 90-91.
} 
practice of oil marketing in Britain. ${ }^{533}$ One of the most revealing studies was Christopher T. Brunner's, The Problem of Oil (1930), which offered a critical analysis of the intricacies and nuances of the British motor spirit market. ${ }^{544}$ Brunner was a senior BP employee in the 1920s, and his professional experience provided him with privileged knowledge of the company's downstream activities. ${ }^{545}$ In his book, Brunner argued that Britain was inundated by a "rising tide of oil," which had brought about a revolutionary transition to a new "oil age." Brunner's conclusions were far-reaching and unequivocal: "the world literally runs on oil," he proclaimed, a result largely of the "age of the internal combustion engine. ${ }^{546}$

A central topic of discussion in Brunner's study concerned the "rather peculiar" way in which motor spirits were distributed and sold in Britain, and the effects that this system had on the country's marketing environment. ${ }^{547}$ The greatest amount of petrol, he

\footnotetext{
${ }^{543}$ See P. Smith, The Shell That Hit Germany Hardest (London: Shell Marketing, 1919); D. Day, A Handbook of the Petroleum Industry (London: Chapman, 1922); E. McKnight Kauffer (ed.), The Art of the Poster: Its Origin, Evolution and Purpose (London: Cecil Palmer, 1924); Shell Oil Company, A Petroleum Handbook (London: the Company, 1933), and A. Rogers, "The Trend of Petrol Advertising," Art and Industry (June 1938). For examples of American publications on the theory of oil marketing, see Independent Oil Men's Association, Petroleum Annual: Handbook of the Petroleum Industry (Chicago: the Association, 1921); C. Jones, Service Station Management, Its Principals and Practice (New York: D. Van Nostrand, 1922); T. Boyd, Gasoline: What Everyone Should Know About It (New York: Stokes, 1925); Super Service Station (Chicago, 1928); American Petroleum Institute, National Code for Practices for Marketing Refined Petroleum Products (New York: the Institute, 1929); R. Thomas, The Merchandising of Petroleum Products (Des Moines: Homestead, 1929), and La Salle Extension University, Service Station Salesmanship (Chicago: the School, 1930).

${ }^{544}$ C. Brunner, The Problem of Oil (London: Ernest Benn, 1930). Brunner's research on car ownership and motor spirit sales has most recently been cited in P. Tertzakian, A Thousand Barrels a Second: the Coming Oil Break and the Challenges Facing and Energy Dependent World (New York: McGraw-Hill, 2007); L. Hughes and P. Lipscy, "The Politics of Energy," in M. Levi (ed.), Annual Review of Political Science, vol. 16 (2013): 449-469; V. Johnson et al., "Alternative Liquid Fuels in the UK in the Inter-War Period (19181938)," Environmental Innovation and Societal Transitions 20 (September 2016): 33-47.

${ }^{545}$ For other works by Brunner, see The Problem of Motor Transport: an Economic Analysis (London: Ernest Benn, 1928); Road Versus Rail: the Case for Motor Transport (London: Ernest Benn, 1929); Traffic Problems: With Particular Relations to South Wales (London: Institute of Highway Engineers, 1949); The Place of a Modern Road System in the National Economy (London: Town Planning Institute, 1952); Britain's Roads: Paralysis or Progress? (London: British Roads Federation, 1954), and Large-Scale Organisation and Change: A Study in Oil Marketing (London: Westerham, 1959).

${ }^{546}$ Brunner, 1930, 7-9, 213.

${ }^{547}$ Brunner, 1930, 215.
} 
noted, was sold through privately owned garages and service stations. Garages of the early 1920s provided a variety of different products and services to customers of all stripes. The largest of these businesses frequently engaged in motor vehicle rentals, the retailing of housewares and electrical appliances, and the provision of tea room services and lodgings. The sale of motor spirits was practically mandatory at most garages but, as Brunner's research made clear, the income derived from motor spirit sales was unreliable and insufficient by itself to sustain a business. The high cost of rent in the country's major urban centres during the immediate post-war years made it impossible for oil companies profitably to operate a selling station offering only one brand of motor spirit. ${ }^{548}$ At the same time, Brunner pointed out that there was a "mushroom-like growth of garages," as tens of thousands of mechanically inclined servicemen returned home after the war. ${ }^{549}$ By the end of the 1920 s, there were nearly 30,000 privately operated garages across the country, many of which sold motor spirits. ${ }^{550}$

The low margins on petrol sales forced garage owners to offer their customers as many brands of spirit as possible (usually three or four), so that, when motorists pulled into a garage to refuel, their preferred brand would be at the ready. As Brunner wrote, motor spirits were thus viewed as "a useful side-line" or as "bait for bigger fish." "551 If a particular brand was selling well, garages would order more, or perhaps install that

\footnotetext{
${ }^{548}$ During the 1920 s, the typical garage had two or three pumps, which each cost $£ 90-100$ to install. According to Brunner's calculations, a dealer sold an average of 550 gallons per month from each pump, making roughly $£ 170$ profit for the year. With rents in central London estimated to be as high as $£ 10,000$ in 1929, a petrol station would have to sell 5,000 gallons a month just to break even. Brunner, 1930, 93-97.

549 Brunner, 1930, 97.

${ }^{550}$ W. Braithwaite, Distribution of Motor Spirit in England, 2 May 1927. BP Archives, ARC H18/21. On the expansion of petrol stations in Britain, see "Magnificent New Petrol Filling Station Now Open," Sussex Agricultural Express, 6 May 1927, 3; "Design for Petrol Stations," Scotsman, 5 April 1929, 5; "First Steps to Stop Ugly Petrol," Lancashire Evening Post, 21 November 1929, 8.

${ }^{551}$ Brunner, 1930, 92.
} 
company's exclusive filling pump. If a spirit was selling poorly, or if customers

complained of low quality, new orders would be reduced or eliminated entirely. The garage owner held little allegiance to any one oil company, and it was the consumer who ultimately determined what brands were sold. This method of sales was called the "Free Dealer" garage system, and it had a significant impact on the marketing and selling of motor spirits in Britain during the late 1910s and early 1920s. ${ }^{552}$

Perhaps the most distinguishing feature of the free dealer system was the consumer's power to choose every time they filled up - would it be Shell, Pratts, or BP? The answer to this question depended on the preference of the individual driver, and it was determined by their knowledge of the different brands on offer and their views of the corresponding companies. During the early 1920s, therefore, the primary goal of British oil companies was to influence the minds of potential customers before they arrived at the garage. With such high stakes placed on "gaining the public's ear, and incidentally its purse," as Brunner quipped, motor spirit marketing became essential to the commercial success of British oil companies. ${ }^{553}$ As APOC's Naft magazine informed its readers in May 1931, the unique characteristics of the free dealer garage system meant that "demand, therefore, must come from the public." ${ }^{554}$ In accordance with Brunner's observations, the magazine asserted that innovative marketing was the most effective means to increase sales. "[A]dvertising charges must necessarily be somewhat heavy,"

\footnotetext{
${ }^{552}$ The British Free Dealer garage system was radically different from the Tied Garage or Solus System used in Canada and the United States, in which oil companies struck bilateral deals with private garages to sell their brand of motor spirit exclusively, or which sold spirits from company-built filling stations. It was not until after the Second World War that the Solus System was adopted in Britain. D. Dixon, "The Development of the Solus System of Distribution in the United Kingdom, 1950-1960," Economica 29, no. 113 (1962): 41-52.

${ }^{553}$ Brunner, 1930, iii, 76.

554 “The Persian Oil Industry - the Final Stage of Distribution," Naft 7, no. 3 (May 1931): 25-30.
} 
for among the British motoring public "publicity is a consideration second only to the quality of the goods...Publicity and advertising in their turn strengthen the public demand for branded spirit." ${ }^{555}$ Put another way, advertising was the price of doing business.

\section{The British Petroleum Company and the Development of a Marketing Strategy}

The British Petroleum Company, Ltd. (BP) was formed in London in June 1908 by the German oil company, Europäische Petroleum Union, and was initially responsible for the marketing and distribution of Shell motor spirits in the United Kingdom. ${ }^{556}$ Over the following decade, BP grew into the third-largest oil distribution company in Britain, employing some 3,000 British workers, operating 850 supply depots, and servicing one third of the overall British motor spirit market. ${ }^{557}$ During the First World War, the British Government heavily restricted the personal consumption of petroleum, and it forced Britain's oil companies into a "Pool" arrangement under which they were not permitted to advertise or even display brand logos. ${ }^{558}$ The war further interrupted BP's corporate trajectory when, in 1916, the German-owned company was classed as an enemy concern and placed in a public trust. In May 1917, BP was broken up and sold off, with the largest component going to the Anglo-Persian

\footnotetext{
${ }^{555}$ Naft, May 1931, 25-26.

${ }^{556}$ Anglo-Persian Oil Company, "Report of the Directors and Balance Sheet," 1915-1917. BP Archives, ARC 29854/3-29852/3; Ferrier, 1986, 29. The Europäische Petroleum Union was formed in London in June 1907. In addition to motor spirits, BP also distributed a variety of other refined oil products, including T.V.O. (Tractor Vaporising Oil); P.V.O. (Pure Vaporising Oil); Royal Standard lighting oil; White May lamp oil; Resoleum furnace fuel, and Gasoleum diesel fuel. BP, "Motor Spirit," 1926. ARC $33 / 02196$.

${ }^{557}$ Ferrier, 1986, 29; BP Archives, "Finding Aid," ARC 104205-102027. The Anglo-American Oil Company was the largest distributor of motor spirits in Britain during the period; Shell-Mex and ROP were the second and fourth largest, respectively.

558 "The Dawn of Decontrol," Petroleum Times, 1 November 1919, 121; S. Nearing, Oil and the Germs of War (New York: Nellis, 1923); A. Mohr, The Oil War (New York: Harcourt Brace, 1926); T. Winegard, The First World Oil War (Toronto: University of Toronto Press, 2016).
} 
Oil Company. ${ }^{559}$ According to the historian Ferrier, APOC's acquisition of BP represented "the missing link" - marketing and advertising - in the company's global oil empire, and the "keystone in the arch of an integrated oil company." $560 \mathrm{BP}$ was an oil marketing company that provided APOC, an exploration and extraction company, with a mechanism for selling refined Persian oil products directly to the British consumer.

In the years that followed the First World War, the members of BP's new board of directors devised a comprehensive strategy for marketing APOC's motor spirits in Britain. In charge of this mission was BP's General Manager, W.T. Watts, whose personal correspondence with other BP executives during this period reveals much about the evolution of the company's earliest marketing activities. In a letter written in January 1920 to a fellow board member, H.E. Nichols, Watts complained that the company had "nothing of interest to show" its customers, except "a few balance sheets. We have not even a decent set of photographs," he lamented. ${ }^{561}$ At the $104^{\text {th }}$ Meeting of the BP Board, held in London in September 1920, Watts urged his colleagues to invest in a campaign designed to "arouse demand" for BP motor spirits, and to increase "our infant organization's place on the market." ${ }^{262}$ After learning of the dearth of marketing

\footnotetext{
559 "War Supplies from the Enemy," Manchester Courier, 27 November 1914, 4; "Probate, Divorce, and Admiralty Division," The Times, 4 May 1915, 3; "Anglo-Persian Oil Company," Western Mail, 7 June 1917,3 . APOC invested $£ 2,650,000$ for its share of BP, the 2018 equivalent of $£ 215$ million. The second largest share of BP's assets went to the Shell Marketing Company. For discussion of the wartime experiences of BP and the Anglo-Persian Oil Company, see R. Ferrier, 1982, 202-261; D. Yergin, 1991, 151-167.

${ }^{560}$ Ferrier, 1982, 219; Ferrier, 1986, 30.

${ }^{561}$ Correspondence of W.T. Watts, Esq., British Petroleum Co., 1919- 1922. BP Archives, ARC 70007; "H. E. Nichols to W. T. Watts," 12 January 1920; "W. T. Watts to H. E. Nichols," 13 January 1920; "Peter Donovan to W. T. Watts," 11 March 1921. W. T. Watts was General Manager of BP until 1921, when he was transferred to the Anglo-Persian Oil Company to manage the "Foreign Countries" file. H. E. Nichols was a personal assistant to William Knox D'Arcy from 1901-1909, and a Director of the Board of BP from 1915-1927. Peter Donovan was APOC's Publicity Manager during the 1920s. Ferrier, 1982, 694.

562 “Advertising," $89^{\text {th }}$ Meeting of the Board, 22 October 1919; "Advertising," $104^{\text {th }}$ Meeting of the Board, 21 September 1920.
} 
materials at the company's disposal, BP executives left the board room in agreement that "our advertising must be on a very extensive scale indeed." 563

The first steps taken by BP occurred in February 1921, with the creation of a new Publicity Department charged with the task of increasing public demand for its oil products. Shortly after its formation, Watts was transferred to APOC, and another board member, W. D. Braithwaite, was put in charge of the new Department. ${ }^{564}$ In the months leading up to the summer driving season of 1921, Braithwaite initiated the first major marketing campaign in BP's history - an outdoor advertising blitz, which resulted in the erection of 12,000 enamelled-iron signs, 6,000 outdoor sign boards, and many thousands more posters and lorry bills at train stations, along rural and urban roadways, and at private garages across the country. ${ }^{565}$ These signs and posters were simple but effective in their design and messaging. [Figure 12]. All forms of outdoor advertising displayed the company's distinctive brand logo (the letters 'B.P.'), as well as the house colours (initially green and red, but later green and yellow), while many signs placed along public roadways provided directions to the nearest filling station. ${ }^{566}$ The inaugural campaign

563 “Advertising," 104 $4^{\text {th }}$ Meeting of the Board, 21 September 1920.

${ }^{564}$ W. D. Braithwaite was a founding Director of the British Petroleum Company, and responsible for the advertising and marketing of BP motor spirits during the early 1920s. In 1927, he joined APOC as the Joint Deputy-Director of Distribution. Ferrier, 1982, 305.

565 "Advertising," 104 $4^{\text {th }}$ Meeting of the Board, 21 September 1920; "Advertising," $122^{\text {nd }}$ Meeting of the Board, 21 February 1922; "Advertising," $126^{\text {th }}$ Meeting of the Board," 3 August 1922. On the development of American outdoor advertising during the early twentieth century, see E. Francis, "Structural Standardization of Outdoor Advertising," Advertising Outdoors (July 1928): 7; H. Agnew, Outdoor Advertising (New York: McGraw-Hill, 1938); D. Sauder, "A Glorious Half Century of Outdoor Advertising," Sign of the Times 143, no. 1 (May 1956): 112; D. Hendon, "Origin and Early Development of Outdoor Advertising in the United States," European Journal of Marketing 20, no. 5 (1986): 7-17. 566 “Advertisements Regulation Bill," House of Lords Debate, vol. 54, cc. 8-20. 8 May 1923; Report of the Petroleum Filling Stations Committee (London: HMSO, 1929): 7; Ministry of Transport (UK), Petrol Stations (London: HMSO, 1949). Garages that sold motor spirits were typically the site of much oil marketing activity, including the hanging of enamelled iron signage, the distribution of company-produced road maps, and the placement of branded motor spirit pumps. See "Vulgar' Advertising," The Times, 28 March 1922, 9; "Beauty and the Pump," The Times, 20 August 1930, 11; R. Brown, "Cultivating a 'Green' Image: Oil Companies and Outdoor Publicity in Britain and Europe, 1920-1936," Journal of European Economic History 22, no.2 (Fall 1993): 355. 
was a tremendous success, and Braithwaite informed his colleagues on the board that the activities of the new Publicity Department had "materially helped sales." agreed and approved an additional budget of $£ 20,000$ (the 2018 equivalent of $£ 1$ million) for the 1922 marketing campaign. ${ }^{568}$

Figure 12: BP Motor Spirit ghost sign (c. 1924), King's Cross, London

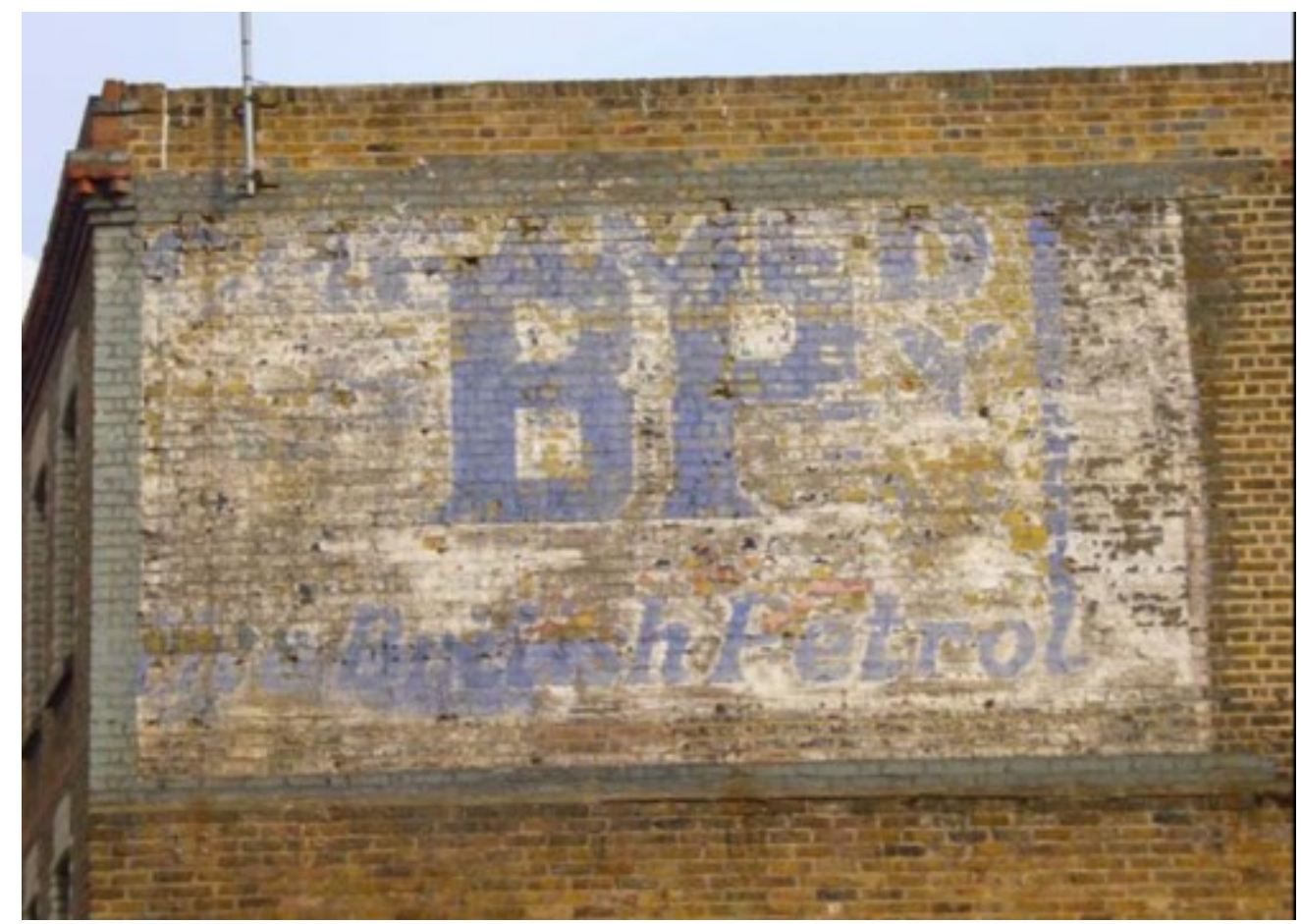

History of Advertising Trust. ${ }^{569}$

\footnotetext{
567 “Advertising," $114^{\text {th }}$ Meeting of the Board, 19 July 1921. Sales of BP motor spirit had been increasing for several years. In December 1919, the company sold 65000 gallons of motor spirits, while in January of 1920, the company sold more than 662000 gallons. $98^{\text {th }}$ Meeting of the Board, 24 March 1920.

568 "Advertising," $116^{\text {th }}$ Meeting of the Board, 25 October 1921. BP's advertising budget was relatively small, particularly in light of the fact that Braithwaite's salary in 1923 was $£ 10,000$. "Motions," $139^{\text {th }}$ Meeting of the Board, 14 November 1923.

569 "Ghost sign: BP," History of Advertising Trust, HAT60/171. Retrieved from: www.hatads.org.uk/catalogue/record/fbbecbd8-fda7-4b27-bc8a-abd25743a175.
} 
Braithwaite used his enlarged marketing budget to develop new methods of catching the attention of British consumers. He began distributing promotional materials to private garages and filling stations, including illustrated booklets and pamphlets; road maps and driving guides; branded stationary and sundry novelty items. ${ }^{570}$ On a larger scale, the Publicity Department began experimenting with illuminated roadside signs, as well as reflective "light catching" signs in places where artificial light was not permitted, most particularly in rural villages. ${ }^{571}$ These outdoor advertisements continued to present the company logo and to offer directions to local filling stations, only with greater panache and visual appeal. In addition to these stationary outdoor advertisements, BP deployed several forms of mobile oil marketing during the early 1920s. The company placed advertisements on London city buses, and branded its fleets of oil tankers, rail tank-cars, and motorized delivery vehicles with the company's "BP" logo. ${ }^{572}$ The most common form of outdoor advertising undertaken by BP was circulation of the company's 2-gallon motor spirit cans, which were used to distribute BP products across the country. ${ }^{573}$ Braithwaite's Publicity Department had conducted its first advertising campaign on a very extensive scale.

\footnotetext{
570 "Advertising," $111^{\text {th }}$ Meeting of the Board, 19 April 1921; "Advertising," $122^{\text {nd }}$ Meeting of the Board, 21 February 1922; "Our Advertisers," Wells Journal, 11 August 1922, 5.

${ }^{571}$ In 1923, the erection of BP roadside signs was forbidden in the counties of Gloucestershire, Hampshire, Somerset, and Westmoreland, where a surge in complaints of spoiling the landscape had forced local officials to institute bans. By 1925, ninety-three different authorities had introduced regulations against outdoor oil advertising. "Roadway Signs in Hampshire," $131^{\text {st }}$ Meeting of the Board, 23 January 1923; "Road Advertising Signs," 134 ${ }^{\text {th }}$ Meeting of the Board, 22 May 1923; Brown, 1993, 348-349.

572 “Advertising 'B.P.' Spirit," $126^{\text {th }}$ Meeting of the Board, 3 August 1922; “Motor Vehicles," $151^{\text {st }}$ Meeting of the Board, 22 October 1924.

573 "Advertising Globes on Roadside Pumps," $161^{\text {st }}$ Meeting of the Board, 22 July 1925; "Kerbside Pumps," $166^{\text {th }}$ Meeting of the Board, 21 January 1926. By 1925 there were estimated to be over two million of the Company's 2-gallon cans circulating in Britain, all stamped with the letters "B.P."
} 
In August 1922, just two years after Watts had first expressed his concerns about the BP's near-complete lack of marketing materials, Braithwaite informed board members that "most of the country...[was] fairly well covered" in the company's outdoor advertising. ${ }^{574}$ For his efforts, Braithwaite was rewarded with a budget increase for 1923 , which board members raised by a factor of six, to $£ 120,000$ ( $£ 6.2$ million in 2018 ). ${ }^{575} \mathrm{As}$ the Illustrated London News commented in 1924, in "modern times," advertising for consumer products "evolved by a slow process of guess and trial rather than through any ordered philosophical policy." ${ }^{576}$ This observation certainly holds true for Braithwaite's Publicity Department during these early years. In the spring of 1923, flush with funding, he ordered a major restructuring of the unit, with changes ranging from a new name (the Advertising Department) to the hiring of a "highly qualified advertising expert." ${ }^{1577}$ The following year, the Department held a competition among BP employees to develop a new company logo, which was won by a distribution clerk. The design added accentuated serifs to the existing 'BP' logo, and was applied to company buildings, delivery vehicles, rolling stock, and oil carrying vessels, as well as the globes on top of motor spirit pumps, letterheads, dividend reports, and print advertisements. ${ }^{578}$ The restructuring and rebranding were successful in further driving up sales of BP products, and the board

\footnotetext{
574 “'Advertising 'B.P.' Spirit,” $126^{\text {th }}$ Meeting of the Board, 3 August 1922.

575 The total expenditure on advertising in the United Kingdom for 1923 was $£ 175$ million, which in 2017 figures is the equivalent of $£ 9.7$ billion.

576 "An Industry that Makes Industries," Illustrated London News, 19 July 1924, 132.

577 "Road Advertising Signs," 134 $14^{\text {th }}$ Meeting of the Board, 22 May 1923. In March 1924, BP forced the long-time Head of the Advertising Department, A.W. Werill, to retire by cutting his salary in half. "Mr. A.W. Werill," $145^{\text {th }}$ Meeting of the Board, 19 March 1924.

578 “Advertising," $159^{\text {th }}$ Meeting of the Board, 20 May 1925; Ferrier, 1986, 36.
} 
subsequently raised the advertising budget for 1924 to $£ 150,000$, and for 1925 to $£ 175,500$ (the 2018 equivalent of $£ 8.3$ and $£ 9.2$ million, respectively). ${ }^{579}$

The most expensive component of BP's motor spirit marketing strategy during the 1920s was print advertising. The company had been publishing advertisements in British newspapers since November 1919. ${ }^{580}$ These advertisements were strictly functional documents that conveyed to the reader information about the company's products and where they could be found. As one advertisement published in a local newspaper in May 1920 announced in simple block print: “'B.P.' Motor Spirit is now available at all leading garages in Kent \& Sussex." $" 581$

Starting in 1921, however, BP's print advertisements became more sophisticated. The simple, utilitarian messages of previous years were replaced by images and text that told more elaborate stories about the company's oil products. A frequent subject of BP press advertising in the early 1920 s was the free dealer garage, and the motorist's experience of filling up. An ad published in The Times in May 1921, and which later appeared in the Illustrated London News, the Illustrated Sporting and Dramatic News, Sketch, and Tatler, featured an illustration of the smiling BP man, dressed in coveralls,

\footnotetext{
579 “Advertising Expenditure," $144^{\text {th }}$ Meeting of the Board, 19 February 1924; "Advertising Grant," $157^{\text {th }}$ Meeting of the Board, 25 March 1925; "Advertising," $159^{\text {th }}$ Meeting of the Board, 20 May 1925. By comparison, BP’s net profits for the fiscal year 1924/1925 amounted to $£ 323,000$. "Advertising," $160^{\text {th }}$ Meeting of the Board, 24 June 1925. Anglo-American and Shell-Mex invested $£ 200,000$ and $£ 30,000$, respectively, on print advertising in 1925. "Sale of Products," $161^{\text {st }}$ Meeting of the Board, 22 July 1925. 580 The first BP advertisement was published in the Petroleum Times in November 1919. It provided information about the end of the wartime restrictions on petroleum. "The Dawn of Decontrol," Petroleum Times, 1 November 1919, 121. A few days later, BP published its second advertisement in Autocar, which encouraged readers to visit the company's booth at the Olympia Motor Show, the first post-war exhibition of its kind, held at London's Crystal Palace in November 1919. There they could inspect samples of the company's oil products first-hand. "Stand No. 327," The Autocar, 8 November 1919, 55; H. Buist, "The Olympia Motor Show," British Medical Journal (8 November 1919): 601-604.

At the 3 August 1922 meeting of the board, Braithwaite informed his colleagues that the use of print advertisements would begin to increase "whilst the more permanent class of [outdoor] advertisement would be progressively reduced." "Advertising," $126^{\text {th }}$ Meeting of the Board, 3 August 1922.

${ }^{581}$ Kent \& Sussex Courier, 7 May 1920, 3.
} 
picking up several 2-gallon cans labelled "BP Motor Spirit." ${ }^{582}$ He stood in front of a brick building labelled "Garage," which housed in one of its service bays a contemporary luxury vehicle. Hanging above the door of the garage, and figuring prominently above the head of the BP man, was an example of one of BP's early enamelled-iron signs, which carried the BP logo on top of the Union Jack. The text of the advertisement presented a simple, direct message to the reader: "Put the best possible in your tank and get the best possible out of your car."

The garage scenes depicted in BP advertisements published during the summer driving season of 1921 constructed a registry of images and stories that explained the process of filling up. By showing the look and feeling of pulling into a garage, and filling up with BP, the ads primed the reader-cum-motorist to ask for the company's product on their next visit. In another advertisement published in the Manchester Guardian in late May 1921, the BP man was once again depicted standing beneath an enamelled sign in front of the garage, but on this occasion inspecting a BP can held out in front of him. ${ }^{583}$ At the bottom of the ad, a section of text informed readers that they could depend upon BP motor spirit for "easier starting, increased power, cleaner combustion and greater mileage." As it so often is in print marketing, the messages delivered in BP's advertisements of the early 1920s were straightforward and unequivocal: "Best Possible and there's nothing to beat that!" 584

582 “"BP' Motor Spirit,” The Times, 11 May 1921, 15; Sketch, 18 May 1921, 39; Illustrated Sporting and Dramatic News, 21 May 1921, 25; Tatler, 25 May 1921, 41; Illustrated London News, 28 May 1921, 735. 583 ““BP’ Motor Spirit,” Manchester Guardian, 27 May 1921, 4; Scotsman, 26 May 1921, 10; Western Morning News, 27 May 1921, 7; Sketch, 1 June 1921, 37; Illustrated London News, 4 June 1921, 771; Bystander, 8 June 1921, 43; Graphic, 11 June 1921, 23; The Times, 24 June 1921, 9. 584 “'BP' Motor Spirit,” Graphic, 27 August 1921, 257. 
A second narrative thread running through BP's print advertisements of the early 1920s was the motorist's relationship with their vehicle. The images and stories presented in the advertisements focused on themes such as pleasure, satisfaction, dependability, confidence, performance, and exhilaration in order to encourage the reader to think about how they felt when purchasing and using BP motor spirit. An advertisement published in Autocar in December 1921 explained in precise terms that BP motor spirit offered "More Miles and Mores Smiles - Eh?" 585 Other ads leveraged a sense of compassionate patronage between motorists and their vehicle, akin to farmers and their livestock, or pet owners and their dogs. "Be kind to your engine," pleaded an advertisement published in the Observer in June 1921, and "use the Best Possible fuel."586 The technique of anthropomorphosis was also used to engage readers, and to persuade them to think of themselves and their vehicles in imaginative ways. "Your engine is almost human," proclaimed an ad published in the Sphere in July 1921, and should be filled with "the essentially 'clean' spirit." ${ }^{257}$ In the garage scene depicted in these ads, the attendant stood next to a contemporary sedan, filling it with spirit from a 2-gallon container labelled 'BP.' Unlike the other documents in this series, the BP man locks eyes with the reader as he fills the motorcar, and smiles with approval at the choice that has been made.

The depiction of sporting events was another feature of BP print advertisements of the early 1920s. These ads, in particular, offer important insight into BP's intended audience, namely affluent Britons with the money to own and operate a motor vehicle and the time to engage in sport. As one advertisement published in the Sphere in April

\footnotetext{
585 “"BP' Motor Spirit,” Autocar, 31 December 1921, 49.

586 “"BP’ Motor Spirit,” Observer, 26 June 1921, 22; The Times, 8 July 1921, 6.

587 “'BP' Motor Spirit,” Sphere, 2 July 1921, 32; Tatler, 29 June 1921, 47; Sketch, 29 June 1921, 35.
} 
1921 stated confidently, BP was for those who possessed the "Sporting Spirit." ${ }^{\circ 88}$ The ad contained a large illustration of a luxury motorcar, filled with young men and women, pulling up to a crowded country clubhouse - "Wise golfers use the 'Best Possible.",589 According to another advertisement in the "Sporting Spirit" series, BP products were "so much in evidence on our Cricket Fields" because only the "Best Possible' is worthy of the game. ${ }^{, 590}$ Horse racing was also depicted in an ad published in the Illustrated London News in June 1922, which featured a scene of a winning racehorse surrounded by celebrators. [Figure 13]. At the side of the image was a large sedan containing a uniformed chauffeur and three passengers - the chauffeur is attending to the windshield; a woman holds a parasol; another woman is waving a handkerchief; and a man dressed in a top-hat is raising his cane in the air in celebration. Affixed to the running board of the vehicle was one of BP's 2-gallon motor spirit cans. The foreground of the image was taken up by a photograph of the BP man from the 1921 ads. Dressed in coveralls and carrying a BP can and a funnel, he smiles in the direction of the reader: "Nothing is so hard on your car as the congested traffic near the race-course." Linking sophistication and down-to-earth, and upper and working classes, the recurring words in BP's advertisements explained, "[ $\mathrm{t}]$ hat is the time when you must have the 'Best Possible.",591 BP's early press advertisements performed an important role in the development of the company's overall marketing strategy. They guided potential consumers to the locales dispensing BP motor spirit, and they narrated the experience of pulling in,

\footnotetext{
588 “'BP' Motor Spirit,” Sphere, 6 August 1921, 28; Illustrated Sporting and Dramatic News, 6 August 1921, 27; Graphic, 6 August 1921, 27; Bystander, 17 August 1921, 47.

589 “The Sporting Spirit," The Times, 7 April 1922, 8.

590 “The Sporting Spirit," Illustrated London News, 20 May 1922, 761.

591 "The Sporting Spirit," Illustrated London News, 3 June 1922, 841; Gloucester Citizen, 23 June $1922,5$.
} 
encountering the smiling, helpful BP man, and filling up their motor cars. The advertisements showcased the company's other advertising activities, such as the displaying of branded signs. It appears that every BP advertisement published in 1921 and 1922 included a small image of the BP Union Jack logo, accompanied by the message, "Look for this Sign.” BP's press advertisements did what outdoor advertisements could not - they showed the company's product being used, and told stories about how the motorist would feel if they asked for BP. 
Figure 13: "The Sporting Spirit"

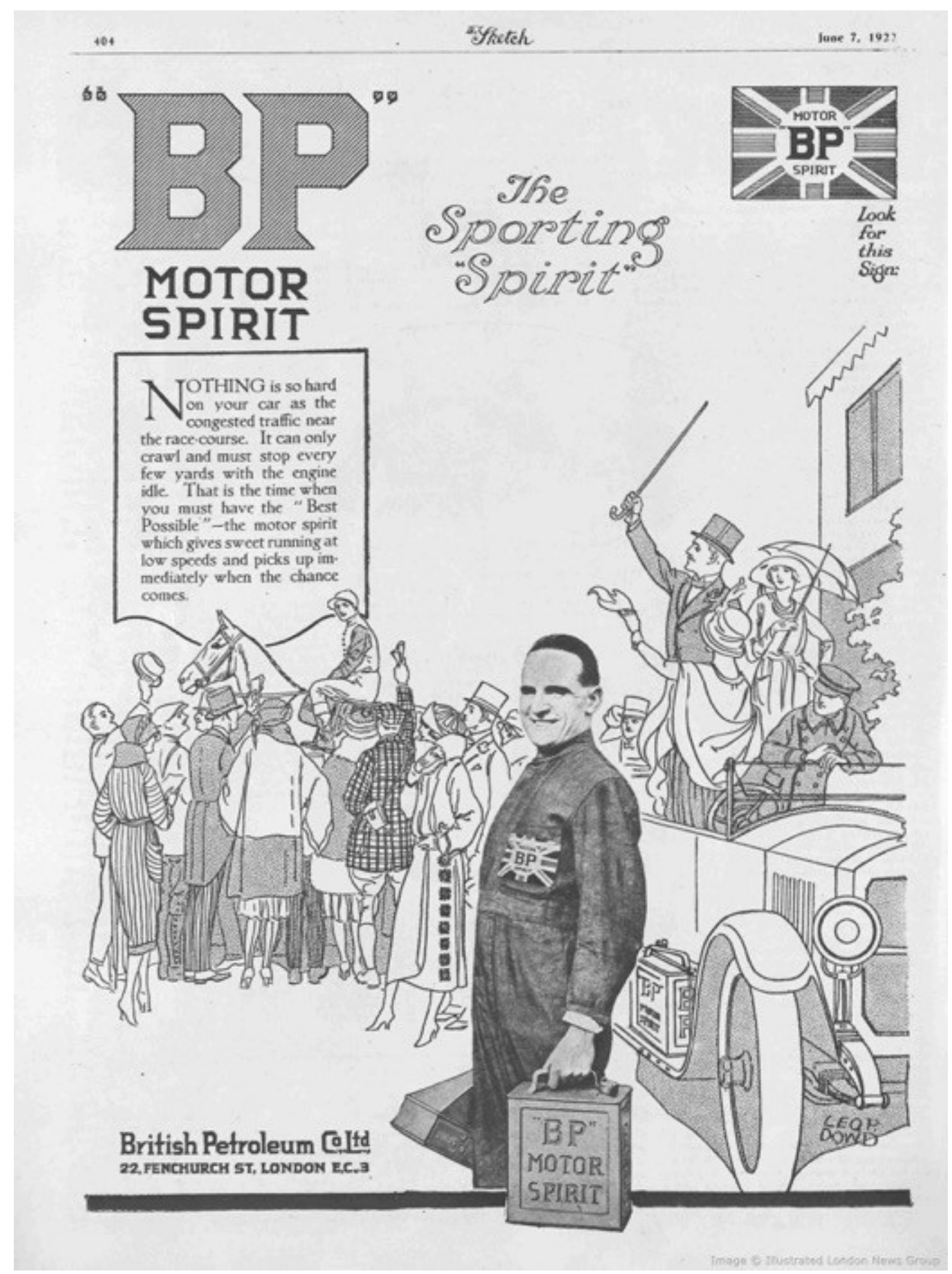

The Sketch, 7 June 1922. 
Braithwaite, as the person responsible for the advertising and marketing of $\mathrm{BP}$ motor spirits during the early 1920s, was adamant that "[a]dvertisements to be effective should be perpetually taking new lines. ${ }^{" 592} \mathrm{He}$ recognized that creativity and imagination were at the heart of successful motor spirit marketing, and during the summer driving season of 1923 he initiated a campaign that featured a new registry of images and stories about oil. The number of newspapers and magazines in which BP advertisements were published was also significantly increased in 1923, with several regional publications being added to the company's readership, including the Leeds Mercury; the Hartlepool Daily Mail; the Birmingham Daily Gazette; the Western Morning News, and the Coventry Evening Telegraph. ${ }^{593}$

The free dealer garage continued to be a common subject in BP print ads of 1923, but the advertisements were rendered in much richer detail. Several advertisements published in April and May explained the manner in which oil products were distributed in Britain, and described the infrastructure that brought BP spirits to a local garage. An ad published in The Times in April 1923 featured an illustration of the "handsome 'BP' Lorry, resplendent in red and green," which delivered the company's products to communities across the country. ${ }^{594}$ According to the text of the ad, BP's branded delivery truck had become "a familiar and welcome sight in every English Village." A similar type of bulk delivery vehicle was showcased in the ad entitled "The 'BP' Tank Wagon," first published in the Western Daily Press in April 1923, which included an illustration of

\footnotetext{
592 "Press and General Advertising," 135 th Meeting of the Board, 19 June 1923.

593 “The 'BP' Lorry," Leeds Mercury, 28 March 1923, 11; Hartlepool Northern Daily Mail, 29 March 1923, 5; Birmingham Daily Gazette, 28 March 1923, 9; Western Morning News, 28 March 1923, 2; Coventry Evening Telegraph, 20 July 1923, 6.

594 “The 'BP' Lorry," The Times, 6 April 1923, 12; Illustrated Sporting and Dramatic News, 26 May 1923, 39; Tatler, 30 May 1923, 39.
} 
a delivery being made at a large garage. ${ }^{595}$ In the advertisement, "The Advance Party," published in Tatler in July 1923, BP's effort to educate readers on the "behind-thescenes" aspects of British oil distribution was in full view. ${ }^{596}$ The ad featured an illustration of a BP truck making a delivery to a local garage. The setting was rural, with narrow, winding streets and half-timbered style buildings with thatched roofs. The roof material signals a village in southern England, and the kind of setting that a motorist might have reached after an extended exploration of the countryside, made possible by the motorcar. A sign carrying the BP Union Jack logo hung above the doorway of a building, clearly identifying it as a garage. The driver of the BP delivery vehicle is leaning out of his window, chatting with a local man. "Has it ever occurred to the great army of holiday makers who use the road that an Advance Party has prepared the way for them?" the ad asked. Regardless of their answer, customers of BP could travel assured that the "Holiday Army is safe with British Petroleum." ${ }^{\text {" }} 57$ The military language invokes the imagery of the battlefields of Europe, and the organization and coordination required to perform a mission.

In the fall of 1923, Braithwaite initiated another major shift in BP's print advertising strategy - a pivot toward Persia. BP's parent company, APOC, offered a unique marketing opportunity, one that would set BP apart from its competitors. A much larger company with a global presence, APOC had a fascinating history, and it operated in an exotic foreign land. As Braithwaite later explained to his colleagues on the board, BP's association with the company and its Persian crude oil was a "great

\footnotetext{
595 “The 'BP' Tank Wagon,” Western Daily Press, 20 April 1923, 3; Manchester Guardian, 29 April 1923, 22; The Times, 4 May 1923, 19; Illustrated London News, 19 May 1923, 881.

596 "The Advance Party," Tatler, 25 July 1923, 43; Sketch, 25 July 1923, 46; The Times, 24 August 1923, 5.

597 "The Advance Party," Bystander, 29 August 1923, 71.
} 
advertising asset." ${ }^{" 598}$ In 1924, the words "Anglo-Persian Oil Company" began appearing on BP stationary, a move designed to create "a closer association in the mind" between Persia and BP motor spirit. ${ }^{599}$ Stories about Persia first appeared in BP print advertisements in late 1923. Like those published in earlier years, the ads in this campaign were intended to both educate and entertain British readers. They explained the key processes and technologies that brought oil to the consumer, and they narrated the experience of using BP products. However, unlike their predecessors, the advertisements from 1923 onwards focussed their gaze on Persia and the foreign landscapes where BP spirits originated.

One of the earliest examples of BP's Persian-inspired print advertisements was published in several British newspapers and magazines in September $1923 .{ }^{600}$ Entitled "From Persia to You," the advertisement used a combination of images and text to tell the story of BP motor spirits making their way from the crude wells in Persia to the roadside pump in Britain. A series of illustrations depicted this journey - oil derricks set against a mountainous backdrop in Persia; local Persian workers guiding a team of donkeys laden with sections of pipeline, and the Llandarcy Refinery in South Wales. The accompanying text described the images using language reminiscent of Redwood's lectures on petroleum. The reader was brought back "[m]any centuries ago," to a period in which "Fire-Worshippers built their temples near the Petroleum

\footnotetext{
598 “Advertising," $160^{\text {th }}$ Meeting of the Board, 24 June 1925.

599 “Advertising Campaign," $133^{\text {rd }}$ Meeting of the Board, 20 March 1923. In July 1924, APOC created a Persian-inspired staff magazine, the Naft-i-Iran (later Naft), which in Farsi meant "The Oil of Persia." "Our First Number," Naft 1, no. 1 (July 1924): 25-26; A. Black, “"A Valuable Handbook of Information': The Staff Magazine in the First Half of the Twentieth Century as a Means of Information Management," in T. Weller (ed.), Information History in the Modern World: Histories of the Information Age (Houndmills: Palgrave Macmillan, 2011): 142.

600 "From Persia to You," Illustrated London News, 1 September 1923; Tatler, 5 September 1923; Sketch, 12 September 1923; Illustrated Sporting and Dramatic News, 29 September 1923.
} 
springs of Persia. ${ }^{601}$ In this remote age, the advertisement explained, oil was used in primitive ways; Persians "rubbed petroleum on their camels. They even drank it as a medicine. ${ }^{\prime 602}$ The high point of Persian culture had long since passed, but fortunately for British motorists, the ad informed readers, the country's rugged and barren landscapes had been transformed by the modern science and technology of the twentieth century. The prize of this commercial conquest was "precious oil in an unending stream," which APOC and BP delivered directly to local garages across the country. ${ }^{603}$ The underlying message of "From Persia to You" was that motor spirits made from Persian crude oil possessed special qualities that could improve an automobile's performance and reliability. Expressed in more imaginative ways, the ad suggested that the Persian origins of BP motor spirit made it stand out among its competitors, providing the motorist with an exotic, powerful, and almost magical fuel - "clear, white, volatile, and ready for the electric spark to transmute it into pure energy." ${ }^{604}$

The narrative that Persia imbued BP motor spirits with characteristics not seen in its competitors' fuels was expressed in several other print advertisements published in 1924. According to a series of ads entitled "You can do it easily on 'BP,"” the "special qualities of Persian crude oil, from which it is produced, give to 'BP' its unique degree of volatility." ${ }^{605}$ Another advertisement promoting the commercial uses of BP motor spirit claimed that the "richness of Persian crude oil and the care with which it is refined are

\footnotetext{
601 "From Persia to You," Illustrated Sporting and Dramatic News, 29 September 1923, 49.

602 "From Persia to You," Illustrated London News, 1 September 1923. Boverton Redwood discussed the ancient uses of petroleum as a pharmaceutical product in Cantor Lectures on Petroleum and Its Products (London: Trounce, 1886); Petroleum (London: Charles Griffin, 1896); "Petroleum," Encyclopedia Britannica, Vol. 21 (1911): 321-333.

603 "From Persia to You," Illustrated Sporting and Dramatic News, 29 September 1923, 49.

604 "From Persia to You," 1923, Tatler, 5 September 1923.

605 "You can do it easily on 'BP,"” Western Daily Press, 3 April 1924, 3; Hull Daily Mail, 10 April 1924, 7;

The Times, 14 April 1924, 9; Manchester Guardian, 16 May 1924, 5.
} 
your guarantee that 'BP' will always give you maximum power and minimum trouble. ${ }^{\circ 606}$ Here, again, the themes of dependability and performance are foregrounded, as is the affective relationship between a motorist and their vehicle. "Cars run best on 'BP,"' it was asserted in the final advertisement in the series, "because it is refined from the rich crude oil of Persia, and is produced by the most modern methods known to science. $" 607$

The centerpiece of BP's Persian-inspired print advertising campaign was the twelve-part "Persian Series," which was published in several magazines and newspapers during the spring and summer of 1925, including the Illustrated London News, the Illustrated Sporting and Dramatic News, the Bystander, the Sphere, and the Tatler. ${ }^{608}$ The elaborate, full-page advertisements each consisted of two communicative elements: a large composition of artwork that depicted scenes of Persian history, geography, and culture, and several paragraphs of text that described the artwork and conveyed stories about the British consumer's special relationship with Persian oil and BP.${ }^{609}$ Collectively, the advertisements of the "Persian Series" created an imaginary world of oil in which exotic geographies inhabited by "other" peoples produced energy for civilized, urban, British consumers.

606 "You can do it easily on 'BP,"” The Times, 28 April 1924, 7; Scotsman, 6 June 1924, 4; Aberdeen Press and Journal, 6 June 1924, 4.

607 "You can do it easily on 'BP,"” The Times, 6 August 1924, 12; Manchester Guardian, 10 August 1924, 16; Illustrated London News, 16 August 1924, 331; Bystander, 3 September 1924, 55.

${ }^{608}$ The "Persian Series" consisted of "The Petroleum Beacon," ARC 33/02144; "The Glories of Ancient Persia," ARC 33/02145; "Transporting Pipe Line in Persia," ARC 33/02146; "The Tomb of Khusru Pharviz," ARC 33/02147; "Ferry Boats of the Tigris," ARC 33/02148; "When Petroleum was used as Cement," ARC 33/02149; "A Land of Leisurely Travel," ARC 33/02150; "Petroleum as a Weapon," ARC 33/02151; "A Persian Wedding," ARC 33/02152; "150 Miles of Pipe Lines," ARC 33/02153, and "A Persian Bazaar," ARC 33/02154.

${ }^{609}$ The artist commissioned for the project was Christopher Clark, a "Black \& White Man" known for depicting news events and general interest subjects for British magazines and newspapers during the interwar years. Clark's work was published frequently in the Illustrated London News, Graphic, and the Sphere. F. Mercer and W. Gaunt, Modern Publicity: Commercial Art Annual (London: The Studio, 1932). 
The "Persian Series" rendered a portrait of 1920s Persia as a ruggedly inhospitable country, devoid of modern culture, and staggeringly far from the civilized urban spaces where Britons consumed oil. BP's story of oil began in the ancient period, when Zoroastrians in south western Persia used petroleum in their religious ceremonies. The word "ancient" is used to describe Persia thirteen times in the "Persian Series," making it one of the most frequently-used words in the corpus. Over the course of the series, readers learned of the slow deterioration of Persian civilization, and the region's transition from a richly productive and bustling hub of activity to an arid and empty wilderness. According to one advertisement, the "early glory of Persia was succeeded by centuries of inactivity and depression," suggesting that contemporary Persia and the people who lived there had remained static and unchanging for thousands of years. ${ }^{610} \mathrm{As}$ another advertisement confirmed to British readers with more than a hint of satisfaction and superiority, the highpoint of Persian culture had crested, eclipsed by more powerful, more modern oil-burning empires: "Gone are the captains and kings. Their citadels are crumbled to dust." ${ }^{11}$ Through these stories of rise and decline, BP created an imagined geography of oil in which the vast natural treasures of mysterious Persia were unlocked by modern science and technology for the benefit of the British motorist.

\footnotetext{
610 "The Glories of Ancient Persia," Tatler, 6 May 1925, 97. Similar representations of stagnant and inactive Persian landscapes were common in the contemporary oil literature. An article published in the Sphere magazine in 1914 described the Persian Gulf as "that strange district where modernity jostles against a people living a life of simplicity as led by Father Abraham." Sphere, 19 December 1914, 12. An article published in the Naft magazine in 1925 described the oilfields of Persia as "regions rarely frequented by Europeans. There were no industries in the true sense of the word. Except in the few parts where agriculture was possible, and was practiced in a primitive way, the inhabitants of these regions led a nomadic and often precarious existence, and living conditions had not, in all probability, changed appreciably since the time of Darius." "Visit to Khuzistan of H.H. The Sirdar of Sipah," Naft 1, no. 4 (April 1925): 3-4.

611 "Petroleum as a Weapon," Bystander, 17 June 1925, 69.
} 
The advertisements were saturated with the theme of otherness, which served to unify all twelve of the documents. For example, in the artwork featured in "Transporting Pipe Line in Persia," two local workers were shown directing a team of donkeys along a narrow mountain footpath. ${ }^{612}$ [Figure 14]. The pack animals were laden with sections of oil pipeline together with sacks of supplies and other gear. At the edge of the path, just inches from the bare feet of the workers, the mountain plunged steeply into a black abyss, suggesting to the reader that even walking through this landscape was dangerous and potentially deadly. Another mountain scene was depicted in the artwork of "150 Miles of Pipe Lines," in which several dozen local Persian workers and pack animals laboured to assemble pipeline sections at the bottom of a rubble-strewn valley, accompanied by a handful of British overseers, dressed in white. ${ }^{613}$ [Figure 15]. In this dramatic scene, the workers appeared as tiny figures barely recognizable against the towering black mountains that dominated the image; their craggy peaks casting forbidding shadows upon the labourers. The story conveyed in this advertisement was that Persian landscapes were savage, dangerous, and almost extra-terrestrial in nature, especially in comparison to the clean, white figures of the British overseers. As the text of "The Petroleum Beacon" warned readers, the mountains of south west Persia "loomed" over all who dared trespass there, as "mysterious and menacing." ${ }^{14}$ [Figure 16].

A theme presented in the "Persian Series" was one of challenging topographies, specifically empty landscapes. As several advertisements reminded readers, Persia was a

612 "Transporting Pipe Line in Persia," Sphere, 16 May 1925, 55.

613 "150 Miles of Pipe Lines," Illustrated London News, 25 July 1925, 46.

614 “The Petroleum Beacon," Illustrated Sporting and Dramatic News, 2 May 1925, 41. 
"barren country," comprised of "barren wastes" and "desolate and barren valleys." ${ }^{\prime \prime 15}$ In this distant wasteland, the series recounted, a "small body of British pioneers" had struggled against all odds to establish a colony of oil for the British Empire. ${ }^{616}$ William Knox D'Arcy, the founding father of APOC, was frequently invoked as a symbol of the contest between intrepid British explorers and the Persian mountains (despite the fact that he had never set foot in the country). In "Petroleum as a Weapon," readers learned of the "great English oil-pioneer," and the "desert plains, deep gorges and mountain passes" with which his team of geologists contended. ${ }^{617}$ To even the most experienced and intrepid British adventurers, Persia offered nothing but "difficulties innumerable," including "privation and hardship, and often serious danger." ${ }^{18}$ The depiction of Persia in the advertisements reflected broader contemporary attitudes toward the country and its natural resources. In their 1924 study of British and American oil companies, S. Cooke and E. Davenport associated Persian oilfields with "rugged hills, lack of roads or railways, an exacting climate, poor water [and]...wild Baktiari tribesmen." ${ }^{19}$ The daredevil, Charles Brading, described his motorcar tour across Persia as an "orgy of mudlarking" in a "seething mass of black squelchy mud," while an article published in the Naft magazine in 1926 framed APOC's Persian oilfields as a "desolate, rocky region, entirely devoid of any of the resources of civilization...sparsely inhabited by a few

615 "Transporting Pipe Line in Persia," Graphic, 16 May 1925, 43; "150 Miles of Pipe Lines," Tatler, 1 July 1925, 43; "The Tomb of Khusru Pharviz," Illustrated London News, 23 May 1925, 35.

616 "The Glories of Ancient Persia," Sphere, 9 May 1925, 43.

617 "Petroleum as a Weapon," Bystander, 17 June 1925, 69; Illustrated London News, 11 July 1925, 81. Stories about D'Arcy's early twentieth-century exploits are also presented in "A Persian Wedding," Illustrated London News, 18 July 1925, 37.

618 "Transporting Pipe Line in Persia," Sphere, 16 May 1925, 55; "Petroleum as a Weapon," Tatler, 17 June $1925,73$.

${ }^{619}$ S. Cooke and E. Davenport, The Oil Trusts and Anglo-American Relations (New York: Macmillan, 1924): 12, 239. 
tribesmen...[with] no other material resources than oil." ${ }^{620}$ Writing of his visit to Persia in 1927, the British chemist, Jocelyn Thorpe, recalled "dark and inhospitable" scenes, in which unpredictable rivers cut through the "blackness of the uninhabited desert." 621

The "Persian Series" represented British spaces of oil consumption as irreconcilably different from the Persian geographies from which oil was extracted. The former were presented as bustling hubs of industrial and commercial activity. British consumers of oil products were characterized as superior and inherently more modern than Persians, capable of bringing to bear the "miracles of modern British industry" to the challenging landscapes that harbored "unlimited supplies" of oil. ${ }^{622}$ Equipped with a privileged knowledge of Persian geography, and employing a vast arsenal of advanced oil technologies, BP claimed to have bridged "the great gulf of the centuries" that separated the ancient world, in which oil was used for dubious medicinal practices and tribal rituals, and the modern world, in which oil was consumed as 'BP' motor spirits. ${ }^{623}$ In making these spatial and temporal connections, the company claimed to have brought to all "not the prosperity...won by the sword in distant days, but that which is based on a genuine contribution to the welfare and needs of the world."624 This apparently benevolent extraction of oil was something of which British motorists could be rightfully proud, the advertisements asserted, for it was "part of the romance of modern industry that the great

\footnotetext{
${ }^{620}$ C. Brading, "The Floods in Persia," Naft 1, no. 1 (July 1924): 10; H. McIntyre, "The First Persian PipeLine," Naft 2, no. 6 (November 1926): 7.

${ }^{621}$ J. Thorpe, "Review: J. W. Williamson, In a Persian Oil Field," Nature (3 December 1927): 799. 622 "A Temple of the Fire Worshippers," Illustrated London News, 25 April 1925, 763; "The Glories of Ancient Persia," Sphere, 9 May 1925, 43; "Transporting Pipe Line in Persia," Graphic, 16 May 1925, 43; "When Petroleum was used as Cement," Tatler, 3 June 1925, 63; "A Persian Wedding," Illustrated Sporting and Dramatic News, 15 August 1925, 49.

623 "Transporting Pipe Line in Persia," Graphic, 16 May 1925, 43; "Ferry Boats of the Tigris," Illustrated Sporting and Dramatic News, 13 June 1925, 53.

624 "The Glories of Ancient Persia," Illustrated London News, 9 May 1925, 50.
} 
subterranean sources of petroleum, feeding the oil-springs from which the Arab skimmed his pitch, should to-day furnish the British motorist with the fuel for his car." ${ }^{\prime 625}$

The "Persian Series" advertisements offer historians portholes through which to view the ways that BP imagined the world of oil, and how the company wanted consumers to interpret the multifaceted implications of consuming motor spirits. The advertisements did much more than simply convey product information and increase brand awareness. Although at first glance the "Persian Series" appears to offer a broad spectrum of information about Persian history, culture, and geography, a closer reading reveals that the images and narratives employed by BP actually strove to render Persia as a wild landscape that was empty of life and culture, and therefore ripe for exploitation. The advertisements transformed southwestern Persia into a resource supply site from which companies like APOC and BP were entitled to extract oil on behalf of the British motorist.

625 “The Petroleum Beacon," Sphere, 2 May 1925, 43. 


\section{Figure 14: "Transporting Pipe Line in Persia"}

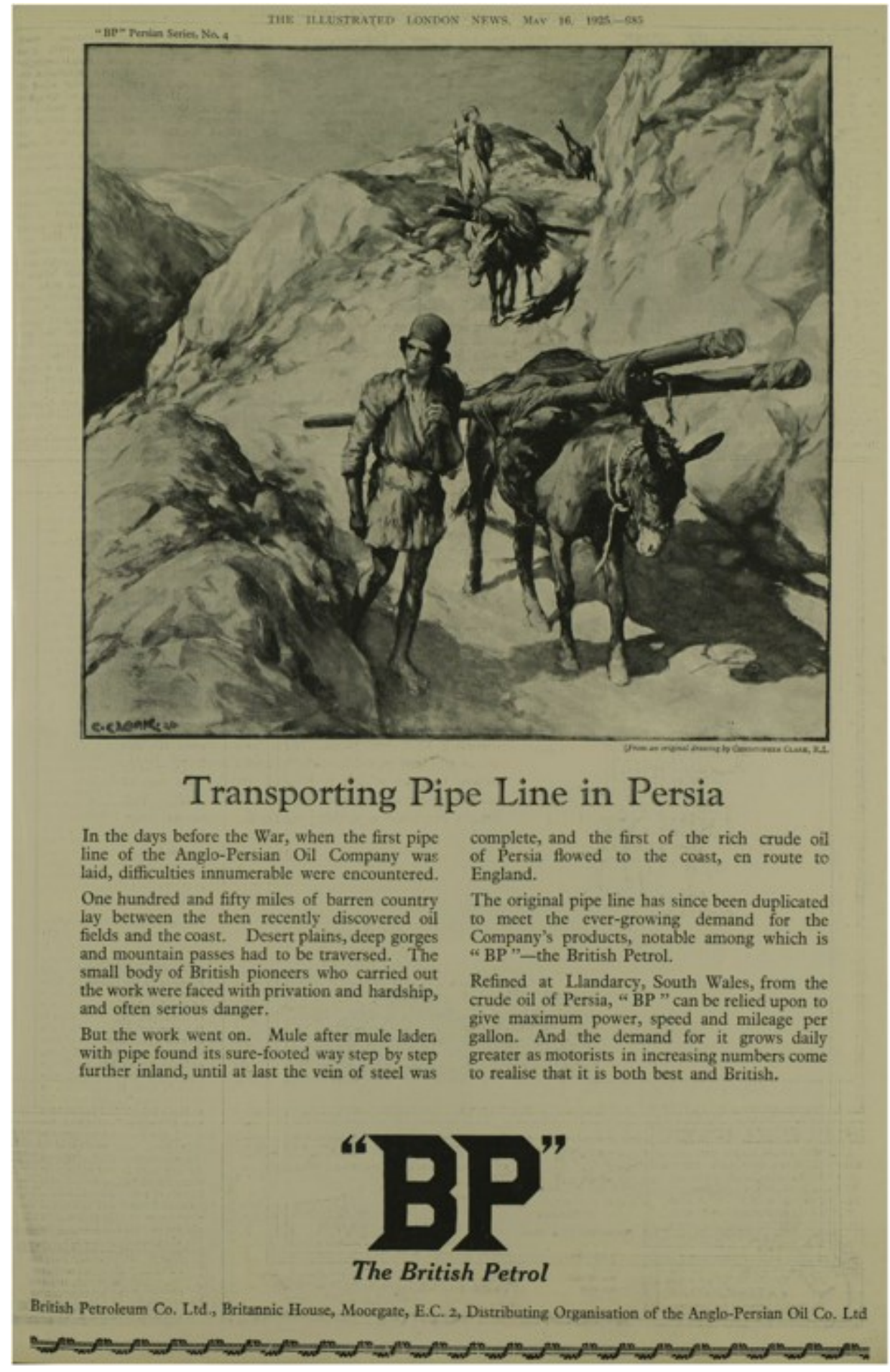

Illustrated London News, 18 May 1925. 
Figure 15: "150 Miles of Pipe Lines"

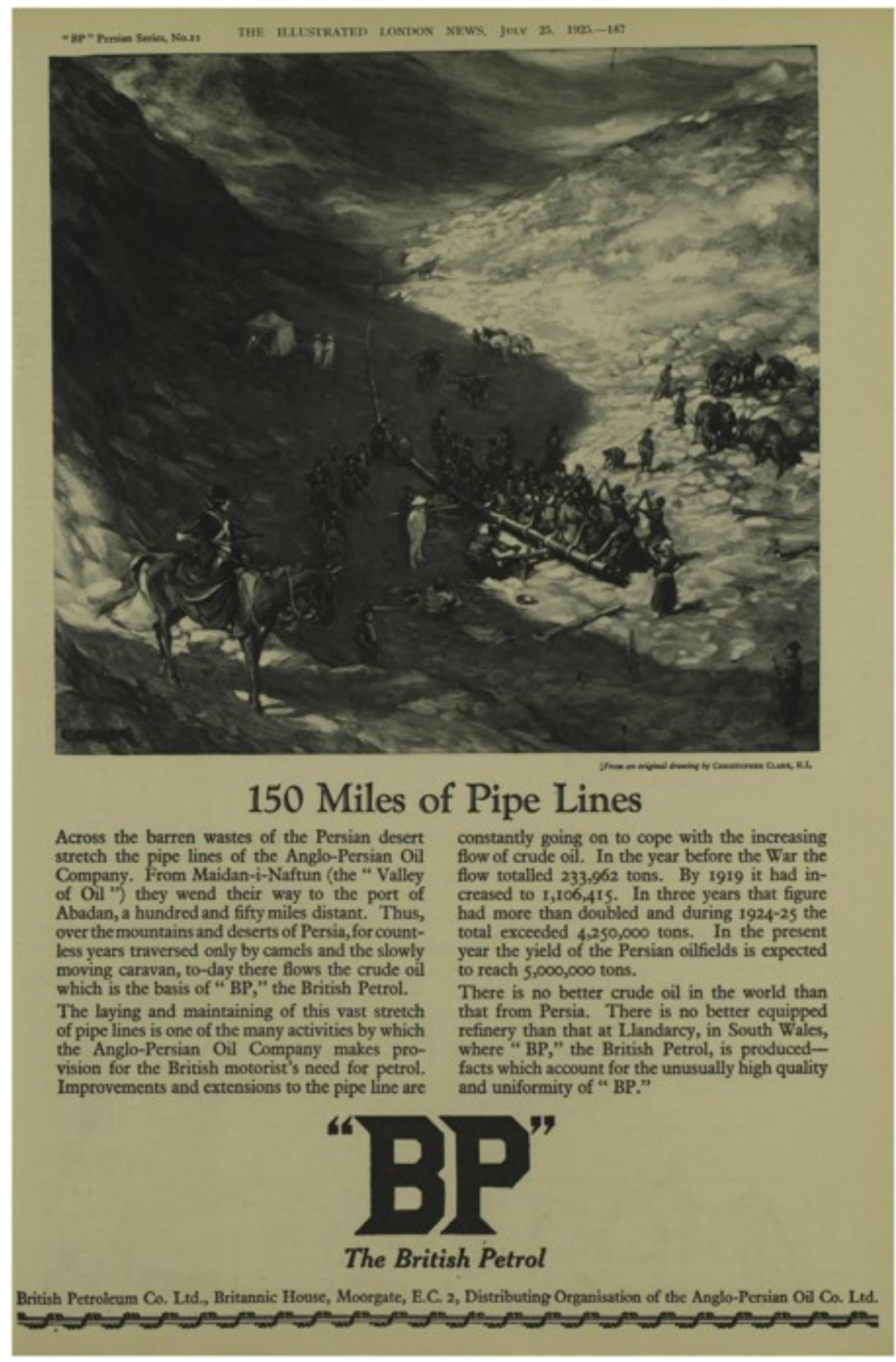

Illustrated London News, 25 July 1925. 


\section{Figure 16: "The Petroleum Beacon"}

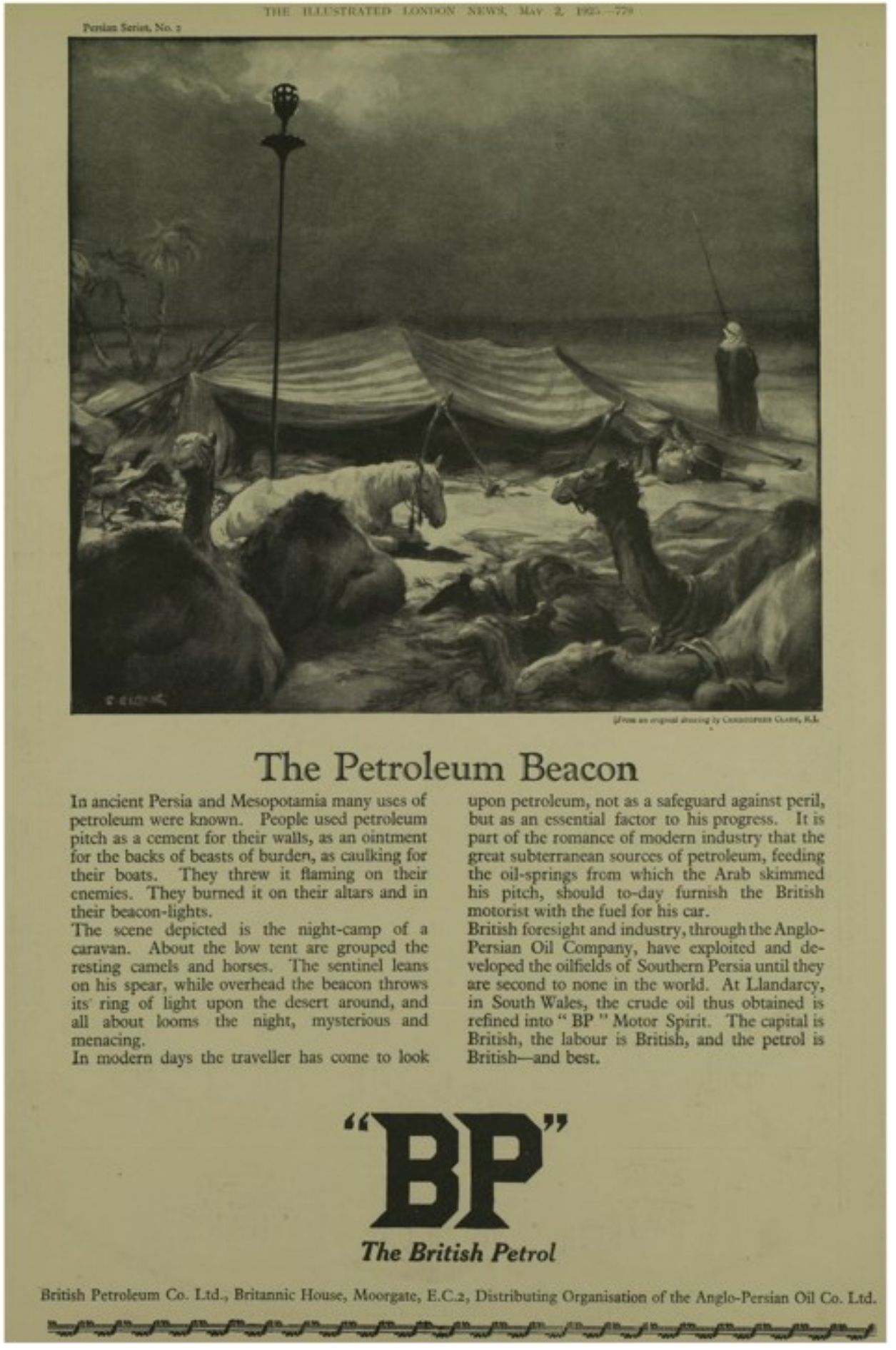

Illustrated London News, 2 May 1925. 
The "Persian Series" represented the most elaborate print advertising campaign to date for BP. The company undertook several different measures to market the advertisements beyond the pages of British newspapers and magazines. In July 1925, in the lobby of Britannic House, the company's recently-completed corporate headquarters in London, BP staged an exhibition of Christopher Clark's "Persian Series" for the Board of Directors. According to Braithwaite, who organized the event, the exhibition was conceived as a means "of illustrating to the Board the extent of the Company's various forms of advertisements. ${ }^{\prime 626}$ The advertisements were presented to a variety of public audiences during this period. The collection was published in a large, 12 " x 14" folio, which was renamed In the Land of the Shah and made available upon request. ${ }^{627}$

This publicity effort appears to have been entirely successful. The editors of the British Medical Journal acquired a copy of the publication, which they applauded for its presentation of "life in ancient Persia and primitive Persia of to-day," and for providing motorists with "the story of the petroleum before it becomes the 'B.P.' petrol." ${ }^{628}$ In its review of the folio, the Illustrated Sporting and Dramatic News reported that Christopher Clark's "splendid reproductions" conveyed information about Persia and BP motor spirits "in a most artistic yet picturesque form." ${ }^{29}$ The Western Gazette, of South Somerset, recommended its readers apply for copies of BP's publication, claiming it offered

\footnotetext{
626 "Sale of Products," $161^{\text {st }}$ Meeting of the Board, 22 July 1925. Christopher Clark's artwork was also published in L. Lockhart, "The Oil of Iraq: An Historical Outline," Naft 1, no. 6 (October 1925): 14. Three of Clark's pieces were displayed in a BP exhibit presented at the Geneva Motor Show in 1931, which was judged by a local newspaper to be "the most decorative and attractive of any erected." "BP' at the Geneva Motor Show," Naft 7, no. 3 (May 1931): 30-31.

${ }^{627}$ In the Land of the Shah: Being a Series of Announcements Issued by the British Petroleum Co., Ltd. (London: Eyre \& Spottiswoode, 1925); Commercial Motor, 17 November 1925. It is unclear whether BP charged a fee for the volume.

628 "Persian Oil," British Medical Journal, 28 November 1925, 1040.

629 "Persia: Ancient and Modern," Illustrated Sporting and Dramatic News, 28 November 1925, 62.
} 
"striking restorations of ancient Persian life and architecture, as well as scenes of modern life in the country through which the pipe lines of [APOC] are laid." ${ }^{630}$ The Aberdeen Press and Journal congratulated BP on producing a "beautifully illustrated" account of the "fascinating history of Persia and Mesopotamia," which at the same time "caught the atmosphere" of contemporary life in the age of oil. "There are some wonderful desert pictures," the article promised, which clashed with the "modern and occidental" stories told about the refining and eventual consumption of oil. ${ }^{631}$

The Persian Khan: British Petroleum and the British Empire Exhibition, 1924-1925

In February 1924, BP began preparations for its largest and most elaborate motor spirit marketing campaign of the 1920s - the Persian Khan exhibit, constructed for the British Empire Exhibitions [BEE] of 1924 and $1925 .{ }^{632}$ The Khan was the capstone achievement of Braithwaite's restructured Advertising Department, and the culmination of BP's Persian-inspired messaging strategy. The installation took the form of a large Khan, or caravanserai, the traditional structure used by travellers to rest and recover as they travelled across the Persian desert. Inside the Khan, visitors learned about Persia and its oil resources by engaging with BP interpreters, and a series of marketing initiatives, including illustrated pamphlets, display cases filled with information and artefacts, and

630 "In the Land of the Shah," Western Gazette, 20 November 1925, 16.

631 "B.P Portfolio," Aberdeen Press and Journal, 18 November 1925, 2.

632 "Motor Licences," $155^{\text {th }}$ Meeting of the Board, 21 January 1925. Planning for the Khan exhibit began in late 1923, when BP Board Members approved a budget of $£ 6,000$. "Ministry of Transport on Petrol Service Pumps," $137^{\text {th }}$ Meeting of the Board, 24 September 1923; "Advertising," $142^{\text {nd }}$ Meeting of the Board, 18 December 1923; "Wembley Exhibit," $156^{\text {th }}$ Meeting of the Board, 18 February 1925; "British Empire Exhibit," $157^{\text {th }}$ Meeting of the Board, 25 March 1925. 
artwork displaying the scenes depicted in the "Persian Series." ${ }^{633}$ The Khan was ideally located at the BEE, placed along the main pedestrian walkway, in between the Canada and India Pavilions, and directly in front of His Majesty's Government's Pavilion.

BP's Persian Khan exhibit was an oil spectacle in every way; bold, eye-catching, and extravagant. Yet, despite its prominence at the BEE, the exhibit was subsequently practically written out of the official histories of the exhibition. There are no mentions of the Khan in the 115-page Official Guide to the BEE, nor any in the brochure for the grand opening ceremony or the photographic souvenir booklet. ${ }^{634}$ The Khan does not appear on the official map for the BEE, and the location of the exhibit is instead left empty. [Figure 17]. Another odd example of erasure can be found in a special booklet of 85 pages, published by the Illustrated London News in May of 1924, in which the only reference to the Persian Khan appears in an advertisement placed by BP on page $73 .{ }^{635}$ The invisibility of the company's Persian-inspired exhibit has continued to be a feature of the secondary literature on the BEE. Anne Clendinning's article on the exhibition, published in 2006, contains no discussion of the BP Khan, despite the author's focus on the symbolic architecture of several national pavilions. ${ }^{636}$ In Alexander Geppert's Fleeting Cities (2010), the BEE is examined through the lens of imperialism and cross-cultural

\footnotetext{
${ }^{633}$ According to UNESCO, Persian caravanserais are "one of the amazing architectural structures in the history of architecture, which played the role of connecting bridges between civilizations and societies." Retrieved from: www.whc.unesco.org/en/tentativelists/6197.

${ }^{634}$ British Empire Exhibition, Official Map (London: Dobson, Molle \& Co, 1924); A Souvenir of the British Empire Exhibition, Wembley (London: Fleetway, 1924); Official Guide to the British Empire Exhibition (London: Fleetway, 1924); Opening Ceremony by H.M. the King accompanied by H.M. the Queen (London: Fleetway, 1925).

635 "Special Issue: Wembley," Illustrated London News, 24 May 1924, 1-85.

${ }^{636}$ A. Clendinning, "Exhibiting a Nation: Canada at the British Empire Exhibition, 1924-1925," Social History 39, no. 77 (2006): 79-107.
} 
contact, yet here too there are no references to the Persian Khan exhibit. ${ }^{637}$ Mark Crinson references the exhibit in his article on APOC oil architecture during the early twentieth century, in which he describes the structure as one of the company's "best-known public architectural expressions in England," but he cites no primary sources and provides no further analysis of the exhibit or its contents. ${ }^{638}$

Furthermore, as the most elaborate form of motor spirit marketing undertaken by the company during its formative years, it is surprising that BP's Persian Khan exhibit has attracted little attention from energy historians. In Ferrier's History of the British Petroleum Company (1982), the Khan receives only the briefest mention, accommodated as it was in a larger discussion of BP's interwar marketing strategy. "Publicity and advertising," Ferrier wrote, "had already been used...the most spectacular example was the Company's participation in the Wembley Exhibition of 1924." ${ }^{639}$ Ferrier makes no use of primary sources related to the exhibit, however, and he neglects to inform the reader that the BEE (and the Persian Khan) continued for a second season in 1925. In Ferrier's 1986 article on the BP motor spirit marketing campaigns of the interwar period, the author recognizes BP's involvement in the "great industrial exhibitions of Olympia and Wembley," but adds no further comment and his sources of evidence remain a mystery. ${ }^{640}$

\footnotetext{
${ }^{637}$ A. Geppert, Fleeting Cities: Imperial Expositions in Fin-de-Siècle Europe (New York: Palgrave Macmillan, 2010).

${ }^{638}$ M. Crinson, "Abadan: Planning and Architecture Under the Anglo-Iranian Oil Company," Planning Perspectives 12, no. 3 (1997): 349. The BP Khan is also absent from M. Crinson, Empire Building: Victorian Architecture and Orientalism (London: Routledge, 1996); M. Crinson, Modern Architecture and the End of Empire (Aldershot: Ashgate, 2003); M. Crinson, "Imperial Modernism," in Alex Bremner (ed.), Architecture and Urbanism in the British Empire (Oxford: Oxford University Press, 2016).

${ }^{639}$ Ferrier, 1982, 339.

${ }^{640}$ Ferrier, 1986, 29-51.
} 
The largest, costliest, and most elaborate motor spirit marketing activity undertaken by BP during the company's formative years remains largely forgotten. This is important to energy historians because, as the remainder of this chapter demonstrates, the exhibit offers a trove of information about BP's overall marketing strategy and the vision of oil it sought to instil in the mind of British motorists. BP's Persian Khan exhibit provides a case study for enriching scholarly understandings of how oil was imagined in mid-1920s Britain, and a useful lens through which to view the broader development of British petroculture during the period.

Figure 17: Official Map of British Empire Exhibition, 1924, with location of BP's Persian Khan exhibit outlined in red

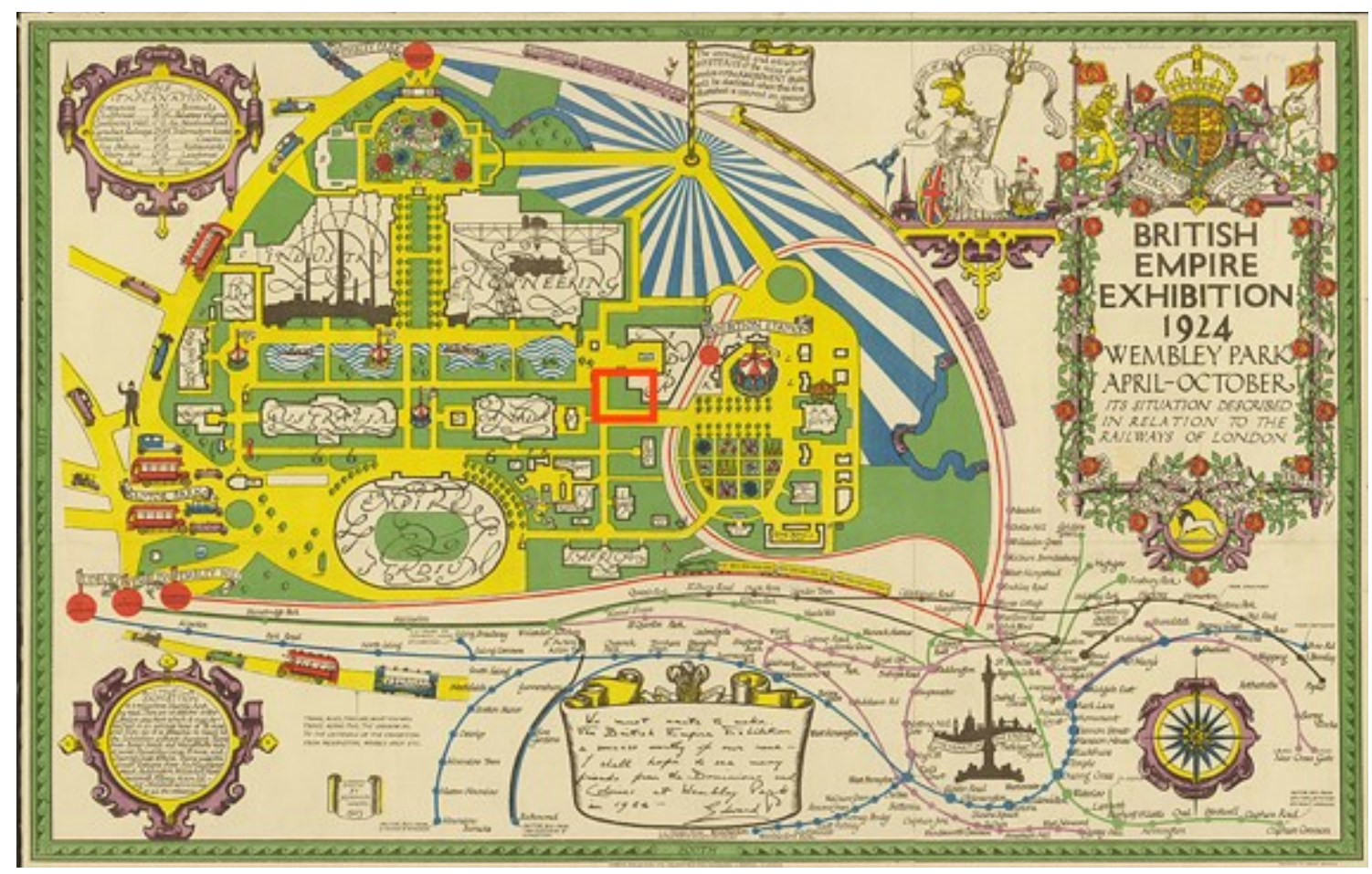

British Empire Exhibition, Official Map, 1924. 
The British Empire Exhibition was one of the largest public events held in Britain during the $1920 \mathrm{~s} .{ }^{641}$ Staged on a 220 -acre plot of land in the north-London suburb of Wembley, the BEE was designed to showcase the scientific, technological, and commercial achievements of the British Empire. ${ }^{642}$ The architectural projects undertaken at the BEE were defined by superlatives: the Palace of Engineering was the largest concrete building in the world, and the Wembley Stadium the largest sports arena in existence. ${ }^{643}$ As Anne Clendinning has written, the BEE was "[p]art trade fair and part theme park," featuring dozens of pavilions and exhibition halls, as well as restaurants, cinemas, an amusement park, and an artificial lake equipped with gondolas for hire. The 24 kilometres of streets that connected the exhibition halls were designed to resemble the cross of St. George, and they carried names chosen by Rudyard Kipling, the poet of Empire: Union Approach, Atlantic Slope, Dominion Way. ${ }^{644}$ This extravagant spectacle of Empire opened on a national holiday, St. George's Day, 23 April $1924 .{ }^{645}$

${ }^{641}$ Planning for the British Empire Exhibition began in 1919. Despite an attendance of 17 million people, the 1924 BEE lost more than $£ 600,000$. In an attempt to recuperate these losses, a second British Empire Exhibition was organized for 1925. This iteration was, in essence and in spirit, nearly identical to the BEE held in 1924. It carried the same name, took place on the same site, and hosted similar exhibits and pavilions. The event was marked by the absence of India and Burma, which were unable to marshal the funds necessary for a second appearance. The $1925 \mathrm{BEE}$ was even less successful than the first, with attendance much lower than the anticipated 30 million. The exhibition concluded with the speech, delivered by the Duke of York in October 1925, recently made familiar to another generation by the film, The King's Speech (2010). "A Second Year of the Exhibition," United Empire 10 (1924): 570; T. Clarke, "British Empire Exhibition: Second Phase," $19^{\text {th }}$ Century (February 1925): 175; "The New Wembley," Saturday Review, 9 May 1925, 480; "Reopening of the British Empire Exhibition in Wembley," Travel, June 1925, 41; Geppert, 2010, 145-146.

${ }^{642}$ G. Lawrence (ed.), Official Guide to the British Empire Exhibition (London: Fleetway, 1924): 7.

${ }^{643}$ Lawrence, 37; A. Geppert. Fleeting Cities: Imperial Expositions in fin-de-Siècle Europe (London: Palgrave Macmillan, 2010): 146.

${ }^{644}$ A. Clendinning, "Exhibiting a Nation: Canada at the British Empire Exhibition, 1924-1925," Social History 39, no. 77 (2006): 79-107.

645 “St. George's Day Lessons," The Times, 23 April 1924, 11; “St. George's Day in the United Kingdom," 2016. Retrieved from: www.timeanddate.com/holidays/uk/st-george-day. 
The BEE was an ideal venue for BP to promote its oil products. According to historian J. M. MacKenzie, it was "the greatest of all the imperial exhibitions - in area, cost, extent of participation, and, probably, popular impact." ${ }^{\prime 46}$ The overall attendance at the 150-day event amounted to more than seventeen million people, which from a strictly commercial standpoint offered BP a massive audience with which to engage. ${ }^{647}$ In addition, the BEE showcased a range of modern new technologies, particularly those related to communication and transportation. ${ }^{648}$ Oil-powered vehicles were featured prominently at the exhibition, especially at the Motor and Cycle Section, where visitors could inspect "every type of car and cycle, as well as tractors, marine and aero engines, and steam and electric motor vehicles." ${ }^{949}$

BP also benefited from the extensive and widespread publicity that attended the BEE. The images and stories used to describe the exhibition in the official literature and associated press reportage fitted seamlessly into the narratives being developed in BP's contemporary print advertising campaigns. The Official Guide was saturated with notions of cultural collision, modern science and technology, and industrial progress. In this "Empire City," it proclaimed, one could see "the latest marvels of Western science" alongside the "splendours of the markets of the East and the simple fairs of primitive peoples. ${ }^{" 650}$ According to a promotional booklet published by the Illustrated London

\footnotetext{
${ }^{646}$ J. M. MacKenzie, Propaganda and Empire: The Manipulation of British Public Opinion, 1880-1960 (Manchester: Manchester University Press, 1984): 108.

${ }^{647}$ Geppert, 2010, 146. According to Geppert, the exact attendance figure was 17,403,267.

${ }^{648}$ Clendinning, 2006, 79-107. A feature of the opening ceremony of the 1924 BEE was a telegraph sent to every corner of the empire, with responses arriving 80 seconds later. King George V's proclamation over the BBC airwaves ("I declare this exhibition open") was the first message by a head of state ever transmitted on live radio. A fleet of 200 electric buses provided transportation for visitors, as did a number of private cars for hire, which used a novel rail system to direct guests to the different pavilions.

${ }^{649}$ Official Guide to the British Empire Exhibition, 1924, 51; British Empire Exhibition, Official Map (London: Dobson, Molle \& Co, 1924).

${ }^{650}$ Lawrence, Official Guide to the British Empire Exhibition, 1924, 22.
} 
News in May 1924, the BEE offered visitors a chance to experience the "juxtaposition of disjointed and diverse civilisations and arts and architectures." ${ }^{651}$ Like BP's Persian Khan exhibit, the BEE was "meant primarily to be a spectacle," an event designed to catch the attention of wide audiences and to shape their thinking about the world. ${ }^{652}$ As the Illustrated London News explained in July 1924, the BEE was "itself, in a sense, the greatest advertisement ever created. ${ }^{9653}$

BP capitalized on the marketing opportunities presented by the BEE. ${ }^{654}$ The Persian Khan exhibit took the form of a square, two-storey building designed in classical Persian architectural style, defined by simple, block-like forms, crenelated rooflines, and arched entryways and windows. At each corner of the building were placed four slender minarets of approximately 40 feet in height, which featured a gallery at the three-quarter mark and a pointed dome on top. Three high-arched doorways marked the western, southern, and eastern facades, each of which was set in an elaborately-decorated recess. These portal-like openings were vaulted in the decorative muqarnas style common to Islamic architecture, and were flanked by two arched windows, also set in recesses and filled with an intricately-patterned screen that obstructed the view to the inside. ${ }^{655}$ Perhaps the most spectacular feature of the exhibit's exterior was its brightly-coloured

${ }^{651}$ G. Chesterton, "Our Notebook,” Illustrated London News, 24 May 1924, 930.

652 "Special Issue: Wembley," Illustrated London News, 24 May 1924, 39.

653 "Special Issue: Wembley," Illustrated London News, 24 May 1924, 1-85.

${ }^{654}$ Other British energy companies entered exhibits at the BEE. The coal industry constructed a full-scale mineshaft that brought tourists down into a model mine, where they could view pit ponies, miners, and samples of coal. The British gas industry constructed an exhibit with rooms decorated to show the "Seven Ages of Woman [sic]." "The Spirit of Coal Offers Service to the Empire," Illustrated London News, 24 May 1924, 925; "The Lighter Side of Wembley," Illustrated London News, 24 May 1924, 974.

${ }^{655}$ The muqarnas is a common feature of Islamic architecture. Developed during the $11^{\text {th }}$ century, it refers to a form of three-dimensional, stalactite vaulting present in the doorways and windows of both religious and secular buildings. D. Swinford, "The Muqarnas: a Key Component of Islamic Architecture," in N. Schlager and J. Lauer (eds.), Science and Its Times (Gale Virtual Reference Library, 2001): 216-218. 
walls - adorned in yellow, green, and blue tiles arranged in tessellated, and distinctly

Persian, geometric patterns. A BP motor spirit delivery wagon, branded with the company's logo, was permanently stationed in front of the Khan - except when twice daily the wagon was pulled around the exhibition grounds, supplying fuel oil to the Palace of Engineering and Palace of Industry buildings. ${ }^{656}$

The Persian Khan exhibit was the ultimate expression of outdoor advertising. It caught the eye of consumers and drew them in to learn more about BP and its products. The narratives of ancient Persia were continued inside the exhibit, where the messaging techniques developed in BP's print advertising campaigns were utilized to full effect. Upon arrival, visitors were approached by BP sales representatives and exhibit interpreters. They handed out postcards featuring an artist's rendition of the Khan, and guided visitors through the exhibit. ${ }^{657}$ [Figure 18]. The visitor's experience was centred upon a series of educational display cases, which were intended to be viewed in sequence. Four cases were tucked into ornately decorated vaulted alcoves, located in the centre of each interior wall. Inside the showcases were samples of BP's refined oil products, examples of kerosene lamps and other oil-burning technologies, and a variety of photographs of APOC and BP commercial activities in Persia and Britain. ${ }^{658}$

The most commanding feature of the interior of the Khan was a large, ten-sided mahogany showcase, placed in the centre of the exhibition space and clearly visible from

656 “Oil at Wembley,” Hull Daily Mail, 20 March 1924, 3; “The Great 'B.P.' at Wembley,” Flight, 5 June 1924, 374 .

${ }^{657}$ Anglo-Persian Oil Company, Wembley (postcard), 1924. BP Archives, ARC 206530; ““B.P.' at Wembley," Aberdeen Press and Journal, 31 May 1924, 4.

${ }^{658}$ According to the Oxford Dictionary of Architecture, the mihrab is a "semicircular, polygonal, or rectangular niche or recess, chamber, or slab in the qibla wall of a mosque, often elaborated decorated, indicating the direction of Mecca... Openings to mihrabs may be flanked by columns from the capitals of which spring arches, and the hoods of niches may be embellished with muqarnas." J. Stevens and S. Wilson (eds.), Oxford Dictionary of Architecture (Oxford: Oxford University Press, 2015). 
all angles. The display featured back-lit illustrations, photographs, and dioramas that told the story of how BP products arrived at the pointed nozzle that filled up the motorist's tank or 2-gallon BP can. According to the Naft magazine, the scenes presented in the showcase were arranged "in proper sequence, so that a visitor walking around the exhibit sees a complete pictorial representation of the course of oil from the wells in Persia to its delivery to the customer as 'BP' Motor Spirit." ${ }^{\text {" } 59}$ The windows explained the different processes by which Persian crude oil was transformed into BP motor spirit at APOC's Abadan and Llandarcy refineries, and they showed the dramatic transformations of local landscapes, both in the hard mountains of southwest Persia and the wastelands and bogs near Skewen, South Wales. A series of smaller windows around the top of the showcase depicted various oil fuelled technologies - a tractor working a field, a fleet of BP delivery vehicles, and an open-cockpit race car.

The contents of the showcases told the same story that BP had been developing since its first print advertising campaign of 1919; namely, that modern science and technology had been marshalled in exotic Persia in order to produce a powerful and reliable motor spirit for the pleasure of the British motorist. The showcase design, however, was distinctly Victorian, which had the effect of reaching into the past, while the modern technologies contained inside them produced a sharp entry into the future. To further underscore the transition from the ancient past to the modern future, the interior of the Khan was decorated with large reproductions of the artwork presented in the "Persian Series." ${ }^{660}$ A visit to the Khan exhibit provided guests with a complete portrait of BP's vision of oil and the future.

\footnotetext{
659 “The Company's Exhibit at Wembley," Naft 1, no. 4 (April 1925): 35.
}

660 "The Company's Exhibit at Wembley," Naft 1, no. 4 (April 1925): 35. 
Figure 18: Postcard distributed by BP staff at the Persian Khan exhibit

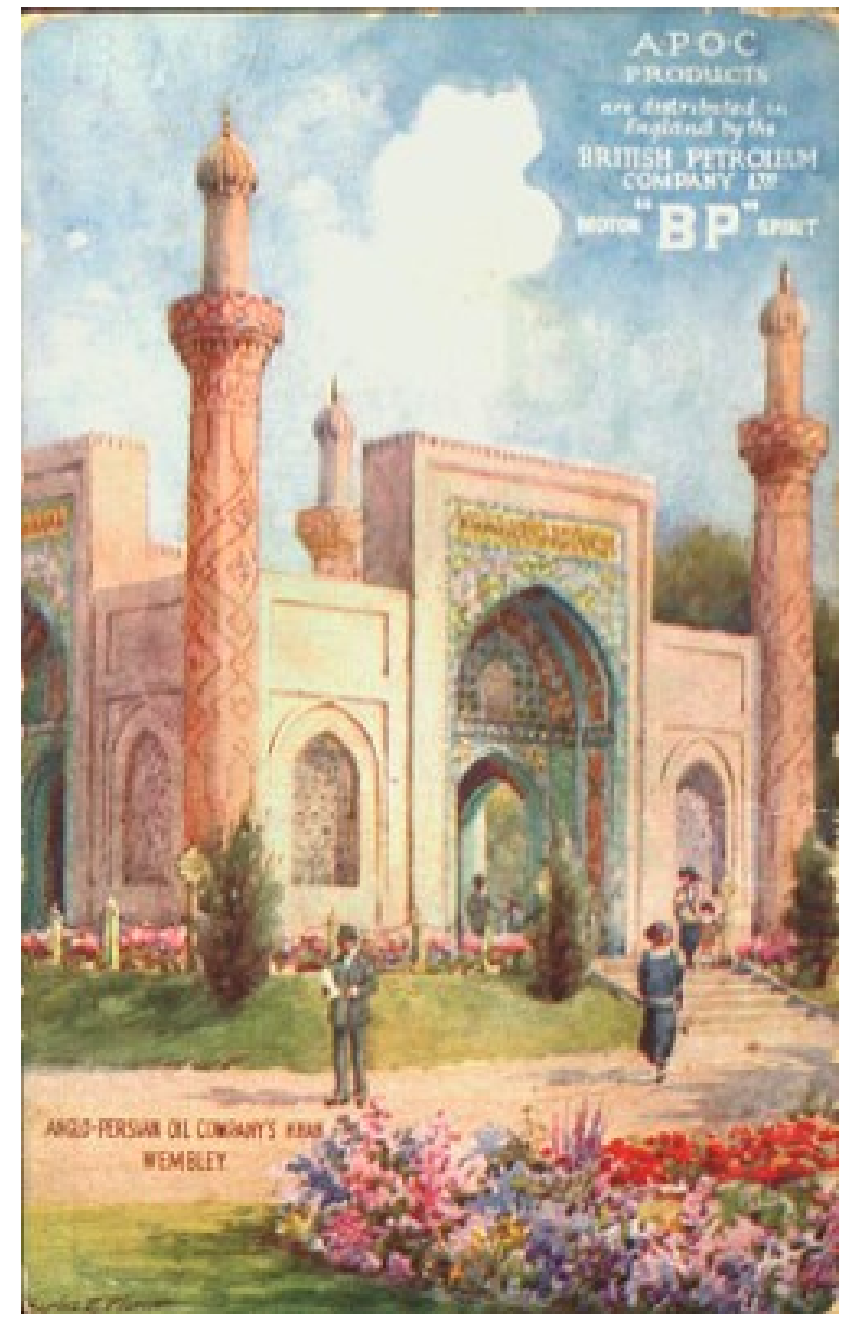

British Petroleum, Wembley (postcard), 1924.

BP hosted several publicity activities at the Persian Khan exhibit, which were intended to communicate the company's messages about ancient Persia and modern oil to targeted audiences. In addition to regular admission visitors, BP invited a number of 
distinguished guests to the Persian Khan exhibit. In July 1924, Sir Charles Greenway, the Chairman of APOC, hosted an exclusive dinner for 81 guests at the Lucullus Restaurant, located on the grounds of the BEE. The dinner brought together major figures in the British and American oil industries, including A.C. Bedford and W.C. Teagle, the Chairman and President, respectively, of Standard Oil New Jersey. Following the meal, the guests were taken on a private tour of the Khan, and a group photograph was taken on the stairs inside one of the high-arched entryways. ${ }^{661}$ During the second iteration of the BEE, in October 1925, BP board members hosted a luncheon at the Lucullus for the Management Committee of the Société Générale des Huiles de Pétrole, BP's sister company in France. ${ }^{62}$ This delegation was also given a private tour of the Khan exhibit, which was led by members of the BP Advertising Department, including Braithwaite, Watts, and Peter Donovan. ${ }^{663}$

The Persian Khan was also promoted among BP and APOC's global workforce of some $60,000 .{ }^{664}$ In July 1924 , the company's staff magazine, the Naft, published an article that described the exhibit and its contents. ${ }^{665}$ The "delicate colouring" of the Khan made it "easily the most beautiful of the smaller buildings of the Exhibition," it was reported, while the mixture of Persian and British architectural styles produced a

\footnotetext{
${ }^{661}$ Invitation Card from the Chairman and Directors of the Anglo-Persian Oil Company, 24 July 1924. BP Archives, ARC 210927; Seating Plan for the Anglo-Persian Oil Company Limited, at the Lucullus Restaurant, Wembley, 24 July 1924. ARC 210928.

${ }^{662}$ Members of the English delegation included Sir Charles Greenway; Sir Arnold T. Wilson; Sir Edmond Slade; Sur Hugh Barnes, and H.B. Heath Eaves. Members of the French delegation included Sir Basil Zaharoff; F. Gorchs-Chacou; P. Houët; M. Carrier; M. Paix; M. Lesieur; P. Lesieur; N. Pietri, and H. Bavière.

663 “A Real Entente Cordiale," Naft 1, no. 3 (January 1925): 10. Donovan led tours of the Llandarcy Refinery on the day of its grand opening.

664 "Drama in Industry," Naft 6, no. 3 (May 1930): 3-4.

665 "The A.P.O.C. at Wembley," Naft 1, no. 1 (July 1924): 25-26.
} 
structure that was both "dignified and attractive." 666 The readers of the Naft learned that the exhibit told the story of Persian oil, which represented "a most romantic and impressive episode in the history of the modern oil industry." It was precisely this storytelling capacity that made the BP Khan "of great benefit to the company, impressing on the popular mind the unique and most important role it plays in the oil resources of the Empire." 667

The largest component of BP's strategy to promote the Persian Khan exhibit took the form of an advertising campaign, launched in British newspapers and magazines during the summer driving seasons of 1924 and 1925. The BEE advertisements shared many similarities with the company's other contemporary advertisements: the communication of information to the reader about a future experience with oil, and the use of images and stories designed to produce an affective reaction. The ads featured drawings and photographs of the Persian Khan exhibit, as well as a section of text that explained what visitors could expect to see upon their arrival at the installation. What makes these ads particularly fascinating is their integration with other elements of BP's motor spirit marketing strategy, and the combining of print advertising, outdoor advertising, and public exhibition techniques into a single campaign.

The first advertisements for the Persian Khan exhibit were published in June 1924, under the series title, "B.P. at Wembley." The ads appeared in numerous newspapers and magazines that the company had used in the past, including the Illustrated London News, Graphic, Tatler, and The Times, and they featured several large

666 "Editorial - The A.P.O.C. at Wembley," Naft 1, no. 1 (July 1924): 25.

667 "Editorial - The A.P.O.C. at Wembley," Naft 1, no. 1 (July 1924): 25. 
drawings and photographs of the Khan exhibit. ${ }^{668} \mathrm{~A}$ visit to the company's "distinctively Persian building," explained one ad published in the Sphere, with its "slender minarets and its blue-and-green tiled doorways," would provide "a reminder of the beauty and ancient splendour of the Land of the Shahs." ${ }^{669}$ Inside the exhibit, the ad continued, visitors could expect to hear stories about the "source of crude oil which is brought to Great Britain," and to learn of the "engineering and chemical skill and the immense business organisation engaged in the task of production, refining, and distribution." The advertisement highlighted the five educational display cases placed throughout the exhibit, and their effectiveness in guiding visitors "through Persia and every phase in the production of the oil from which 'BP,' the British Petrol, is refined."671

Another print advertising campaign was launched for the second BEE held in 1925. BP produced three new ads, under the title "Anglo-Persian Oil Company and 'BP' Motor Spirit at Wembley,” that were published in the same newspapers and magazines as in the previous year. ${ }^{672}$ The title of the series reflected the pivot to Persia initiated by Braithwaite in 1923 and 1924, and the desire of BP to create a closer association between itself and APOC in the mind of the consumer. A second distinguishing feature of the 1925 advertisements was the use of more evocative imagery. An advertisement published in July 1925, for example, included a photograph of the Persian Khan exhibit at night, surrounded by dozens of visitors. The figures were all partially blurred, which gave the impression of movement and the hum of a bustling crowd. There appear to be beams of

\footnotetext{
668 “'BP' at Wembley,” Tatler, 21 May 1924, 79; Sketch, 21 May 1924, 81; The Times, 24 May 1924; Bystander, 11 June 1924, 101; Sphere, 14 June 1924, 39; Illustrated London News, 21 June 1924, 1203. 669 “"BP' at Wembley," Sphere, 31 May 1924, 45. 670 “"BP' at Wembley,” Graphic, 31 May 1924, 35; Bystander, 28 May 1924, 70. 671 “"BP' at Wembley,” Motor Cycle, 12 June 1924.

672 “Anglo-Persian Oil Company and 'BP' Motor Spirit at Wembley,” Times, 8 July 1925, 11; Sketch, 29 July 1925, 42; Illustrated London News, 15 August 1925, 36.
} 
light painted on to the photograph, which emanate from the exhibit's decorated higharched doorway on to the visitors, bathing them in a dull glow. [Figure 19].

The print advertisements published for the 1925 Persian Khan added more details about the information that visitors would receive. "The story of a great national enterprise is told in attractive tableaux," claimed an advertisement published in the Illustrated London News in August 1925. ${ }^{673}$ "The interior of the exhibit was designed to convey an impression of the more important points in the sequence of activities... necessary before 'BP' reaches the motorist." ${ }^{\circ 74}$ An advertisement published in The Times in July focussed on the educational aspects of BP's installation at the BEE, and featured an illustration of a man and woman inspecting the ten-sided mahogany showcase at the centre of the exhibit. ${ }^{675}$ The male figure, dressed in a coat and wearing a hat, points to one of the showcase's backlit panels, which depicted a cross-section diagram of an oil well and drill bit descending through different strata of rock. The female figure, dressed in a coat and wearing a flapper's hat, also gazed intently at the diagram. The text accompanying the image encouraged the reader to visit the Persian Khan so that they, too, could "learn of the great organization that produces 'BP,"” and of the "scientific production methods and up-to-date refinery processes which make 'BP' the best of all motor spirits." ${ }^{\prime 676}$ The most impassioned argument for visiting the Persian Khan exhibit was articulated in a BP advertisement published in the Bystander, Sketch, and Tatler in July and August of 1925:

And when you have visualised the drilling of wells, the pumping of crude oil, the long ocean voyage from the Persian Gulf to the great refinery at Llandarcy -

\footnotetext{
673 "Anglo-Persian Oil Company and 'BP' Motor Spirit at Wembley," Illustrated London News, 15 August $1925,327$.

674 “Anglo-Persian Oil Company and 'BP' Motor Spirit at Wembley," Illustrated Sporting and Dramatic News, 25 July 1925, 58.

675 “Anglo-Persian Oil Company and 'BP' Motor Spirit at Wembley," The Times, 8 July 1925, 11.

676 “Anglo-Persian Oil Company and 'BP' Motor Spirit at Wembley,” The Times, 8 July 1925, 11.
} 
when you have considered some of the intricacies of the organisation which delivers 'BP' to every town and village throughout the country - then you can see the photographs and the story of the men who have achieved fame in the world of motoring, with the aid of this British Petrol. ${ }^{677}$

The passage reveals much about BP's overall advertising strategy for the Persian Khan. The intent was to direct attention towards the exhibit and to encourage readers to consider making a visit. Once there, the purpose of the exhibit was both to educate and to entertain with stories about oil, and to explain the complicated journey from wellhead to the local free dealer garage. The final stage in this process of petro-persuasion would be undertaken by motorists who, with minds swirling with information and ideas about the product being put into their vehicle, would unhesitatingly ask for BP at their next fill-up.

A review of the press coverage associated with the exhibit illustrates the significant impact that the company made at the BEE. Flight magazine published a photograph of the "characteristic and beautiful pavilion," in front of which was parked the company's oil delivery wagon, prominently branded with the letters 'BP.' Inside the Khan, the caption reported, visitors would learn from a series of "interesting and comprehensive" showcases, which showed the "various processes and stages in the manufacture of 'B.P.' motor spirit and other products of the Anglo-Persian Oil Co." ${ }^{678}$ The Illustrated London News also commented on the "romantic story" that was told through the five showcases featured in BP's exhibit, as did the Petroleum Times and Tatler ${ }^{679}$ News of the Persian Khan spread to places far beyond London and southeast

\footnotetext{
677 “Anglo-Persian Oil Company and 'BP' Motor Spirit at Wembley,” Bystander, 29 July 1925, 295; Sketch, 29 July 1925, 186; Tatler, 29 July 1925, i.

678 “The Great 'B.P.' at Wembley," Flight, 5 June 1924, 374.

679 “"B.P.' at Wembley,” Illustrated London News, 7 June 1924, 1093; “The Anglo-Persian Oil Company’s Exhibit at Wembley," Petroleum Times, 24 May 1924, 740; Tatler, 11 June 1924, 68.
} 
England. The Aberdeen Press and Journal wrote in May 1924 that the exhibit "carries the mind back to the beauty and mystery and ancient splendour of Persia." ${ }^{980}$ Through a series of showcases containing "tangible exhibits of machinery and products," the paper explained, BP told the "romantic story" of oil's journey from Persia to Britain. The Persian Khan's collection of artefacts, images, and stories about oil had the effect of producing a "vivid illustration of the extent to which Empire oil now enters into daily life." ${ }^{681}$ In June, the Belfast News Letter reported to its readers that BP's exhibit highlighted the "extraordinary blend of East and West which the history of the company presents," and told visitors the story of "one of the greatest and most successful British commercial enterprises of modern times." ${ }^{982}$

680 ““B.P.' at Wembley,” Aberdeen Press and Journal, 31 May 1924, 4.

681 “"B.P.' at Wembley," Aberdeen Press and Journal, 31 May 1924, 4.

682 “The Anglo-Persian Oil Co. at Wembley,” Belfast News Letter, 4 June 1924, 4. 
Figure 19: "Anglo-Persian Oil Company and 'BP' Motor Spirit at Wembley"

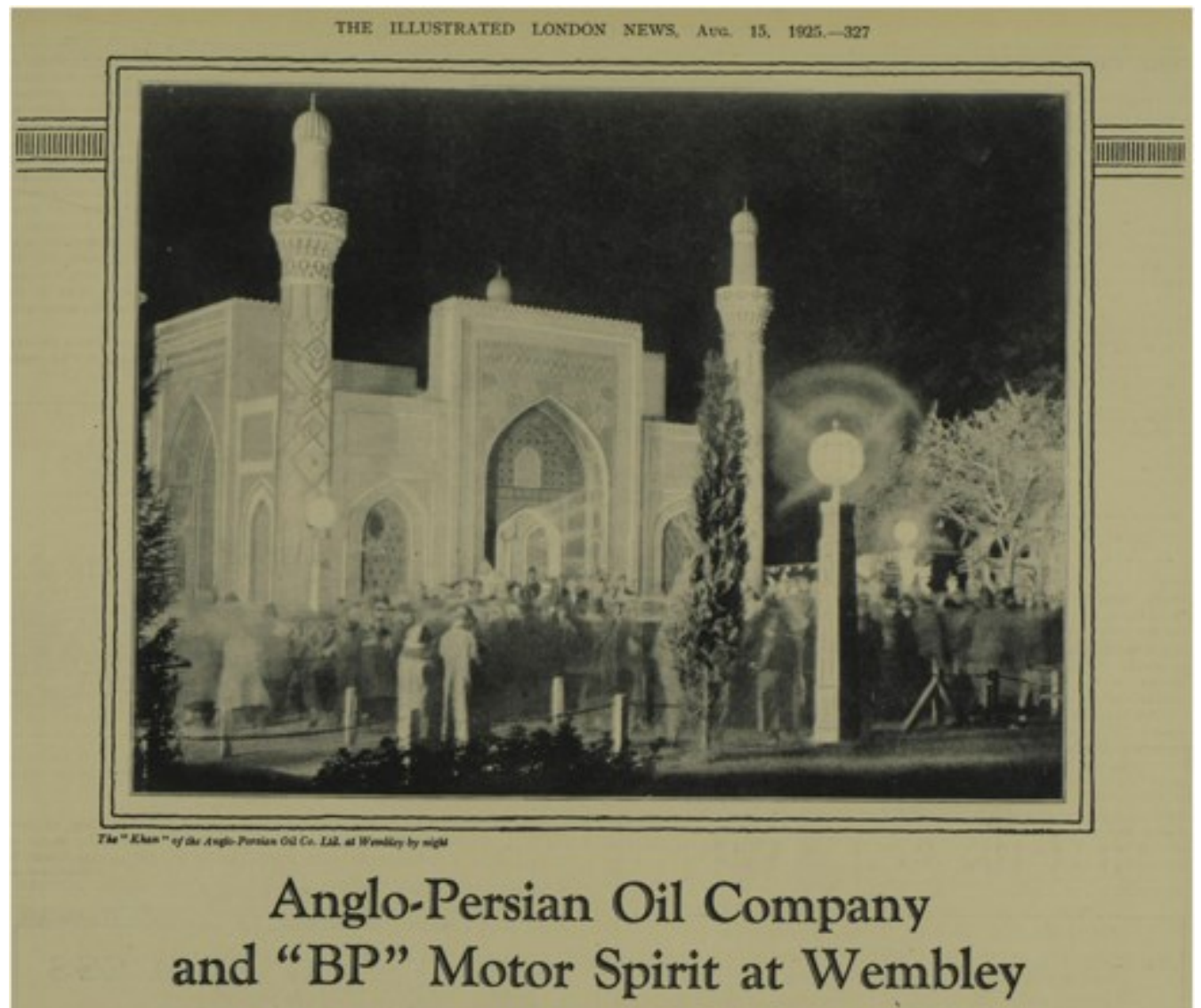

The story of a great national enterprise is told in attractive tableaux in the exhibit of the Anglo-Persian Oil Co. Ltd. at Wembley.

The building itself, which is situated at the east end of the lake, represents a Persian "Khan " or caravanserai such as is found along the caravan routes in Persia where travellers rest from the journey.

The interior exhibit is designed to convey an impression of the more important points in the sequence of activities of the Company. from the production of crude oil up to the distribution of "BP" Motor Spirit and other products - drilling for oil in the Persian fields, conveying the crude oil in British ships to this country refining at Wlandarcy in South Wales, distributing the finished products by rail tank-cars, can-filling operations and the many other activities necessary before " $\mathrm{BP}$ " reaches the motorist.

A visit to the "BP" exhibit will give you a wider and deeper realisation of the great importance of British Petrol, not only to the British motorist but to the Empire at large.

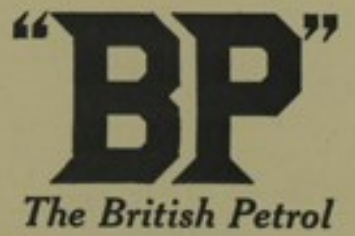

British Petroleum [. Ltd Britannic House.Moorgate.E. 2 Distributing Organization of the ANCLO-PERSIAN OIL CO LTD

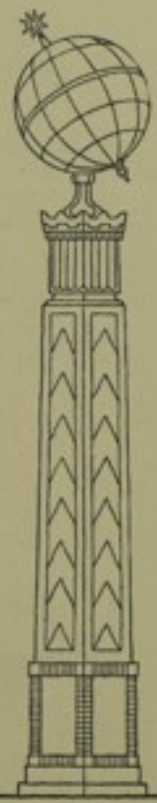

Illustrated London News, 25 August 1925. 
Conclusion: Motor Spirit Marketing and the Construction of British Petroculture

The aim of this chapter has been to reconstruct the processes by which BP marketed its motor spirit products during the period 1919-1925, and to reveal the important function these narratives performed in the making of British petroculture. Very little has been written about British oil company marketing during this period, especially with respect to BP. Though there exists a large body of scholarship on the economic and political aspects of oil during this period, energy historians have generally ignored the ways in which oil companies like BP marketed their products to diverse audiences of British consumers. The literature's silence on these marketing activities has meant that historians have not yet accounted for all of the ways in which oil was imagined in early twentieth century Britain.

The chapter was structured upon several driving questions. How did BP market its motor spirit products to British consumers during the company's formative years, and in what ways did those methods change over time? What images and stories were crafted by $\mathrm{BP}$ to attract the attention of potential consumers, and what were the key messages that the company sought to convey? In 1919, BP had next to no serious marketing materials. During the early 1920s, under the leadership of several executive board members, such as Nichols, Watts, and Braithwaite, BP developed a comprehensive motor spirit marketing campaign designed to attract attention to BP Motor Spirit and encourage its consumption. As the minutes of the board make clear, the company invested heavily in a variety of different marketing activities aimed at creating a coherent brand identity. The Publicity Department's first campaign concentrated on outdoor advertising initiatives that included the placement of posters and roadside signs, and the branding of company-owned 
shipping vessels, rolling stock, and motorized delivery vehicles. Most useful to the motorist were BP's colorful enameled signs displaying the Company's Union Jack logo, which told travelers where they could find garages that sold the best possible motor spirit. The goal of these campaigns was to raise awareness of the $\mathrm{BP}$ brand and its products, showcasing the company's identity in simple yet eye-catching ways.

A central component of BP's marketing of the mid-1920s was the presentation of information and ideas about Persia, the country from which APOC, BP's parent company, acquired supplies of crude oil. Starting in 1924, the company's motor spirit marketing began to include Persian subjects, which presented stories of cultural collision and commercial conquest in foreign lands. In these stories, which culminated in the twelve-part "Persian Series," the modern British motorist was configured as the beneficiary and deserving heir to the buried natural treasures sitting idly beneath foreign Persian landscapes. APOC and BP had successfully launched a commercial conquest of Persia, and a seemingly unlimited supply of motor spirits was the prize.

The pinnacle of BP motor spirit marketing during the 1920s was the company's Persian Khan exhibit, presented at the BEE in 1924 and 1925. The Khan combined the most effective storytelling techniques that the company had learned in its earlier outdoor and print advertising campaigns, and it highlighted how far BP's marketing strategy had come since 1919. The exhibit utilised messaging techniques that mixed education and entertainment, and it was premised on the jarring contradiction between the modern science and technology of oil and the ancient landscapes of Persia. It told the story of commercial conquest on behalf of the British consumer, and the immense energy that was required to deliver BP motor spirit to the nozzle-tip at the local free dealer garage. The 
Persian Khan represented Barrett and Worden's oil spectacle in every sense, designed to leave British audiences in awe about Persian oil and its power to transform daily life. As with all BP motor spirit marketing activities undertaken during these formative years in the company's history, the Khan was designed to capture not only market share, but also the imaginations of British motorists.

In reconstructing these histories of motor spirit marketing, this chapter has asserted that BP's early motor spirit marketing offers valuable insight into the ways in which oil was interpreted and imagined in Britain during the early twentieth century. The Khan was designed to attract the attention of audiences, persuade them to purchase BP products, and thereby increase the company's market share. Much more than a commercial stunt, the Persian Khan represented an archive of creative images and stories about oil, which encouraged and directed its public audiences to think about the resource, and to imagine it in new ways. The Khan worked to influence the imagination of the motoring public, and to shape the development of early British petroculture during the early interwar years. In BP's imagined world of oil, the "Best Possible" motor spirits were those which came from distant, exotic, ancient, and romantic Persia, and which were refined in modern facilities with British science and technology. 


\section{Conclusion}

This dissertation has investigated the cultural history of oil in Britain over a seventy-year period, between 1865 and 1935. Much has been written about the economic, political, diplomatic, geopolitical, and military aspects of oil during these years. Yet, very few scholars have examined the ways that culture has shaped the history of oil in Britain. It is this absence in the literature that this study has sought to fill. Using an Energy Humanities approach, the dissertation probed the themes, stories, and ideas that were constructed to help Britons navigate their changing energy landscapes. The analysis of these sources was organized into four case studies. The first two chapters focused on the work of individuals, the petroleum scientist Sir Thomas Boverton Redwood, and the political cartoonist, Leonard Raven-Hill. The second set of chapters analysed two oil companies: the exploration and extraction firm, the Anglo-Persian Oil Company, and the motor spirit marketing firm, British Petroleum. These individuals and companies each contributed to the making of British petroculture, and they have helped to answer the primary question guiding this dissertation: how was oil imagined in Britain during the late-nineteenth and early-twentieth centuries, and what major themes, stories, and ideas were involved in the shaping of these imaginaries?

In recent years, a new phase of multidisciplinary research has begun to problematize the cultural dimensions of energy, and the influence that oil has exercised upon the ideas and practices of everyday life. Driving this shift in scholarly approaches to energy and oil is the burgeoning field of the Energy Humanities. ${ }^{683}$ As Barrett and

\footnotetext{
${ }^{683}$ Boyer and Szeman, 2014.
} 
Worden have contended, it is the task of the Energy Humanities to disentangle the "many dimensions of oil's cultural existence," and to assess the "creative accounts" and "imaginative interpretations" that have been constructed to make sense of the resource. ${ }^{684}$ These efforts to understand and inscribe oil with new meanings have had the effect, according to Barrett and Worden, of producing in the mind of the consumer an "oil spectacle." ${ }^{685}$ The dissertation applied Barrett and Worden's concepts of "creative accounts," "imaginative interpretations," and "oil spectacle" as tools for analysing the making of petrocultures in Britain during the period 1865-1935.

All of the four case studies have offered an entry point into the cultural history of oil in Britain during the period under review. The task of each chapter was therefore to function as spokes on a wheel, connected to the central hub of oil and reaching outwards into four distinct domains of British petroculture. Chapter One followed the professional career and public life of the analytical chemist and oil expert, Sir Thomas Boverton Redwood, and aimed to foreground his contribution to the development of British oil science. During his long and diverse career, Redwood played the role of oil's explainerin-chief. The depth of Redwood's knowledge on the subject made him an invaluable asset to politicians, oil companies, and professionals, who turned to him as a trusted source of information about oil and its future. As oil products and technologies rapidly entered daily life during the late nineteenth and early twentieth centuries, Redwood operated as the architect of some of the earliest petrocultures in Britain.

The work of British cartoon artist Leonard Raven-Hill is the focus of Chapter Two. Using two of his political cartoons published in Punch magazine, the chapter

\footnotetext{
${ }^{684}$ Barrett and Worden, 2014, xxi, xxiii-xxv.

${ }^{685}$ Barrett and Worden, 2014, xxiii-xxv.
} 
explored the anthropomorphosis of energy into the imaginary characters of King Coal and Prince Petroleo. Employing Barrett and Worden's concept of an "oil spectacle" as a frame of analysis, the chapter aproached Raven-Hill's energy cartoons as efforts to imagine the unimaginable: Britain's early-twentieth century transition from a predominantly coal-fuelled way of life to one increasingly powered by oil. In telling this story of energy in transition, Raven-Hill inscribed King Coal and Prince Petroleo with multiple layers of meaning, employing them as motifs that channelled the cultural dimensions of oil. "A Second String" and "Black Magic; or the New King Coal" were used by Raven-Hill as rhetorical tools for interpreting the transition from coal to oil. They function as signposts in the evolution of British petroculture during the early twentieth century.

The construction of images, stories, and ideas related to the modern science and technology of oil was the centrepiece of the second set of chapters, which turned to analysing the promotional activities of two British oil companies. Chapter Three explored the early history of the Anglo-Persian Oil Company during the period 1909-1925. Using the Llandarcy Refinery as a case study, the chapter traced the ways in which APOC communicated information about oil to targeted British audiences through the hosting of private guided tours and the publication of press advertisements and souvenir booklets. In reconstructing these promotional activities, it was revealed that APOC wished British audiences to envision Llandarcy as a modern, world-class facility of which they could be proud. The Llandarcy Refinery was formulated as a site that provided Britons not only with the oil products that they increasingly needed but, in more symbolic ways, with an engine necessary for driving the transition to the Age of Oil. APOC was not simply an oil 
company that sold goods, it was also an important player, stakeholder, and beneficiary in the making of British petroculture during the early 1920s.

The fourth and final chapter investigated the motor spirit marketing activities of the British Petroleum Company (BP) during the period 1919-1925. The chapter traced the evolution of the company's marketing activities from their modest beginnings in the immediate post-war years to the expensive, multi-dimensional publicity campaigns of the mid-1920s, revealing the ways in which BP used imaginative marketing materials to create an "oil spectacle" in the minds of British consumers. Through these promotional efforts, the company produced a series of creative ideas about oil, which encouraged its public audiences to think about the resource in new ways. The company's Persian Khan exhibit, presented at the British Empire Exhibition in 1924 and 1925, was premised on the jarring conflict between the modern science and technology of oil and the ancient traditions and landscapes of Persia. The Persian Khan represented Barrett and Worden's "oil spectacle" in every sense, designed to leave British audiences in awe over Persian oil and its power to transform daily life. Through its motor spirit marketing activities, BP constructed an imagined world of oil that connected the ancient, exotic, wild and "other" landscapes of Persia, with the modern, technologically advanced landscapes of consumption in Britain.

The four case studies analysed in this dissertation reveal that the historic rise in British oil consumption during the late nineteenth and early twentieth centuries was dependent upon science and technology, but also imagination and creativity. From 1865 to 1935 , the average British consumer used oil in increasing quantities while never really encountering the resource itself. Despite the growing presence of oil in Britain, the 
resource was paradoxically a spectral substance, which was rarely seen or touched directly by the British consumer. However, while oil was generally out of sight, it was certainly not out of mind. The very nature of oil's invisibility demanded that Britons invent novel ways of thinking, talking, and writing about the resource - activities which produced an entirely new archive of imaginaries related to energy and its cultural impact. Even the most basic elements of oil needed to be explained and conceptualized, from the essential questions of what oil was, to more technical enquiries into the science and engineering of oil refining, and the ways in which refined products could be used. It was the task of British scientists, oil companies, journalists, and artists (some of whom were discussed in this dissertation) to give life to oil and the opportunities it afforded the individual consumer. These efforts to understand, interpret, explain, and represent oil constituted a distinct petroculture. The making of this petroculture and its change over time has been the preoccupation of this dissertation.

The project has engaged with four critical engines in the making of British petroculture. It is hoped that they will encourage further research into other neglected individuals, companies, and episodes in the cultural history of oil in Britain. As Chapter One illustrated, Redwood was the doyen of oil in Britain during the early twentieth century, with an international web of professional and personal associations. Very little is known about Redwood, but even less is known about the work of his closest protégés. Energy scholars would benefit from a greater understanding of oil scientists and experts such as Vivian Byam Lewes, James Dodds Henry, and Frederick Talbot, whose work on oil was heavily influenced by Redwoodian thinking. Chapter Two exposed the creative contributions made by Leonard Raven-Hill to British energy discourses. Several of 
Raven-Hill's colleagues also produced energy-themed cartoons during the period covered by this dissertation, particularly his superior at Punch, Bernard Partridge. Partridge's work offers yet another lens through which to view the cultural history of oil in Britain. Chapter Three sought to recover the Llandarcy Refinery from historiographical obscurity, and through this process it was revealed that none of Britain's early oil refineries have been adequately researched. Studies of APOC's other facilities, including the Grangemouth Refinery, in Scotland, and the Sunbury Research Station, near London, would likely bear fruit for any Energy Humanities scholar. Chapter Four focussed on the early motor spirit marketing activities of BP, but there are several other campaigns undertaken by the company that warrant further investigation. In particular, there is scant research on BP motor pageants and ship christening ceremonies. An enriched understanding of these activities would add greater context to the cultural history of oil in Britain.

This dissertation has applied an Energy Humanities approach to the analysis of understudied primary sources and case studies in order to contribute a richer account of the cultural history of oil in Britain. Taken as a whole, the work and actions of Sir Boverton Redwood, Leonard Raven-Hill, the Anglo-Persian Oil Company, and British Petroleum offer a window into the different ways that oil has been imagined as both a physical and cultural object. In mapping the complexities, opportunities, and impasses that accompanied the rise of oil in Britain during the late nineteenth and early twentieth centuries, this dissertation has revealed that the system of things that brought oil from the Persian wellhead to the British consumer was predicated on a vast constellation of ideas. In late-nineteenth and early twentieth-century Britain, oil was an invisible resource 
brought to life through discourse rather than drilling, through conversation rather than chemistry. 


\section{Bibliography}

\section{$\underline{\text { I - Primary Sources }}$}

\section{I.I - Archival Materials}

\section{British Petroleum Archives, Warwick}

\section{Contracts and Agreements}

Agreement between the Anglo-Persian Oil Company and the Great Western Railway. 10 August 1918. ARC 179436-37.

Agreement between the Anglo-Persian Oil Company and Neath Rural District Council.

31 December 1918. ARC 179436-75.

Agreement between the Lords Commissioners of His Majesty's Treasury, The

Commissioners for Executing the Office of Lord High Admiral of the United

Kingdom of Great Britain and Ireland, and the Anglo-Persian Oil Co. Ltd., for the

Purchase of Shares in the Anglo-Persian Oil Co. Ltd. by His Majesty's

Government. 20 May 1914. ARC 106214-106215

Anglo-Persian Oil Company. The Commissioners for Executing the Office of the Lord High Admiral of the United Kingdom of Great Britain and Ireland - Contract for the Supplying of Oil Fuel. 20 May 1914. ARC 106215.

Anglo-Persian Oil Company. Report and Abstract of the Receipts and Payments of the Company. 12 July 1909. ARC 128739.

Programme of the Opening Ceremony at the New Refinery of the National Oil Refineries Ltd. at Llandarcy by the Right Hon Stanley Baldwin President of the Board of Trade. 29 June 1922. ARC 094102.

\section{$\underline{\text { Internal Company Files }}$}

Anglo-Persian Oil Company. Llandarcy Refinery Inauguration Stamp. 1922. ARC 32103.

Anglo-Persian Oil Company. Plan of Swansea Harbour, Queen's Docks, and Llandarcy Refinery - Industrial Development by APOC. 1915-1919. ARC 195848.

Anglo-Persian Oil Company. Report of the Directors and Balance Sheet. 31 March 1917. ARC 29852/3. 
Anglo-Persian Oil Company. Report of the Directors and Balance Sheet. 31 March 1915. ARC 29854/3.

British Petroleum. Comparative Statement of Publicity Policy. 12-13 May 1931. ARC 78/38/19.

British Petroleum. General Company Letter Book, No. 9. 1921. ARC 54506.

British Petroleum. Minutes of Board Meetings. 1919-1926. ARC 104206.

Correspondence of Charles Greenway. 9 May 1922. ARC 94098- ARC 94098.

Correspondence of W.T. Watts. 1 September 1919-December 1922. ARC 70007.

National Oil Refineries. General Ledger. 1922-1932. ARC 93632-195847.

$\underline{\text { In-House Publications }}$

Anglo-Iranian Oil Company. Fifty Years of Oil. London: The Company, 1952.

Anglo-Iranian Oil Company. The Anglo-Iranian Oil Company and Iran. London: The Company, 1951.

Anglo-Iranian Oil Company. Llandarcy Refinery. London: The Company, 1948.

Anglo-Iranian Oil Company. The Record of the Anglo-Iranian Oil Co., Ltd., Vol. 1, 1901-1918. London: The Company, 1938.

Anglo-Persian Oil Company. The Persian Oil Industry: An Account of Its Origin and Development. London: The Company, 1927.

Anglo-Persian Oil Company. In the Land of the Shah: Being a Series of Announcements Issued by the British Petroleum Co. Ltd. 1 January 1925 - 31 December 1925. ARC 176238.

Anglo-Persian Oil Company. Llandarcy. London: The Company, 1925. ARC 67896.

Anglo-Persian Oil Company. Llandarcy: England's New Industry. London: The Company, 1922.

Barnes, V. A History of Llandarcy, 1921-1971. London: British Petroleum, 1972.

BP Shipping. Riding the Waves: BP Shipping, 1915-1925. London: The Company, 2015.

British Petroleum. Environmental Issues. 1996. 
British Petroleum. Good Neighbours: 75 Years of Refining, 1921 to 1996. 1996.

British Petroleum. BP Oil Llandarcy Refinery Limited. 1994.

British Petroleum. Llandarcy, Products, Customers and Product Uses. 1994.

British Petroleum. BP Oil: Llandarcy Refinery. 1993.

British Petroleum. Britannic House: A Palace Upon a Cliff. London: The Company, 1991.

British Petroleum. Llandarcy Refinery. London: The Company, 1953.

British Petroleum. Our Industry: An Introduction to the Petroleum Industry for the Use of Members of the Staff. London: The Company, 1947.

British Petroleum. Llandarcy: A Survey. London: The Company, 1937.

British Petroleum. Llandarcy Refinery, South Wales. London: The Company, 1935.

Griffiths, V. Llandarcy to Coed Darcy: A Look Back and a Glimpse of the Future. DVD, 56m. August 2015. ARC 252004.

Institution of Mining Engineers. Llandarcy. London: The Institution, 1925. ARC 67896.

James, H. B.P. Oil-Llandarcy, 1921-2000. DVD. 2008. ARC 221864.

Lockhart, L. The Record of the Anglo-Iranian Oil Company, Ltd. London: Anglo-Iranian Oil Company, 1938.

Lockhart, L., and R. Greaves. The Record of the British Petroleum Limited (1918-1946) Relations with the Persian (Iranian) Government. London: British Petroleum Company, 1968.

British Petroleum. History of Llandarcy Refinery. DVD. No date. ARC 221865.

\section{Marketing Materials}

Anglo-Persian Oil Company. Invitation Card from the Chairman and Directors of the Anglo-Persian Oil Company. 24 July 1924. ARC 210927.

Anglo-Persian Oil Company. Seating Plan for the Anglo-Persian Oil Company Limited, at the Lucullus Restaurant, Wembley. 24 July 1924. ARC 210928. 
British Petroleum. The Motorist's Rhyme Book. London: The Company, 1929.

British Petroleum. File of Press Advertisements. 1924-1928. ARC 145002.

British Petroleum. Wembley. London: The Company, 1925. ARC 18791.

British Petroleum. Postcard: Wembley. 1924. ARC 206530.

British Petroleum. Press Cuttings Relating mostly to the Opening Ceremony of Llandarcy. 1922. ARC 117376.

$\underline{\text { Photographic Materials }}$

Anglo-Persian Oil Company. A Selection of Photographs Depicting the Operations of the Anglo-Persian Oil Company in Persia and South Wales. 1920-1926. ARC36529.

Anglo-Persian Oil Company. Underwood-Keystone Stereographs: Stereoscopic Views of the Oil Refinery in South Wales and Distribution Centre in London. 1924. ARC 29341.

Anglo-Persian Oil Company. Collection of Back and White Negatives. 1924. ARC 209175.

British Petroleum. Photograph of refined oil product exhibition, Burmah Oil Company, Wembley. 1924. ARC 134948-01.

British Petroleum. Testing Laboratory. 1924. ARC 209168.

British Petroleum. Photograph: the Llandarcy Refinery. 1922. ARC 209171.

British Petroleum. Photograph: the Llandarcy Refinery. 1922. ARC 209170.

\section{National Library of Wales, Aberystwyth}

Back to Coal Movement. Memorandum re Appeal to the Rt. Hon. Stanley Baldwin, P.C., M.P., Lord President of the Council, for Meeting on Thursday, $21^{\text {st }}$ April, 1932, at 11.0 a.m. at Privy Council Office, Whitehall, London. 1932. Monmouthshire and South Wales Coal Owners Association Records. Box 1, A4/4/26.

Back to Coal Movement. Minutes of Proceedings of an Address given by Captain Bernard Acworth, D.S.O., R.N. on 'The Navy's Fuel. 1931-1932. Monmouthshire and South Wales Coal Owners Association Records, Box 1, A4/3/5. 
Back to Coal Movement. The Navy's Fuel. A Petition to the Lords Commissioners of the Admiralty. 26 June 1931. Monmouthshire and South Wales Coal Owners

Association Records, Box 1, A4/3/1.

Coal Utilisation Council. Aims and Policies. London: The Council, 1933.

Coal Utilisation Council. Report on the Coal Industry and the Fuel Distribution Trades of Great Britain. 1933. Monmouthshire and South Wales Coal Owners' Association Records, Box 2, P6/5/1-45.

Fuel Research Board. Fuel for Motor Transport: Third Memorandum. London:

Department of Industrial and Scientific Research, 1925.

Miners' Federation of Great Britain. Annual Volume of Proceedings for the Year 1933. London: Co-operative Printing Society, 1934.

\section{Richard Burton Archives, Swansea}

National Oil Refineries. Map of Abadan and South West Persia. 1924-1935. MPKK $1 / 17 / 1$.

National Oil Refineries. Estate Rentals: House Property at Llandarcy, Jersey Marine, and Cefn Park. c. 1922. LAC/66/C/1.

National Oil Refineries. Journal No. 9. 1921-1922. LAC/66/A/12.

National Oil Refineries. Transfer Binder 1. 1921-1922. LAC/66.

National Oil Refineries. Llandarcy Oil Refinery, Journal. 1919-1921. LAC/66/A1/525529.

\section{West Glamorgan Archives, Swansea}

Braithwaite, W. Distribution of Motor Spirit in England. London: Anglo-Persian Oil Company, May 1927. H18/21.

British Petroleum Company. British Empire Exhibition, Wembley: The Lake and Palaces of Industry, Engineering, India, Canada, and Australia.1924. PIC 4/11/80-81.

British Petroleum. Oil For the $20^{\text {th }}$ Century. DVD and VHS. No date. D/D SIH 1/3.

Griffiths, V., Davies, R., and H. James. BP Llandarcy: Happy Days. No date. DVD, 26 minutes. D/D SIH 1/4. 
National Oil Refineries. Llandarcy Refinery and Village. Photographic Collection. c. 1922. D/DZ 201/23-25.

National Oil Refineries. Agreement with the British Steel Corporation to Sell Land at Llandarcy. 1919. D/D BF/E 785.

National Oil Refineries. Llandarcy Village: Elevations. c. 1918. WGCC/EH 16/6.

National Oil Refineries. Folder containing photographs of industrial sites including Llandarcy. Undated. D/D SIG 4/42.

Pinschewer, J. King Coal. 1948. 35 mm. 3:00 minutes. National Coal Board Film Unit.

\section{I.II - Government Materials}

\section{Great Britain}

Department for Business, Energy \& Industrial Strategy. Crude Oil and Petroleum Products: Imports by Product 1920-2015. London: Her Majesty's Stationary Office, 2016.

Department for Business, Energy \& Industrial Strategy. Crude Oil and Petroleum: Production, Imports and Exports 1890 to 2015. London: Her Majesty's Stationary Office, 2016.

Department of Energy and Climate Change. Historical Coal Data: Coal Production, Availability and Consumption 1853-2014. London: Her Majesty's Stationary Office, 2015.

Departmental Committee on Petroleum Spirit. Final Report. Cd. 6565. 1913.

Departmental Committee on Petroleum Spirit. Cd. 5175. 1910.

Diplomatic and Consular Reports. Persia. Report for the Year Ending March 20, 1911 on the Trade and Commerce of the Province of Arabistan. Cd. 6005. 1912-1913.

House of Commons Debate. Navy Estimates, 1912-1913. 18 March 1912, cc. 1549-1618.

House of Commons Debate. Coal Mines (Minimum Wage) Bill. 19 March 1912. vol.35, cc1723-93.

House of Commons Debate. Coal Mines (Minimum Wage) Bill. 29 March 1912. vol.36, c758.

House of Commons Debate. Persia. 21 July 1914. cc. 232-236. 
House of Commons Debate. Anglo-Persian Oil Company. 14 March 1922. cc. 21292142.

House of Commons Debate. Anglo-Persian Oil Company. 21 March 1922, cc. 257-258.

House of Commons Debate. Fuel Oil. 26 June 1922. c. 1655.

House of Commons Debate. Dominion and Colonial Affairs. 29 July 1926. cc. 23292463.

House of Commons Debate. Economic Situation. 26 July 1933. cc. 2621-2718.

House of Lords Debate. Coal Mines (Minimum Wage) Bill. 28 March 1912. vol.11, cc729-81.

Report of the Royal Commission on the Coal Industry. Cmd. 2600. 1925.

Report of the Royal Commission on the Distribution of the Industrial Population. Cmd. 6153. 1939-1940.

Report of the Royal Commission on Population. Cmd. 7695. 1948-1949.

Royal Commission on Environmental Pollution. Eighth Report: Oil Pollution of the Sea. Cmd. 8358. 1981.

Royal Commission on the Coal Industry. Cd. 1724. 1903.

Royal Commission on the Supply of Food and Raw Material in Time of War. Cd. 2643. 1905.

United Kingdom Parliamentary Papers. Army. Military Aeroplane Competition, 1912. Report of the Judges Committee. Cd. 6286. 1912.

United Kingdom Parliamentary Papers. Army. Memorandum on Naval and Military Aviation. Cd. 6067. 1912.

United Kingdom Parliamentary Papers. Army. Military Aeroplane Competition. Report of Judges Committee. Cd. 6286. 1912.

United Kingdom Parliamentary Papers. Royal Commission on Motor Cars, Vol. 1, Report. Cd. 3080. 1906.

\section{United States}


Clarke, F. The Data of Geochemistry. 59 ${ }^{\text {th }}$ Congress. 1908.

Day, D. Mineral Resources of the United States. 53 ${ }^{\text {rd }}$ Congress. 1894.

Fire and Building Regulations in Foreign Countries. Consular Reports, Vol. VII. Washington: Government Printing Office, 1892.

\section{I.III - Journals and Magazines (cited)}

\begin{tabular}{|c|c|}
\hline A Thousand and One Uses for Gas & Ocean and National Magazine \\
\hline Art Journal & Oil Age \\
\hline Automobile Club Journal & Oil and Colourman's Journal \\
\hline Automotor Journal & Oil and Gas Journal \\
\hline British Medical Journal & Oil Engineering and Finance \\
\hline Bulletin of the Torrey Botanical Club & Oil News \\
\hline Bystander & Oil Trade Review \\
\hline Chemistry and Industry & Oildom \\
\hline Colliery Guardian & Pall Mall Gazette \\
\hline Commercial Motor & Petroleum Age \\
\hline Cosmopolitan & Petroleum Review \\
\hline Financial Times & Petroleum Times \\
\hline Flambeau & Pick-Me-Up \\
\hline Flight & Popular Mechanics Magazine \\
\hline Garage and Motor Agent & Punch \\
\hline Geographical Journal & Quarterly Journal of the Geological \\
\hline Graphic & Society \\
\hline Grocer & Radical Review \\
\hline Gwyddonydd & RUSI Journal \\
\hline Imperial Oil Review & Saturday Review of Politics, Literature, \\
\hline John Bull & Science and Art \\
\hline Journal of the Franklin Institute & Science \\
\hline Journal of the Institute of Metals & Scientific American \\
\hline Journal of the Institute of Petroleum & Sketch \\
\hline Technology & Sphere \\
\hline Journal of the Royal Society of Arts & Tatler \\
\hline Lloyd's List & Thalos Review \\
\hline London Gazette & The Autocar \\
\hline Mechanical Engineer & The Engineer \\
\hline Modern Transport & The Motor \\
\hline Motor Car Journal & The Standard \\
\hline Motor Cycle & The Unicorn \\
\hline Motorist's Year Book & Travel \\
\hline Naft-i-Iran (Naft: APOC Magazine/Naft). & United Empire \\
\hline National Petroleum News & Vanity Fair \\
\hline
\end{tabular}


Nature

Naval Review

New Statesman

\section{I.IV - Newspapers (cited)}

Aberdeen Press and Journal (Aberdeen)
Barnet Press (Barnet)
Barry Dock News (Barry)
Bath Chronicle (Bath)
Belfast Telegraph (Belfast)
Belper News (Chesterfield)
Birmingham Daily Gazette (Birmingham)
Birmingham Daily Post (Birmingham)
Buckingham Advertiser and Free Press
(Buckingham)
Cambria Daily Leader (Swansea)
Cardiff Weekly Mail (Cardiff)
Cornishman (Penzance)
Daily Express (London)
Daily Graphic (London)
Daily Herald (London)
Daily News (London)
Daily Sketch (Manchester)

Dartmouth \& South Hams Chronicle (Dartmouth)

Dundee Courier (Dundee)

Dundee Evening Telegraph (Dundee)

El Paso Herald (El Paso, TX)

Exeter and Plymouth Gazette (Exeter)

Evening Star (Washington, D.C.)

Glamorgan Gazette (Bridgend)

Globe (Toronto)

Citizen (Cheltenham)

Gloucestershire Chronicle (Gloucester)

Hartlepool Northern Daily Mail

(Hartlepool)

Hendon \& Finchley Times (London)

Hull Daily Mail (Hull)

Idler (London)

Illustrated London News (London)

Illustrated Sporting and Dramatic News

(London)

Lancashire Evening Post (Preston)

Leeds Mercury (Leeds)
Wheel World

$Y$ Gwyddonydd
Llangollen Advertiser (Llangollen)

London Daily News (London)

London Evening Standard (London)

Manchester Courier (Manchester)

Manchester Guardian (Manchester)

Morning Journal and Courier (New

Haven, CT)

Morning Post (London)

New York Tribune (New York, NY)

Northern Whig (Belfast)

Observer (Manchester)

Omaha Daily Bee (Omaha, NB)

Pittsburgh Dispatch (Pittsburgh)

Portsmouth Evening News (Portsmouth)

Public Ledger and Daily Advertiser

(London)

Scotsman (Edinburgh)

Sheffield Daily Telegraph (Sheffield)

Sheffield Independent (Sheffield)

South Wales Daily Post (Swansea)

South Wales Echo (Cardiff)

South Wales Evening Express (Cardiff)

South Wales Evening Post (Swansea)

South Wales Journal of Commerce

(Cardiff)

South Wales News (Cardiff)

Sussex Agricultural Express (Lewes)

Sunday Times (London)

Sunderland Daily Echo (Sunderland)

The Times (London)

The Times of India (Mumbai)

Weekly Mail (Cardiff)

Wells Journal (Wells)

Western Daily Press (Bristol)

Western Mail (Cardiff)

Western Morning News (Plymouth)

Westminster Gazette (London)

Wigan Observer (Manchester)

Windsor and Eaton Express (Windsor) 
Lincoln County Leader (Toledo, OR)

Lincolnshire Echo (Lincolnshire)

Liverpool Journal of Commerce

(Liverpool)

Liverpool Mercury (Liverpool)
Yorkshire Observer (Yorkshire)

Yorkshire Post and Leeds Intelligencer

(Yorkshire)

Yorkshire Evening Post (Yorkshire)

\section{I.V - Published Primary Sources}

Abercrombie, P. “The Preservation of Rural England.” Town Planning Review 12, no. 1 (May 1926): 12.

A.C.H. "Book Review: C. Brunner, The Problem of Oil." Journal of the Royal Institute of International Affairs 9, no. 3 (1930): 400-401.

Acworth, B. "Coal in Relation to Transport and Power," Great Western Railway (London) Lecture and Debating Society, no. 276 (16 November 1933): 1-13.

Acworth, B. Back to the Coal Standard: The Future of Transport and Power. London: Eyre and Spottiswoode, 1932.

Acworth, W. The Railways and the Traders. London: John Murray, 1906.

Agnew, H. Outdoor Advertising. New York: McGraw Hill, 1938.

American Petroleum Institute. National Code for Practices for Marketing Refined Petroleum Products. New York: The Institute, 1929.

American-Ventura Oil Company. The Age of Oil. Los Angeles: The Company, 1916.

Amery, L. "Impressions of My Visit to the Anglo-Persian Oil Company in Persia." Naft 1, no. 5 (July 1925): 20.

Anderson, G. Romance of Royalty. Fort Worth: Tanner-Williams, 1928.

Anderson, W. "Petroleum: Its Sources and Uses." Journal of the Royal Agricultural Society of England 3 (1892): 376.

Anderson, W. "The Origin of Petroleum.” Journal of the Royal Society of Arts (20 September 1889).

Andrew, G. Fuel. London: Ernest Benn, 1924.

Andros, S. Fuel Oil in Industry. Chicago: Shaw, 1920.

Antrobus, W. Oil. London: John Heywood, 1913. 
Appleby, H. Great Western Ports. Cardiff: The Author, 1931.

Arnold, R. "Two Decades of Petroleum Geology.” AAPG Bulletin 7, no. 6 (1923): 603624.

Arnot, R. The Politics of Oil: An Example of Imperialist Monopoly. London: Labour Publishing, 1924.

Bacon, R., and W. Hamor. The American Petroleum Industry. New York: McGraw Hill, 1916.

Baker, H. The Age of Oil: A History of Petroleum Industry and the Outlook for the Future. New York: The Company, 1917.

Baker, M., and J. McCormick. Geographic Dictionary of Alaska. Washington: Government Printing Office, 1906.

Barton, B. The Man Nobody Knows. Indianapolis: Gosset \& Dunlap, 1925.

Baxter, F. Petroleum: A Class Room Talk. Rochester, NY: Vacuum Oil, 1905.

Beeby-Thompson, A. Oil Pioneer. London: Sidgwick and Jackson, 1961.

Beeby-Thompson, A. Report on the Daga Shabell Oilfield. Cairo: Government Press, 1918.

Beeby-Thompson, A. Petroleum Mining and Oil-Field Development. London: Crosby Lockwood, 1910.

Beeby-Thompson, A. Oil Fields of Russia and the Russian Petroleum Industry. London: Crosby Lockwood, 1908.

Beeby-Thompson, A. The Oil Fields of Russia. London: Crosby Lockwood, 1904.

Bell, E. History of Petroleum. Titusville, PA: The Bugle, 1900.

Bell, R. "The Petroleum Field of Ontario." Transactions of the Royal Society of Canada 5 (1887): 101.

Bonn, C. The Oil Tanker. London: Association of Engineering and Shipbuilding Draughtsmen, 1922.

Booth, W. Liquid Fuel and Its Combustion. London: Archibald Constable, 1903. 
Bowden-Smith, E. Oil Firing for Kitchen Ranges and Steam Boilers. London: Archibald Constable, 1920.

Boyd, R. Petroleum: Its Development and Use. London: Whittaker, 1895.

Boyd, T. Gasoline: What Everyone Should Know About It. New York: Frederick A. Stokes, 1925.

Brading, C. "The Floods of Persia." Naft 1, no. 1 (July 1924): 10-15.

Bradshaw, P. Art in Advertising: A Study of British and American Pictorial Publicity. London: The Press Art School, 1925.

Braham, N. "Sic Transit Gloria Mundi." Naft 3, no. 5 (September 1927): 25.

Brame, J. "Power Fuel for the Services.” RUSI Journal 76, no. 501 (1931): 64-81.

British Empire Exhibition. Official Map. London: Dobson, Molle \& Co, 1924.

British Empire Exhibition. A Souvenir of the British Empire Exhibition, Wembley. London: Fleetway, 1924.

British Empire Exhibition. Official Guide to the British Empire Exhibition. London: Fleetway, 1924.

British Empire Exhibition. Opening Ceremony by H.M. the King accompanied by H.M. the Queen, 1925.

British Science Guild. Natural Sources of Energy. London: the Guild, 1910.

Bruere, R. "Our Chained Prometheus: The Coal Problem and its Solution." Harper's Monthly Magazine 147, no. 881 (October 1923): 609.

Brunner, C. Large-Scale Organisation and Change: A Study in Oil Marketing. London: Westerham, 1959.

Brunner, C. Britain's Roads: Paralysis or Progress? London: British Roads Federation, 1954.

Brunner, C. The Place of a Modern Road System in the National Economy. London: Town Planning Institute, 1952.

Brunner, C. Traffic Problems: With Particular Relations to South Wales. London: Institute of Highway Engineers, 1949.

Brunner, C. The Problem of Oil. London: Ernest Benn, 1930. 
Brunner, C. Road Versus Rail: The Case for Motor Transport. London: Ernest Benn, 1929.

Brunner, C. The Problem of Motor Transport: An Economic Analysis. London: Ernest Benn, 1928.

Burrell, G. Gasoline and How to Use It. Boston: Oil Statistical Society, 1916.

Cadman, J. “The British Fuel Problem - Oil.” Naft 8, no. 1 (1932): 11-14.

Cadman, J. “The Oil Era and the British Empire.” Naft 3, no. 2 (March 1927): 11.

Campbell, A. Petroleum Refining. London: Charles Griffin, 1918.

Canjels, R. "From Oil to Celluloid: A History of Shell Films." In J. Jonker, et al. (Eds.), A History of Royal Dutch Shell, Vol. 4. London: British Film Institute, 2010.

Carmichael, W. "Liquid Fuel.” Scientific American 64 (1891): 323.

Chesterton, G. "Our Notebook.” Illustrated London News, 24 May 1924, 930.

Churchill, W. The World Crisis, Vol. 1. New York: Scribner, 1923.

Clarke, T. "British Empire Exhibition: Second Phase." $19^{\text {th }}$ Century (February 1925): $175-182$.

Clowes, F. The Detection and Measurement of Inflammable Gas and Vapour in the Air. London: Crosby Lockwood, 1896.

Cooke, S., and E. Davenport. The Oil Trusts and Anglo-American Relations. New York: Macmillan, 1924.

Coste, E. The Volcanic Origin of Natural Gas and Petroleum. Ottawa: Canadian Mining Institute, 1903.

Cronshaw, H. Oil Shales. London: John Murray, 1921.

Crum, A. The Romance of American Petroleum and Gas. New York: Marcy, 1911.

Cunningham-Craig, E. Oil Finding: An Introduction to the Geological Study of Petroleum. London: E. Arnold, 1920.

Danby, A. Natural Rock Asphalts and Bitumens. London: Archibald Constable, 1913. 
Davenport, E., and S. Cooke. The Oil Trusts and Anglo-American Relations. London: Macmillan, 1923.

Davis, A. “Romance of California Oil.” Overland 61 (1913): 124-134.

Day, D. A Handbook of the Petroleum Industry. London: Chapman, 1922.

Delaisi, F. Le Pétrole [Oil: Its Influence on Politics]. London: The Labour Publishing Company, 1920 [1922].

Dowling, D., et al. Investigations in the Gas and Oil Fields of Alberta, Saskatchewan, and Manitoba. Ottawa: Department of Mines, 1919.

Doyle, P. Petroleum: Its History, Origin and Use. Brisbane: Keogh, 1880.

Dubreil Oil Works. History of Petroleum, Ancient and Modern. Baltimore: The Company, 1868.

Dunstan, A. (Ed.). The Petroleum Industry. London: Institute of Petroleum Technologists, 1922.

Eaton, S. Petroleum: A History of the Oil Region of Venango County, Pennsylvania. Philadelphia: Skelly, 1866.

Ell, F. "Artistic Advertising." School Arts (May 1923): 521-523.

Ellis, C., and J. Meigs. Gasoline and Other Motor Fuels. New York: D. Van Nostrand, 1921.

Engler, C., and H. Hofer. Das Erdol. Leipzig: Hirzel, 1909.

Erni, H. Coal Oil and Petroleum: Their Origin, History, Geology and Chemistry. Philadelphia: Baird, 1865.

Fansler, P. House Heating with Oil Fuel. New York: Heating and Ventilating Magazine, 1925.

Findlay, A. A Hundred Years of Chemistry. London: Gerald Duckworth, 1937.

Findlay, A., and W. Mills. British Chemists. London: The Chemical Society, 1947.

Fischer, L. Oil Imperialism: The International Struggle for Petroleum. London: Allen \& Unwin, 1926.

Fisher, J. Memories. London: Hodder and Stoughton, 1919. 
Francis, E. "Structural Standardization of Outdoor Advertising." Advertising Outdoors 19 (July 1928): 7-10.

Freeman, L. “Age of Oil.” Review of Reviews 48 (1913): 454-464.

Gairns, J. “Petrol Tractors.” Cassier's 32 (1907): 84-92.

Gander, J. Oil Fuel Burning at Sea and On Land. Glasgow: James Munro, 1923.

Gardner, F. "Introduction: Motor Spirits, Solvents, Diesel Fuels, Etc.” In A. Dunstan (Ed.). The Science of Petroleum, Vol. IV. London: Oxford University Press, 1938.

Garfias, V. Petroleum Resources of the World. New York: John Wiley, 1923.

Goldingham, A. The Design and Construction of Oil Engines. London: Spon, 1900.

Gordon, K. “Coal Products and National Defence.” RUSI Journal 77 (1932): 547-558.

Graham, L. The Romance of Texas Oil. Forth Worth: Tariff, 1935.

Graves, C. Mr. Punch's History of Modern England, Vol. 4, 1892-1914. London: Cassell, 1922.

Greene, J., et al. A Treatise on British Mineral Oil. London: Charles Griffin, 1919.

Greenwood. E. Prometheus, U.S.A. New York: Harper, 1929.

Griffiths, J. Between Two Wars: Coal. London: Labour Party, 1942.

Grover, F. A Practical Treatise on the Modern Gas and Oil Engines. Manchester: Engineering Technical Publishers, 1897.

Guttentag, W. Petrol and Petroleum Spirits. London: Edward Arnold, 1918.

Hannington, W. The Problem of the Distressed Areas. London: Victor Gollancz, 1937.

Harp, A. Days with Industrials. London: Trubner, 1889.

Harris, G. Oil and Gas in Louisiana. Washington: US Geological Survey, 1910.

"H.T.B." "Distribution and Economics of Petroleum." Geographical Journal 29, no. 5 (May 1907): 565-566.

Henry, J. History and Romance of the Petroleum Industry. London: Bradbury Agnew, 1914. 
Henry, J. Oil Fuel and the Empire. London: Bradbury Agnew, 1908.

Henry, J. Thirty-Five Years of Oil Transport: The Evolution of the Tank Steamer. London: Bradbury Agnew, 1907.

Henry, J. Baku: An Eventful History. London: Constable, 1905.

Henry, J. H. History and Romance of the Oil Industry. Philadelphia: James B. Rogers, 1873.

Herbert, A. “Advertising as an Art." Arts and Decoration (November 1921): 62.

Hicks, J. The Laboratory Book of Mineral Testing. London: Charles Griffin, 1906.

Henry, J.H. The Early and Latter History of Petroleum. Philadelphia: J.B. Rodgers, 1873.

Herdsman, W. A New Theory of the Earth's Structure, Geologically Considered. Glasgow: N.P., 1917.

Hodgetts, E. Liquid Fuel for Mechanical and Industrial Purposes. London: Spon, 1890.

Hume, G. Oil and Gas in Western Canada. Ottawa: Geological Survey of Canada, 1928.

Illingworth, S. The Co-Operation of Science and Industry. London: Charles Griffin, 1914.

Imperial Institute. Petroleum. London: John Murray, 1921.

Imperial War Museum. Official History of the Ministry of Munitions, Vol. 1, Industrial Mobilizations, 1914-1915. Luton: Andrews, 2012.

Independent Oil Men's Association. Petroleum Annual: Handbook of the Petroleum Industry. Chicago: The Association, 1921.

International Labour Office. The World Coal-Mining Industry. Geneva: The Office, 1938.

Jaffe, B. Crucibles: The Lives and Achievements of the Great Chemists. New York: Tudor, 1930.

James, F. Guides to the Royal Institution of Great Britain: History. London: The Institution, 2000.

Jansen, P. Petroleum Products and Its Transport. South Shields: T.L. Ainsley, 1925.

Jevons, S. The Coal Question: An Enquiry Concerning the Progress of the Nation, and the Probable Exhaustion of Our Coal Mines. London: MacMillan, 1865. 
Johnson, C. "The Horseless Carriage." Journal of the Society of Arts 54 (17 November 1905): 359-376.

Jones, C. Service Station Management, Its Principals and Practice. New York: D. Van Nostrand, 1922.

Jones, C. “Oil on the Caribbean and Elsewhere." North American Review 202, no. 719 (October 1915): 536-543.

Jones, J. "The Present Position of the British Coal Trade." Journal of the Royal Statistical Society 93, no. 1 (1930): 1-63.

Kauffer, E. (Ed.). The Art of the Poster: Its Origin, Evolution and Purpose. London: Cecil Palmer, 1924.

Knaufft, E. “Art in Advertising.” Review of Reviews (June 1922): 625-634.

Knight, C. “The Right Spirit in Advertising.” Commercial Art (December 1929).

Lambert, R. Art in England. Harmondsworth: Penguin, 1938.

La Salle Extension University. Service Station Salesmanship. Chicago: The School, 1930).

Lawrence, G. (Ed.). Official Guide to the British Empire Exhibition. London: Fleetway, 1924.

Leacock, S. "In Praise of Petroleum.” Naft 7, no. 5 (September 1931): 21-22.

Leigh-Bennett, E. An Adventure in Oil. London: Shell-Mex \& BP, 1931.

Lewes, V. Oil Fuel. London: Collins, 1913.

Lewes, V. "Liquid Fuel.” Journal of the Royal Society of Arts 61 (23 May 1913): 666673.

Lewes, V. Liquid and Gaseous Fuels and the Part they Play in Modern Power Production. London: A. Constable, 1907.

Lewes, V. Acetylene: A Handbook for the Student and Manufacturer. Westminster: A. Constable, 1900.

Lewes, V. Laboratory Note Book for Chemical Students. Westminster: A. Constable, 1900. 
Lewes, V. Air and Water. London: Methuen, 1892.

Lewes, V. "Cantor Lectures on Acetylene.” Journal of the Royal Society of Arts 47 (1898): 141-151.

Lewes, V. “Cantor Lectures on Gaseous Illuminants.” Journal of the Royal Society of Arts 39 (1890): 141-151.

Lewes, V. Service Chemistry: Being a Short Manual of Chemistry and its Applications in the Naval and Military Services. London: Whittingham, 1889.

Lewes, V. Inorganic Chemistry, with a Short Account of its More Important Applications. London: Whittingham, 1889.

Lidgett, A. Petroleum. London: Isaac Pitman, 1919.

Lidgett, A. "Gasoline's Part in the Great War." Scientific American 85, no. 2198 (1918): 102-103.

Lilley, E. The Oil Industry. New York: D. Van Nostrand, 1925.

Lockhart, L. The Record of the Anglo-Iranian Oil Company, Ltd. London: Anglo-Iranian Oil Company, 1938.

Lockhart, L. ““BP’ by O.K.” Naft 2, no. 6 (November 1926): 36-37.

Lockhart, L. “The Oil of Iraq: An Historical Outline.” Naft 1, no. 6 (October 1925): 14.

Lord Gainford. "The Coal Problem.” Contemporary Review 119 (January/June 1921): 721-737.

Lubin, I., and H. Everett. The British Coal Dilemma. London: Allen \& Unwin, 1927.

Lucas, E. Zigzags in France. London: Methuen, 1925.

Lucas, E. Highways and Byways in Sussex. London: Macmillan, 1904.

Ludwell, D. We Fight for Oil. London: Alfred Knopf, 1928.

Macnab, W., and W. Ramsay (Eds.). Seventh International Congress of Applied Chemistry. London: Partridge \& Cooper, 1910.

Marcosson, I. The Black Golconda, The Romance of Petroleum. New York: Harper, 1924.

Marshall, L. The Sinking of the Titanic. Philadelphia: John Winston, 1912. 
Marvin, C. The Region of Eternal Fire. London: Allen, 1891.

Marvin, C. The Coming Oil Age: Past, Present \& Future. London: R. Anderson, 1889.

Marvin, C. The Petroleum Question: Our Unappreciated Petroleum Empire. London: R. Anderson, 1889.

Marvin, C. The Petroleum Question: England as a Petroleum Power. London: R. Anderson, 1887.

Marvin, C. The Moloch of Paraffin. London: R. Anderson, 1887.

Marvin, C. The Petroleum Question: The Coming Deluge of Russian Petroleum. London: R. Anderson, 1886.

Marvin, C. Baku: The Petrolia of Europe. London: R. Anderson, 1884.

Marvin, C. The Petroleum of the Future. London: R. Anderson, 1883.

McIntyre, H. "The First Persian Pipe-Line.” Naft 2, no. 6 (November 1926): 10.

McKay, H. Oil: The Monarch of Motion. New York: Markets Publishing, 1919.

Measom, G. Official Illustrated Guide to the Great Eastern Railway. London: C. Griffin, 1865.

Melville, G. "Liquid Fuel For Naval and Marine Purposes." Scientific American S61 (February 1906): 25183.

Mercer, F., and W. Gaunt. Modern Publicity: Commercial Art Annual 1932. London: The Studio, 1932.

Millward, R. “Oil Treasures of Mexico.” National Geographic Magazine 19 (1908): 803805.

Mitzakis, M. The Oil Encyclopaedia. London: Chapman, 1922.

Mitzakis, J. The Russian Oil Fields and Petroleum Industry. London: Pall Mall, 1911.

Mohr, A. The Oil War. London: Martin Hopkinson, 1925.

Montague, G. "The Transport Phase of the Oil Industry." Journal of Political Economy 15, no. 8 (October 1907): 449-469.

Moore, H. Liquid Fuels for Internal Combustion Engines. London: C. Lockwood, 1920. 
Moreno, F. Petroleum in Peru, From an Industrial Point of View. Lima: F. Massias, 1891.

Morton, H. In Search of Wales. London: Methuen, 1932.

Nevett, T. Advertising in Britain: A History. London: Heinemann, 1982.

Newbold, J. The Doom of a Coalfield: 'Big Business' in South Wales. London: Communist Party of Great Britain, 1921.

Neuberger, H. Technology of Petroleum. London: Scott, Greenwood \& Co., 1901.

Norman, O. The Romance of the Gas Industry. Chicago: A.C. McClurg, 1922.

North, S. (Ed.). Britain's Fuel Problems. London: Fuel Economist, 1927.

North, S. Oil Power. London: Isaac Pitman, 1922.

North, S. Oil Fuel. London: Charles Griffin, 1911.

North, S. Petroleum: Its Power and Uses. London: Walter Scott, 1904.

Pall Mall Gazette. "Pall Mall Gazette” Guide to the Oil Companies Particulars of the Principal Oil Companies, with Alphabetical List of Directors. London: The Gazette, 1910.

Patton, J. Natural Resources of the United States. New York: Appleton, 1894.

Paul, B. On Liquid Fuel. London: Royal Society of Arts, 1868.

Peareth, H. Report on Natural Gas and Petroleum in Ontario Prior to 1891. Ottawa: Geological Survey of Canada, 1892.

Peckham, S. "The Genesis of Bitumens, as Related to Chemical Geology." Proceedings of the American Philosophical Society 37, no. 157 (January 1898): 108-139.

Peckham, S. "On the Nature and Origin of Petroleum." Proceedings of the American Philosophical Society 36, no. 154 (January 1897): 103-112.

Peckham, S. Petroleum and Its Products. Washington: Government Printing Office, 1884.

Peckham, S. "The Origin of Bitumens.” American Journal of Science 28, no. 164 (JulyDecember 1884): 107. 
Perkin, F. Text Book of Elementary Chemistry. London: Constable, 1916.

Perkin, F. "Oils, Their Production and Manufacture." Journal of the Royal Society of Arts 63 (1915): 837-848.

Perkin, F. "The Oil Resources of the Empire." Journal of the Society of Arts 62 (1914): 471-488.

Perkin, F. Practical Methods of Electro-Chemistry. London: Longmans, 1905.

Perkins, M. “Sir Boverton Redwood, Bart.” Journal of the Chemical Society 117 (January 1920): 467.

Pevsner, N. An Inquiry into Industrial Art in England. Cambridge: Cambridge University Press, 1937.

Plummer, F. “Progress in Petroleum Geology.” AAPG Bulletin 5, no. 3 (1921): 413-416.

"Poseidon." "In Bondage to Oil." Naval Review 16, no. 4 (November 1928): 769.

Pounder, C. Oil Burning Installations. London: Emmott, 1924.

Powell, F. "The Alfred Millenary of 1901.” North American Review 173, no. 539 (1901): 518-532.

Prioleau, J. Car and Country. London: J.M. Dent, 1929.

Prutzman, P. Production and Use of Petroleum in California. Sacramento: W.W. Shannon, 1904.

Rawlinson, G., et al. (Eds.). History of Herodotus. London: Murray, 1862.

Read, H. Art and Industry: The Principles of Industrial Design. London: Faber \& Faber, 1934.

Redwood, B. Petroleum Technologist's Pocket-Book. London: Charles Griffin, 1915.

Redwood, B. "The Future of Oil Fuel." Journal of the Royal Society of Arts 62 (26 December 1913): 103-116.

Redwood, B. “Petroleum.” Encyclopedia Britannica, Vol. 21 (1911): 321-333.

Redwood, B. “Turin International Exhibition 1911: The British Section.” The Lancet 177 (February 1911): 399-400. 
Redwood, B. "Report on a Sample of N'Hangellite from Inhambane, Portuguese East Africa." Bulletin of the Royal Botanic Gardens 5 (1907): 151-153.

Redwood, B. Detection and Measurement of Petroleum Vapour in the Air. London: Crosby Lockwood, 1896.

Redwood, B. Petroleum. London: Charles Griffin, 1896.

Redwood, B. Cantor Lectures on Petroleum and Its Products. London: Trounce, 1886.

Redwood, B. "The Russian Petroleum Industry." Journal of the Society of Chemical Industry 2, no. 4 (1885): 70.

Redwood, B. "International Inventions Exhibition." Journal of the Society of Arts 21 (August 1885): 966.

Redwood, B. "The Determination of the Percentage of Oil in Paraffin Scale." Journal of the Society of Chemical Industry 3, no. 8 (August 1884): 430-432.

Redwood B., and J. Thomson. Handbook on Petroleum. London: Charles Griffin, 1906.

Redwood, B., and J. Thomson. The Petroleum Lamp: Its Choice and Use. London: Charles Griffin, 1902.

Redwood, B., and J. Thomson. Handbook on Petroleum for Inspectors Under the Petroleum Acts. London: Charles Griffin, 1901.

Reinholt, O. Oildom, Its Treasures and Tragedies. Philadelphia: David McKay, 1924.

Remfry, F. "Bauxite as a Refining Agent for Petroleum Distillates." Journal of the Society of Chemical Industry 43, no. 24 (13 June 1924).

Rider S., and A. Trueman. South Wales: A Physical and Economic Geography. London: Methuen, 1929.

Roberts, G. The Most Powerful Man in the World: The Life of Sir Henri Deterding. New York: Covici \& Friede, 1938.

Roberts, J. "The Search for Oil.” Royal Society of Arts Journal 86, no. 4455 (April 1938): 488-525.

Rogers, A. "The Trend of Petrol Advertising.” Art and Industry (June 1938).

Ross, O. Air As Fuel; or Petroleum and Other Mineral Oils. London: Spon, 1874.

Ross, V. The Evolution of the Oil Industry. New York: Doubleday, 1920. 
Russell, G. Advertisement Writing. London: Ernest Benn, 1927.

Scott, W., and D. Howard. The Psychology of Advertising: A Simple Exposition of the Principles of Psychology in Their Relation to Successful Advertising. London: Pitman, 1932.

Sekon, G. A History of Great Western Railway. London: Digby, Long \& Co., 1895.

Shell Oil Company. A Petroleum Handbook. London: The Company, 1933.

Sinclair, E. Petroleum Marketing. New York: The Author, 1932.

Sinclair, U. King Coal. New York: Macmillan, 1917.

Slade, E. “Oil Supplies in War.” RUSI Journal 71, no. 481 (1926): 119-142.

Smith. E. "The Locality of Llandarcy." Transactions of the Neath Antiquarian Society 7 (1937/1939): 30-32.

Smith, P. The Shell That Hit Germany Hardest. London: Shell Marketing, 1919.

Sparrow, W. Advertising and British Art. London: John Lane, 1924.

Stanislaw, J. The History and Present Conditions of the Oil Industry in Galicia. London: Polish Press Bureau, 1921.

Stewart, C. "The Use of Petroleum as Fuel in Steamships and Locomotives." RUSI Journal 30 (1886): 927.

Stigand, I. Outlines of the Occurrence and Geology of Petroleum. London: Charles Griffin, 1925.

Swann, K. "What Do You Know About Your Gas or Oil Stove?" Woman's Health 32 (1905): 52-54.

Sykes, P. "South Persia and the Great War." Geographical Journal 58, no. 2 (August 1921): 101-116.

Talbot, F. All About Inventions and Discoveries: The Romance of Modern Scientific and Mechanical Achievements. London: Cassell, 1921.

Talbot, F. Electrical Wonders of the World. London: Cassell, 1921.

Talbot, F. All About Aircraft To-Day. London: Cassell, 1919. 
Talbot, F. All About Treasures of the Earth. London: Cassell, 1919.

Talbot, F. Submarines: Their Mechanism and Operation. London: W. Heinemann, 1915.

Talbot, F. The Oil Conquest of the World. London: Heinemann, 1914.

Tarbell, I. The History of the Standard Oil Company. London: Heineman, 1905.

Tassart, L. Exploitation du Pétrole. Paris: Dunod, 1908.

Tate, A. Petroleum and Its Products. London: J.W. Davies, 1863.

Thomas, I. Coal in the New Era. London: Putnam, 1934.

Thomas, R. The Merchandising of Petroleum Products. Des Moines: Homestead, 1929.

Thompson, A. The Petroleum Problem As Affecting British Industry. London: Chamber of Commerce, 1921.

Thompson, A. The Oil Fields of Russia. London: Crosby Lockwood, 1908.

Thorpe, T. A Dictionary of Applied Chemistry. London: Longmans, 1893.

Thwaite, B. Liquid Fuel: Its Advantages for Firing Steam Generators. London: Spon, 1887.

Tinkler, C. The Chemistry of Petroleum and Its Substitutes: A Practical Handbook. New York: D. Appleton, 1915.

Tomlinson, W. The North Eastern Railway: Its Rise and Development. London: Longman, Green, and Co., 1915.

Tower, W., and J. Robert. Petroleum: The Motive Power of the Future. London: Hodder \& Stoughton, 1912.

Thomson, J. The Petroleum Lamp. London: Charles Griffin, 1902.

Tramerye, P. de la. La Lutte Mondiale pour le Pétrole [The World-Struggle for Oil]. London: George Allen \& Unwin, 1921 [1927].

Villari, L. Fire and Sword in the Caucasus. London: T. Fisher Unwin, 1906.

Wade, C. Commercial Art as a Career. London: Pitman, 1937.

Ward, L. Forty Years of Spy. New York: Brentano, 1915. 
Watkins, H. Coal and Men: An Economic Social Study of the British and American Coalfields. London: Allen \& Unwin, 1934.

Weaver, L. British Advertising Art. London: Victoria and Albert Museum, 1924.

Weeks, J. Petroleum. Washington: Government Printing Office, 1896.

Wells, H. "Portrait of an Advertising Man." Golden Book Magazine 6 (October 1927): 519-524.

Williams-Ellis, C. Plan for Living: The Architect's Part. London: Faber and Faber, 1941.

Williams-Ellis, C. Britain and the Beast. London: Dent, 1938.

Williams-Ellis, C. The Architect. London: G. Bles, 1929.

Williams-Ellis, C. England the Octopus. Portmeirion: Golden Gragon, 1928.

Williamson, J. In a Persian Oil Field: A Study in Scientific and Industrial Development. London: Ernest Benn, 1927.

Wilson, A. "A Periplus of the Persian Gulf.” The Geographical Journal 69, no. 3 (March 1927): 235-255.

Wilson, A. "Bakhtiari Tribes." Journal of the Royal Asiatic Society 2 (March 1926): 22.

Wilson, A. "The Delta of the Shatt al "Arab and Proposals for Dredging the Bar." Geographical Journal 65, no. 3 (March 1925): 225-239.

Wilson, A. S.W. Persia: Letters and Diaries of a Young Political Officer, 1907-1914. Oxford: Oxford University Press, 1924.

Wilson, H. Liquid Fuel and How to Burn It. London: Institute of Marine Engineers, 1896.

Woehlke, W. "California's Black Gold: The Romance of the Oil Gushers." Sunset 25 (1925): 173-187.

Wood, H. The Story of the Royal Society of Arts. London: Murray, 1935.

Wright, A. The Analysis of Oils and Allied Substances. London: Crosby Lockwood, 1903.

Wyatt, H. (Ed.). Motor Transport and Empire. London: St. Clements, 1913.

Wyatt, M. Oil and Gas Prospects of the Northwest Provinces of Canada. Ottawa: Canadian Department of Mines, 1913. 
Young, S. Distillation and Principles and Processes. London: Macmillan, 1922.

Young, S. Fractional Distillation. London: Macmillan, 1903.

Zulver, C. “The Modern Tanker.” In A.E. Dunstan (Ed.), The Science of Petroleum. Oxford: Oxford University Press, 1938.

\section{$\underline{\text { II - Secondary Sources }}$}

\section{II.I - Published Materials}

Abdelrehim, N. "Oil Nationalisation and Managerial Disclosure: The Case of AngloIranian Oil Company, 1933-1951.” Blog Post. Abadan, Civilization \& Modernity. 14 March 2017.

Adelman, M. The Genie Out of the Bottle: World Oil Since 1970. Cambridge: MIT Press, 1995.

Allan, D. William Shipley: Founder of the Royal Society of Arts: A Biography with Documents. London: Hutchinson, 1968.

American Chemical Society. Joint Symposium on the Nomenclature of Hydrocarbons. Washington: The Society, 1949.

Amiralaii, C. Dispossession of the Former Anglo Iranian Oil Company. Tehran: Dehkhoda, 1978.

Anderson, J. East of Suez: A Study of Britain's Greatest Trading Enterprise. London: Hodder and Stoughton, 1969.

Arnold, G. Britain’s Oil. London: Hamilton, 1978.

Arts Council of Great Britain. Thirties: British Art and Design before the War. London: The Council, 1979.

Asteris, M. "The Rise and Decline of South Wales Coal Exports, 1870-1930." Welsh History Review 13, (1986/1987): 24-43.

Atabaki. T. "Far From Home, But at Home: Indian Migrant Workers in the Iranian Oil Industry." Studies in History 31, no. 1 (2015): 85-114.

Auty, R. Sustaining Development in Mineral Economies: The Resource Curse Thesis. London: Routledge, 1993. 
Bailey J., and E. Gough. Skewen \& District: A History. Neath: The Authors, 1998.

Ball, S. "Baldwin, Stanley, first Earl Baldwin of Bewdley (1867-1947)." In D. Cannadine (Ed.), Oxford Dictionary of National Biography. Oxford: Oxford University Press, 2004.

Bamberg, J. The History of the British Petroleum Company, Vol. 2, The Anglo-Iranian Years, 1928-1954. Cambridge: Cambridge University Press, 1994.

Barney, I. An Economic and Social Assessment of the Closure of BP Llandarcy. Swansea: University of Swansea Press, 2000.

Barney, I. "The Economic and Social Consequences of the Closure of BP Llandarcy." Contemporary Wales, 13 (2000): 138-158.

Barnicoat, J. A Concise History of Posters. London: Thames \& Hudson, 1972.

Barrett, R. "Picturing a Crude Past: Primitivism, Public Art, and Corporate Oil Promotion in the United States." in R. Barrett and D. Worden (Eds.). Oil Culture. Minneapolis: University of Minnesota Press, 2014.

Barrett, R., and D. Worden (Eds.). Oil Culture. Minneapolis: University of Minnesota Press, 2014.

Barrett, R., and D. Worden. “Oil Culture: Guest Editors' Introduction.” Journal of American Studies 46, no. 2 (2012): 269.

Bashmakov, I. "Three Laws of Energy Transitions.” Energy Policy 35, no. 7 (2007): 3583-3594.

Beaubouef, B. The Strategic Petroleum Reserve: U.S. Energy Security and Oil Politics, 1975-2005. College Station: Texas A\&M University Press, 2007.

Beaudreau, B. Energy and the Rise and Fall of Political Economy. Westport: Greenwood, 1999.

Beckett, A. When the Lights Went Out: Britain in the Seventies. London: Faber, 2009.

Beneš J., et al. "The Future of Oil: Geography versus Technology.” Working Paper 12/109, International Monetary Fund (May 2012).

Bercuson, D. Long Night of the Tankers: Hitler's War Against Caribbean Oil. Calgary: University of Calgary Press, 2014. 
Black, A. “'A Valuable Handbook of Information': The Staff Magazine in the First Half of the Twentieth Century as a Means of Information Management." In T. Weller (Ed.). Information History in the Modern World: Histories of the Information Age. Houndmills: Palgrave Macmillan, 2011.

Black, H. (Ed.). Canadian Scientists and Inventors. Markham: Pembroke, 1997.

Blair, J. The Control of Oil. New York: Pantheon, 1976.

Boase, G. "Marvin, Charles Thomas (1854-1890)." Oxford Dictionary of National Biography. London: Oxford University Press, 2006.

Bowden, J. "That's The Spirit!: ROP and the British Oil Market, 1924-39." Journal of European Economic History 17, no. 3 (Winter 1988): 641-665.

Boyer, D. "Energopower: An Introduction.” Anthropological Quarterly 8, no. 2 (2014): 309-34.

Boyer, D. "Energopolitics and the Anthropology of Energy." Anthropology Newsletter (May 2011): n.p.

Boyer, D., and I. Szeman. "The Rise of Energy Humanities." University Affairs. 2014. Retrieved from: www.universityaffairs.ca/opinion/in-my-opinion/the-rise-ofenergy-humanities.

Brew, G. "In Search of 'Equitability': Sir John Cadman, Reza Shah and the Cancellation of the D’Arcy Concession, 1928-1933.” Iranian Studies 50, no. 1 (2017): 125-148.

Brown, N. Hermes the Thief. Madison: University of Wisconsin Press, 1947.

Brown, R. “D’Arcy, William Knox.” In D. Cannadine (Ed.). Oxford Dictionary of National Biography. Oxford: Oxford University Press, 2004.

Brown, R. “Cultivating a 'Green' Image: Oil Companies and Outdoor Publicity in Britain and Europe, 1920-1936." Journal of European Economic History 22, no. 2 (Fall 1993): 355.

Bryant, M., and S. Heneage (Eds.). Dictionary of British Cartoonists and Caricaturists 1730-1980. Aldershot: Scolar, 1994.

Buchanan, I. British Olympians: A Hundred Years of Gold Medallists. London: Guinness, 1992.

Buckley, C. "Modernity, Tradition and the Design of the 'Industrial Village' of Dormanstown, 1917-1923.” Journal of Design History 23, no. 1 (2010): 21-41. 
Buell, F. "A Short History of Oil Cultures; or, the Marriage of Catastrophe and Exuberance." Journal of American Studies 46 (2012): 273-93.

Campbell, W. The Chemical Industry. London: Longman, 1971.

Canjels, R. "From Oil to Celluloid: A History of Shell Films." In J. Jonker, et al. (Eds.). A History of Royal Dutch Shell, Vol. 4. London: British Film Institute, 2010.

Carlyle, E. “Thornycroft, Sir John Isaac (1843-1928).” In D. Cannadine (Ed.). Oxford Dictionary of National Biography. Oxford: Oxford University Press, 2004.

Carment, D. “D’Arcy, William Knox, 1849-1917.” Australian Dictionary of Biography, Vol. 8. Melbourne: Melbourne University Press, 1981.

Carnegie, M. William Knox D'Arcy: Australian Gold and Persian Oil. Melbourne: Kildrummie Press, 1992.

Carson, W. The Other Price of Britain's Oil: Safety and Control in the North Sea. New Brunswick, NJ: Rutgers University Press, 1982.

Chakarova, V. Oil Supply Crises: Cooperation and Discord in the West. Lanham: Lexington, 2013.

al-Chalabi, F. Oil Policies, Oil Myths: Analysis and Memoir of an OPEC Insider. London: I.B. Tauris, 2010.

Cherry, G. "The Town Planning Movement and the Late Victorian City." Transactions of the Institute of British Geographers 4, no. 2 (1979): 306-319.

Choucri, N., et al. International Energy Futures: Petroleum Prices, Power, and Payments. Cambridge: MIT Press, 1981.

Chirnside, M. The Olympic-Class Ships. Stroud: Tempus, 2004.

Citino, N. "Suburbia and Modernization: Community Building and America's PostWorld War II Encounter with the Arab Middle East." Arab Studies Journal 14 (Spring 2006).

Clendinning, A. "Exhibiting a Nation: Canada at the British Empire Exhibition, 19241925." Social History 39, no. 77 (2006): 79-107.

Clendinning, A. "On the British Empire Exhibition, 1924-1925." BRANCH: Britain, Representation and Nineteenth-Century History. No date. Retrieved from: www.branchcollective.org/?ps_articles=anne-clendinning-on-the-british-empireexhibition-1924-25. 
Cleveland, C. (Ed.). Encyclopedia of Energy/ Amsterdam: Elsevier, 2004.

Colgan, J. Petro-Aggression: When Oil Causes War. Cambridge: Cambridge University Press, 2013.

Collins, M. "The Use of Petroleum by Late Archaic and Early Woodland Peoples in Jefferson County, Kentucky.” Journal of Field Archaeology 8, no. 1 (1981): 55-64.

Cook, G. The Discourse of Advertising. London: Routledge, 2001.

Corbett, D. The Modernity of English Art, 1914-1930. Manchester: Manchester University Press, 1997.

Corley, T. "Cargill, Sir John Traill, first baronet (1867-1954).” In D. Cannadine (Ed.). Oxford Dictionary of National Biography. Oxford: Oxford University Press, 2004.

Corley, T. "Greenway, Charles, first Baron Greenway (1857-1934).” In D. Cannadine (Ed.). Oxford Dictionary of National Biography. Oxford: Oxford University Press, 2004.

Corley, T. "Redwood, Sir (Thomas) Boverton, first baronet (1846-1919)." In David Cannadine (Ed.). Oxford Dictionary of National Biography. Oxford: Oxford University Press, 2004.

Corley, T. "Reynolds, George Bernard (1852/3-1925)." Oxford Dictionary of National Biography. Oxford: Oxford University Press, 2004.

Corley, T. History of the Burmah Oil Company, 1886-1924. London: Heinemann, 1983.

Cotton, L. "Iranian Interlude." Commercial Motorist, 18 November 1949, 43.

Cowhey, P. The Problem of Plenty: Energy and International Politics. Berkeley: University of California Press, 1985.

Crinson, M. "Imperial Modernism." In Alex Bremner (Ed.). Architecture and Urbanism in the British Empire. Oxford: Oxford University Press, 2016.

Crinson, M. "Architecture and 'National Projection' Between the Wars." In D. Arnold (Ed.), Cultural Identities and the Aesthetics of Britishness. Manchester: Manchester University Press, 2004.

Crinson, M. Modern Architecture and the End of Empire. Aldershot: Ashgate, 2003.

Crinson, M. "Abadan: Planning and Architecture Under the Anglo-Iranian Oil Company.” Planning Perspectives 12, no. 3 (1997): 341-359. 
Crinson, M. Empire Building: Victorian Architecture and Orientalism. London: Routledge, 1996.

Cronin, S. "Popular Politics, the New State and the Birth of the Iranian Working Class: The 1929 Abadan Oil Refinery Strike." Middle Eastern Studies 46, no. 5 (September 2010): 702-706.

Crosby, A. Children of the Sun: A History of Humanity's Unappeasable Appetite for Energy. New York: W.W. Norton, 2006.

Culpepper, J. “1911 Encyclopedia Britannica.” Reference Reviews 20, no. 3 (2006): 9.

Curtis, G. (Ed.). Iran: A Country Study. Washington: Library of Congress, 2008.

Damluji, M. "The Oil City in Focus: The Cinematic Spaces of Abadan in the AngloIranian Oil Company's Persian Story." Comparative Studies of South Asia, Africa and the Middle East 33 (2013): 75-88.

Damluji, M. "Documenting the Modern Oil City: Cinematic Urbanism in Anglo-Iranian's Persian Story." Ars Orientalis 42 (October 2012).

Daniels, G., and M. Rose (Eds.). Energy and Transport: Historical Perspectives on Policy Issues. Beverly Hills: Sage, 1982.

Daoudi, M., and M. Dajani. “The 1967 Oil Embargo Revisited.” Journal of Palestine Studies 13, no. 2 (1984): 65-90

Daum, A., and H. Williamson. The American Petroleum Industry: The Age of Illumination 1859-99. Westport: Greenwood, 1981.

Deese, D., and J. Nye (Eds.). Energy and Security. Cambridge: Ballinger, 1981.

Deffeys, K. When Oil Peaked. New York: Hill \& Wang, 2010.

Devanney, J. The Tank Ship Tromedy: The Impending Disasters in Tankers. Tavernier, FL: CTX Press, 2006.

Diamanti, J., and B. Bellamy. "Energy Humanities." Reviews in Cultural Theory 6, no. 3 (2016): 9 .

Diggard, J., et al. “Baktiari Tribe.” Encyclopaedia Iranica (15 December 1988): 553-560.

Divall, C. "Civilising velocity: Masculinity and the marketing of Britain's passenger trains, 1921-39." Journal of Transport History 32, no. 2 (December 2011): 164191. 
Divall, C. “Transport, 1900-1939.” In Chris Wrigley (Ed.). Companion to Early Twentieth Century Britain. London: Wiley-Blackwell, 2009.

Dixon, D. "Petrol Distribution in the U.K., 1900-1950.” Business History 6, no. 1 (1963): 7.

Dixon, D. "The Development of the Solus System of Distribution in the United Kingdom, 1950-1960.” Economica 29, no. 113 (1962): 41-52.

Dixon, D., and I. Wilkinson. The Marketing System. Melbourne: Longman Cheshire, 1989.

Doern, G., and G. Toner. The Politics of Energy: The Development and Implementation of the NEP. Toronto: Methuen, 1985.

Dougherty, C. Prometheus. London: Routledge, 2006.

Edelstein, T. Art for All: British Posters for Transport. New Haven: Yale University Press, 2010.

Ehlers, E. "Baktiari Mountains.” Encyclopedia Iranica, Vol. III. London: 1988.

Elling, R. "Abadan: Unfulfilled Promises of Oil Modernity and Revolution in Iran.” Ajam Media Collective. 26 February 2016.

Elling, R. "Abadan: Oil City Dreams and the Nostalgia for Past Futures in Iran." Ajam Media Collective. 16-26 February 2015.

Ellis-Jones, P. Oil: A Practical Guide to the Economics of World Petroleum. Cambridge: Woodhead-Faulkner, 1988.

Elwell-Sutton, L. Persian Oil. London: Lawrence \& Wishart, 1955.

Engdahl, R. "Oil and the Origins of the Great War." History Compass 5, no. 6 (2007): 2041-2060.

Engdahl, W. A Century of War: Anglo-American Oil Politics and the New World Order. London: Pluto, 2004.

Evans, M. Artwash: Big Oil and the Arts. London: Pluto, 2015.

Fantham, E. "Covering the Head at Rome: Ritual and Gender." In J. Edmondson and A. Keith (Eds.). Roman Dress and the Fabrics of Roman Culture. Toronto: University of Toronto Press, 2008.

Farber, E. Great Chemists. London: Interscience, 1961. 
Farrant, A. "Sir Waldron Smithers and the Long Walk to Finchley." Economic Affairs 32, no. 1 (January 2012): 43-47.

Fateh, M. Panjah Sal Naft-e Iran. Tehran: Sherkat-e Sahami-e Chehr, 1956.

Fatemi, N. Oil Diplomacy: Powderkeg in Iran. New York: Whittaker, 1954.

Ferrier, R. "Petrol Advertising in the Twenties and Thirties: The Case of the British Petroleum Company." European Journal of Marketing 20, no. 5 (1986): 29-51.

Ferrier, R. The History of The British Petroleum Company, Vol. 1, The Developing Years, 1901-1932. Cambridge: Cambridge University Press, 1982.

Fletcher, M. "From Coal to Oil in British Shipping." Journal of Transport History 3, no. 1 (February 1975): 3.

Fletcher, P., and A. Helmreich (Eds.). The Rise of the Modern Art Market, 1850-1939. Manchester: Manchester University Press, 2011.

Flood, C. British Posters: Advertising, Art and Activism. London: Victoria \& Albert Museum, 2012.

Floor, W. “The Early Beginnings of Modern Abadan.” Blog post. Abadan: Retold, 2017.

Foster, P. Blue-Eyed Sheiks: The Canadian Oil Establishment. Toronto: Totem, 1977.

Fouquet, R. "The Slow Search for Solutions: Lessons from Historical Energy Transitions by Sector and Service.” BC3 Working Paper Series 2010-05. Bilbao, Spain: Basque Centre for Climate Change (BC3), 2008.

Friedel, T. "(Not so) Crude Text and Images: Staging Native in 'Big Oil' Advertising." Visual Studies 23, no. 3 (2008): 238-254.

Frost, M. Street Talk: The Rise and Fall of the Poster. Victoria: Images, 2006.

Fuccaro, N. "Histories of Oil and Urban Modernity in the Middle East." Comparative Studies of South Asia, Africa and the Middle East 33 (2013): 1-6.

Fussell, G. Farming Technique from Prehistoric to Modern Times. New York: Pergamon, 1965.

Gay, H. "Technical Assistance in the World of London Science, 1850-1900." Notes and Records of the Royal Society of London 62, no. 1 (2008): 72. 
Geppert, A. Fleeting Cities: Imperial Expositions in fin-de-Siècle Europe. London: Palgrave Macmillan, 2010.

Gfeller, A. Building a European Identity: France, the United States, and the Oil Shock 1973-1974. New York: Berghahn, 2012.

Ghosn, R. "The Geographical Footprint of Urbanism: The Trans-Arabian Pipeline and its Hydrocarbon Territory." In B. De Meulder, et al. (Eds.). Urbanism and Urbanization: Transcending the Discipline. Leuven, 2009.

Giebelhaus, A., et al. (Eds.). Energy Transitions: Long-Term Perspectives. Boulder: Westview, 1981.

Gollin, A. The Impact of Air Power on the British People and Their Government, 19091914. Basingstoke: Macmillan, 1989.

Gooday, G. "Playfair, Lyon, First Baron Playfair." Oxford Dictionary of National Biography. Oxford: Oxford University Press, 2004.

Graham, E. “Outdoor Advertising.” In Printers' Ink (Ed.). Advertising: Today, Yesterday, Tomorrow. New York: McGraw Hill, 1963.

Graves, H., and D. Beard (Eds.). The Rhetoric of Oil in the Twenty-First Century: Government, Corporate and Activist Discourses. London: Routledge/TaylorFrancis, Forthcoming 2018.

Gray, D. "Carrying Canadian Troops: The Story of RMS Olympic as a First World War Troopship.” Canadian Military History 11, no. 1 (2002): 54-70.

Greenaway, F. “The Mond Family.” In D. Cannadine (Ed.). The Oxford Dictionary of National Biography. Oxford: Oxford University Press, 2004.

Green, O., and J. Reese-Davies. Designed for London: 150 Years of Transport Design. London: Laurence King, 1995.

Gressley, G. "The French, Belgians, and Dutch Come to Salt Creek." Business History Review 44, no. 4 (1970): 498-519.

Griffiths, J. Between Two Wars: Coal. London: Labour Party of Great Britain, 1942.

Griffiths, V. Llandarcy Remembered. Neath: Bryngold, 2007.

Grubler, A. "Energy Transitions Research: Insights and Cautionary Tales." Energy Policy 50 (2012): 8-16. 
Handy, L. Wages Policy in the British Coalmining Industry. Cambridge: Cambridge University Press, 1981.

Hardie, D. A History of the Modern British Chemical Industry. Oxford: Pergamon, 1966.

Harp, S. Marketing Michelin: Advertising and Cultural Identity in Twentieth-Century France. Baltimore: Johns Hopkins University Press, 2001.

Harris, R. "Hermes Iconography in Communications and Commerce: Semiotics of Cultural Networks." The Ephemerist 159 (December 2012): 6-12.

Harrison, C. English Art and Modernism, 1900-1939. New Haven: Yale University Press, 1994.

Hart, N. The Practice of Advertising. Oxford: Butterworth-Heinemann, 1995.

Harvey, W., and R. Solly. BP Tankers: A Group Fleet History. London: Chatham, 2006.

Haws, D. Merchant Fleets: Britain's Railway Steamers. Hereford: TCL, 1993.

Hendon, D., and W. Muhs. "Origin and Early Development of Outdoor Advertising in the United States.” European Journal of Marketing 20, no. 5 (1986): 7-17.

Hewitt, J. "The 'Nature' and 'Art' of Shell Advertising in the Early 1930s." Journal of Design History 5, no. 2 (1992): 126.

Hillenbrand, R. Islamic Art and Architecture. New York: Thames and Hudson, 1999.

Hirsch, E., et al. (Eds.). "Hermes." The New Dictionary of Cultural Literacy. Boston: Houghton Mifflin, 2002.

Hiro, D. Blood of the Earth: The Battle for the World's Vanishing Oil Resources. New York: Nation, 2007

Hitchcock, P. “Oil in an American Imaginary.” New Formations 69 (2010): n.p.

Holland, T. The Histories. New York: Viking, 2014.

Hoopes, S. Oil Privatization, Public Choice and International Forces. Basingstoke: Macmillan, 1997.

Houfe, S. The Dictionary of British Book Illustrators and Caricaturists 1800-1914. Suffolk: Baron, 1978.

Huber, M. Life Blood: Oil, Freedom, and the Forces of Capital. Minneapolis: University of Minnesota Press, 2013. 
Huber, M. "Energy, Environment and the Geopolitical Imagination.” Political Geography 31, no. 6 (2012).

Huber, M. "Oil, Life, and the Fetishism of Geopolitics." Capitalism Nature Socialism 22, no. 3 (2011): 32-48.

Hurt, R. The History of Agricultural Science and Technology: An International Annotated Bibliography. New York: Garland, 1994.

Hutchinson, H. The Poster: An Illustrated History from 1860. London: Studio Vista, 1968.

Ikenberry, J. "The Irony of State Strength, Comparative Responses to the Oil Shocks in the 1970s." International Organization 40, no. 1 (Winter 1986): 105-137.

Institut d'études et de recherches sociales. "Abadan: Morphologie et function du tissu urbain.” Revue Géographique de l'Est 4, no. 4 (1964): 337-385.

Jacobs, M. Panic at the Pump: The Energy Crisis and the Transformation of American Politics in the 1970s. New York: Hill \& Wang, 2016.

Jeremiah, D. "Filling up: The British Experience, 1896-1940." Journal of Design History 8, no. 2 (April 1995): 97-116.

Jones, C. Routes of Power: Energy and Modern America. Cambridge: Harvard University Press, 2014.

Jones, G. "Pearson, Weetman Dickinson, first Viscount Cowdray (1856-1927)." In D. Cannadine (Ed.). Oxford Dictionary of National Biography. Oxford: Oxford University Press, 2004.

Jones, G. The State and the Emergence of the British Oil Industry. London: Macmillan, 1981.

Jones, G. "The Oil-Fuel Market in Britain 1900-1914: A Lost Cause Revisited." Business History 20, no. 2 (July 1978): 131-152.

Jones, G. "The British Government and the Oil Companies 1912-1924: The Search for an Oil Policy.” Historical Journal 20, no. 3 (September 1977): 647-672.

Jones, G., and F. Goodall. "Redwood, Sir Thomas Boverton.” In S. Jeremy (Ed.). Dictionary of Business Biography. London: Butterworths, 1985.

Jonson, B. Carbon Nation: Fossil Fuels in the Making of American Culture. Lawrence: University Press of Kansas, 2014. 
Kapstein, E. The Insecure Alliance: Energy Crises and Western Politics since 1944. New York: Oxford University Press, 1990.

Kashani-Sabet, F. Frontier Fictions: Shaping the Iranian Nation, 1804-1946. Princeton: Princeton University Press, 1999.

Katz, J. "US Energy Policy Impact of the Reagan Administration.” Energy Policy 12, no. 2 (June 1984): 135-145.

Kazemi, F. “Anglo-Persian Oil Company.” Encyclopaedia Iranica. 15 December 1985.

Kemp, N. Abadan. London: Allan Wingate, 1953.

Kent, M. Moguls and Mandarins: Oil, Imperialism and the Middle East in British Foreign Policy, 1900-1940. London: Frank Cass, 1993.

Kent, M. Oil and Empire: British Policy and Mesopotamian Oil, 1900-1920. London: Macmillan, 1976.

Kirby, M. The History of the British Coalmining Industry, 1870-1946. London: Macmillan, 1977.

Knox, E. "Hill, Leonard Raven- (1867-1942)." In D. Cannadine (Ed.). Oxford Dictionary of National Biography. Oxford: Oxford University Press, 2004.

Knox, E. "Lucas, Edward Verrall." In D. Cannadine (Ed.). Oxford Dictionary of National Biography. London: Oxford University Press, 2004.

Krasner, S. Defending the National Interest: Raw Materials Investments and US Foreign Policy. Princeton: Princeton University Press, 1978.

Kuiken, J. "Caught in Transition: Britain's Oil Policy in the Face of Impending Crisis, 1967-1973.” Historical Social Research 39, no. 4 (2014): 272-290.

Kull-i Ārshīv, I. Oil During the Reign of Reza Shah. Tehran: Sāzmān-i Chāp va Intishārāt, 1999.

Landes, D. The Unbound Prometheus: Technological Change and Industrial Development in Western Europe from 1750 to Present. Cambridge: Cambridge University Press, 1969.

Laxer, J. Oil. Toronto: Groundwood, 2008.

Laxer, J. Canada's Energy Crisis. Toronto: James Lorimer, 1975. 
Le Billon, P. "Resources.” In K. Dodds, et al. (Eds). The Ashgate Research Companion to Critical Geopolitics. Farnham: Ashgate, 2013.

LeMenager, S. Living Oil: Petroleum Culture in the American Century. New York: Oxford University Press, 2014.

Levant, E. Ethical Oil: The Case for Canada's Oil Sands. Toronto: McClelland and Stewart, 2011.

Licklider, R. "The Power of Oil: the Arab Oil Weapon and the Netherlands, the United Kingdom, Canada, Japan, and the United States." International Studies Quarterly 32, no. 2 (1988): 205-226.

Lockhart, L., and R. Greaves. The Record of the British Petroleum Limited (1918-1946): Relations with the Persian (Iranian) Government. London: British Petroleum, 1968.

Logan, P. “Arthur Beeby-Thompson: Oil Pioneer.” GEOExPro 14, no. 3 (2017).

Logar, E. Invisible Oil. Berlin: Springer-Verlag, 2011.

Longhurst, H. Adventure in Oil: The Story of British Petroleum. London: Sidgwick and Jackson, 1959.

Longrigg, S. Oil in the Middle East. London: Oxford, 1954.

Louis, W., et al. (Eds.). The Oxford History of the British Empire. Vol 4: The Twentieth Century. Oxford: Oxford University Press, 1999.

Lucas, N. Energy and the European Communities. London: Europa, 1977.

Lynch, K. "Visit Britain's Landmarks: Follies on Shell Advertising Posters in the 1930s." The Follies Journal 5 (Winter 2005).

Lucier, P. Scientists and Swindlers: Consulting on Coal and Oil in America, 1820-1890. Baltimore: Johns Hopkins University Press, 2008.

MacKenzie, J. Propaganda and Empire: The Manipulation of British Public Opinion, 1880-1960. Manchester: Manchester University Press, 1984.

Madureira, N. Key Concepts in Energy. New York: Springer, 2014.

Mallon, B., and I. Buchanan. The 1908 Olympic Games: Results for All Competitors for All Events, With Commentary. Jefferson, NC: McFarland, 2009. 
Marder, A. Fear God and Dread Nought: The Correspondence of Admiral of the Fleet Lord Fisher of Kilverstone. London: Cape, 1953-1959.

Matthews, R. "Britannia and John Bull: From Birth to Maturity." Historian 62, no. 4 (2000): 799-820.

Maugeri, L. The Age of Oil: The Mythology, History, and Future of the World's Most Controversial Resource. Guilford, CT: Lyons, 2008.

Maull, H. “Oil and Influence: The Oil Weapon Examined.” Adelphi Papers 117 (1975).

Massie, R. Dreadnought: Britain, Germany, and the Coming of the Great War. New York: Random House, 1991.

May, G. Hard Oiler! The Story of Early Canadians' Quest for Oil at Home and Abroad. Toronto: Dundurn Press, 1998.

McBeth, B. British Oil Policy 1919-1939. London: Cass, 1985.

McCord, N., and B. Purdue. British History 1815-1914. Oxford: Oxford University Press, 2007.

McDougall, J. Fuels and the National Policy. Toronto: Butterworths, 1982.

McFall, L. Advertising: A Cultural Economy. London: Sage, 2004.

McIvor, A. "Industrial Relations in Britain, 1900-1939.” In C. Wrigley (Ed.). Companion to Early Twentieth Century Britain. London: Wiley-Blackwell, 2009.

McKee, F. 'Sink All the Shipping There': The Loss of Canada's Wartime Merchant Ships and Fishing Schooners. St. Catherine's: Vanwell, 2004.

McKenzie-Brown, P., et al. The Great Oil Age. Calgary: Detselig, 1993.

McQuaig, L. It's the Crude, Dude: War, Big Oil, and the Fight for the Planet. Toronto: Doubleday, 2004.

Mejcher, H. Imperial Quest for Oil: Iraq 1910-1928. London: Ithaca, 1976.

Mellini, P. "Ward, Sir Leslie (pseud. Spy), 1851-1922.” In D. Cannadine (Ed.). Oxford Dictionary of National Biography. Oxford: Oxford University Press, 2004.

Melosi, M. Coping With Abundance: Energy and Environment in Industrial America. New York: Knopf, 1985.

Mendershausen, H. Europe’s Changing Energy Relations. Santa Monica: Rand, 1976. 
Merrill, K. The Oil Crisis of 1973-1974. Boston: Bedford, 2007.

Messaris, P. Visual Persuasion: The Role of Images in Advertising. London: Sage, 1997.

Mielche, H. Lands of Aladdin. London: William Hodge, 1955.

Miller, M., and R. Church. "Motor Manufacturers." In N. Buxton and D. Aldcroft (Eds.). British Industry Between the Wars: Instability and Industrial Development, 19191939. London: Scolar, 1979.

Miller, R. "Small Business in the Peruvian Oil Industry: Lobitos Oilfields Limited before 1934.” Business History Review 56, no. 3 (1982): 403.

Mineau, W. The Go Devils. London: Cassell, 1958.

Minnis, J. "A Lost Elysium? The motor car and England in the inter-war years." Local Historian 44, no. 4 (2014): 266-276.

Mitchell, T. Carbon Democracy: Political Power in the Age of Oil. London: Verso, 2011.

Mitzman, A. Prometheus Revisited. Boston: University of Massachusetts Press, 2003.

Moore, T., and J. Philip. The Chemical Society, 1841-1941. London: The Chemical Society, 1947.

More, C. Black Gold: Britain and Oil in the Twentieth Century. London: Continuum, 2009.

Morgan, K. "Welsh Nationalism: The Historical Background." Journal of Contemporary History 6, no. 1 (1971): 153-172.

Morrison, K., and J. Minnis. Carscapes: The Motor Car, Architecture and Landscape in England. New Haven: Yale University Press, 2012.

Morton, M. Empires and Anarchies: History of Oil in the Middle East. London: Reaktion, 2017.

Mosley, C. Burke's Peerage and Baronetage, Vol. II. London: Fitzroy Dearborn, 1999.

Naficy, H. A Social History of Iranian Cinema, Vol. 1. Durham: Durham University Press, 2011.

Nasr, S. Islamic Art and Spirituality. Albany: State University of New York Press, 1987. 
Netschert, B., and S. Shurr. Energy in the American Economy 1850-1975. Baltimore: Johns Hopkins, 1960.

Nevett, T. Advertising in Britain: A History. London: Heinemann, 1982.

Nicholson, T. "Road Maps and Advertising in Britain, 1860-1940." Cartographic Journal 45, no. 1 (February 2008): 43.

Nikiforuk, A. The Energy of Slaves: Oil and the New Servitude. Vancouver: David Suzuki Foundation, 2012.

Nock, O. Great Western Railway in the Twentieth Century. London: George Allan, 1964.

Nouschi, A. Pétrole et rélations internationales de 1945 à nos jours. Paris: Armand Colin, 1999.

O'Connell, S. The Car in British Society: Class, Gender and Motoring 1896-1939. Manchester: Manchester University Press, 1998.

Odell, P., and K. Rosing. The Future of Oil: World Resources and Use. London: Kogan Page, 1983.

Olien, D., and R. Olien. Oil in Texas: The Gusher Age 1895-1945. Austin: University of Texas Press, 2002.

Owen, E. Trek of the Oil Finders. Oklahoma: American Association of Petroleum Geologists, 1975.

Paine, C., and E. Shoenberger. "Iranian Nationalism and the Great Powers." MERIP Reports 37 (May 1975): 3-28.

Palmeri, F. "The Cartoon: the image as critique." In Sarah Barber and Corinna PenistonBird (Eds.). History Beyond the Text. London: Routledge, 2009.

Parra, F. Oil Politics: A Modern History of Petroleum. London: I.B. Tauris, 2004.

Partanen, R., et al. The World After Cheap Oil. New York: Routledge, 2015.

Paterson, M., and S. Dalby. "Empire's Ecological Tyreprints." Environmental Politics 15 (2006): 2-3.

Petrocultures Research Group. After Oil. Edmonton: The Group, 2016.

Peyton-Smith, D. Oil: A Study of War-Time Policy and Administration. London: Her Majesty's Stationary Office, 1971. 
Podobnik, B. Global Energy Shifts: Fostering Sustainability in a Turbulent Age. Philadelphia: Temple University Press, 2006.

Podobnik, B. Transforming Globalization: Challenges and Opportunities in the Post 9/11 Era. Chicago: Haymarket, 2005.

Podobnik, B. "Toward a Sustainable Energy Regime: A Long-Wave Interpretation of Global Energy Shifts." Technological Forecasting and Social Change 62 (1999): $155-172$.

Prager, A. The Mahogany Tree: An Informal History of Punch. New York: Hawthorn, 1979.

Pratt, J. Exxon: Transforming Energy, 1973-2005. Austin: University of Texas Press, 2013.

Pratt, J. "The Petroleum Industry in Transition: Antitrust and the Decline of Monopoly Control in Oil." Journal of Economic History 40, no. 4 (1980): 815-837.

Presbry, F. The History and Development of Advertising. New York: Greenwood, 1968.

Prest, A. Consumers' Expenditure in the United Kingdom, 1900-1919. Cambridge: Cambridge University Press, 1954.

Price, R. A History of Punch. London: Collins, 1957.

Price- Smith, A. Oil, Illiberalism, and War: An Analysis of Energy and US Foreign Policy. Cambridge: MIT Press, 2015.

Quam-Wickham, N. “'Cities Sacrificed on the Altar of Oil': Popular Opposition to Oil Development in 1920s Los Angeles." Environmental History 3, no. 2 (April 1998): 189-200.

Rennie, P. Modern British Posters: Art, Design \& Communication. London: Black Dog, 2010.

Richardson, M. Sketches by Edwin Lutyens. London: Academy, 1994.

Ristow, W. "A Half Century of Oil-Company Road Maps." Surveying and Mapping 34 (December 1964): 617-637.

Ritchie, B. Portrait in Oil: An Illustrated History of BP. London: James \& James, 1995.

Rizvi, K., and S. Isendstadt (Eds.). Architecture and Politics in the Twentieth Century. Seattle: University of Washington, 2008. 
Robertons, J. Oil Slanguage: An Explanation of Terms and Slang of Oil Fields from Pennsylvania to California, Texas to Montana - and Around the World. Evansville, IN: Petroleum Publishers, 1954.

Robinson, A. (Ed.). The Scientists: An Epic of Discovery. New York: Thames \& Hudson, 2012.

Robinson, M. Marketing Big Oil: Brand Lessons from the World's Largest Companies. London: Palgrave, 2016.

Rohani, F. Tarikh-e Melli Shodan-e San'at-e Naft-e Iran. Tehran: Jibi, 1973.

Ross, H. “Dewar, Sir James (1842-1923)." In D. Cannadine (Ed.). Oxford Dictionary of National Biography. London: Oxford University Press, 2004.

Royal Society of Chemistry. Chemistry, Society and Environment: A New History of the British Chemical Industry. Cambridge: The Society, 2000.

Sa'adat, F. Pajouheshi dar Masa'el-e Nafti-e Iran (An Investigation into Iran's Petroleum Issues). Tehran: Amir Kabir, 1976.

Sabin, P. Crude Politics: The California Oil Market, 1900-1940. Berkeley: University of California Press, 2004.

Sandbrook, D. State of Emergency: The Way We Were, Britain, 1970-1974. London: Penguin, 2011.

Sandwell, R. Powering Up Canada: The History of Power, Fuel, and Energy from 1600. Montreal/Kingston: McGill-Queen's University Press, 2016.

Sauder, D. "A Glorious Half Century of Outdoor Advertising." Sign of the Times 143, no. 1 (May 1956): 112.

Seccombe, I., and R. Lawless. Work Camps and Company Towns: Settlement Patters and the Gulf Oil Industry, Occasional Paper 36. Durham: Centre for Middle Eastern and Islamic Studies, 1987.

Shaffer, E. The United States and the Control of World Oil. New York: St. Martin's Press, 1983.

Shahnavaz, S. Britain and the Opening up of South-West Persia, 1880-1914. London: Routledge, 2005.

Sheldon, C. A History of Poster Advertising. London: Chapman \& Hall, 1937. 
Sheppard, M. Oil Sands Scientist: The Letters of Karl A. Clark, 1920-1949. Edmonton: University of Alberta Press, 1989.

Sheppard, T., and J. Hoole (Eds.). That's Shell - That Is. London: Barbican Art Gallery, 1983.

Sinclair, P. Energy in Canada. Don Mills: Oxford University Press, 2011.

Slinn, J. "Morson, Thomas (1825-1908)." In D. Cannadine (Ed.). Oxford Dictionary of National Biography. Oxford: Oxford University Press, 2004.

Smil, V. Energy Transitions: History, Requirements, Prospects. Westport: Praeger, 2010.

Smil, V. Oil: A Beginner's Guide. Oxford: Oneworld Publications, 2008.

Smith, D. “Tonypandy 1910: Definitions of Community." Past \& Present 87 (May 1980): 158-184.

Smith, F. "Chemicals from Petroleum." Journal of the Society of Arts 93 (October 1945): 565.

Solberg, C. Oil Power. New York: New American Library, 1976.

Sorenson, R. " $19^{\text {th }}$ Century Russian Petroleum from Baku." Oil Industry History 1, no. 15 (2014).

Sorkhabi, R. "A History of Petroleum Geoscience Textbooks." Oil Industry History 16, no. 1 (2015): 165-208.

Sorkhabi, R. "Early Textbooks of Petroleum Geology." GEOExPro 8, no. 6 (2012).

Sorkhabi, R. "George Bernard Reynolds: A Forgotten Pioneer of Oil Discoveries in Persia and Venezuela." Oil Industry History 11, no. 1 (2010).

Steele, R. "Abel, Sir Frederick Augustus, first baronet." In D. Cannadine (Ed.). Oxford Dictionary of National Biography. London: Oxford University Press, 2004.

Stevens, J., and S. Wilson (Eds.). Oxford Dictionary of Architecture, $3^{\text {rd }}$ ed. Oxford: Oxford University Press, 2015.

Stoekl, A. "Foreword." In R. Barrett and D. Worden (Eds.). Oil Culture. Minneapolis: University of Minnesota Press, 2014.

Stoekl, A. Bataille's Peak: Energy, Religion, and Postsustainability. Minneapolis: University of Minnesota Press, 2007. 
Strauss, S., et al. (Eds.). Cultures of Energy: Power, Practices, Technologies. Walnut Creek, CA: Left Coast Press, 2013.

Streck, M. “Karun River.” Encyclopedia Iranica 4 (1978): 673-676.

Supple, B. The History of the British Coal Industry, Vol. 4, 1913-1946: The Political Economy of Decline. Oxford: Clarendon, 1988.

Swanson, E. A Century of Oil and Gas in Books. New York: Appleton, 1960.

Swinford, D. "The Muqarnas: A Key Component of Islamic Architecture.” In N. Schlager and J. Lauer (Eds.). Science and Its Times, Vol. 2. Gale Virtual Reference Library, 2001.

Szeman, I. "On the Energy Humanities: Contributions from the Humanities, Social Sciences, and Arts to Understanding Energy Transition and Energy Impasse." SSHRC Knowledge Synthesis Grant (KSG), Energy and Natural Resources. May 2016.

Szeman, I. "How to Know About Oil: Energy Epistemologies and Political Futures." Journal of Canadian Studies 47 (2013): 145-68.

Szeman, I. "Crude Aesthetics: The Politics of Oil Documentaries." Journal of American Studies 46 (2012): 423-439.

Szeman, I., and D. Boyer (Eds.). Energy Humanities: An Anthology. Baltimore: Johns Hopkins, 2017.

Szeman, I., and M. Whiteman. "Oil Imag(e)ries: Critical Realism and the Oil Sands." Imaginations 3, no. 2 (2012).

Takach, G. "Selling Nature in a Resource-Based Economy: Romantic/Extractive Gazes and Alberta's Bituminous Sands." Environmental Communication 7, no. 2 (2013): 211-230.

Taylor, J. "Written in the Skies: Advertising, Technology, and Modernity in Britain since 1885." Journal of British Studies 55, no. 4 (October 2016): 750-780.

Taylor, L., and R. Scott. "Seating Space in the Roman Senate and the Senatores Pedarii." Transactions and Proceedings of the American Philological Association 100 (1969): 529-582.

Tabrizian, P. "From City-Hills to Metropolis: The Origins and Dilemmas of Landscape Urbanism in Iran." N-Aerus XI (2014). 
Tertzakian, P., and K. Hollihan. The End of Energy Obesity: Breaking Today's Energy Addiction for a Prosperous and Secure Tomorrow. Hoboken: John Wiley, 2009.

Michael, T. The Death of an Industry: South Wales Mining and its Decline - The Local Story in a Global Context. Singapore: Colben Systems, 2004.

Tickner, L. Modern Life \& Modern Subjects: British Art in the Early Twentieth Century. New Haven: Yale University Press, 2000.

Torrens, H. “Cadman, John, first Baron Cadman (1877-1941)." In D. Cannadine (Ed.). Oxford Dictionary of National Biography. Oxford: Oxford University Press, 2004.

Torrens, H. "Craig, Edward Hubert Cunningham- (1874-1946)." In D. Cannadine (Ed.). Oxford Dictionary of National Biography. Oxford: Oxford University Press, 2004.

Türk, H. "Energy Cooperation Among Western Industrialized Countries." Historical Social Research 39, no. 4 (2014): 209-213.

Unger, R., and J. Thistle. Energy Consumption in Canada in the $19^{\text {th }}$ and $20^{\text {th }}$ Centuries. Naples: Consiglio Nazionale della Ricerche, 2013.

Urry, J. Societies Beyond Oil: Oil Dregs and Social Futures. London: Zedbooks, 2013.

Varcoe, I. "Scientists, Government and Organised Research in Great Britain 1914-16: The Early History of the DSIR." Minerva 8, no. 1 (1970): 192-216.

Ven, D. van de, and R. Fouquet. "Historical Energy Price Shocks and their Changing Effects on the Economy." Energy Economics 62 (2017): 204-216.

Venn, F. The Oil Crisis. London: Longman, 2002.

Vernon, R. The Oil Crisis. New York: Norton, 1976.

Walonen, M. “'The Black and Cruel Demon' and Its Transformation of Space: Toward a Comparative Study of the World Literature of Oil and Place." Interdisciplinary Literary Studies 14, no. 1 (2012): 56-78.

Walters, R. "Capital Formation in the South Wales Coal Industry, 1840-1914." Welsh History Review 10 (1980/1981): 68-92.

Warde, P. Energy Consumption in England and Wales, 1560-2000. Rome: Consiglio Nazionale delle Ricerche, 2007.

Warner, M. Monuments \& Maidens: The Allegory of the Female Form. London: Weidenfeld and Nicolson, 1985. 
Waverman, L. The Regulation of the Canadian Downstream Oil Industry: Nature, Impact and Remedies. Toronto: University of Toronto Press, 1985.

Weill, A. Graphics: A Century of Poster and Advertising Design. London: Thames and Hudson, 2004.

Weill, A., et al. (Eds.). Masters of the Poster, 1896-1900. London: Academy Editions, 1978.

Wenzel, J. "How to Read for Oil.” Resilience 1, no. 2 (2014).

Wenzel, J. "Petro-Magic-Realism: Toward a Political Ecology of Nigerian Literature." Postcolonial Studies 9, no. 4 (2006): 449-464.

Wereley, I. "Extracting the Past from the Present: Exotic Prizes, Empty Wilderness, and Commercial Conquest in Two Oil Company Advertisements, 1925-2012." Humanities 5, 44 (2016): 1-22.

Whiffen, D. The Royal Society of Chemistry: The First 150 Years. London: The Society, 1991.

Whiteley, N. "Modern Architecture, Heritage and Englishness." Architectural History 38 (1995): 220-237.

Wilkins, M. "The Free-Standing Company, 1870-1914: An Important Type of British Foreign Direct Investment.” Economic History Review 41, no. 2 (May 1988): 273.

Williams, C. “'Our War History in Cartoons is Unique': J.M. Staniforth, British Public Opinion, and the South African War, 1899-1902." War in History 20, no. 4 (2013): 491-525.

Williams, C. Capitalism, Community and Conflict: The South Wales Coalfield 18981947. Cardiff: University of Wales Press, 1998.

Wilson, R. “"Tommifying' the Western Front, 1914-1918.” Journal of Historical Geography 37, no. 3 (July 2011): 338-347.

Wilt, A. Food for War: Agriculture and Rearmament in Britain Before the Second World War. Oxford: Oxford University Press, 2001.

Winegard, T. The First World Oil War. Toronto: University of Toronto Press, 2016.

Wrigley, C. (Ed.). Companion to Early Twentieth Century Britain. London: WileyBlackwell, 2009. 
Yates, E. “The Evolution of the English Village." Geographical Journal 148, no. 2 (July 1982): 182-202.

Yergin, D. The Quest: Energy, Security, and the Remaking of the Modern World. New York: Baker \& Taylor, 2012.

Yergin, D. The Prize: The Epic Quest for Oil, Money and Power. New York: Simon and Shuster, 1991.

Yergin, D., and M. Hillenbrand (Eds.). Global Insecurity: A Strategy for Energy and Economic Renewal. Boston: Houghton Mifflin, 1982.

Yona, S. "What About Hermes? A Reconsideration of the Myth of Prometheus in Plato's Protagoras." Classical World 108, no. 3 (Spring 2015): 366-368.

Yorke, D., and J. Margolies. Hitting the Road: The Art of the American Road Map. San Francisco: Chronicle, 1996.

Zagagi, N. "Urban Area and Hinterland: The Case of Abadan (1910-1946)." Journal of the Middle East and Africa 7, no. 1 (2016): 61-83.

Zoghi, I. Masael-e Siasi-Eqtesadi-e Naft-e Iran. Tehran: Pazhang, 1991.

\section{II.II - Film}

Anglo-Persian Oil Company. Persia and the Oilfields. 1:48 minutes. BP Video Library. 1952.

Anlgo-Persian Oil Company. In the Land of the Shah. 28:14 minutes. BP Video Library. 1926.

Anglo-Persian Oil Company. The Oil Industry of Burmah. 32:41 minutes. BP Video Library. 1923.

Anglo-Persian Oil Company. Operations in South West Iran. 1:05 minutes. BP Video Library. 1921.

Anglo-Persian Oil Company. British Syndicate Strikes Oil at 1200 Feet in Masjid-iSuleiman, Iran. 2:55 minutes. Critical Past. 1908.

Anglo-Persian Oil Company. British Engineers and Geologists Strike Oil at Maydan-iNaftun in Khuzestan, Iran. 2:55 minutes. Critical Past. 1908.

Anglo-Persian Oil Company. Stock Footage: Persia. 0:35 minutes. Critical Past. 1908. 
Biemann, U. Black Sea Files. 2005.

British Petroleum. A Tower for Llandarcy. 10:42 minutes. BP Video Archives. 1951.

British Petroleum. Anglo-Persian Oil Company's Operations in Iran. 1:15 minutes. BP Video Library. 1921.

Fox, J. Gasland. 2010.

WPA Film Library. British and Persian Laborers Prospect for Oil. 4:05 minutes. No. 38654. 1900.

\section{II.III - Unpublished Materials}

Griffiths, V. National Oil Refineries, Ltd., Llandarcy Refinery, Neath, South Wales. Selfpublished memoir and photographic collection. No date. BP Archives, ARC 192464.

Jones, S. Spanning the Years. Self-published memoir and photographic collection. No date. c. 2004. BP Archives, ARC 144124; West Glamorgan Archives, D/D Z $338 / 43$.

Stradling, T. BP Memories. Swansea: The Author, 2008.

Stradling, T. The National Oil Refineries, Ltd. Llandarcy. Swansea: The Author, 2005.

\section{II.IV - Websites}

Bonnett, H. “The Camden Town Group in Context.” Tate Modern. August 2011. Retrieved from: www.tate.org.uk/art/research-publications/camden-towngroup/james-bolivar-manson-letter-to-lucien-pissarro-r1104663.

Doyle, W. "Lyon Playfair." University of Edinburgh School of Chemistry. No date. Retrieved from: www.chem.ed.ac.uk/about-us/history/professors/lyon-playfair.

Edwards, J. “A New History of Wales.” Wales Online. 2010. Retrieved from: www.walesonline.co.uk/news/wales-news/new-history-wales-dr-louise-1889456.

Ehsani, K. "Making Abadan an Oil Town: 1911-1921.” Abadan, Civilization \& Modernity. 28 April 2016. Retrieved from:

www.abadancm.com/2016/04/28/making-abadan-an-oil-town-1911-1921. 
Ehsani, K. "Boom \& Bust: Social Engineering and the Contradictions of Modernization in Khuzestan's Oil Company Towns, Abadan and Masjed-i-Soleyman."

Iranian.com. 15 February 2005.

Hanania, J., et al. "Downstream Oil and Gas Industry.” Energy Education. 2017.

Retrieved from: www.energyeducation.ca/encyclopedia.

Holland, E. "Tango Teas and Tangocitis.” Edwardian Promenade. 21 January 2014.

Retrieved from: www.edwardianpromenade.com/dance/tango-teas-and-tangocitis.

Holland, E. “Court Presentation.” Edwardian Promenade. 7 December 2007. Retrieved from: www.edwardianpromenade.com/etiquette/the-court-presentation.

Kennedy, P. “A Very Victorian Caricature: Leslie Ward \& Vanity Fair.” Illustration Chronicles: 175 Years, 175 Stories. 2016. Retrieved from:

www.illustrationchronicles.com/A-Very-Victorian-Caricature-Leslie-Ward-Vanity$\underline{\text { Fair. }}$

Petrocultures Research Unit. www.petrocultures.com.

Petrol Maps Archive. www.petrolmaps.co.uk.

Wells, B. "Prince of Petroleum Opens Tulsa Refinery." Oilpro.com. January 2016.

Retrieved from: www.oilpro.com/gallery/615/8502/prince-petroleum-opens-tulsarefinery.

Yarshater, E. "The Qajar Dynasty [1779-1924].” Encyclopaedia Iranica. 15 December 2004. Retrieved from: www.iranicaonline.org/articles/iran-ii2-islamic-period-page$\underline{5}$.

Yefimov, A. "Russian Oil in the Eyes of a Briton." Oil of Russia. 2005. Retrieved from: www.oilru.com/or/24/414.

Unattributed. "Thomas Boverton Redwood." Grace’s Guide British Industrial History. September 2016. Retrieved from:

www.gracesguide.co.uk/Thomas_Boverton_Redwood.

Unattributed. "Design of the Period House, 1920-1929." Bricks \& Brass. 2014. Retrieved from: www.bricksandbrass.co.uk/design by era/period house design 19201929.php.

Unattributed. "History of the 42-Gallon Oil Barrel." American Oil \& Gas Historical

Society. No date. Retrieved from: www.aoghs.org/transportation/history-of-the-42gallon-oil-barrel. 
Unattributed. "When Did England's First Filling Station Open?" Historic England. No date. Retrieved from: www.historicengland.org.uk/listing/what-isdesignation/heritage-highlights/englands-first-filling-station.

\section{II.V - Theses and Dissertations}

Alissa, R. "Building for Oil: Corporate Colonialism, Nationalism and Urban Modernity in Ahmadi, 1946-1992." Ph.D. Dissertation. University of California Berkeley. 2012.

Brown, M. "The Royal Navy's Fuel Supplies, 1898-1939; the Transition from Coal to Oil.” Ph.D. Dissertation. King's College, University of London. 2006.

Clarke, E. "The Special Areas Legislation with Reference to West Cumberland.” Ph.D. Dissertation, McMaster University. 1982.

Cooke, B. "Oil Men: The Twinned Lives of Arnold Wilson and Morris Young." Ph.D. Dissertation. University of East Anglia. 2012.

Edward Dobe, M. "A Long Slow Tutelage in Western Ways of Work: Industrial Education and the Containment of Nationalism in Anglo-Iranian and ARAMCO, 1923-1963.” Ph.D. Dissertation. Rutgers University. 2008.

Ehsani, K. "The Social History of Labor in the Iranian Oil Industry: The Built Environment and the Making of the Industrial Working Class, 1908-1941." Ph.D. Dissertation. Leiden University. 2014.

Ganjaei, S. "Representations of Iran in British Documentary, 1920s-2006.” Ph.D. Dissertation. University of East Anglia. 2010.

Gibson, W. "British Strategy and Oil, 1914-1923." Ph.D. Dissertation. University of Glasgow. 2012.

Kuiken, J. "Empires of Energy: Britain, British Petroleum, Shell and the Remaking of the International Oil Industry, 1957-1979.” Ph.D. Dissertation. Boston College. 2013.

Morris, S. "Mapping the Family Road Trip: the Automobile, the Family and Outdoor Recreation in Postwar British Columbia.” M.A. Thesis. University of Victoria. 2010.

Shafiee, K. "Cracking Petroleum with Politics: Anglo-Persian Oil and the SocioTechnical Transformation of Iran, 1901-1954." Ph.D. Dissertation. New York University. 2010. 
Speakman, M. "Shell's England: Corporate Patronage and English Art in the Shell Posters of the 1930s." Ph.D. Dissertation. University of Manchester. 2014.

Toprani, A. 'Oil and Grand Strategy: Great Britain and Germany, 1918-1941.” Ph.D. Dissertation. Georgetown University. 2012.

Vang, P. "Good Guys: A Cultural Semiotic Study of the Print Advertising of the Oil Industry (1900-2000).” Ph.D. Dissertation. Linköping University. 2014.

Wardleworth, D. "Building the Modern Corporation: Corporate Art Patronage in Interwar Britain.” Ph.D. Dissertation. Southampton Solent University. 2002.

Wereley, I. "Discourse of Dissent: Bernard Acworth, the British Anti-Oil Movement, and the Royal Navy's Use of Fuels, 1927-1937." MA Thesis. Carleton University. 2012. 